\title{
3. SITE 372: MENORCA RISE
}

\author{
Shipboard Scientific Party ${ }^{1}$
}

\section{SITE DATA}

Position:

Hole $372: 40^{\circ} 01.86^{\prime} \mathrm{N}, 04^{\circ} 47.79^{\prime} \mathrm{E}$

Hole $372 \mathrm{~A}: 40^{\circ} 01.90^{\prime} \mathrm{N}, 04^{\circ} 47.79^{\prime} \mathrm{E}$

Water Depth (sea level):

Hole 372: 2699 corrected meters (echo sounding)

Hole 372A: 2695 corrected meters (echo sounding)

Bottom Felt at: 2734 meters, drill pipe

Penetration:

Hole 372: 885 meters

Hole 372A: 154.5 meters

Number of Holes: 2

Number of Cores: 46 (all Site 372)

Total Core Recovered: 315.9 meters

Percentage Core Recovery: $73.3 \%$

Oldest Sediment Cored:

Depth subbottom: 885.0 meters

Nature: Mudstone

Age: Early Miocene

Basement: Not reached

Principal Results: Site 372 on the East Menorca Rise (Figure 1) penetrated four lithologic units: Unit I, Plio-Quaternary marls; Unit II, late Miocene gypsum and dolomitic marls; Unit III, early to middle Miocene marlstones to marls; Unit IV, early Miocene mudstones.

Although basement was not reached, extrapolation on the basis of sedimentation rates suggests that the earliest sediments deposited on the Menorca Rise should be earliest Miocene to Oligocene in age. The mudstones and marls of Units I, III, and IV are marine. All, except perhaps the lowest sediments, yielded benthic foraminifers indicative of deposition at mid-mesobathyal depths (generally greater than $1000 \mathrm{~m}$ ). A remarkable faunal

${ }^{1}$ Kenneth J. Hsü (Co-chief scientist), Eidg. Technisches Hochschule, Geologisches Institut, Zurich, Switzerland; Lucien Montadert (Co-chief scientist), Division Geologie, Institut Francais du Petrole, Rueil Malmaison, France; Daniel Bernoulli, Geologisch-palaontologisches Institut der Universitat Basel, Basel, Switzerland; Germaine Bizon, Bureau d'Etudes Industrielles et de Cooperation de l'Institut Francais du Petrole, Rueil Malmaison, France; Maria Cita, Instituto di Geologia, Universita degli Studi di Milano, Milano, Italy; Al Erickson, Department of Geology, University of Georgia, Athens, Georgia; Frank Fabricius, Institut fur Geologie Techn. Universitat, Munich, Germany; Robert E. Garrison, University of California, Santa Cruz, California; Robert B. Kidd, Institute of Oceanographic Sciences, Wormley, United Kingdom; Frederic Mélières, Laboratoire de Geologie Dynamique, University of Paris, Paris, France; Carla Müller, Geologisch-Paleontologisches Instutut der Johann Wolfgang Geothe-Universitat, Frankfurt, Germany (Present address: Bureau d'Etudes Industrielles et de Cooperation de L'Institut Francais du Petrole, Rueil Malmaison, France); Ramil C. Wright, Beloit College, Department of Geology, Beloit, Wisconsin (Present address: Department of Geology, The Florida State University, Tallahassee, Florida. change from normal marine mesobathyal $(>1500 \mathrm{~m}$ depth) to shallow lagoonal benthic faunas $(300-500 \mathrm{~m}$ depth) occurs at the base of Unit II. The evaporites were deposited in subaerial to restricted subaqueous environments. Conditions returned to normal marine mesobathal $(>1500 \mathrm{~m}$ depth $)$ in the early Pliocene Unit I. The structural history of the Menorca Rise is envisioned to have been somewhat similar to that established for stable continental margins in different parts of the world. Previous suggestions that the Balearic Basin owed its origin to Plio-Quaternary subsidence are discounted.

The Hole $372 \mathrm{~A}$ offset, drilled for heat-flow measurements only, showed that mean heat flow through the Balearic Basin is $2.3 \times 10^{-6} \mathrm{cal} / \mathrm{cm}^{2}$, about 1.5 times the mean global heat flux.

\section{BACKGROUND AND OBJECTIVES}

\section{Background}

Seismic reflection profiling and DSDP Leg 13 have shown the existence through the whole Balearic Basin of upper Miocene evaporites (Figure 2). Leg 13 drilling increased considerably the knowledge of this "Messinian event" and of the subsequent Pliocene to Quaternary history. Later seismic reflection investigations proved the existence of horizontal sedimentary layers below the evaporites attaining a thickness of several thousand meters.

Geophysical profiling also shows that the continuous pre-evaporitic layers and the thick Messinian salt layer are limited in their distribution to the deep basin underlying the abyssal plain province. Thus, this structural boundary is a feature much older than the late Miocene. On the edges of the salt basin the preevaporitic series tend to pinch out or are eroded in their upper parts. On the other hand, the upper evaporitic sequence overlying the thick salt layer and the Pliocene to Quaternary sediments are generally transgressive, so they overlie more or less unconformably the pre-Messinian sediments (Figure 3).

In some regions where the continental slope is very steep, for example off Provençe, Figure 3 (3), all the basinal sequences may pinch out on the continental rise and butt against the basement. In other regions, for instance the Gulf of Valencia, Figure 3 (2), and North of Corsica, a wide intermediate marginal zone can be recognized where the pre-evaporitic sediments extend beyond the edge of the deep basin and outcrop under a thin Messinian evaporite layer or directly under the Plio-Quaternary. The age of the pre-evaporitic formations in the Balearic Basin has been deduced from bore holes in the Gulfs of Valencia and Lion, from their general geologic framework, and from the dating of 

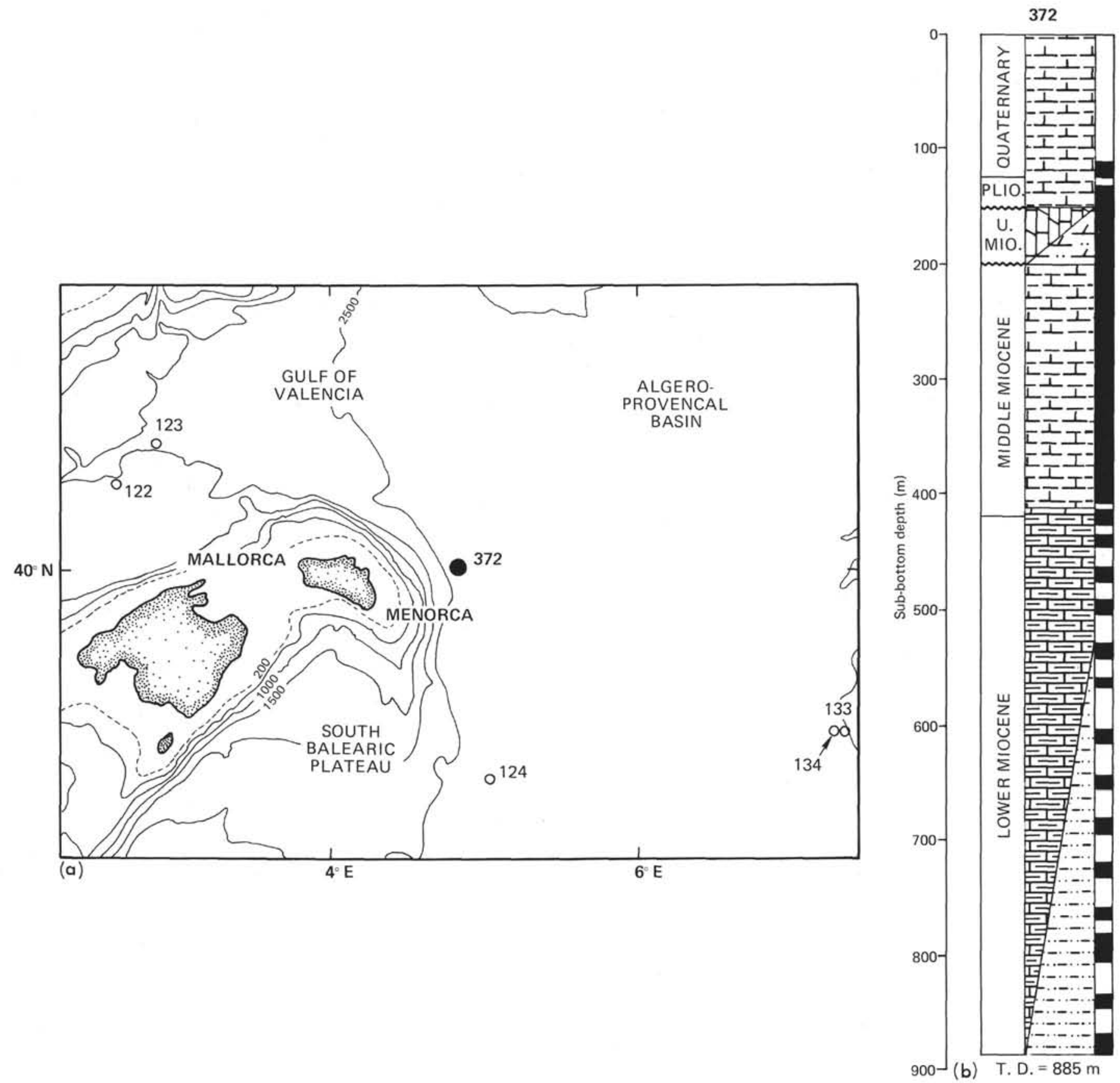

Figure 1. (A) Site location map (depth contours in meters); and (B) generalized hole summary, Site 372.

volcanic events. The age of the Algero-Provençal Basin has been suggested tentatively as Oligocene to Aquitanian (Mauffret et al., 1972) or as early to middle Miocene (Ryan, Hsü, et al., 1973). The remarkably horizontal stratification of the pre-evaporitic layers shows that they were not affected by any of the orogenic events which formed the major structures bounding this basin and which are mainly late Eocene, Oligocene, and/or middle Miocene in age.

Varying mechanisms have been suggested to explain the formation of the Algero-Provençal Basin, and reconstructions have been proposed based mainly on bathymetric and magnetic data. They include:
1) formation of a collapsed zone by rifting and thinning out of the continental crust, with almost no sea-floor spreading (oceanization model); and

2) formation of an oceanic rift associated with a counterclockwise rotation of the Corsica-Sardinia block.

\section{Objectives}

To establish by drilling the age and nature of the pre-evaporitic sediments was of great importance in assigning an age for the basin itself and thus determining its genesis and history of subsidence. The drilling was expected also to provide information on the 


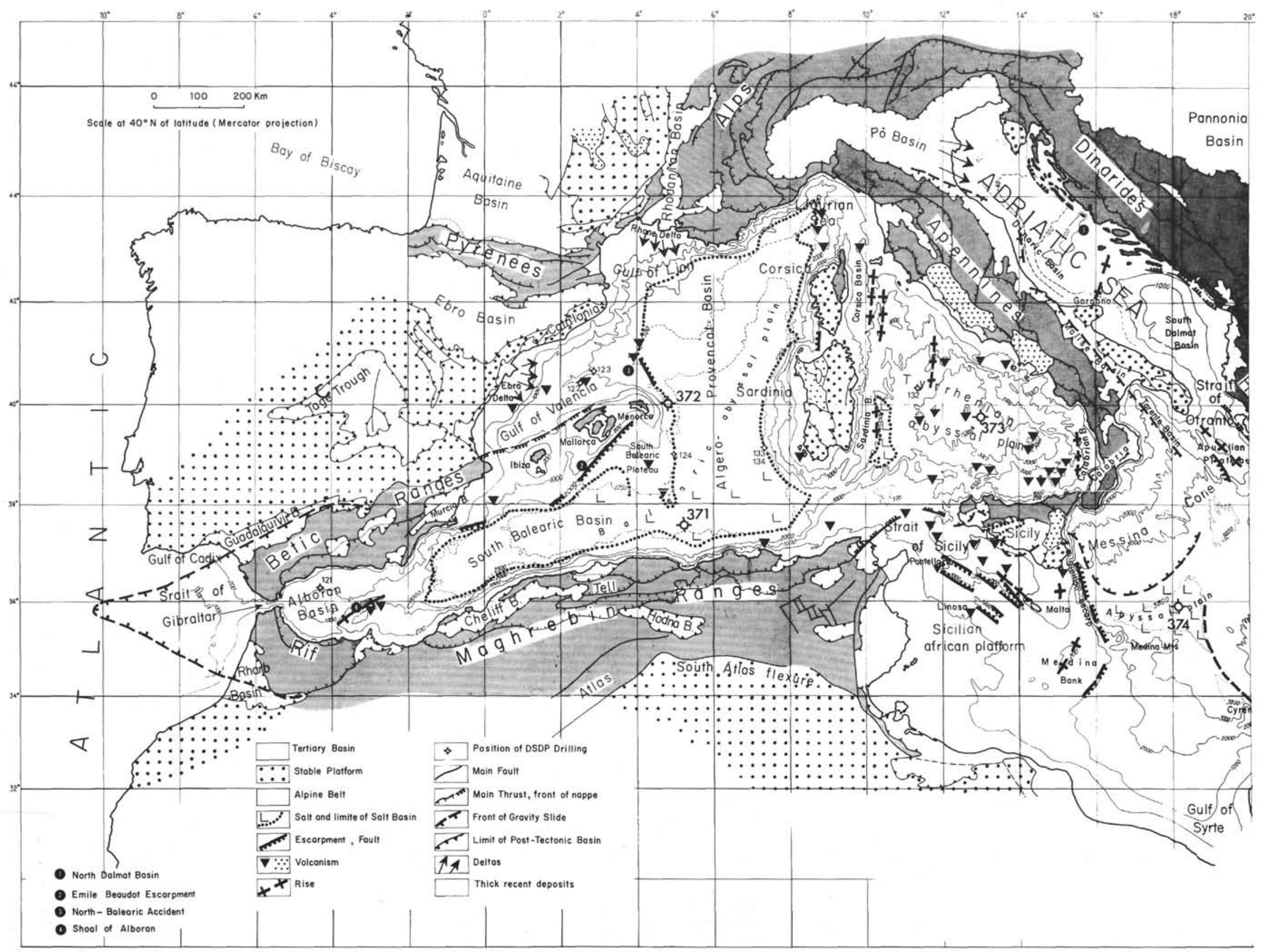



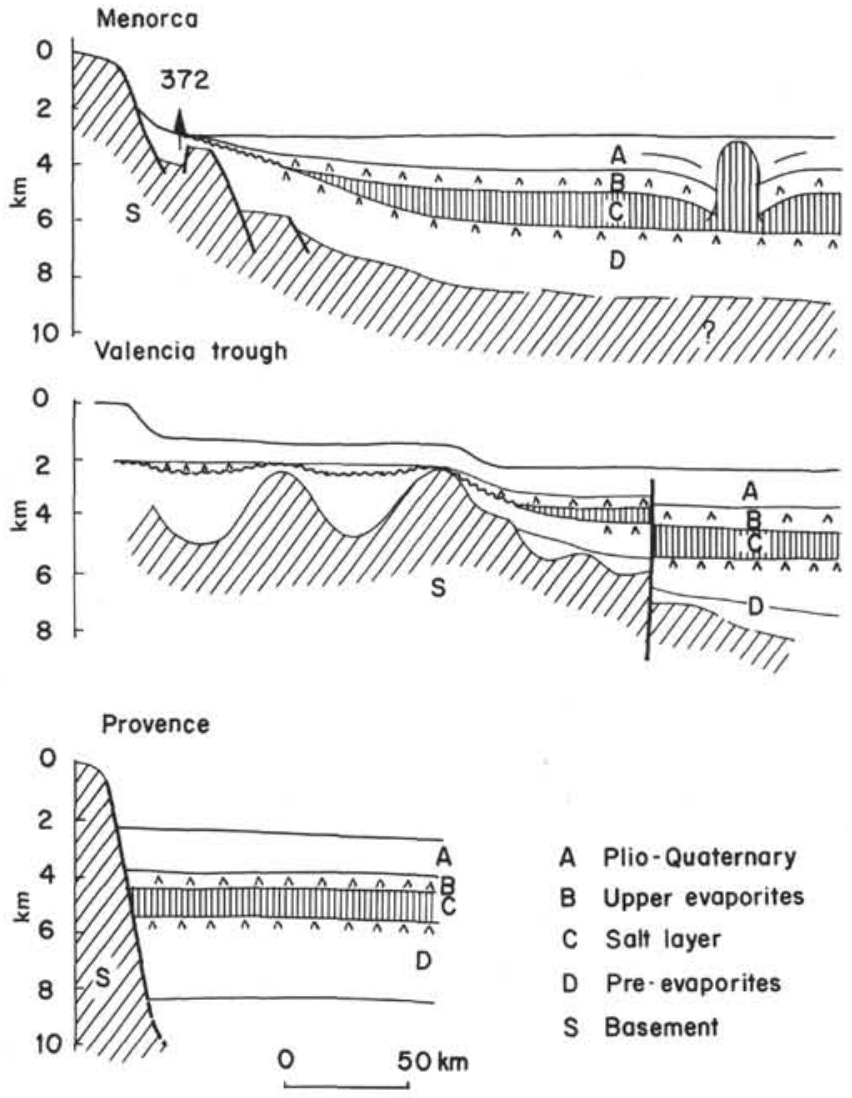

Figure 3. Three types of structural margin to the AlgeroProvençal Basin.

environment just prior to the deposition of the Messinian evaporites, thus making available new data with which to test the various models that had been proposed for their origin.

It is technically unfeasible to obtain information on pre-Messinian history from the Balearic abyssal plain province since this would involve drilling through a Pilo-Quaternary and evaporite sequence over $3 \mathrm{~km}$ thick. The salt layer and the older sediments generally pinch out on the margin at about the same location as the underlying layers. However, it was discovered during an IFP survey near Menorca that pre-Messinian sediments extend beyond the abyssal plain province and underlie directly the Pliocene-Quaternary sediments or even outcrop. Here it is possible to drill into pre-Messinian sediment without having to first penetrate a thick evaporitic sequence (Figure 4).

The choice of Site 372 was made on the basis of Institute Francais du Petrole (IFP) survey lines. In the area of the site, the margin presents some typical features of an Atlantic-type stable continental margin, with several horsts and graben filled by pre-evaporitic sediments. On the horsts the formations are much thinner and are truncated by a horizon beneath the evaporites. In the general vicinity of the proposed site along a 6 to 10 mile wide belt the pre-Messinian layers either outcrop on the sea floor or they underlie a very thin veneer of the Plio-Quaternary and Messinian sediments, as was proven by piston coring. It was thus possible to propose sites which could investigate these formations without risk of safety hazards through drilling a thick evaporite formation. Initially three holes at this site were proposed. However, time limitations induced us to drill a single deep hole with the following objectives (Figure 5):

1) to investigate the age and nature of the preevaporitic formations to provide an age for the initial rifting of the Algero-Provençal Basin and to establish its subsidence history;

2) to determine the nature of the pre-Messinian formations just below the evaporites which would detail any changes in environment just prior to the Messinian salinity crisis;

3 ) to recover sediments from the upper contact of the Messinian evaporites to provide information on their pinchout on the margin.

In addition, Hole $372 \mathrm{~A}$, an offset hole, was to be drilled 500 meters to the east in which a series of downhole temperature measurements were made to determine the rate of heat flow through the sea floor. Up to the time of this drilling, several dozen oceanographic heat-flow measurements had been made in the Mediterranean, but all had relied on temperature determinations made within 10 meters or less beneath the sea floor. Evidence of seasonal fluctuations in bottom-water temperature and of local highly variable sedimentation rates, both of which can seriously affect observed heat flow, had made interpretation of these conventional data difficult. The prime objective of Hole $372 \mathrm{~A}$ was to obtain a reliable heat-flow measurement over a subbottom interval of 100 meters or more to provide a check on earlier nearby determinations.

\section{OPERATIONS}

\section{Site Approach}

As she approached from the south, Glomar Challenger was on a $334^{\circ}$ course at 2333 LCT (18 April 1975 ) in order to follow the IFP/CNEXO profile J212. Our intention was to profile this line and to make a clover-leaf turn to the west after profile IFP J204 was crossed and on which the proposed Site 372 was situated. We could then travel from west to east on the IFP J204 until the site was reached (see Figure 6).

At 0045 LCT (19 April) the ship changed its course to the west. However, a satellite fix showed that we were further to the south than we had reckoned. It was thus decided to take again a $334^{\circ}$ course. After a further 2.5 miles and at 0105 LCT the ship began its turn to the west and by 0135 LCT the vessel was headed $060^{\circ}$, almost parallel to the IFP J204 profile. However, it appeared from the record that our course ran well to the north of the $\mathrm{J} 204$ profile. A satellite fix $(0214$ LCT) showed that we were indeed 3 miles to the north. Apparently the vessel had drifted northwards due to a strong wind from the south (up to 30 knots) $)^{\star}$ and aided perhaps by a southerly current. To maneuver the vessel back to the target site a U-turn was made at 0234 LCT. This course was continued until a satellite fix confirmed our position at 0325 LCT when the vessel changed to a $160^{\circ}$ course. At 0353 LCT, the vessel attempted its final approach on a $060^{\circ}$ 


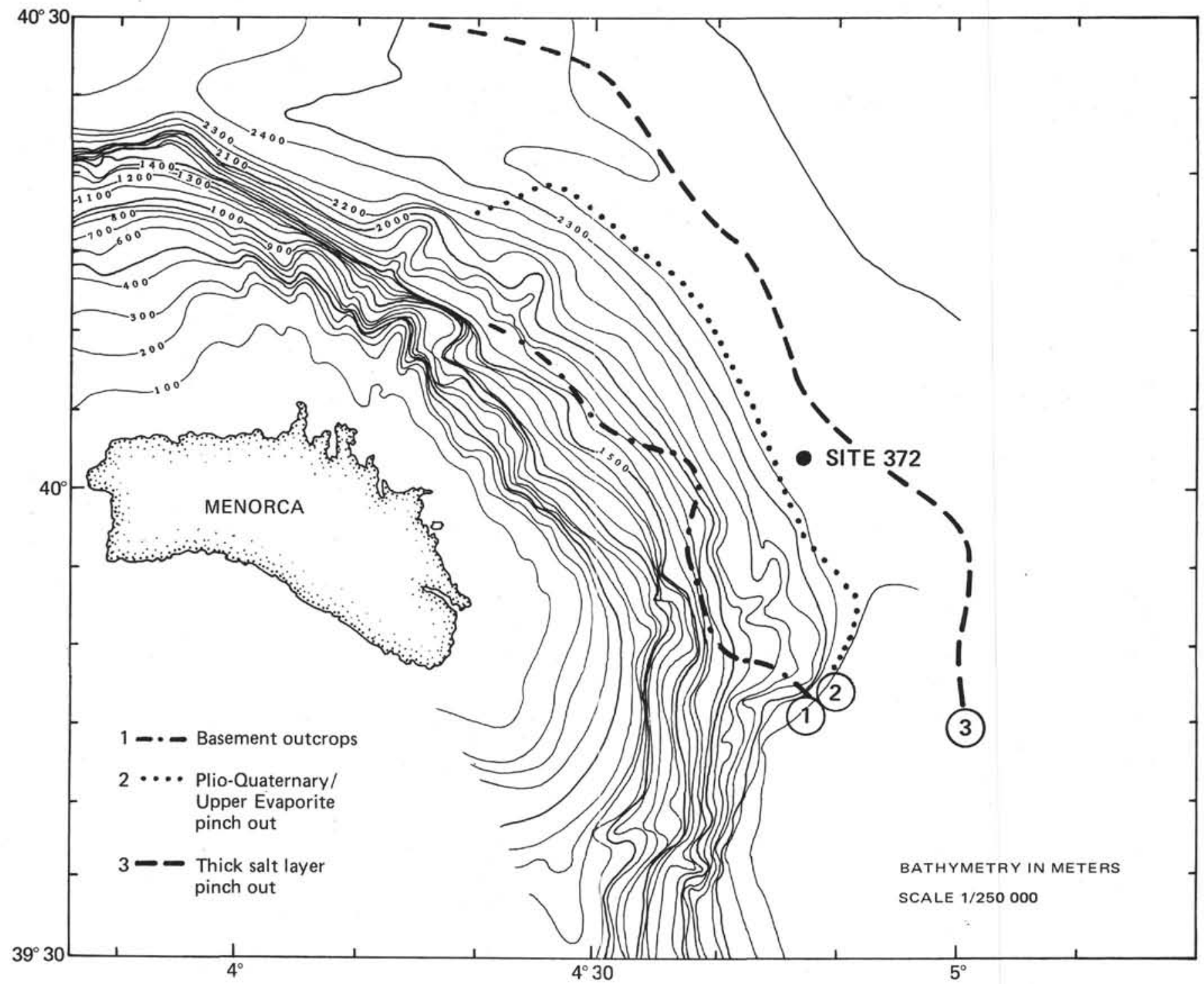

Figure 4. Geologic setting of Site 372 from IFP/CNEXO site surveys.

S. D. T.

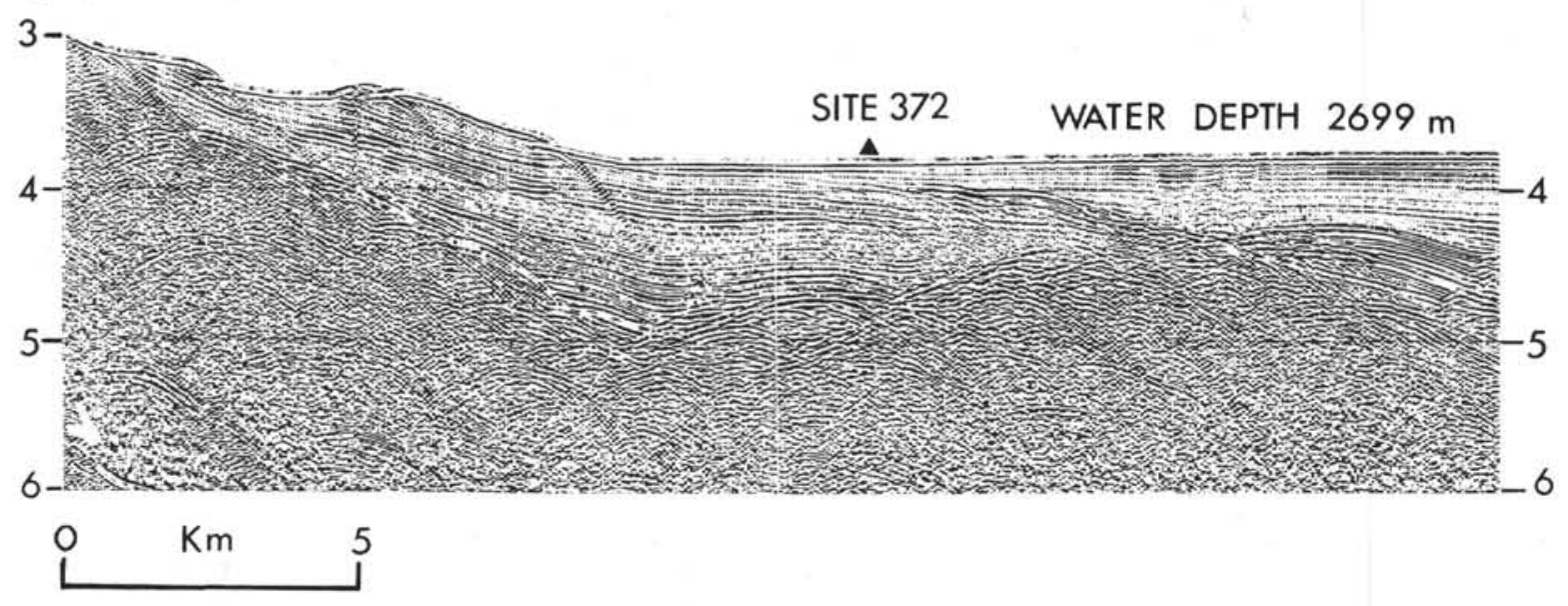

Figure 5. IFP/CNEXO profile J204 showing Site 372. 


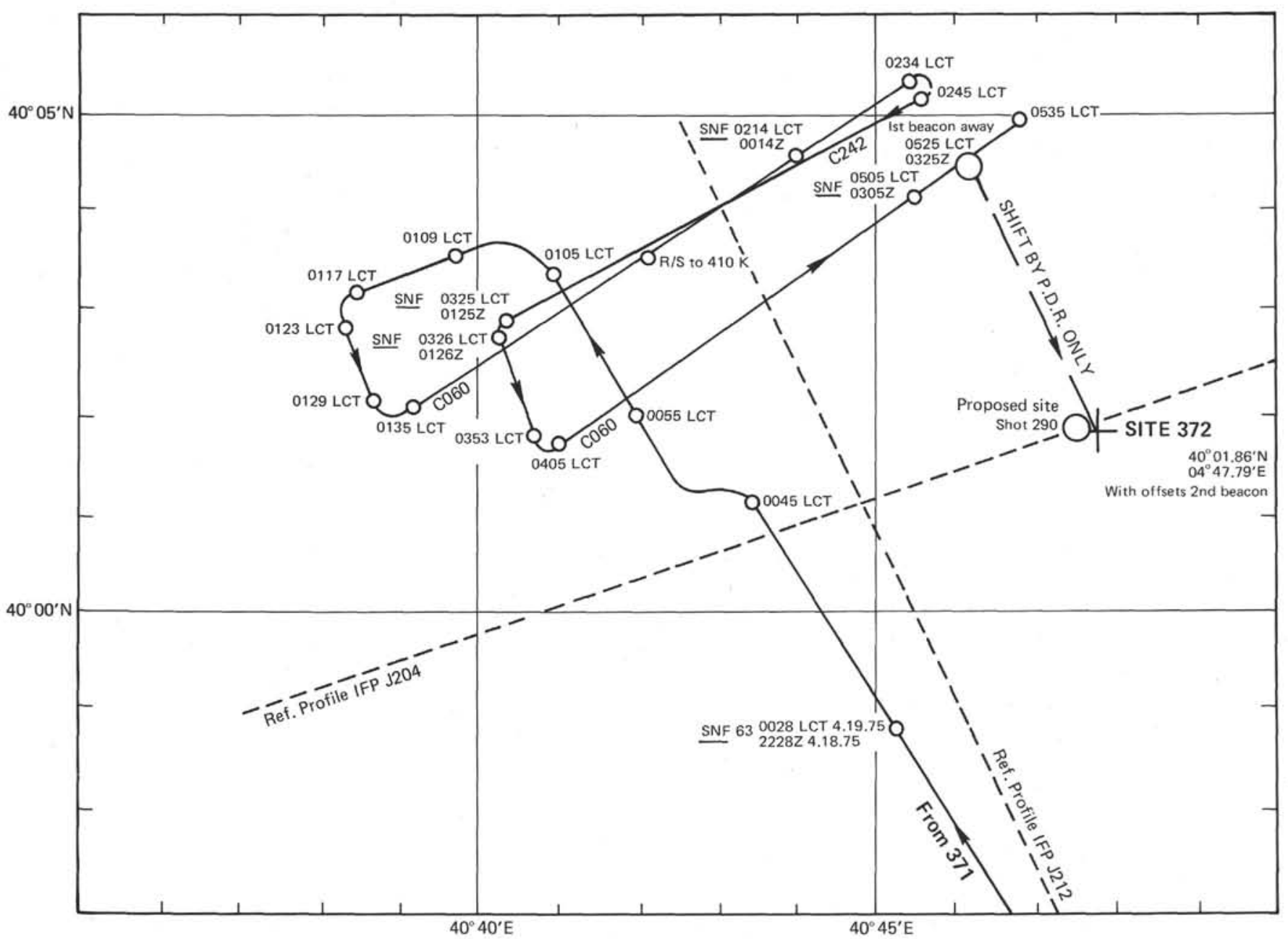

Figure 6. Site approach, Site 372.

course when we assumed we were following the J204 profile.

At 0525 the first beacon (long-life $13.5 \mathrm{kHz}$ ) was dropped and the ship commenced positioning. But the 0505 LCT satellite fix showed that again the ship was 3 miles north of the proposed site. After checking the satellite computer program, it was decided to wait for several new fixes, which eventually ascertained our position. At 0805 LCT the ship headed $150^{\circ}$ towards the proposed site at a speed of 4 knots. There a second beacon (long-life $16.0 \mathrm{kHz}$ ) was dropped at $0845 \mathrm{LCT}$. The drill crew commenced assembling the drill string at 0900 LCT. After further satellite fixes it appeared that the ship was still too far to the east of the proposed site. In order to avoid drilling through an excessively thick evaporite sequence at the site directly under the beacon, the vessel was offset by 3100 feet west-southwest from the beacon. The final location of the site was $40^{\circ} 01.86^{\prime} \mathrm{N}, 04^{\circ} 47.79^{\prime} \mathrm{E}$.

At 1500 LCT a successful sonobuoy was run giving us good indications on the depth of the different reflectors and allowing us to make a good comparison with the reference profile.

This very long approach time demonstrates that it can be very difficult under adverse conditions of wind and current to navigate Glomar Challenger to a very precise location using satellite plus dead reckoning navigation only. A continuous input of the ship's speed into the computing system would be a significant improvement. For future IPOD drillings on continental margins, more consideration must be given to the use of radio navigation aids.

\section{Drilling Program}

The drill string touched bottom at 1750 LCT, 19 April 1975 in 2734 meters water depth from the rig floor, and drilling operations were begun at 1800 LCT. After washing down 112 meters, Core 1 was taken and reached the rig floor at 2000 LCT. After washing down another 19 meters, continuous coring was begun. Between 131 meters to 406.5 meters subbottom 29 cores (Cores 2 to 30 ) were taken. Recovery in Cores 2 to 11 was incomplete, averaging only $28 \%$. Also core recovery from the Messinian evaporite was particularly poor. However, the recovery was almost $100 \%$ for the lower two-thirds of the continuously cored interval (see Table 1).

The predicted upper Miocene drill break was reached at 147 meters as Core 3 was taken. However, no evaporite was present in this core. There was 
TABLE 1

Coring Summary, Site 372

\begin{tabular}{|c|c|c|c|c|c|c|c|}
\hline Core & $\begin{array}{l}\text { Date } \\
\text { (April } \\
1975 \text { ) }\end{array}$ & Time & $\begin{array}{l}\text { Depth From } \\
\text { Drill Floor } \\
\text { (m) }\end{array}$ & $\begin{array}{l}\text { Depth Below } \\
\text { Sea Floor } \\
\text { (m) }\end{array}$ & $\begin{array}{c}\text { Cored } \\
\text { (m) }\end{array}$ & $\begin{array}{l}\text { Recovered } \\
\text { (m) }\end{array}$ & $\begin{array}{c}\text { Recovery } \\
\text { (\%) }\end{array}$ \\
\hline 1 & 19 & 2000 & $2846.0-2855.5$ & $112.0-121.5$ & 9.5 & 4.2 & 44 \\
\hline 2 & 19 & 2110 & $2865.0-2874.5$ & $131.0-140.5$ & 9.5 & 5.2 & 54 \\
\hline 3 & 19 & 2230 & $2874.5-2884.0$ & $140.5-150.0$ & 9.5 & 4.3 & 45 \\
\hline 4 & 19 & 2340 & $2884.0-2893.5$ & $150.0-159.5$ & 9.5 & 2.5 & 26 \\
\hline 5 & 20 & 0140 & $2893.5-2903.0$ & $159.5-169.0$ & 9.5 & 0.4 & 4 \\
\hline 6 & 20 & 0340 & $2903.0-2912.5$ & $169.0-178.5$ & 9.5 & 0.4 & 4 \\
\hline 7 & 20 & 0530 & $2912.5-2922.0$ & $178.5-188.0$ & 9.5 & 0.2 & 2 \\
\hline 8 & 20 & 0755 & $2922.0-2931.5$ & $188.0-197.5$ & 9.5 & 2.1 & 22 \\
\hline 9 & 20 & 0915 & $2931.5-2941.0$ & $197.5-207.0$ & 9.5 & 5.4 & 57 \\
\hline 10 & 20 & 1030 & $2941.0-2950.5$ & $207.0-216.5$ & 9.5 & 2.5 & 26 \\
\hline 11 & 20 & 1145 & $2950.5-2960.0$ & $216.5-226.0$ & 9.5 & 3.9 & 41 \\
\hline 12 & 20 & 1245 & $2960.0-2969.5$ & $226.0-235.5$ & 9.5 & 6.6 & 69 \\
\hline 13 & 20 & 1415 & $2969.5-2979.0$ & $235.5-245.0$ & 9.5 & 9.2 & 96 \\
\hline 14 & 20 & 1525 & $2979.0-2988.5$ & $245.0-254.5$ & 9.5 & 8.6 & 90 \\
\hline 15 & 20 & 1705 & $2988.5-2998.0$ & $254.5-264.0$ & 9.5 & 7.7 & 81 \\
\hline 16 & 20 & 1855 & $2998.0-3007.5$ & $264.0-273.5$ & 9.5 & 8.7 & 91 \\
\hline 17 & 20 & 2015 & $3007.5-3017.0$ & $273.5-283.0$ & 9.5 & 8.6 & 90 \\
\hline 18 & 20 & 2120 & $3017.0-3026.5$ & $283.0-292.5$ & 9.5 & 8.7 & 91 \\
\hline 19 & 20 & 2310 & $3026.5-3045.5$ & $292.5-302.0$ & 9.5 & 8.9 & 93 \\
\hline 20 & 21 & 0100 & $3036.0-3045.5$ & $302.0-311.5$ & 9.5 & 9.5 & 100 \\
\hline 21 & 21 & 0230 & $3045.5-3055.0$ & $311.5-321.0$ & 9.5 & 8.0 & 84 \\
\hline 22 & 21 & 0420 & $3055.0-3064.5$ & $321.0-330.5$ & 9.5 & 6.2 & 65 \\
\hline 23 & 21 & 0550 & $3064.5-3074.0$ & $330.5-340.0$ & 9.5 & 8.2 & 86 \\
\hline 24 & 21 & 0715 & $3074.0-3083.5$ & $340.0-349.5$ & 9.5 & 9.5 & 100 \\
\hline 25 & 21 & 0835 & $3083.5-3093.0$ & $349.5-359.0$ & 9.5 & 9.5 & 100 \\
\hline 26 & 21 & 0955 & $3093.0-3102.5$ & $359.0-368.5$ & 9.5 & 7.7 & 81 \\
\hline 27 & 21 & 1140 & $3102.5-3112.0$ & $368.5-378.0$ & 9.5 & 6.6 & 69 \\
\hline 28 & 21 & 1300 & $3112.0-3121.5$ & $378.0-387.5$ & 9.5 & 8.4 & 88 \\
\hline 29 & 21 & 1420 & $3121.5-3131.0$ & $387.5-397.0$ & 9.5 & 7.1 & 75 \\
\hline 30 & 21 & 1600 & $3131.0-3140.5$ & $397.0-406.5$ & 9.5 & 7.9 & 83 \\
\hline 31 & 21 & 1750 & $3150.0-3159.5$ & $416.0-425.5$ & 9.5 & 8.4 & 88 \\
\hline 32 & 21 & 1930 & $3169.0-3178.5$ & $435.0-445.5$ & 9.5 & 9.5 & 100 \\
\hline 33 & 21 & 2250 & $3197.5-3207.0$ & $463.5-473.0$ & 9.5 & 9.5 & 100 \\
\hline 34 & 22 & 0100 & $3226.0-3235.5$ & $492.0-501.5$ & 9.5 & 6.8 & 71 \\
\hline 35 & 22 & 0430 & $3264.0-3273.5$ & $529.0-538.5$ & 9.5 & 3.9 & 41 \\
\hline 36 & 22 & 0905 & $3302.0-3311.5$ & $568.0-577.5$ & 9.5 & 9.5 & 100 \\
\hline 37 & 22 & 1245 & $3340.0-3349.5$ & $606.0-615.5$ & 9.5 & 5.4 & 57 \\
\hline 38 & 22 & 1624 & $3378.0-3289.5$ & $644.0-653.5$ & 9.5 & 9.7 & 100 \\
\hline 39 & 22 & 2230 & $3416.0-3425.5$ & $682.0-691.5$ & 9.5 & 9.6 & 100 \\
\hline 40 & 23 & 0405 & $3454.0-3463.5$ & $720.0-729.5$ & 9.5 & 8.3 & 87 \\
\hline 41 & 23 & 1030 & $3492.0-3501.5$ & $758.0-767.5$ & 9.5 & 9.5 & 100 \\
\hline 42 & 23 & 1530 & $3520.5-3530.0$ & $786.5-796.0$ & 9.5 & 9.6 & 100 \\
\hline 43 & 23 & 1905 & $3530.0-3539.0$ & $796.0-805.5$ & 9.5 & 7.5 & 79 \\
\hline 44 & 24 & 0305 & $3568.0-3577.5$ & $834.0-843.5$ & 9.5 & 9.5 & 100 \\
\hline 45 & 24 & 1105 & $3606.0-3615.5$ & $872.0-881.5$ & 9.5 & 9.5 & 100 \\
\hline 46 & 24 & 1245 & $3615.5-3618.0$ & $881.5-885.0$ & 3.5 & 3.3 & 94 \\
\hline Total & & & & & 431.0 & 316.0 & 73.3 \\
\hline
\end{tabular}

considerable concern about the poor core recovery at 0600 LCT 20 April 1975, when the next three cores were found to contain only a few decimeters of gypsum set in marls. From a discussion with the Operations Manager and tool-pusher, it was concluded that the poor recovery was related to the nature of the formation, an alternation of hard and soft layers. At 0755 LCT Core $\uparrow$ reached the derrick floor and was found to contain 2.1 meters of laminated gypsum confirming the diagnosis that there had been no equipment problem. A drill break was encountered at 199 meters when Core 9 was cut. The drill string had apparently encountered a further marl horizon which was softer than the gypsum. Although the marls became steadily more indurated with depth, the drilling and coring times varied little. Cores 9 to 30 were retrieved at intervals ranging from 1 to 2 hours, averaging 1.4 hours per core. In order to keep the penetration rate constant, the pump-strokes were increased from 10 to $15 \mathrm{rpm}$.

After Core 30 was cut and was found to contain uppermost Burdigalian fossils (NN4,N-8), it was decided to speed up operations by spot coring. Various combinations were tried to achieve maximum rate of penetration. It seemed that the fastest formula for this type of lithology and degree of induration is to "wash 3 , core 1," namely, to drill four segments with full pump pressure, and to pull up the core barrel after the fourth pipe segment is drilled. Cores 35 to 41,44 , and 45 were taken using this schedule. Other cores were retrieved following shorter drilled intervals. 
In using these techniques, however, there is considerable uncertainty as to the true subbottom position of the cored interval. There is, for example, a strong possibility that the barrel is already full or almost full after the first pipe segment is drilled. If so the retrieved material should come largely from the top, not from the bottom, of the drilled interval. Core 33, for example, was taken after the string penetrated the 445.5 to 463.5 meter interval, and the "core-interval" was given as 463.5 to 473 meters subbottom. However, the drill string penetrated a hard layer (the second major seismic reflector) at 460 meters subbottom, that is, above the registered core interval. A piece of broken rock, which probably came from that horizon, was found in the core catcher. This suggests that the barrel was practically full even before the "cored interval" was drilled. Even more direct proof of this effect was afforded by Core 43 which was retrieved after one pipe segment $(9.5 \mathrm{~m})$ was drilled and was found to contain 7.5 meters of core. Core 42 was pulled up after two pipe segments $(19.0 \mathrm{~m})$ were drilled and it was completely full! We believe, therefore that some correction should be made to the subbottom depths of cores obtained by such coring schedules from indurated mudstones of this type.

Still another drill break was registered at 814 meters subbottom when the drill bit hit a hard formation. Some pieces of this formation were probably recovered as the hard limestone samples in the core-catcher of Core 44. A major drill break was registered at 481 meters subbottom, which also was probably represented by the limestone sample in the core catcher of Core 45. This drill break might correspond to the second major reflector on the IFP profile which had been estimated to be beneath the evaporites at $(860 \mathrm{~m}$ subbottom).

The record of drilling torque showed that it was very high at 3575-3599 meters (or 841-866 m subbottom), but that it suddenly decreased at 3599 meters subbottom. Rather than this being a further drill break, it later became clear that this represented the time when the drill cones collapsed. Drilling became very slow after Core 45 was retrieved at 1105 LCT 24 April. It was the concensus of the drilling crew and Operations Manager, that the drill bit was failing or had failed. Further penetration might lead to a closure of the bit and thus prevent the downhole heat-flow operation. At the same time, the lowest sediment reflector had been reached and we now had sufficient information to estimate the age of the basin (our last remaining objective). It was therefore decided to pull up the last core ( $3.5 \mathrm{~m}$ in length) and terminate the hole. The drill string cleared the mudline at 1435 LCT 24 April and was ready for offset to Hole $372 \mathrm{~A}$.

In Hole 372 , the total penetration was 885 meters, effected over about 4-3/4 days of drilling time. The bit proved a good choice for penetrating this type of section. Weather conditions were fairly good on the 19 and 20 April, and were excellent during the last days on site. Wind speeds reached 30 knots on these 2 days, but died to 10 knots on subsequent days. The swells ranged from 4 to 7 feet. Operations proceeded normally except for a beacon failure (long-life $13.5 \mathrm{kHz}$ ) at 0600 LCT, 22 April. A new beacon (short-life 13.5 $\mathrm{kHz}$ ) was dropped at 0640 , and the automatic mode of operation was resumed at 0720 LCT.

Hole $372 \mathrm{~A}$ was a 500 -meter offset in a $063^{\circ}$ direction, from the original hole. The offset was made to a location where the Plio-Quaternary sequence was somewhat thicker. This was to permit an optimum spacing of heat-flow measurements. The vessel was positioned over Hole 372A at 1515 LCT, 24 April, and the drill string reached bottom at 1600 LCT in 2734 meters of water. After a short delay because of rig repairs, heat-flow operations started at 1735 . No coring was done. Heat-flow measurements were made at 104.5 meters, 124.5 meters, 144.5 meters, and 155 meters subbottom. (See Erickson and Von Herzen, this volume, for details of these operations.)

Heat-flow measurements were completed at 0005 LCT, 25 April. The drill string cleared the mudline at 0035 LCT and was entirely on deck by 0430 LCT, when the vessel departed for Site 373.

\section{The Plio-Miocene Contact and Other Drill Breaks}

The first drill break in Hole 372 was at 147 meters subbottom when Core 3 (140.5-150 m) was cut. However, only 4.3 meters of Pliocene sediment were recovered, with no evaporites or other Messinian sediments. Core $4(150-159.5 \mathrm{~m})$ was believed to have been cut from an interval 3 to 12.5 meters below the top of the $\mathrm{M}$ reflector, and the recovery $(2.5 \mathrm{~m})$ was again very poor. At the top of the core is a piece of brownish-gray lower Pliocene marl, much disturbed, whereas the rest of the core is a green-gray marl of Messinian age. This occurrence suggests that the top of the upper Miocene is at -150.5 meters. Also a detailed study of the drilling penetration record shows a definite change at -150 meters which is therefore taken as the top of the evaporite formation. Several meters of sediments of unknown lithology must have been washed away and the Pliocene mud at the top of Core 4 is a downhole contaminant.

Some general observations on the lithology of the hole section between 130 and 230 meters subbottom are possible by plotting downhole the drilling rate (minutes per meter) from the drillers' record. These data can be especially helpful for the interpretation of such sections with low core recovery. Hard rock (e.g., gypsum, anhydrite, etc.) is drilled slower than less indurated sediments (e.g., marls, unconsolidated sands, etc.). In the pre-Pliocene strata, the drilling log (Figure 7) shows three pronounced maxima (long drilling time per meter): (1) between about -172 and -174 meters $(22 \mathrm{~min} / \mathrm{m}) ;(2)$ between about -179 and -182 meters $(13 \mathrm{~min} / \mathrm{m})$, and (3) between about -191 and -193 meters $(33 \mathrm{~min} / \mathrm{m})$.

There is also a minor peak at 162-163 meters ( 9 $\min / \mathrm{m}$ ). On the average the drilling rate in the Messinian is considerably higher than in the Plio-Quaternary sequence above and also in the marls below. On the basis of the drilling rates, the Messinian is believed to 


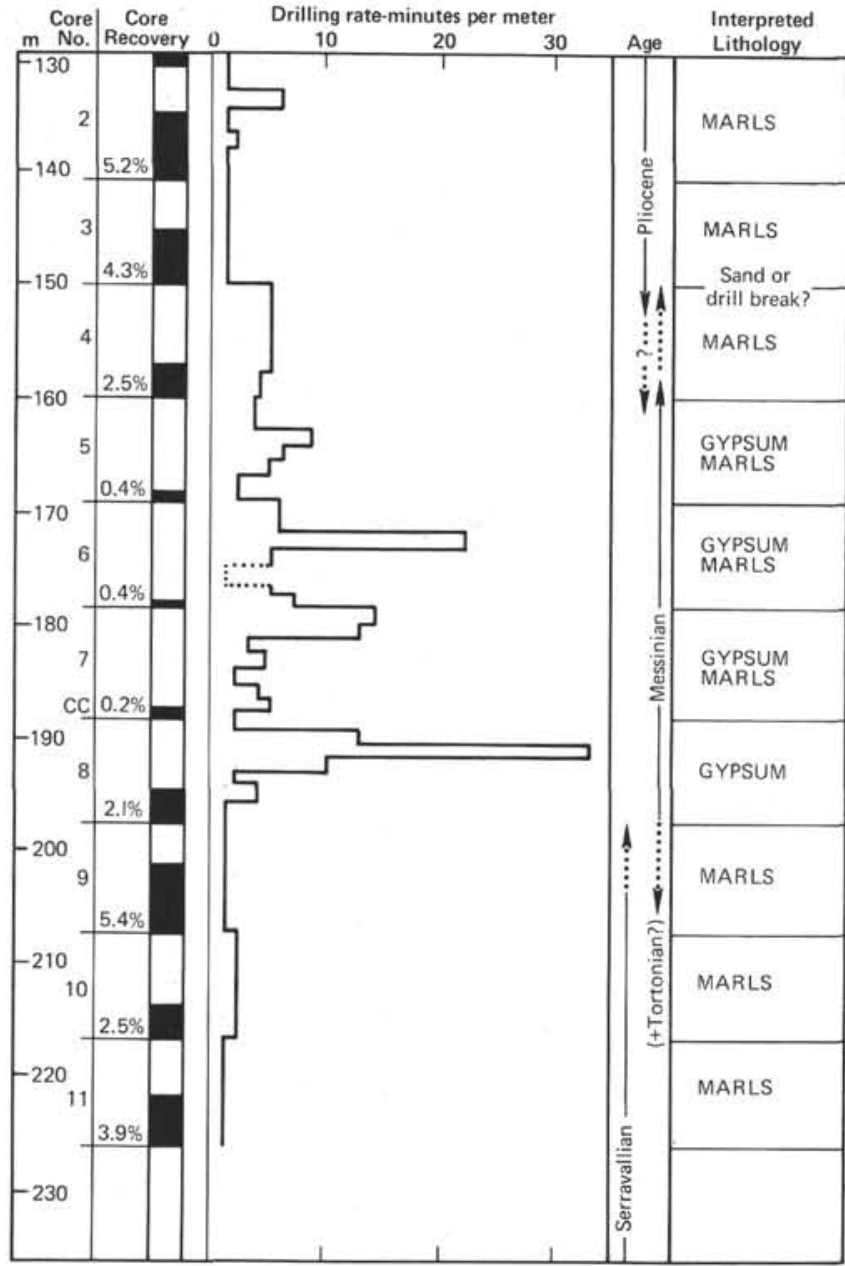

Figure 7. Interpreted Messinian lithologic sequence from drilling rates.

be about 45 meters thick and to contain at least three (to four) distinct evaporite layers.

Other important drill breaks were registered in the pre-Messinian strata at 460,814 , and 841 meters subbottom, probably corresponding to the several reflectors of the IFP and sonobuoy profiles.

\section{LITHOLOGY}

Site 372 is an 885 -meter-thick section, half of which was continuously cored and in which the sediments recovered were mainly hemipelagic marls and mudstones with some evaporites within the upper part of the section. The major lithologies are nannofossil marls and clayey mudstones with extremely low coarse terrigenous clastic content, together with gypsum and dolomitic marls in the evaporitic sequence. On the basis of shipboard observations of lithologies, the section was divided into four units as in Table 2.

\section{Unit I}

This unit consists of light gray soft nannofossil marls which become dusky yellow when foraminifer rich. The very high pelagic foraminifer content near the base of the unit (Core 3, Section 3) suggests either
TABLE 2

Lithologies at Site 372

\begin{tabular}{clcccc}
\hline Unit & Lithology & Cores & $\begin{array}{c}\text { Sub- } \\
\text { bottom } \\
\text { Depth }(\mathrm{m})\end{array}$ & $\begin{array}{c}\text { Thickness } \\
(\mathrm{m})\end{array}$ & Age \\
\hline I & $\begin{array}{l}\text { Nannofossil } \\
\text { marls }\end{array}$ & $1-3$ & $0-150$ & 150 & $\begin{array}{l}\text { Quaternary and } \\
\text { Pliocene }\end{array}$ \\
II & $\begin{array}{l}\text { Gypsum and } \\
\text { dolomitic } \\
\text { nannofossil } \\
\text { marls }\end{array}$ & $\begin{array}{l}4-9, \\
2-45 \mathrm{~cm}\end{array}$ & $150-199.5$ & 49.5 & Upper Miocene \\
III & $\begin{array}{l}\text { Nannofossil } \\
\text { marls to } \\
\text { marlstones }\end{array}$ & $\begin{array}{l}9-2,45 \\
\text { cm to 33, }\end{array}$ & $199.5-468$ & 268.5 & $\begin{array}{l}\text { Middle and low- } \\
\text { Section 3 }\end{array}$ \\
IV $\begin{array}{l}\text { Mudstones } \\
\text { to nanno- } \\
\text { fossil } \\
\text { marlstones }\end{array}$ & $\begin{array}{l}33-46, \\
\text { Section 4 }\end{array}$ & $468-885$ & 417 & Lower Miocene \\
\hline
\end{tabular}

optimal climatic conditions at the time causing increased biologic productivity, or the effects of winnowing. Discrete fine terrigenous (quartz-rich) sandy and silty layers (Cores 1 and 3), which coarsen upwards, confirm the existence of bottom current activity. The general color of the sediment, the absence of pyrite, and the faint but constant terrigenous input (clays with quartz and mica) indicate an open-sea environment. The main clay mineral is illite $(25 \%$ to $30 \%$ of the total bulk mineralogy). Dolomite percentages are low ranging between $1 \%$ and $4 \%$. A drilling break during the cutting of Core 3 and the presence of sand coating the inner wall of the Core 4 linear suggest the presence of at least one major sand layer between Cores 3 and 4 (approximately $150-155 \mathrm{~m}$ ).

\section{Unit II}

The sequence of Core 4 through Sample $9-2,45 \mathrm{~cm}$ is in marked contrast to Unit I above comprising rocks containing, or made up entirely of, evaporitic minerals. Unit II consists of two major lithologies, more or less interbedded, with a frequency which is uncertain because of poor recovery.

The three lithologies are:

1) White to dusky yellow green, hard, laminated and nodular gypsum. Laminae average $0.5 \mathrm{~cm}$ thick and display the well-known "Balatino" facies as in Core 8 . This is generally interpreted as a subaqueous deposit (Ogniben, 1957; Schreiber et al., in press);

2) Predominantly greenish-gray, soft to stiff, variably pyrite and dolomite-bearing nannofossil marls with rare or no burrowing activity; and

3) Varve-like dolomitic nannofossil marls.

The extremely poor recovery by Cores 5,6 , and 7 means that little is known of the major part of the evaporite formation, Core 8 being the only good sequence recovered $(2.5 \mathrm{~m})$. This core is made up of gypsum which is mostly laminated in parallel, fine grained, white to dusky yellow-green laminae, from 2 to $6 \mathrm{~mm}$ thick. At some levels this "Ballatino-type" lamination gives way to crenulated or cross-laminae and at the base of the core the gypsum is in the form of a slump breccia, which has been recemented. The record of drilling rate indicates the presence of several 
hard layers at 163-164 meters; 172-173.5 meters; 177.5-181.5 meters, and 191-192 meters subbottom. These are interpreted as laminated gypsum layers interbedded with the laminated, pale red to light brown gypsiferous dolomitic nannofossil marl, which was noted over a few decimeters in Cores 5, 6, and in 7 , CC. Dolomite content of this unit is on the whole greater than in underlying and overlying units, especially in Cores 5 and 6 . Smectite enters the spectrum of clay minerals below the upper Unit II boundary (Core 3 ), but the ratios of the other clay minerals change little from the Plio-Pleistocene values.

In Core 9, below a few pieces of broken gypsum and a 20-cm-thick disturbed marl zone, occur laminated and varve $^{2}$-like dolomite-bearing nannofossil marls. One-hundred $\mathrm{cm}$ below the disturbed marl zone is a sediment sequence characterized by submillimetric, very regular, dolomite-bearing nannofossil marl laminations, (Figure 8) alternately white and grayishyellow-green in color. The colors represent alternating high (gray layer) and low (white layer) contents of detrital material. In addition, the fossil content of the two types of layer varies markedly (see Biostratigraphy section). The absence of burrows or macroscopic shells suggests a lack of bottom dwelling macrofaunas at this time. The white varve laminae are generally thicker than the dark ones. Only the dark sediments form the nonlaminated intervals that appear intermittently.

Unit III sediments occur immediately below the major hiatus identified by Muller and Cita at 9-2, 50 $\mathrm{cm}$ between $9-2,45 \mathrm{~cm}$ and $9-2,57 \mathrm{~cm}$ is an interval of marl with discrete sandy layers which contain clay coated gypsum and pyrite clasts. There is no further sedimentary evidence of this hiatus which is so clear on seismic profiles. No lamination is present in the Unit 3 marls below this level, but the sediments are disturbed by core-discing as is described by Kidd, this volume.

A detailed mineralogical study of this sequence passing from Unit III to Unit II appears in Mélières (this volume).

The Core 4 nannofossil marls are generally similar to those below the gypsum deposits in mineralogy (pyrite-rich), in color (greenish-gray to variegated grayish-red, pale brown, and light brownish-gray) and in dolomite content. Also they display numerous millimetric, fine sand laminae rich in foraminifera and terrigenous material which coarsen upward and display sharp and contorted contacts with the overlying marls. These laminae in Core 4 may suggest a slight and progressive dilution of the restricted evaporitic environment by discrete incursions of seawater.

The evaporitic sedimentation that occurred at Site 372 was followed by Pliocene open-marine sedimentation.

\section{Unit III}

This unit consists of homogeneous nannofossil marls, which progressively lithify downhole to

\footnotetext{
${ }^{2}$ "Varve" is used here as sedimentary structural term and does not connotate annual layering.
}

marlstones. Color changes gradually from light bluishgray in the upper part to greenish-gray at the base. "Core discing," a feature caused by drilling in stiff lithologies, characterizes much of this sequence (Kidd, this volume). Burrowing is rare or non-existent in the uppermost part, but it increases downwards and there shows a great variety of burrow types including Zoophycos, Planolites, and Chondrites. Total carbonate content remains remarkably constant as do the clay and dolomite contents. Smectite is present as the dominant clay mineral. In the lowermost cores of Unit III ( 28 to 33$)$ zeolites are prominent.

This unit is interpreted as one of quite open-marine sedimentation, free of any coarse terrigenous input. Despite the probable proximity of land margins, there is a total lack of turbidite-type sediments.

\section{Unit IV}

In Core 33 an abrupt change in sedimentological parameters (between Section 3 and Section 4) marks the very sharp boundary between Units III and IV. From above it (Section 3 ) to below (Section 4) there is a brisk drop in carbonate content from $65 \%$ to $30 \%$, while the detrital fraction (mostly clays) rises from $25 \%$ to $60 \%$. This trend continues through the upper cores of the unit so that by Core 36 the carbonate content has dropped to below $25 \%$ and the lithology becomes mudstone through to the base of the hole. Smectite is present or abundant in Unit III but absent in Unit IV. Also opal-CT is present throughout Unit IV, but is absent in Unit III.

Colors in Unit III are predominantly dark greenishgrays. Flattened burrows demonstrate the compaction of the mudstones which are hard to very hard.

Intercalations of graded and laminated fine quartzose-calcareous sandstone to siltstone occur near and at the base of this unit (Cores 44, 45, and 46). Also present are pieces of rock representing even harder horizons in the column. A piece of partly terrigenous silty limestone occurs in Sample 44, CC. Another fine to medium grained lithic sandstone, believed to have resulted from calcareous cementation of a well-sorted terrigenous sand (quartz and rock fragments), was found in Sample 46, CC at the bottom of the hole. Dolomite, which is probably detrital, increases downhole concurrently with the increase in terrigenous material. Smectite was again identified in the lowermost cores.

The differences in lithology between Units IV and III probably reflect a difference in biogenic conditions and in turn suggest a change in oceanographic environment between the two.

\section{GEOCHEMICAL MEASUREMENTS}

\section{Interstitial Water}

Geochemical determinations made on interstitial water extracted from Site 372 sediments are listed in Table 3.

Both salinity and chlorinity (Figure 9) values show increasing trends down to a subbottom depth of about 


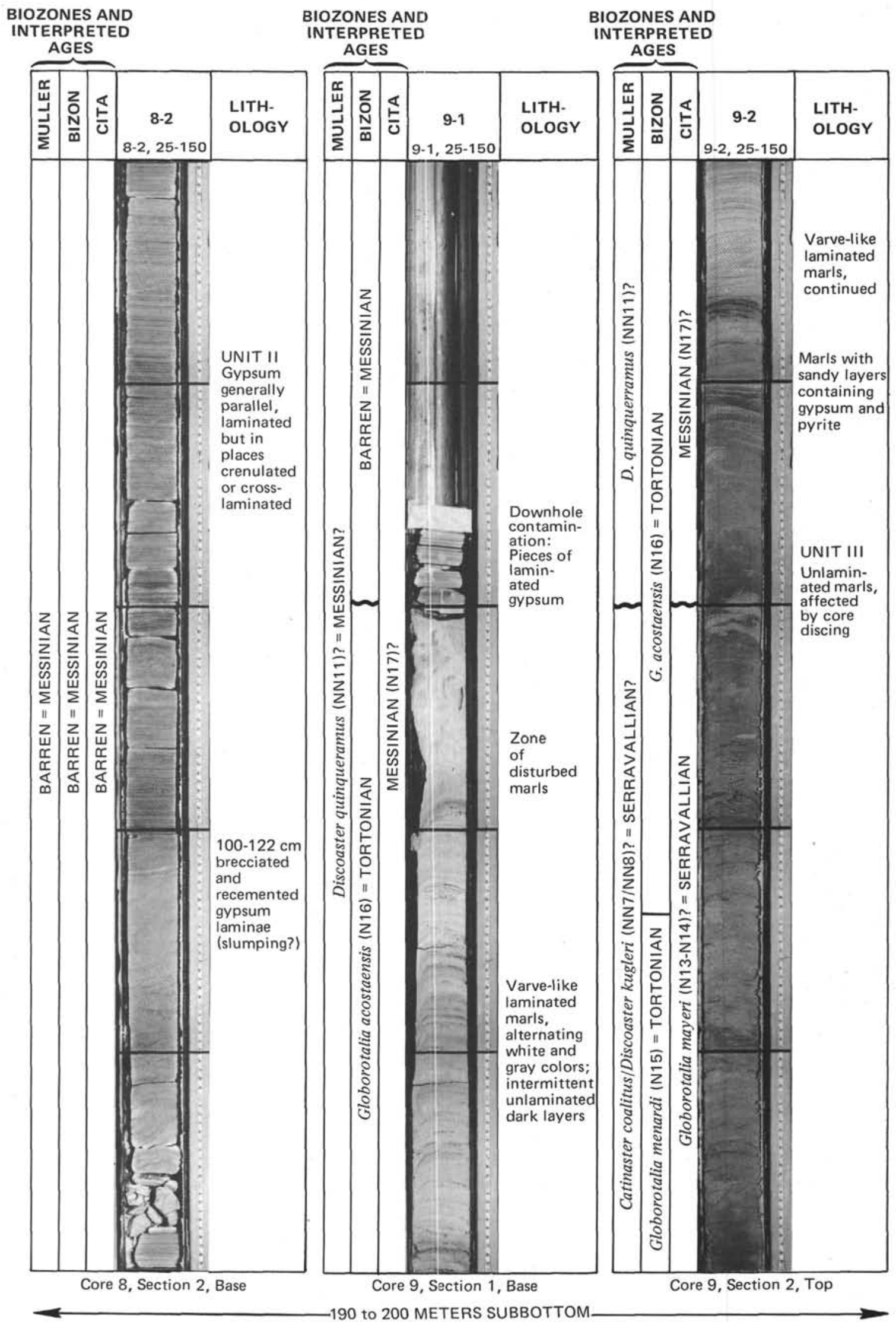

Figure 8. The sequence of sediments in cores 8 and 9, Site 372 representing the upward change from Unit 3 marls to Unit 2 evaporites. 
TABLE 3

Summary of Shipboard Geochemical Measurements, Site 372

\begin{tabular}{|c|c|c|c|c|c|c|c|c|}
\hline $\begin{array}{l}\text { Sample } \\
\text { (Interval } \\
\text { in } \mathrm{cm} \text { ) }\end{array}$ & $\begin{array}{l}\text { Depth } \\
\text { Below } \\
\text { Sea Floor } \\
\text { (m) }\end{array}$ & $p \mathrm{H}$ & $\begin{array}{l}\text { Alkalinity } \\
(\mathrm{meq} / 1)\end{array}$ & $\begin{array}{c}\text { Salinity } \\
(\%)\end{array}$ & $\underset{(\mathrm{mmoles} / 1)}{\mathrm{Ca}^{++}}$ & $\underset{(\mathrm{mmoles} / 1)}{\mathrm{Mg}^{++}}$ & $\begin{array}{c}\text { Chlorinity } \\
(\%)\end{array}$ & $\begin{array}{c}\text { Lithologic } \\
\text { Unit }\end{array}$ \\
\hline $\begin{array}{l}\text { Surface (1) } \\
\text { Seawater }\end{array}$ & & 7.78 & 2.30 & 35.2 & 10.55 & 53.9 & 19.3 & \\
\hline $\begin{array}{l}\text { Reference (2) } \\
1-3\end{array}$ & & 7.994 & 2.39 & 37.4 & 10.98 & 57.76 & 20.1 & \\
\hline $\begin{array}{l}1-3, \\
2-3\end{array}$ & 119.94 & 6.816 & 2.37 & 55.0 & 35.55 & 77.32 & 29.9 & \\
\hline $3-2 e^{144-150}$ & 138.94 & 6.849 & 1.61 & 58.3 & 47.86 & 73.69 & 31.6 & I \\
\hline $9-3,^{144-150}$ & 148.44 & 6.920 & 1.36 & 59.4 & 52.75 & 74.59 & 31.9 & \\
\hline $\begin{array}{l}140-150 \\
14-4,\end{array}$ & 203.40 & 6.829 & 1.131 & 74.8 & 84.40 & 83.46 & 42.4 & II \\
\hline $\begin{array}{l}140-150 \\
19-4,\end{array}$ & 251.40 & 7.07 & 0.752 & 73.4 & 71.90 & 69.34 & 42.5 & \\
\hline $\begin{array}{l}140-150 \\
24-5,\end{array}$ & 298.90 & 7.464 & 0.576 & 78.1 & 79.52 & 57.08 & 44.0 & III \\
\hline $\begin{array}{l}140-150 \\
29-4\end{array}$ & 347.90 & 6.949 & 0.762 & 83.05 & 79.71 & 59.21 & 48.4 & \\
\hline $\begin{array}{l}140-150 \\
33-5,\end{array}$ & 395.40 & 7.152 & 0.743 & 90.2 & 100.23 & 61.84 & 58.5 & \\
\hline $\begin{array}{l}140-150 \\
35-2,\end{array}$ & 471.40 & 6.979 & 0.860 & 95.7 & 104.13 & 65.47 & 57.1 & \\
\hline $\begin{array}{l}140-150 \\
36-5,\end{array}$ & 536.90 & - & - & 104.5 & 116.44 & 69.94 & 62.7 & \\
\hline $\begin{array}{l}140-150 \\
38-3,\end{array}$ & 579.0 & 7.060 & 0.879 & 106.7 & 118.00 & 65.49 & 63.7 & \\
\hline $\begin{array}{l}140-150 \\
42-5\end{array}$ & 648.9 & - & - & 114.4 & 131.09 & 72.08 & 69.3 & IV \\
\hline $\begin{array}{l}140-150 \\
43-5,\end{array}$ & 794.4 & - & - & 117.7 & 128.9 & 63.81 & 71.1 & \\
\hline${ }_{44-5}^{140-150}$ & 806.9 & - & - & 123.2 & 135.78 & 77.23 & 74.5 & \\
\hline $\begin{array}{l}40-50 \\
45-3\end{array}$ & 840.9 & - & - & 112.2 & 120.35 & 85.14 & 68.1 & \\
\hline $140-150$ & 876.9 & - & - & 110.0 & 118.79 & 72.23 & 66.5 & \\
\hline
\end{tabular}

800 meters (Core 43). A small inflection in both curves is noted at about 200 meters subbottom corresponding to the base of the evaporite formation (Unit II). Below 800 meters the salinity and the chlorinity decreases.

Alkalinity and $p \mathrm{H}$ values are also plotted in Figure 9. The $p \mathrm{H}$ curve shows that the waters remain in the range neutral to mildly alkaline.

Both calcium and magnesium values (Figure 10) show an overall increase with depth. In general the $\mathrm{Ca}^{++} / \mathrm{Mg}^{++}$ratio stays below 1 . However, the ratio slightly exceeds unity in an interval just below the evaporite layers ( 200 to $250 \mathrm{~m}$ subbottom). The maxima were noted at 200 and 800 meters subbottom, corresponding to the two salinity maxima.

The salt concentrations of the interstitial water have an almost linear gradient from the basal rocks to the top of the evaporite formation. This salinity gradient is a pattern observed at all previous DSDP sites where evaporites are present at depth. However, the existence of a downward increasing salinity gradient below the evaporites to a depth of 800 meters subbottom is puzzling. Is the gradient an indication of the existence of an older brine-containing evaporite formation in the
Balearic basin or is the gradient brought about by some other cause?

\section{Carbonate Content}

The carbonate content of Site 372 sediments as measured by the "carbonate bomb" method and later by the LECO apparatus at DSDP, is plotted alongside the hole summary. The graph includes both dominant and minor lithologies causing considerable variation. The section, nevertheless, can be divided on the basis of its $\mathrm{CaCO}_{3}$ content into two distinct units:

1) An upper part (Units II to III) with an average carbonate content of about $50 \%$ (range $30 \%$ to more than $60 \%$ ) within which sediments associated with the gypsum beds (Unit II) have distinctly lower carbonate contents.

2) A lower part, corresponding to Unit IV (Cores 34 to the base of the hole) showing carbonate values between $17 \%$ and $33 \%$ (average about $24 \%$ ). The top of this lowest unit corresponds to a seismic reflector at about 460 meters subbottom depth; and its low carbonate content is related to increased detrital content. 
$\mathrm{pH}$

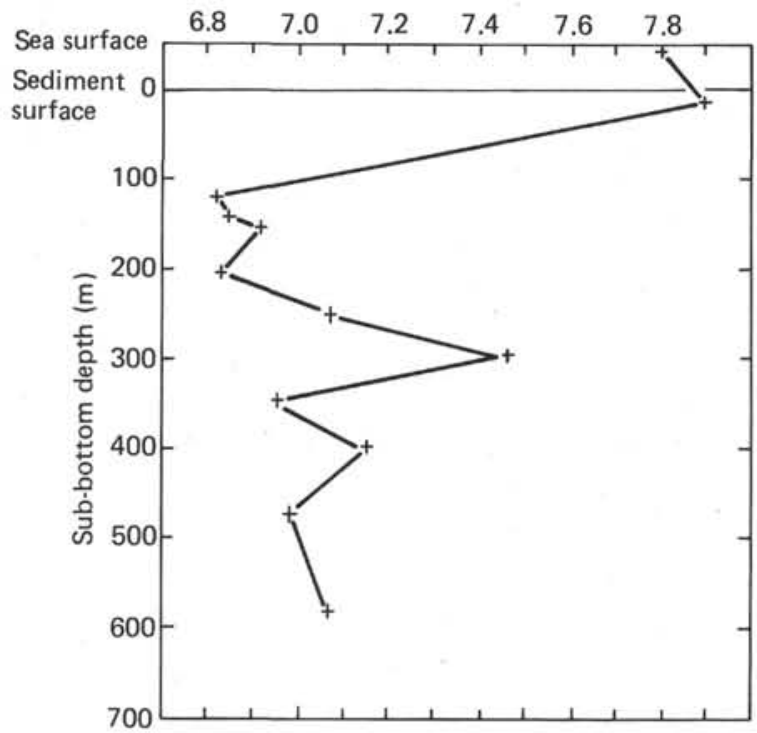

Salinity $(\%)$

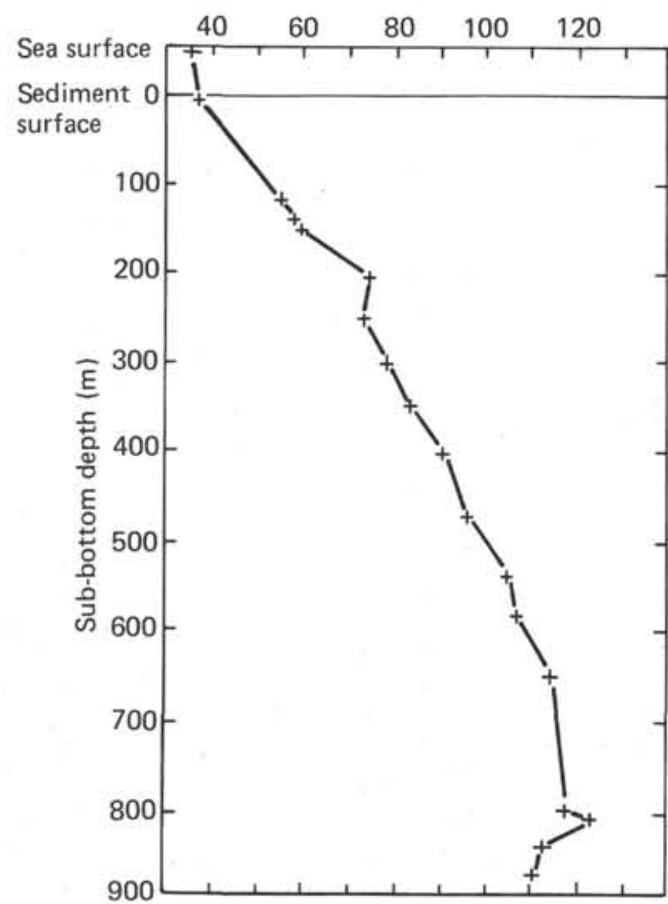

Alkalinity $(\mathrm{meg} / \mathrm{kg})$
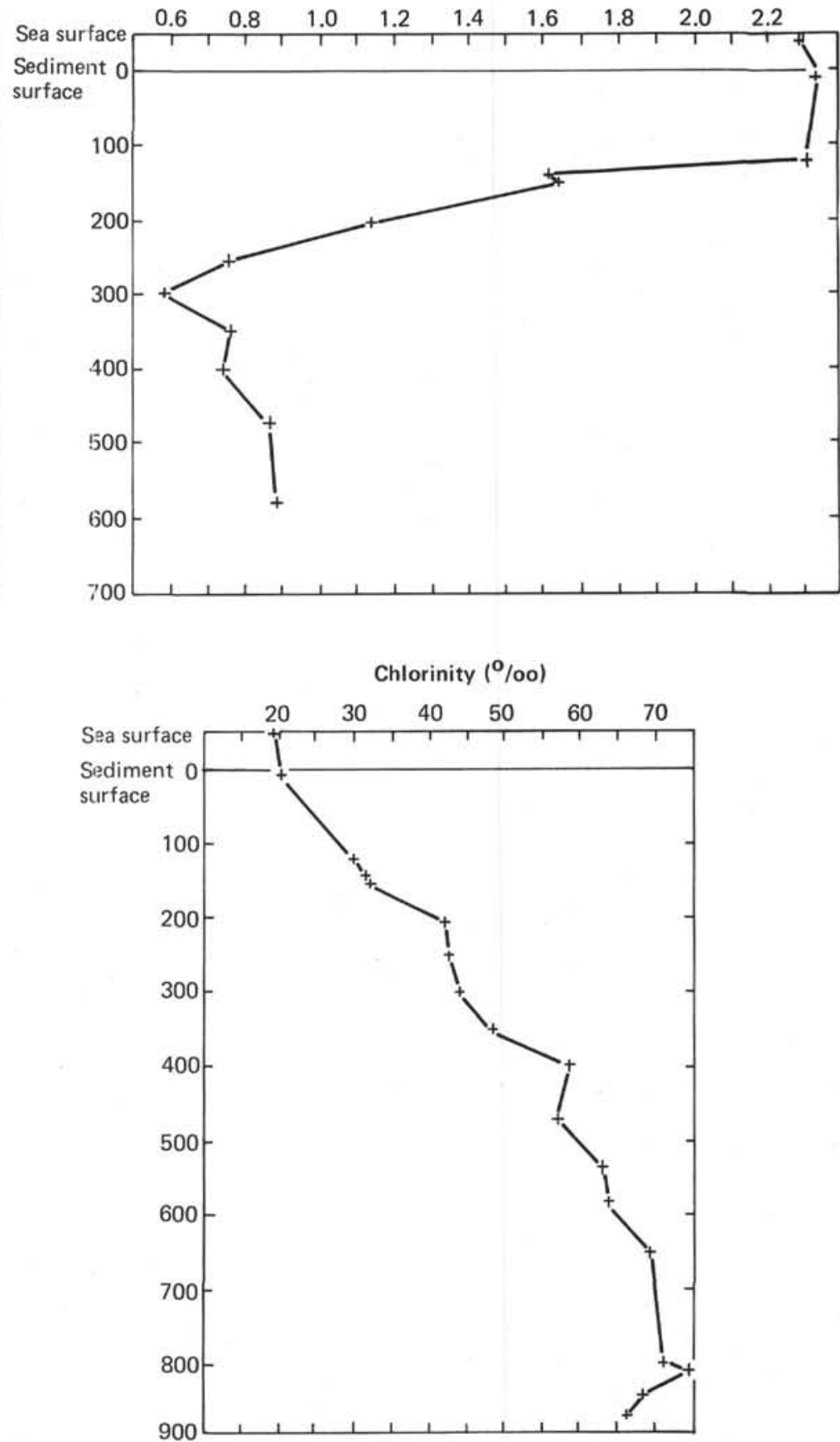

Figure 9. Salinity, chlorinity, $\mathrm{pH}$ and alkalinity measurements at Site 372.

\section{PHYSICAL PROPERTIES}

\section{Sonic Velocity Data}

Seismic velocity increases from about $1.6 \mathrm{~km} / \mathrm{sec}$ (Table 1 of Appendix VI) at 113 meters to $2.5 \mathrm{~km} / \mathrm{sec}$ at a depth of about 715 meters, below which the velocities appear to decrease slightly (Figure 11). The validity of the low velocities obtained below 715 meters was confirmed by remeasuring the velocities on the same chunks which had been used previously, and by using only the results of measurements made by a technician experienced with the measurement equip- ment and procedures. Although no distinct lithologic transition was noted below 715 meters, a change in the trend of most geochemical data occurs at 800 meters, suggesting the possibility that a new lithologic unit was being approached.

Interpretation of seismic profile data constitutes the most valuable method of finding the best place to drill and of correlating the results of drilling to the regional geophysical situation. Since most conventional seismic profile data are obtained in the form of travel times of seismic waves traveling nearly vertical paths through the sediment, it is necessary to know the seismic 


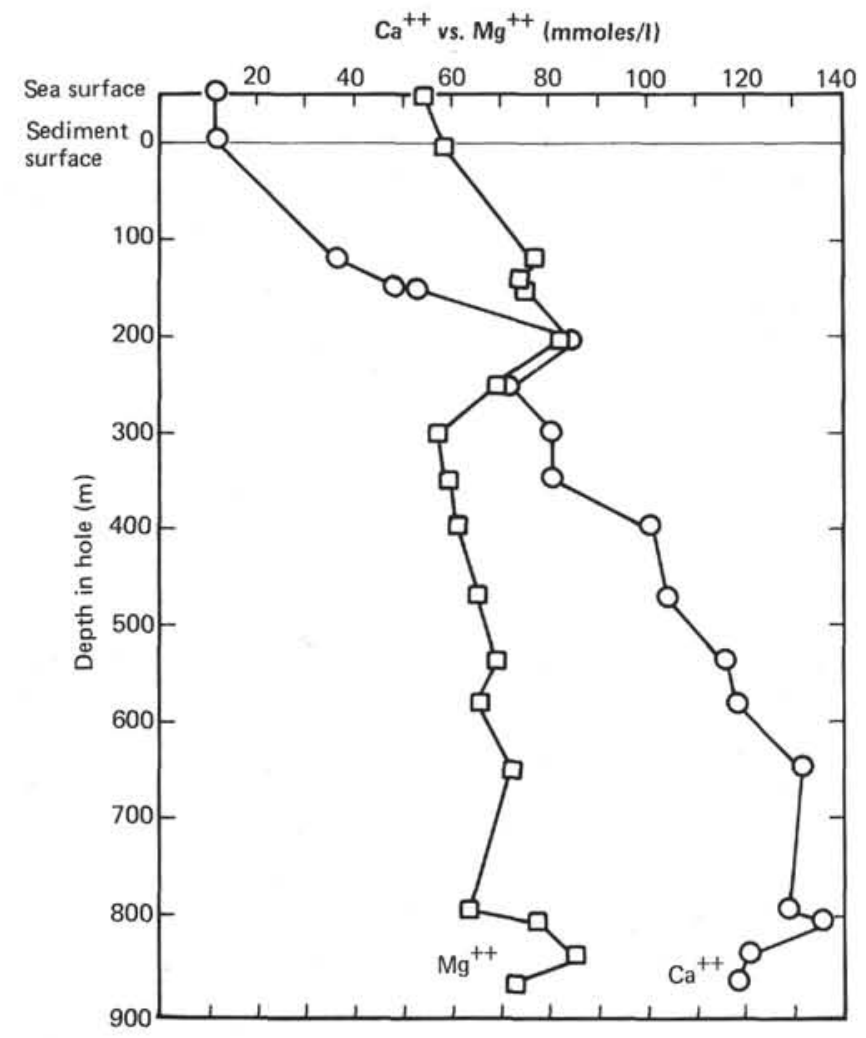

Figure 10. Calcium ${ }^{++}$and magnesium ${ }^{++}$measurements at Site 372.

velocity of the sediments in the vertical direction to convert the travel time data into layer thicknesses and reflector depths. Shipboard seismic velocity measurements on D/V Glomar Challenger are usually made in the horizontal direction on sediments in a split core liner. Measurements of sonic velocity were made in both the vertical and horizontal directions on chunks of consolidated sediment to test the assumption that the vertical and horizontal sonic velocities were equal. It quickly became apparent that the horizontal velocity was, without exception, $3.6 \%$ to $17.6 \%$ higher than the vertical velocity (Table 2 of Appendix VI).

A correction factor " $F$ " was defined as the ratio of the vertical to the horizontal velocity. Thus, the product of a velocity determined in the horizontal direction with " $F$ " should provide an estimate of the vertical velocity. Although " $F$ " is only weakly related to depth, with evidence of anisotropy increasing slightly downward (Figure 12), it appears to be linearly related to the horizontal velocity (Figure 13).

\section{Wet Bulk Density, Porosity, and Water Content}

Gamma ray attenuation was measured through the core liner on selected sections of each core through Core 26. For subsequent cores, attentuation was measured directly through the consolidated core itself after it was removed from the plastic core liner. Gravimetric determinations were also made on both syringe and cylinder samples, as described in Chapter 1. Because of the impossibility of sampling the consolidated

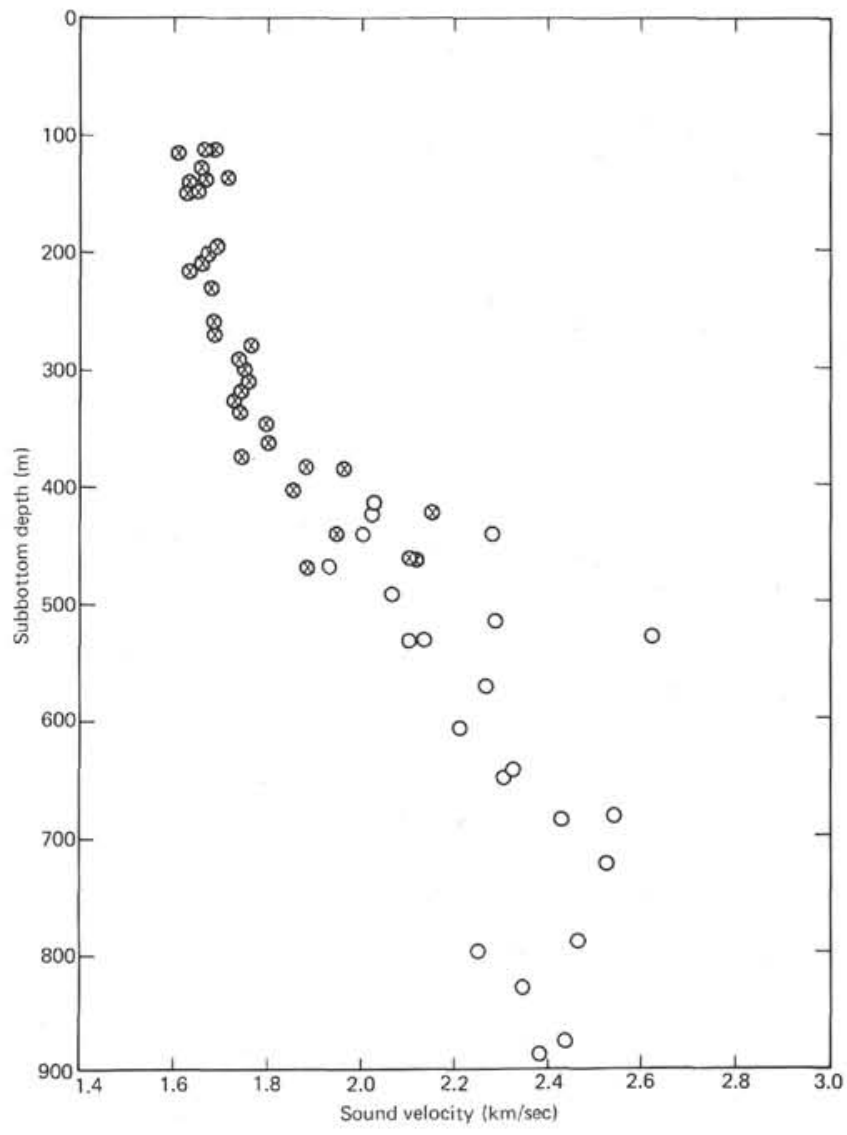

Figure 11. Sound velocity measurements in the horizontal direction made on unconsolidated sediments ( $\odot)$ and on consolidated sediments $(\otimes)$ recovered at Site 372 plotted versus subbottom depth.

mudstones and marlstones in a way that would make volumetric determinations possible, only water content values are available from the gravimetric data below 295 meters subbottom.

Wet bulk density values computed using both gamma ray attenuation (Table 2 of Appendix VI) and gravimetric techniques (Tables 3 and 4 of Appendix VI) are plotted in Figure 14. The data plotted were selected in the following manner: (a) Gravimetric technique-syringe sampling: Bulk wet density values less than $1.6 \mathrm{~g} / \mathrm{cc}$ were rejected as unrealiable. In most cases, densities lower than $1.6 \mathrm{~g} / \mathrm{cc}$ were associated with unrealistically high or low porosities and/or grain densities. Where more than one density value was available from a given core, only the highest value was plotted. (b) Gravimetric technique-cylinder sampling: All density values were plotted. (c) Gamma ray attenuation technique: The highest bulk wet density value in any $15-\mathrm{cm}$ interval of a core was plotted for cores which were subjected to the gamma ray attenuation measurement in the core liner. Where the density was measured on core samples out of the liner, the average density of the entire core was used except for Cores 33 and 34 , where anomalously low values (about 1.7 $\mathrm{g} / \mathrm{cc}$ ) in one section of each core were rejected, leaving a single section average for each core which was 


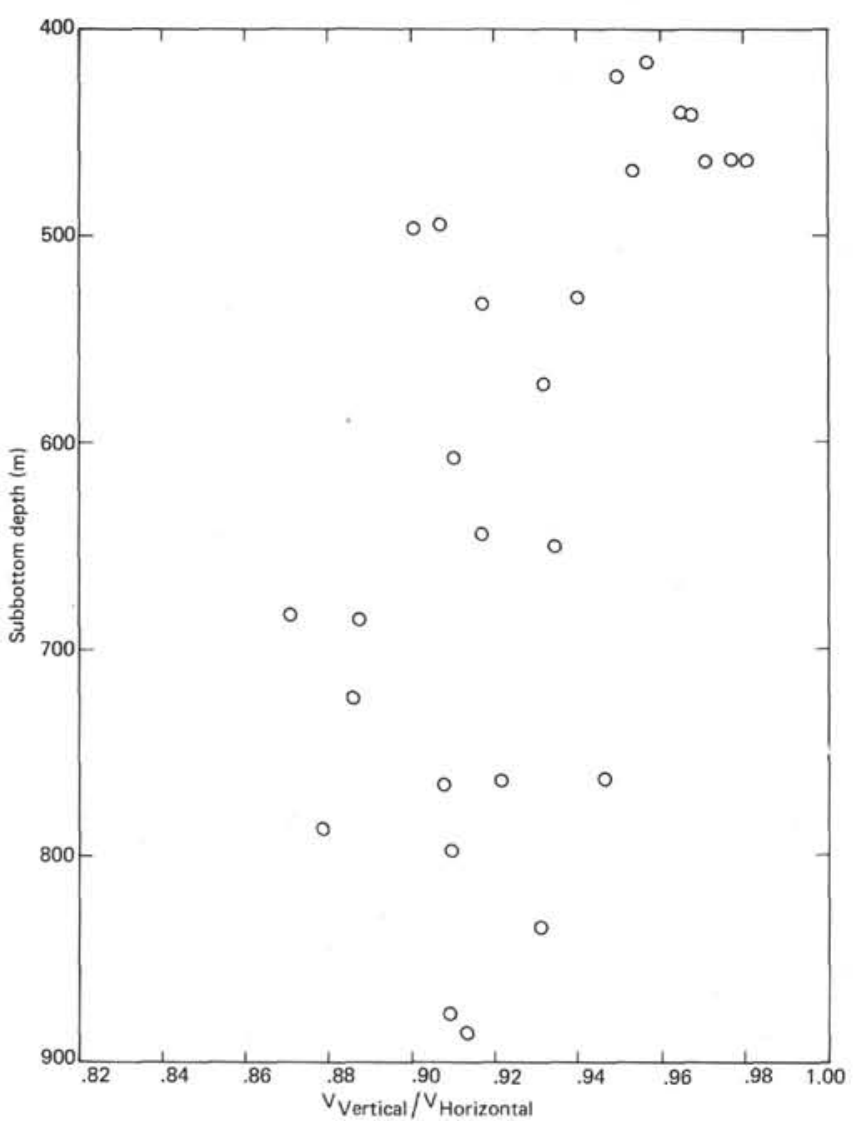

Figure 12. Ratio of vertical to horizontal sound velocity determined on oriented chunks of consolidated sediments at Site 372, plotted versus subbottom depth.

consistent with other density data measured both above and below these intervals.

A clearly defined increase in bulk wet density with depth is visible in Figure 14. Also apparent is the much larger variability in the density data measured in unconsolidated sediments above $\mathbf{4 0 0}$ meters subbottom than measured below 400 meters by applying the gamma ray attenuation technique to consolidated sediments measured outside of the core liner. Both types of gravimetric data are more variable than data computed using the gamma ray attenuation technique. Data obtained using the syringe sampling technique is clearly the most variable, even after rejection of the lowest values.

Two plots of water content versus depth are shown in Figure 15. Water content values calculated gravimetrically using the cylinder sampling technique are less variable than data calculated using syringe sampling. Comparison of Figures 14 and 15 indicates that the water content data in both cases is less variable than the wet bulk density data calculated using the same samples. This suggests that most of the variation in the density data originates from errors in determining the volume of the sample, that is, in the actual sampling procedure itself, rather than in real variations due to compaction or the mechanical disturbances due to handling or drilling.

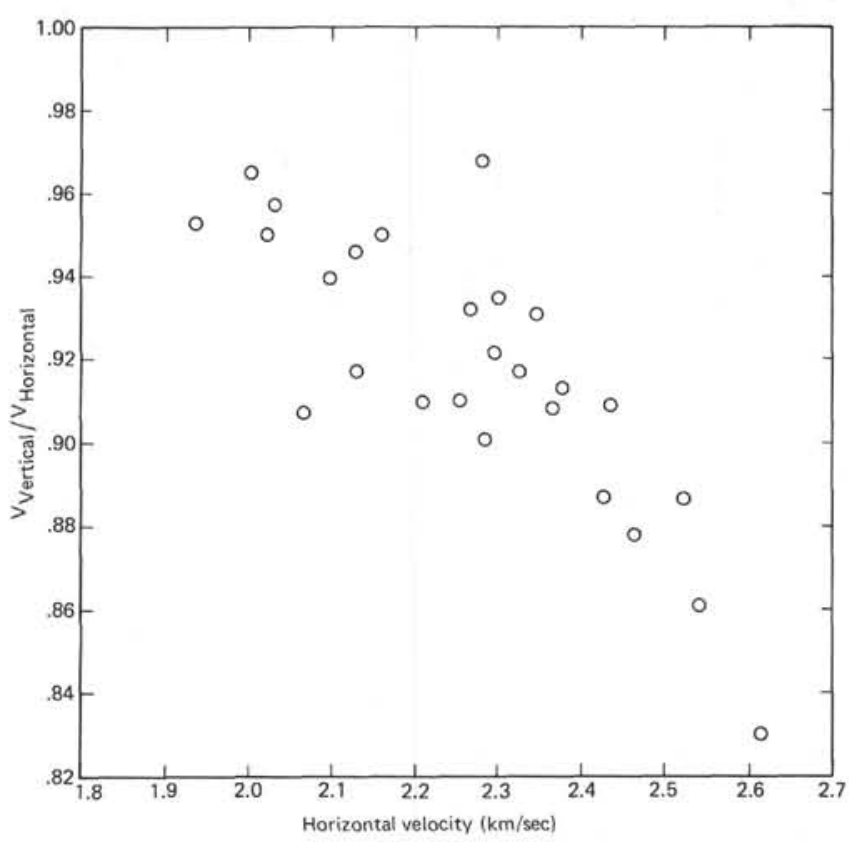

Figure 13. Ratio of vertical to horizontal sound velocity determined on oriented chunks of consolidated sediments at Site 372, plotted versus horizontal sound velocity.

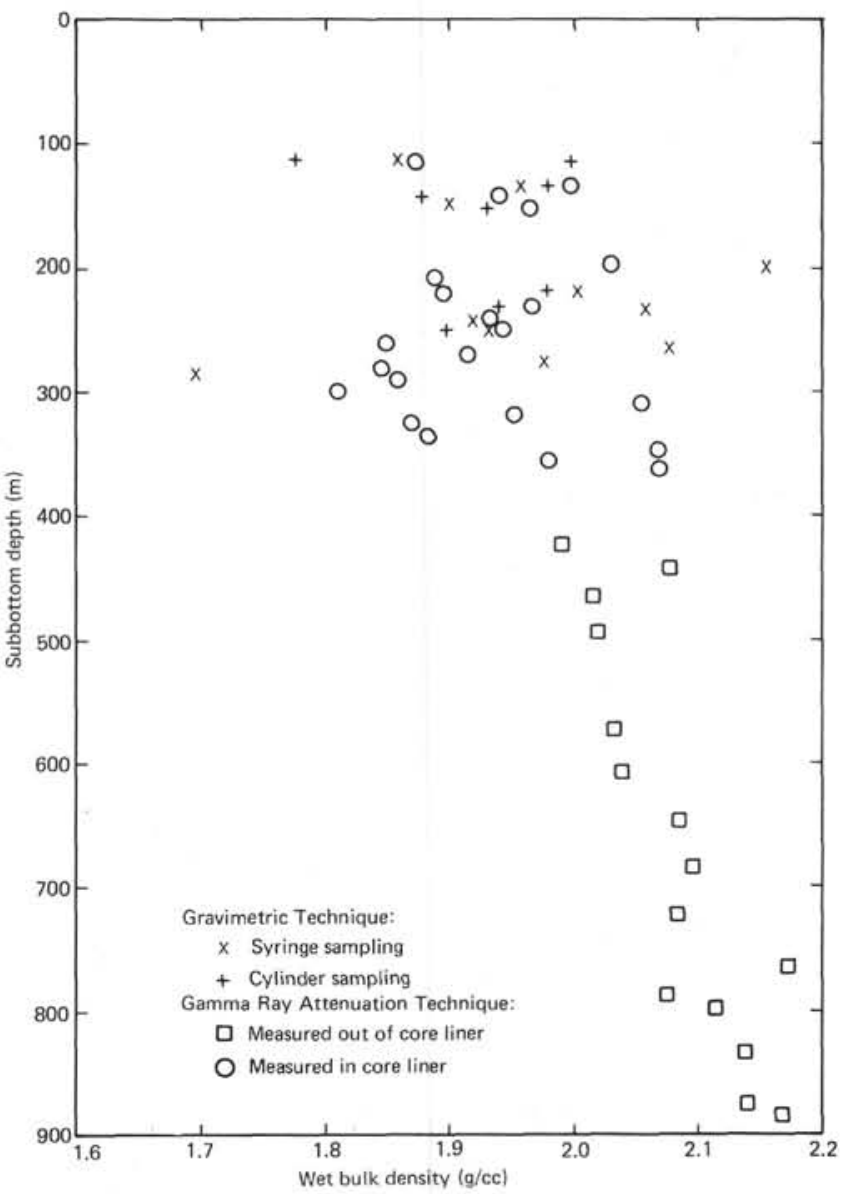

Figure 14. Wet bulk density determined gravimetrically and by gamma ray attenuation at Site 372, plotted versus subbottom depth. 

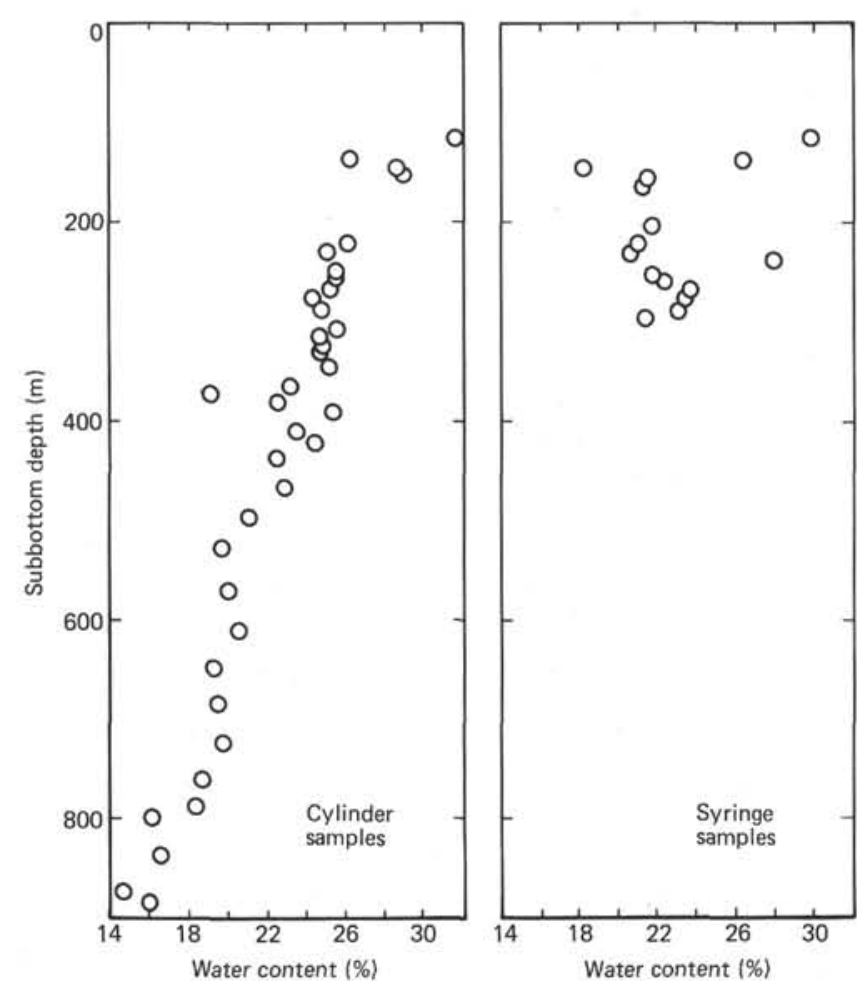

Figure 15. Plots of water content data measured gravimetrically using cylinder sampling and syringe sampling techniques, plotted versus subbottom depth at Site 372 .

Comparison of the water content and bulk wet density data below 400 meters suggests that the forms of the curves determined by these data tend to be mirror images of one another. Although there is nothing unusual in an inverse relationship between density and water content, it is reassuring that physical property measurements made using independent methods are, in fact, correlated in a reasonable way. The overall downward decrease in water content and increase in wet bulk density are consistent with the homogeneous lithology encountered above and below the layer of gypsum and dolomitic marls between 150 and 201 meters subbottom.

\section{Vane Shear Data}

Vane shear data obtained on clay-rich sediments from 116 meters down to 249 meters subbottom are presented in Table 6 of Appendix VI. The data show a rapid downward increase in shear strength from 116 meters to the top of the evaporite layer at 153 meters, and an almost equally rapid decrease in shear strength from the base of the evaporite layer at 201 meters down to 232 meters subbottom, followed by another poorly defined increase suggested by a single data point at 249 meters subbottom. Although the rapid increase in shear strength above 153 meters can be attributed to normal compaction, the decrease in shear strength between 200 and 232 meters is more puzzling. A similar downward decrease has been noted in sonic velocities within this interval, and it is possible that both decreases are a consequence of undercompaction caused by the presence of the overlying impermeable evaporite layer. Alternatively, the decreased shear strength and elastic properties below the evaporite may reflect the effects of subaerial or near-surface weathering prior to and during the early stages of evaporite deposition.

\section{Thermal Conductivity}

Thermal conductivity increases with depth in the nannofossil marls and marlstones recovered at Site 372. All of the values fall in the range between 3.10 and $3.62 \mathrm{mcal} / \mathrm{cm} \mathrm{sec}{ }^{\circ} \mathrm{C}$. The mean and standard deviation of 18 values between 116 and 311 meters subbottom is $3.37 \pm 0.19 \mathrm{mcal} / \mathrm{cm} \mathrm{sec}{ }^{\circ} \mathrm{C}$. Conductivity values measured in cores recovered from the interval between 243 and 311 meters are higher $(3.52 \pm 0.10$ $\mathrm{mcal} / \mathrm{cm} \mathrm{sec}{ }^{\circ} \mathrm{C}, \mathrm{n}=9$ ) than those measured in the interval above 243 meters $\left(3.22 \pm 0.11 \mathrm{mcal} / \mathrm{cm} \mathrm{sec}^{\circ} \mathrm{C}\right.$, $\mathrm{n}=9$ ). This downward increase is probably due to normal compaction. The thermal conductivity data are listed in Table 7 of Appendix VI.

\section{BIOSTRATIGRAPHY}

\section{Summary}

At Site 372 , a sequence of 46 cores, spanning 885 meters of penetration into the Menorca Rise of the Balearic Basin, represents the most complete deep-sea record available of the Mediterranean Neogene (Figure 16). Its continuously cored section covers the 14m.y. period from the Pliocene (Core 2 ) to the middle Miocene (Core 30).

Planktonic foraminifers are abundant, well diversified, and very well preserved in the post-Messinian sediments and also in the pre-evaporitic sediments as far back as the Langhian. In the Burdigalian sediments at the base of the section foraminifers are often sparse and not well preserved, which results in poor biostratigraphic resolution. The marls associated with the evaporitic Messinian yield poor to fairly rich assemblages. Calcareous nannofossile are abundant and well diversified throughout the section penetrated with the exception of the finely laminated sediments recovered in the upper part of Section 2, Core 9, which are distinguished by assemblages having poor diversification. In the interval corresponding to Cores $7,11,13$, and 14 overgrowth on the discoasters is extensive. Benthic foraminifers are rare throughout the section, but are sufficiently diversified and well preserved to be particularly diagnostic of paleoenvironmental changes especially those associated with the Messinian salinity crisis. Special chapters on the histricosphaerids and on the Radiolaria, which were recorded throughout the Miocene succession and were particularly frequent in the lower Miocene, are found in Part II of this volume.

The Quaternary was determined in Core 1 only. The Pliocene sequence, down to Core 4 , shows considerable evidence of being condensed particularly near its base. The Pliocene-Miocene contact recovered at the top of Core 4 is an obvious drilling artifact. The evaporitic formation is inferred to be Messinian in age. Sediments 


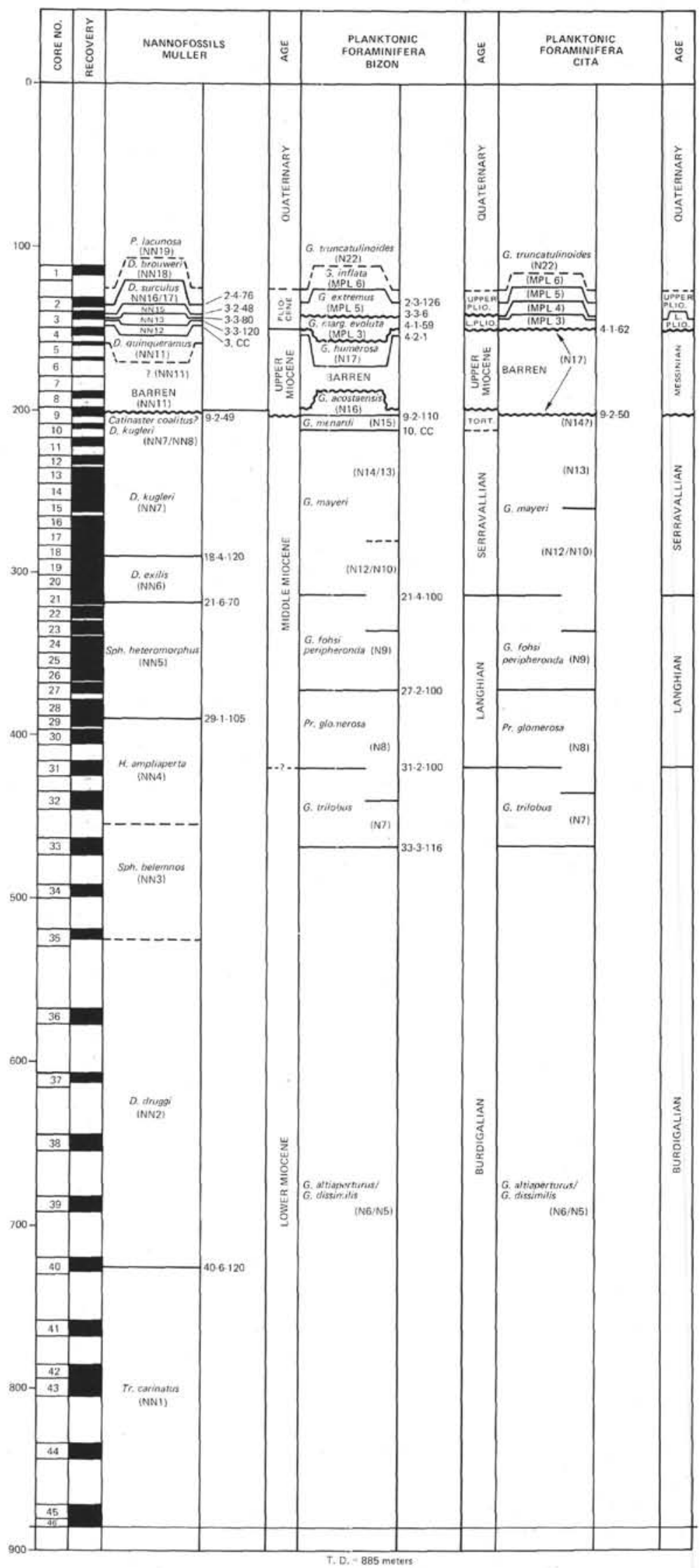

Figure 16. Relative planktonic microfossil zonations, Site 372. 
of the middle and early Miocene make up the remainder of the drilled sequence: about 680 meters. The sediments at the base of the hole are believed to be of lowermost Burdigalian age (about 22.0 m.y. B.P.).

There are certain differences in the biostratigraphic interpretation of Cores 9 and 10. One interpretation (Bizon) considers the varved sequence to be marine, of Tortonian age (NI6), and deposited before the onset of the Messinian salinity crisis. A major hiatus is placed at the top of Core 9, i.e., below the lowest gypsum rocks. A second interpretation (Cita) interprets the varve-like sequence as a deposit of a restricted environment which was prevalent during the Messinian salinity crisis and which is separated from the underlying openmarine sediments of N13/N14 age by a major hiatus at Sample 9-2, $45 \mathrm{~cm}$. The difference between these two interpretations hinges on the placing of the major unconformity whose existence is well known from seismic profiles across this part of the Menorca Rise. Nannofossil evidence (Müller) supports the second interpretation.

\section{Nannofossils}

\section{Quaternary}

In Core 1 (112.0-121.5 $\mathrm{m}$ subbottom) the nannoplankton assemblage of the Pseudoemiliania lacunosa Zone (NN 19) is present with the following species: Pseudoemiliania lacunosa, Cyclococcolithus leptoporus, Syracosphaera pulchra, Discolithina japonica, Helicosphaera carteri, Coccolithus pelagicus. Umbilicosphaera maribalis and Scapholithus fossilis are rare. The sediments are rich in well-preserved nannofossils. Reworked species of the Cretaceous and Tertiary were observed sporadically.

\section{Pliocene}

Core 2 (131.0-140.5 m subbottom) belongs to the upper Pliocene with abundant Cyclococcolithus macintyrei and discoasters restricted to certain horizons. Discoaster brouweri was found in Samples 2-2, 27 $28 \mathrm{~cm}$ and 2-3, 41-42 cm and Discoaster brouweri, Discoaster pentaradiatus, and Discoaster surculus in Sample 2-4, 76-77 cm. Other species are: Helicosphaera carteri, Helicosphaera sellii, Cyclococcolithus leptoporus, Coccolithus pelagicus (abundant), and Pseudoemiliania lacunosa. Discolithina japonica becomes abundant in Sample 2-3, 30-31 cm. The Discoaster surculus Zone (NN 16) was determined from Sample 2-4, 76-77 cm to Sample 3-2, $48-49 \mathrm{~cm}$. Discoaster pentaradiatus and Discoaster surculus are rare, while Discoaster brouweri is common. Coccolithus pelgicus, Helicosphaera carteri, Cyclococcolithus macintyrei, and Pseudoemiliania lacunosa are the most frequent species of this sequence. The sediments are rich in well-preserved nannofossils. No reworked species were found. In Sample 3-3, 80-81 cm the Reticulofenestra pseudoumbilica Zone (NN 15) was determined. Discoasters are only rare while Reticulofenestra pseudoumbilca and Sphenolithus abies are abundant. In sample 3-3, 120-121 cm one specimen of Ceratolithus rugosus was found and Discoaster asymmetricus was absent. This sample may belong to the Ceratolithus rugosus Zone (NN 13).

In Sample 3, CC Ceratolithus tricorniculatus is present sporadically, while Ceratolithus rugosus was not found. It is possible that this sample belongs to the Ceratolithus tricorniculatus Zone (NN 12). These results show that the Pliocene sequence is extremely reduced. Reworked species are missing in this section.

\section{Miocene}

The determination of the Miocene zonal boundaries is somewhat tentative due to the absence of typical discoasters and/or their bad preservation. In most of the samples, discoasters are strongly overgrown making identification of species almost impossible or at least uncertain.

Cores 4 and 5 (150.0-169.0 m subbottom) belong to the Discoaster quinqueramus Zone (NN 11). Some specimens were found similar to Discoaster quinqueramus but without the typical knob in the central area. Other species observed in these cores are: Reticulofenestra pseudoumbilica, Coccolithus pelagicus, Helicosphaera carteri, Cyclococcolithus macintyrei, Sphenolithus abies, Ceratolithus tricorniculatus (rare), Discoaster variabilis, Discoaster surculus, Discoaster cf. calcaris, Discoaster brouweri, Discoaster challengeri, Discoaster icarus, and some species of the genus Scyphosphaera. Sediments are abundant in nannofossils. Coccoliths are slightly overgrown, while the discoasters are sometimes difficult to determine. Reworked species of the Cretaceous and Eocene are rare. Nannofossils are rare in Core 6 only, some reworked species were found. Sample 7, CC is rich in nannofossils, and discoasters are strongly overgrown. This sample also belongs to the Discoaster quinqueramus Zone (NN 11) with Discoaster icarus, Discoaster cf. calcaris, Discoaster surculus, Discoaster brouweri, and Discoaster challengeri. Sample 8, CC is barren of nannofossils. Core 9 (197.5-207.0 m subbottom) is notable for its finely laminated sediments in Sections 1 and 2 ("white" and "gray" layers). The white layers are abundant in nannofossils with an assemblage of low diversity. Sphenolithus abies and a very small Reticulofenestra sp. are almost the only species of these layers. Coccolithus pelagicus, Reticulofenestra pseudoumbilica, and Helicosphaera carteri are present only sporadically. The gray layers are characterized by a high amount of detrital material, increasing the number of reworked species and generally lessening the overall content by nannofossil dilution. These more diversified assemblages indicate the occurrence of short influxes of normal marine water between the restricted white layer sedimentation. Discoasters are missing in the white layers and are only rare in the gray layers.

Comparable nannoplankton assemblages are described by Rouchy (1976) from the fine laminated sediments ("balatino") of the central basin of Caltanisetta (Eraclea Minoa, Montedoro). In Samples 9-1, 115-116 cm, 9-2, $23.5 \mathrm{~cm}$, and 9-2, 49-50 cm very few specimens of Ceratolithus cf. tricorniculatus were found which would place them in the Discoaster 
quinqueramus Zone (NN 11). In the lower part of Core 9, Section 2, the nannoplankton assemblages are more diversified. Discoasters are rare and often overgrown. In Sample 9-2, 100-101 cm very few specimens of Discoaster kugleri (which are more frequent in Section 3) were observed. The shape of Discoaster kugleri in the Mediterranean is different from those known from the tropical areas. The arms are longer and they are more similar to forms described by Bramlette and Wilcoxon (1967) as Discoaster kugleri var. This species has a range from the base of the Discoaster kugleri Zone (NN 7) to the middle part of the Catinaster coalitus Zone (NN 8). The boundary between these two zones cannot be determined in the Mediterranean because Catinaster coalitus is missing. This means that the sequence from Sample 9-2,100$101 \mathrm{~cm}$ to Sample $18-4,10-11 \mathrm{~cm}$ belongs in the zonal interval NN 7 to the middle part of NN 8, i.e., the Serravallian. The sediments are of this interval rich in well-preserved coccoliths, while the discoasters in general are strongly overgrown. Reworked species of the Cretaceous and Eocene are rare in almost all samples. The assemblage consists of Discoaster kugleri, Discoaster exilis, Discoaster subsurculus, Discoaster variabilis, Lithostromation perdurum, Reticulofenestra pseudoumbilica, Coccolithus pelagicus, Helicosphaera cateri, Helicosphaera walbersdorfensis, Sphenolithus abies, and Discolithina multipora.

The above findings indicate the presence of a hiatus of at least 5 to 6 m.y. between Sample 9-2, 49-50 cm and Sample 9-2, 100-101 cm.

The interval from Sample 18-4, 120-121 cm to Sample 21-6, 70-71 cm belongs to the Discoaster exilis Zone (NN 6) with Discoaster exilis, Discoaster subsurculus, and Coronocyclus cf. nitescens (oval). Nannofossils are abundant and well-preserved to overgrown. Reworked species are present sporadically.

From Sample 21, CC to Sample 29-1, 105-106 cm the Sphenolithus heteromorphus Zone (NN 5) was determined with Sphenolithus heteromorphus and Discoaster exilis but without Helicosphaera amplia. perta. In some samples Coccolithus abisectus becomes frequent. The last occurrence of this species is in the Discoaster exilis Zone (NN 6). Sediments are abundant in slightly overgrown nannoplankton.

From Sample 29-5, 70-71 cm to Sample 32-3, 82-83 $\mathrm{cm}$ the Helicosphaera ampliaperta Zone (NN 4) is present with Helicosphaera ampliaperta, Sphenolithus heteromorphus, and Discoaster deflandrei. Nannofossils are abundant, and slightly overgrown.

Down from Sample 32-5, $72-73 \mathrm{~cm}$ to Sample 35, CC Helicosphaera ampliaperta is still frequent. This sequence may belong to the Sphenolithus belemnos Zone (NN 3). Very few specimens were observed similar to Sphenolithus belemnos.

From Sample 36-1, 142-143 cm to Sample 40-4, 23$24 \mathrm{~cm}$ Helicosphaera ampliaperta is only rare. This part of the profile may belong to the Discoaster druggi Zone (NN 2) of the lower Miocene. From Sample 40, CC to Sample 46, CC Helicosphaera ampliaperta is missing and Discoaster deflandrei becomes frequent.
This part of the profile probably belongs to the upper part of the Triquetrorhabdulus carinatus Zone (NN 1) although this species was not itself found. Nannofossils are less abundant in the lower part of the profile, but they are well preserved. The amount of detrital material is increasing, reworked species from the Cretaceous and Eocene were observed in all samples.

\section{Planktonic Foraminifers (Cita)}

With 46 cores recovered over a total penetration of 885 meters, Site 372 provides the best and most complete deep-sea record of the Mediterranean Neogene, especially for the middle and early Miocene.

Foraminiferal assemblages are abundant, well diversified, and very well preserved in the post-Messinian sediments and also in the pre-evaporitic sediments down the Core 29 (Langhian). From Core 30 to the base of the hole, assemblages are often sparse and are not well preserved. The marly sediments intercalated in and immediately overlaying the evaporitic Messinian also yield poor to fairly abundant foraminiferal assemblages, but provide a striking insight on the paleoenvironments which alternated with the essentially abiotic surroundings of the gypsum layers.

\section{Pleistocene}

Core 1,recovered from 112 to 121 meters subbottom, yielded early Pleistocene faunal assemblages. The index species Globoratalia truncatulinoides was recorded in the core-catcher sample. The sediments are hemipelagic with a minor to significant terrigenous input as evidenced by mica flakes and quartz grains in the sand fraction.

\section{Pliocene/Pleistocene Boundary}

The Pliocene/Pleistocene boundary is located in the uncored inverval between Core 1 and Core 2 at approximately 125 meters subbottom.

Pliocene

Highly fossiliferous hemipelagic, condensed sediments of late and early Pliocene age were recovered in Cores 2 and 3, 131 to 150 meters subbottom. Four of the six foraminiferal zones recognized in the Mediterranean deep-sea record (Cita, 1972, 1975) are present. Missing are the early Pliocene zones MPl-2 and MPl-1. Only brief comments on each zone are included here. A range chart listing in detail the recorded occurrence of the individual taxa is provided in Bizon et al., this volume. From top to bottom, the zones are as follows:

\section{Globorotalia inflata Interval-Zone MPl-6}

This biozone is recorded in Section 1 and 2 of Core 2 , where the zonal marker is recorded along with Globoratalia cf. tosaensis, Hastigerina siphonifera, Globigerinoides conglobatus, and Globorotalia crassaformis. Worthy of note is the occurrence of Sphaeroidinella ionica ionica in Sample 2-1, 140-142 cm and of Globorotalia menardii in the same sample. These species suggest warm-temperate conditions, supporting previous observational data on the existence of climatic 
fluctuations with warm episodes in the late Pliocene (Ciaranfi and Cita, 1972).

\section{Globigerinoides elongatus Interval-Zone MP1-5}

This biozone is recorded for Sample 2-4, 60-62 cm to Sample 3-1, 105-107 cm. The zonal marker is consistently recorded along with $G$. obliquus extremus and several species of Globorotalia including G. crassaformis viola and $G$. emiliana.

\section{Sphaeroidinellopsis subdehiscens Interval-Zone MPI-4}

This biozone is recorded in just one sample, Sample $3-2,130-132 \mathrm{~cm}$. The zonal marker is present along with $S$. seminulina, Globorotalia emiliana, G. puncticulata, G. menardii, etc.

\section{Globorotalia margaritae/G. puncticulata Concurrent-range-Zone MPl-3}

This biozone, with both zonal markers will represented along with Globorotalia margaritae evoluta, is present in Sample 3-3, 30-32 cm to the bottom of the core.

Throughout the Pliocene section the sand fractions are rich in glauconite.

\section{Miocene/Pliocene Boundary}

This boundary, as recorded in the topmost part of Core 4 (at $62 \mathrm{~cm}$ ), is an artifact induced by coring operations. The topmost part of the core consists of light gray-brown marls yielding an admixture of planktonic foraminifers belonging to the early Pliocene MPL-3 Zone (Globorotalia margaritae margaritae, $G$. margaritae evoluta, G. puncticulate, etc.), shallow water benthic fauna (Ammonia beccarii tepida), and late Miocene planktonic foraminifers (Globorotalia cf. plesiotumida.). The sand-size fraction also contains gypsum, pyrite, quartz fragments, mica flakes, and glauconite.

\section{Messinian}

Cores 4 to 9 (pars, Sections 1 and 2, $0-50 \mathrm{~cm}$ ) contain the sedimentary expression of the Mediterranean "salinity crisis." Some 27 samples were examined from Cores 4, 5-1, 6-1, 9-1, 9-2. Core 7 (only the core catcher was recovered, with nodular gypsum) displayed lithologies unsuitable for paleontological examinations.

Core 4 consistently yielded dwarfed faunas of both planktonic and benthic foraminifers. The taxa recorded include Globigerina quinqueloba, G. multiloba, G. cf. bulloides, Globigerinita glutinata, and Globorotalia scitula. It is an oligotypical assemblage, and all the taxa are well below their average size. Dwarfness is the result of living under stress conditions, and can be induced by an excess salinity and possibly other contributing factors. Despite the environmental stress, the foraminifers were able to survive, and even to breed, but growth rates were curtailed. No burrowing was noted in the sections of this core, while pyrite is a common constituent of the sand-size fraction of the sediment suggesting some degree of reducing conditions at the sediment/water interface. Of the nine samples examined from this core, only that taken at $130-132 \mathrm{~cm}$ in Section 1 yields a fairly rich and diverse assemblage of planktonic foraminifers, including keeled globorotalias such as $G$. merotumida, $G$. cf. plesiotumida, and G. miozea. This assemblage suggests a dilution of the hypersaline waters or a water mass characteristic of more "normal" open-marine conditions. All the taxa are below their average size. Reworking from older Miocene strata is apparent.

Cores 5 and 6 had very poor core recovery; only one section, some 30 to $40 \mathrm{~cm}$ thick was recovered for each core. Both cores contain finely laminated gypsum overlaying a pink colored gypsum marl. The gypsum marls yield very poor assemblages of dwarfed foraminifers similar to those recorded in Core 4. However, the fauna is less numerous and less diversified suggesting conditions of even more severe stress than in Core 4.

Core 9, Sections 1 and 2, have been studied in great detail. To avoid duplication, reference should be made to Cita et al (this volume) for a discussion of the planktonic foraminifers and their related biostratigraphic and chronostratigraphic implications and to Cita et al. (this volume) for a detailed sedimentary description and discussion of the paleoenvironmental indications provided by the benthic foraminifers and by problematical ultramicroscopic fossils recovered from the white submillimetric varves.

\section{Evidence of a Hiatus at the Base of the Varved Interval}

Again, reference should be made to Cita et al. (this volume) for a thorough discussion of the biostratigraphic criteria which contributed to the assessment by this author that a time gap, corresponding to the entire Tortonian and more, is present in Core 9, Section 2, below the finely laminated (varved) interval. The hiatus falls in an interval of gray marls with white spots and concretions, which have been investigated in detail both mineralogically and geochemically. A detailed range chart is included in Cita et al., (this volume).

The foraminiferal faunas yielded by the "normal" olive-gray marls from the lower part of Section 2, Core 9 (below $100 \mathrm{~cm}$ ) indicate open-marine conditions, normal salinity and bathyal depths. They are Serravallian in age, pre- Globigerina nepenthes datum. The assignment to Zone N 13 of Blow's zonal scheme (1969) besides the recorded absence of Globigerina nepenthes whose first occurrence marks the N 13/N 14 zonal boundary is founded on the following criteria:

1) consistent occurrence of Globigerinoides subquadratus, which becomes extinct in the topmost part of Zone N 13,

2) consitent occurrence of Globorotalia praemenardii, which is present with highly evoluted forms in Core 9 (this taxon becomes extinct in Zone N 13 according to Blow, 1969),

3) consistent occurrence of Globigerina druryi, the ancestor of $G$. nepenthes, recorded also with highly evoluted forms,

4) consistent occurrence of Globorotalia "siakensis," which is here separated from G. mayeri (see Cita 
et al., this volume, Taxonomic Notes): the latter taxon becomes extinct in Core 12, Section 5 (see below).

On the other hand, the foraminiferal faunas yielded by the varved interval $9-2,0-50 \mathrm{~cm}$ are mostly reworked. Besides long-ranging species and/or species which do not range beyond the middle Miocene, they also contain taxa which are not recorded from "normal"' gray marls such as Globigerian nepenthes, Globigerinoides obliquus extremus, Globorotalia acostaensis, and $G$. aff. suterae. All these species are discussed and illustrated in Cita et al. (this volume). Their cooccurrence indicates an $\mathrm{N} 17$ zonal age.

\section{Serravallian}

Samples $9-2,100-102 \mathrm{~cm}$ to $22-4,40-42 \mathrm{~cm}$ yield foraminiferal faunas referable to the Serravallian stage. Range charts are provided in Cita et al. (this volume) for Cores 9-13. in Bizon et al. (this volume) for Cores 14-46. A few comments follow.

With reference to Blow's (1969) zonal scheme, Core 9-2 (lower part) to Sample $15-4,40-42 \mathrm{~cm}$ can be referred to Zone N13. The lower boundary of N 13 is defined by the first occurrence of Sphaeroidinellopsis subdehiscens, which had its lowermost occurrence at Site 371 in Core 15, Section 4. The upper boundar f $_{\text {of }}$ N 13 is based on the first occurrence of Globigerina nepenthes, a species that was not recorded in the prevarved interval of Core 9, as discussed above.

Sampels $15-5,40-42 \mathrm{~cm}$ to $21-4,40-42 \mathrm{~cm}$ are referred to Zones $\mathrm{N} 10$ to $\mathrm{N} 12$ of Blow's zonal scheme. No finer distinction is possible, since these biozones are founded on the evolutionary steps of the Globorotalia fohsi lineage. This lineage is not fully developed in the Mediterranean because of climatic exclusion, so that the only well represented species belonging to this bioseries is Globorotalia peripheroronda, whose extinction horizon is a good biostratigraphic marker in the Mediterranean as shown by Bizon and Bizon (1972) and by Giannelli and Salvatorini (1975). The duration of the biozones based on the Globorotalia fohsi lineage is known to be very short (Ryan et al., 1974).

The N9/N10 zonal boundary is tentatively placed between Cores 23 and 22 . The zonal boundary is defined by the first evolutionary occurrence of Globorotalia peripheroacuta: rare specimens referable to this taxon were occasionally recorded in Core 22 , but never below this core. Biostratigraphic events predating the first occurrence of G. peripheroronda, recorded close to the N9/N10 zonal boundary, include the extinction of Praeorbulina glomerosa circularis, the extinction of Globorotalia birnageae, and the first occurrence of Globorotalia praemenardii.

With reference to the zonation of Bizon and Bizon (1972), the interval under discussion is referable in its upper part to the Globorotalia menardii Zone, in its middle and main part to the Glorotalia mayeri Zone, and in its lower part to the Globorotalia peripheroronda/Orbulina suturalis Zone.

The latter zonal boundary is located between Sample $21-5,40-42 \mathrm{~cm}$, where the topmost occurrence of
Globorotalia peripheroronda is recorded, and Sample $21-4,10-12 \mathrm{~cm}$, where the species disappears.

The location of the G. mayeri / C. menardii zonal boundary is in the lower part of Core 12, in between Samples 12-5, 80-82 cm and 12-4, 70-72 cm. Its identification, however, is subject to discussion because of the inherent difficulties related to the taxonomy of the Globorotalia mayeri plexus. Several authors, including Bolli (1966) and Bizon and Bizon (1972) lump together G. mayeri and G. siakensis. This author does not follow this line. It is considered that $G$. siakensis is a complex species which needs thorough revision (see Cita et al., this volume). The disappearance of Globorotalia mayeri predates that of G. "siakensis": indeed, the latter taxon is recorded up to Core 9, Selection 2 (lower part).

Globorotalia praemenardii is consistently recorded in this interval, with variable abundances. Also recorded are G. miozea and the Globorotalia scitula group. Globigerina drury is consistently recorded, with variable abundances. Representatives of the genera Globigerinopsis and Globigerinopsoides, described respectively from the Miocene of Venezuela (Bolli, 1962) and of Algeria (Cita and Mazzola, 1970) were occasionally recorded from Cores 14 to 18 .

\section{Langhian}

The sedimentary expression of the Langhian stage is represented at Site 372 by Core 22-24 to 31, Section 2. The interval is attributed to Zones N9 and 8 (pars) of Blow's zonal scheme.

The N9/N10 zonal boundary and related problems have been discussed above. The N8/N9 zonal boundary coincides with the first evolutionary appearance of Orbulina suturalis. This zonal boundary exactly corresponds to the boundary between the Praeorbulina glomerosa Zone and the Globorotalia peripherorondal orbulina saturalis Zone in the zonal scheme of Bizon and Bizon (1972).

The first occurrence of Orbulina saturalis is recorded in the samples examined in Sample 27-2, 40-42 cm. Consequently, the zonal boundary is located below this level.

The so-called Orbulina bioseries, deriving from Globigerinoides bisphericus $(=$ G. sicanus) and leading to progressively more spherical forms (the final step of adaptation to buoyancy conditions being Orbulina universa) is beautifully developed in Cores 31 to 28 , where representatives of the genus Praeorbulina are very abundant. The evolution from the more primitive forms of Praeorbulina glomerosa to the more advanced ones ( $P$. glomerosa circularis), which is also observed in the stratotype of the Langhian stage ("Pteropod marls"') is very rapid in our cores. The acme of $P$. glomorosa circularis is in Core 28, Section).

The evoluation of Praeorbulina transitoria, evolving into Orbulina bilobata, parallels that of $P$. glomerosa. The genus Praeorbulina strongly decreases in abundance after the Orbulina biohorizon, and becomes extinct near the top of the Langhian. Globorotalia archaeomenardii, G. praescitula, G. miozea, G. peripheroronda, and G. siakensis are recorded within this 
interval. Well represented also is the genus Globoquadrina, with the species $G$. langhiana, $G$. dehiscens, $G$. altispira altispira, G. altispira globosa, G. larmaeui, and G. baroemoenensis.

The genus Globigerinoides, besides such long-ranging species as G. quadrilobatus, G. sacculifer and G. trilobus includes $G$. bisphaericus which becomes extinct within the Langhian and has its acme immediately before the Praeorbulina datum.

\section{Burdigalian}

The interval Core $31-5,80-82 \mathrm{~cm}$ to Core 46 is referred to the Burdigalian stage. The zonal subdivision, with reference to Blow's zonal scheme, is as follows:

Zone N8-The lower part of N8 predating the Praeorbulina datum is present in Core 31 (lower part) and in Core 32, Section 1. The lower boundary of this biozone is defined by the first occurrence of Globigerinoides bisphaericus (= sicanus), whose lowest occurrence was recorded in Core 32, Section 1.

Zone N7-This is defined as the interval from the last occurrence of Catapsydrax dissimilis to the first occurrence of Glorigerinoides bisphaericus. It is present in Cores 32 (pars) and 33 (pars). The topmost occurrence of Catapsydrax dissimilis was recorded in Core 33, Section 3.

Zone N6-N6 is characterized by the concurrent range of Globigerinatella insueta and Catapsydrax dissimilis. The lower boundary is defined by the first occurrence of the former taxon, which is extremely rare in the Mediterranean due to climatic exclusion. Single specimens of Globigerinatella insueta were found in Sample 33-2, 30-41 cm and as a consequence, the N5/ N6 zonal boundary cannot be identified at Site 372 .

Zone N5-Zone N5 is characterized by the concurrent range of Globoquadrina dehiscens praedehiscens and $G$. dehiscens dehiscens. The lower boundary is defined by the topmost occurrence of Globorotalia kugleri, but this species was not recognized at Site 372 .

As a consequence of (a) the absence of Globigerinatella insueta in most of the samples and (b) the absence of Globorotalia kugleri, the lower part of the Miocene section penetrated at Site 372 is referred to Zones N5/N6 undifferentiated. That Zone N4 is absent is inferred, however, based on negative evidence and not entirely certain.

With reference to the zonal scheme of Bizon and Bizon (1972), the Burdigalian sequence is as follows: the Globigerinoides trilobus Zone, defined as the last occurrence of Catapsydrax dissimilis to the first occurrence of Praeorbulina glomerosa spans the interval 31$5,80-82 \mathrm{~cm}$ to $33-3,40-42 \mathrm{~cm}$. The Catapsydrax dissimilis/Globigerinoides altiaperturus Zone from the first occurrence of $G$. altiaperturus to the last occurrence of $C$. dissimilis covers the interval from 33-5, 38$40 \mathrm{~cm}$ to the bottom of the hole (?).

The foraminiferal assemblages from about the last 10 cores are in most cases poor, and poorly preserved. Among the taxa identified without uncertainty are Cassigerinella chipolensis, Globigerinita glutinata, Glo- bigerina angustiumbilicata, and Globorotalia opima nana.

Globigerinoides altiaperturus is recorded with scattered occurrences up to Sample $32-2,30-31 \mathrm{~cm}$ and Globorotaloides suteri was also identified. Globorotalia siakensis, acrostoma, and obesa are consistently recorded, while the lowest record of $G$. praescitula is at Sample 36-6, 60-62 cm.

Noteworthy is the common occurrence of Radiolaria in the early Miocene together with occasional sponge spicules, histricosphaerids, and plant debris. Several specimens of bathyal ostreids were recorded in Sample $30-2,110-112 \mathrm{~cm}$

\section{Planktonic Foraminifers (Bizon)}

\section{Quaternary}

Core 1 contains the only Quaternary sediments recovered at Site 372. The first occurrence of Globorotalia truncatulinoides is at Sample 1-3, $100 \mathrm{~cm}$. The planktonic foraminiferal assemblages are in general strongly dominated by temperate cold water fauna with Globorotalia inflata, Globigerina bulloides, Globorotalia pachyderma, left and right coiling. Reworked species were observed in samples from Sections 1, 2, and 3 of Core 1 (upper Paleocene, upper Miocene, and Pliocene) and the occurrence of Globigerinoides obliquus in the core catcher is probably also due to reworking.

\section{Pliocene}

A strongly condensed sequence was observed in the Pliosene of Site 372. The several disconformities which are discernible on seismic profiles help to explain the heterogeneous assemblages found in many samples.

Core 2, Sections 1, 2, and 3, contained a late Pliocene microfauna including Globorotalis inflata, Globigerinoides cf. fistulosus, and Globigerinoides obliquus. The first occurrence of Globorotalia inflata was recorded in Sample 2-3, $126 \mathrm{~cm}$. Reworked species from the lower Pliocene including Globorotalia margaritae and from the lower part of the upper Pliocene, including Globorotalia puncticulata and Globorotalia emiliana were found in Core 2, Sections 2 and 3. The boundary between the Globorotalia inflata Zone (MPl-6) and the Globigerinoides elongatus Zone (MPl5) can be drawn approximately between Sections 3 and 4. Sample 2-4, $76 \mathrm{~cm}$ belongs to the Globigerinoides elongatus Interval Zone (MPl-5). In it Globorotalia crassformis and Globorotalia semiliana are abundant.

The Sphaeroidinellopsis subdehiscene Zone (MPl-4) seems to be missing or reworked at the base of MPl-5. The first occurrence of Globorotalia emiliana, which occurs generally at the base of the Globigerinoides elongatus Zone (cf. Sites 125 and 132, Leg 13), was recorded in Sample 3-2, $144 \mathrm{~cm}$.

In Sample 3-3, $6 \mathrm{~cm}$, Globorotalia margaritae is frequent and was found in association with Globorotalia puncticulata (Globorotalia margaritae evoluta MPL3 Zone). Samples 3-2, $115 \mathrm{~cm}$ and 3-2, $144 \mathrm{~cm}$ were 
carefully investigated. A mixed assemblage of planktonic foraminifers occurs with Globorotalia emiliana, Globorotalia bononiensis, Globorotalia puncticulata, and some Globorotalia margaritae (probably reworked). Typical Sphaeroidinellopsis were not recorded in these samples. The possibility of a hiatus is in good accordance with the seismic profiling data which indicate that the Plio-Quaternary sequence pinches out towards the Menorca Rise.

The interval between Samples 3-3, $6 \mathrm{~cm}$ and 4-1, 59 $\mathrm{cm}$ belongs to the Globorotalia margaritae evoluta Zone (MPI-3). The lower part of the Pliocene was not recorded. This can be the result of a drill-break encountered at the Miocene-Pliocene boundary where several meters of sandy material were washed away between Cores 3 and 4 . The top of Core 4 is probably a downhole contamination. A hiatus at this level seems to be even more probable in light of disconformities discernible on the seismic reflection profiles.

\section{Miocene}

In Samples 4-1, $61 \mathrm{~cm}$ and 4-1, $140 \mathrm{~cm}$, a dwarfed microfauna was recovered from a greenish-gray mud, including numerous Turborotalita quinqueloba, some small Globorotalia ex gr. manardii, and some Globorotalia scitula. In one sample $(4-2,1 \mathrm{~cm})$ better preserved microfauna was found belonging to the Globorotalia humerosa Zone (N17) and more specifically the Globorotalia mediterranea Subzone of the uppermost Miocene containing Globorotalia acostaensis, Globorotalia humerosa (left coiling), Globorotalia mediterranea, Globorotalia exserta, and Globigerinoides obliquus extremus.

Some Turborotalita aff. quinqueloba were recorded in the gypsiferous dolomitic marls of Cores 5 and 6 . Sample 8, CC was barren.

Sample 9-1, $96 \mathrm{~cm}$, just below the lowest gypsum, contained Ammonia becarrii tepida and small Bolivina associated with a dwarfed planktonic microfauna, an assemblage indicative of a restricted environment, and an age placing it in the Globorotalia acostaensis Zone (N16). The Globorotalia humerosa Zone (upper Miocene) is missing below the evaporite layers, with a hiatus of approximately 1.5 m.y.

As no data are available for the upper part of Core 9 and for the Core 8 evaporites, it is impossible to give an accurate age for deposition of the lower part of the evaporites at this site. We can only say that it cannot be older than the Globorotalia acostaensis Zone (N16). From Samples 9-1, $96 \mathrm{~cm}$ to $9-2,110 \mathrm{~cm}$, the planktonic foraminiferal assemblages are characteristic of the Globorotalia acostaensis Zone. Ammonia beccarii tepida was recorded from Sample 9-1, $96 \mathrm{~cm}$ to Sample $9-2,41 \mathrm{~cm}$. The planktonic foraminiferal assemblages seem to be in place in this interval, with a few species reworked. This association of lagoonal species (A. beccarii tepida) with planktonic species is difficult to explain and will be discussed in the chapter on correlations of Site 372 with nearby land sections (Bizon et al., this volume).

The interval 9-3, $20 \mathrm{~cm}$ to $10, \mathrm{CC}$ represents the Globorotalia menardii Zone of Bolli (.Globorotalia continuosa Zone of Blow, N. 15).
The interval between 11-1, $120 \mathrm{~cm}$ and $21-4,100$ $\mathrm{cm}$ belongs to the Globorotalia mayeri Zone of the Mediterranean area, based on the last occurrence of Globorotalia ex gr. mayeri-siakensis in Sample 11-1, $120 \mathrm{~cm}$ and the last occurrence of Globorotalia fohsi peripheroronda in Sample 21-5, $131 \mathrm{~cm}$. This zone is equivalent to the interval between the Globorotalia mayeri Zone and the Globorotalia fohsi (part) Zone in the Bolli zonation. In the Blow zonation, it is equivalent to the interval between N14 and N10 (part).

The planktonic foraminiferal assemblages are very rich in Globorotalia gr. mayeri-siakensis, Globoquadrina altispira, Globorotalia gr. miozea, Globorotalia gr. menardii, and Globiginoides subquadratus. The first occurrence of Globorotalia gr. menardii occurs between Cores 17 and 18. Alternating assemblages with keeled Globorotalia or turborotaliid Globorotalia are observed. It seems that the repartition of planktonic foraminiferal assemblages at this site is closely linked to fluctuations in the thermal structure of the oceanic water masses. The influence of cold water from the Atlantic ocean is probably very important as the Globorotalia miozea group is fairly well developed here. The absence of the Globigerinoides subquadratus-ruber morphotypes cannot be used here to recognize the interval between uppermost Zone N13 and lowermost Zone N16, as in the tropical areas. This interval requires further investigation especially on the Globorotalia miozea and Globorotalia menardii groups.

The sequence from Samples 21-5, $131 \mathrm{~cm}$ to $27-2$, $100 \mathrm{~cm}$ belongs in the Globorotalia fohsi peripheroronda-Orbulina saturalis Zone of the Mediterranean area. This zone is equivalent to the Globorotalia fohsi peripheroronda Zone and the Globorotalia fohsi Zone (part) of the Bolli zonation. In the Blow zonation, it is equivalent to the Zones N 9 and N 10 (part).

Samples $27-2,130 \mathrm{~cm}$ to $31-2,100 \mathrm{~cm}$ are characteristic of the Praeorbulina glomerosa Zone. The first Praeorbulina glomerosa occurs at $31-2,100 \mathrm{~cm}$. Below this, Samples $31-5,90 \mathrm{~cm}$ to $33-3,116 \mathrm{~cm}$ belong to the Globigerinoides trilobus Zone of the Mediterranean area with the last occurrence of Globigerinita dissimilis in Core 33, Section 4. From this level to Sample 45-6, $127 \mathrm{~cm}$ the foraminifers are diagnostic of the Globigerinita dissimilis-Globigerinoides altiaperturus Zone of the Mediterrbanean area. This zone is equivalent to the Globigerinita dissimilis and Globigerinita stainforthi zones of the Bolli zonation and the N 5-N-6 of the Blow zonation.

Core 49 probably belongs to the same zonal interval. Sandy layers increase towards the base of the hole and the planktonic foraminiferal assemblages are very poor. Globorotalia kugleri was not recorded, and we can only say that this core is not older than N 5 (Globigerinita dissimilis Zone of Bolli), Burdigalian "pars auctorum."

\section{Benthic Foraminifers}

The benthic foraminifers of the Pliocene-Pleistocene section are typical deep-water forms including the upper mesobathyal (>1000-1300 m) species Articulina tubulosa, Astrononion umbilicatalum, Bulimina inflata, Cibicides kullenbergi, and $C$. wuellerstorfi. 
The well-preserved benthic foraminiferal assemblages include other deep-water species which are characteristics of the lower epibathyal $(>500-700 \mathrm{~m})$ Zone, i.e., Cibicides bradyi, Gyroidina lamarckiana, Pullenia bulloides, and Uvigerina peregrina. The planktonic foraminiferal tests in the samples always comprise $95 \%$ of the foraminiferal population, a figure which reinforces the deep-water interpretation of this fauna. There is minor evidence of occasional downslope displacement in the Pleistocene and upper Miocene section as indicated by a few worn outer shelf and upper epibathyal specimens.

The fossiliferous Messinian sediments lying just above the barren Messinian evaporitic sediments (4-1, $70 \mathrm{~cm}$ to $4, \mathrm{CC}$ ) are characterized by a mixed dwarfed benthic foraminiferal fauna, dominated by Bolivina, and indicative of restricted, poorly oxygenated conditions (see Cita et al., this volume).

Cores 5 to 8 are barren of benthic foraminifers. The laminated and fossiliferous sequence just below these barren evaporitic sediments $(9-1,113 \mathrm{~cm}$ to $9-2,41$ $\mathrm{cm}$ ) contains a strange mixture of a restricted inner shelf fauna (Ammonia beccarii) with a deep-water (at least lower epibathyal) assemblage (Epistominella exigua, E. rugosa convexa, E. umbonifera, Eponides umbonatus and Pullenia quinqueloba). These separate assemblages may be mixed together as the result of indiscriminate sampling from and mixing together of the adjacent laminae in the core. If both assemblages are in situ, it seems likely that each has come from a different lamina. The juxtaposition of such widely different assemblages is difficult to explain, but may be the result of periodic flooding of a deep desiccated basin. There is a marked increase in the proportion of Bolivina in Core 9, Section 1 and Core 9, Section 2 compared to the lower parts of the sequence. This change in fauna probably indicates a decrease in oxygenation just prior to the onset of the evaporite deposition.

From Sample 9-2, $60 \mathrm{~cm}$ downwards the benthic foraminiferal assemblages display upper mesobathyal species such as Astrononion umbilicatulum, Bulimina inflata, Cibicides kullenbergi, C. weullerstorfi, and Eponides polius. A number of species whose general upper depth limits are in the lower epibathyal zone are also present: Cibicides bradyi, Osangularia cultur, and Puellenia bulloides. The deep-water interpretation of these samples is supported by the proportional contribution of planktonic tests to the foraminiferal population. Planktonic tests always comprise $87 \%$ and usually $95 \%$ of the fauna.

In the lower Miocene sediments there are fewer species and fewer specimens than in the upper parts of the sequence. Despite that the water was at least as deep as the upper mesobathyal range. Even in the lowest cores (Burdigalian) the water was at least in the lower epibathyal depth range.

\section{SEDIMENTATION RATES}

Marked changes in sedimentation rates are calculated for the Quaternary and Neogene section drilled at Site 372 . Some are directly attributable to its partic- ular location on the Menorca Rise, where the Mediterranean Evaporite formation is known from seismic reflection profiles to pinch out and other angular disconformities are clearly discernible. Other changes in rate are obviously related to changes in lithology within the drilled section.

Figure 17 shows a plot of subbottom depths of zonal boundaries, as recorded by the planktonic foraminiferal and nannofossil paleontologists, set against an absolute time scale as in Ryan et al. (1974).

The base of the Quaternary is put by interpolation between Cores 1 and 2, at around -125 meters. The average sedimentation rate for this period is therefore about 70 meters per million years $\left(6.9 \mathrm{~cm} / 10^{3} \mathrm{yr}\right)$.

While each paelontologist concurs with the seismic profiling evidence that the Pliocene section at Site 372 is strongly condensed, there is some disagreement in the placing of hiatuses. For example, both Cita and Bizon recognize a hiatus, spanning about $1 \mathrm{~m} . y$. , at the base of the Pliocene, with Zones MPl-2 and MPl-1 missing, while Bizon only recognizes the absence of the MPl-4 zone. It is worth noting, however, the truly condensed nature of the Pliocene section here. About 25 meters of nannofossil marl represent the full 3.4m.y. time span of the Pliocene.

There are major differences in the biostratigraphic interpretation of the upper Miocene section which make it difficult to record a sedimentation rate for that interval. While Cita and Müller recognize a hiatus in Core $9(199.5 \mathrm{~m})$ which spans the whole of the Tortonian stage and more ( $\sim 7$ m.y.), Bizon records a hiatus which does not span all of the Tortonian but still includes much of the Messinian.

The Serravallian (middle Miocene) marls and marlstones, which make up most of Lithologic Unit III, were deposited at rates of around $4.2 \mathrm{~cm} / 10^{3} \mathrm{yr}$, while those of the Langhian which complete the middle Miocene section were deposited at the increased rate of $10.5 \mathrm{~cm} / 10^{3} \mathrm{yr}$. Below these no further change in sedimentation rate is recorded for the early Miocene, even though there is a change in lithology from marlstones to mudstones with a more detrital aspect. These Burdigalian mudstones, which make up the major part of Unit 4, were deposited at a rate of about $10.3 \mathrm{~cm} / 10^{3} \mathrm{yr}$ if the terminal depth $(885 \mathrm{~m})$ is taken as lowermost Burdigalian in age. There is some evidence, from the lowest nannofossil zonal boundary determinations, of fluctuating rates within this sequence. The most significant of these gives a rate of deposition for the lowermost Burdigalian of $31.2 \mathrm{~cm} /$ $10^{3} \mathrm{yr}$. This is supported to some extent by the presence of sandstones near the base of the hole which are believed to result from turbiditic deposition related to tectonic instability.

\section{CORRELATION OF SEISMIC REFLECTION PROFILES WITH DRILLING RESULTS}

A correlation is established of the Site 372 section with seismic reflection profiles made during the IFP site survey. The multichannel seismic equipment used for this survey allow detailed calculation of interval 


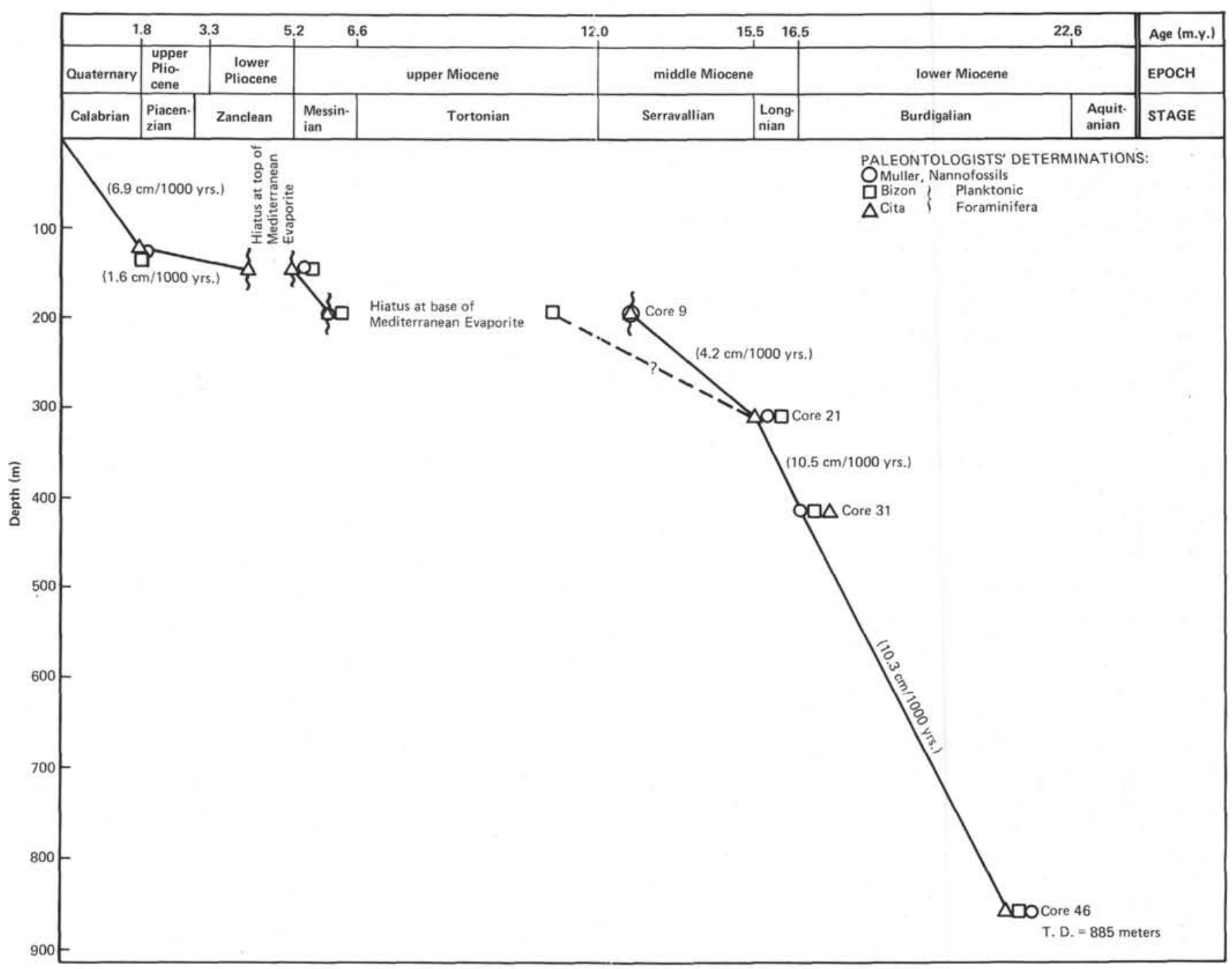

Figure 17. Sedimentation rates at Site 372.

velocities and determination of a mean two-way travel time versus depth curve, which is especially informative for the pre-evaporitic layers (Figure 18).

This curve suggests a progressive increase in compaction and demonstrates that the pre-evaporitic layers outcropping in the area have never been previously overlain by thick late Neogene deposits. The velocity of these layers is about $3.9 \mathrm{~km} / \mathrm{sec}$ in the abyssal plain, under a thick cover of evaporites and Plio-Quaternary sediments. On the same figure, the plot of a similar curve, established during Leg 13 at Site 124 (Ryan, Hsü, et al., 1973) for the Plio-Quaternary, shows an identical trend that corroborates this.

Site 372 was located on IFP profile J204 close to the pinch out of the Plio-Quaternary sediments and evaporites (Figure 5). The following main seismic units can be defined by their seismic character and their depth determined from the velocity curve:

A successful sonobuoy was run and showed again the same major reflectors as on the J204 profile.

The lithostratigraphic results of Site 372 are in close agreement with the seismic data:
1) The base of Plio-Quaternary is at about 150 meters subbottom depth.

2) The base of the evaporite formation is at about 200 meters subbottom depth.

3) The base of seismic Unit 3 corresponds to a sharp contrast in lithology at a depth of about -460 meters marked by a strong decrease in $\mathrm{CaCO}_{3}$ content and a corresponding increase in clays (boundary of lithologic Units III and IV).

4) The base of seismic Unit 4 does not have a marked expression. It appears to correspond to the hard layer indicated by drilling break at 841 meters subbottom.

5) Seismic Unit 5 is marked by numerous strong reflectors. It was drilled for only about 40 to 50 meters. The reflectors probably correspond to the numerous sandy layers observed in the basal sediments of Site 372.

Figure 19 is an interpretation of the IFP seismic profile J204 from the drilling results at Site 372 . 


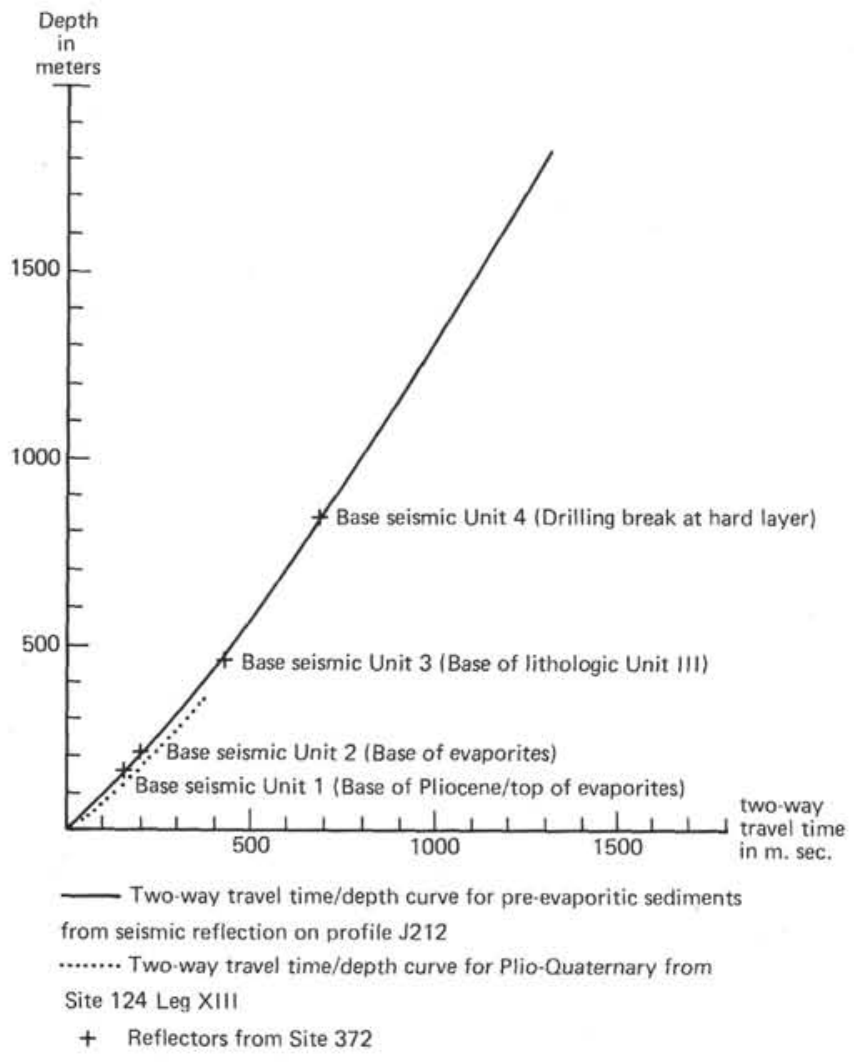

Figure 18. Site 372, two-way travel time versus depth curve.

\section{SUMMARY AND CONCLUSIONS}

Site 372 was located on the deep part of the East Menorca Rise at $40^{\circ} 01.86^{\prime} \mathrm{N}$ and $4^{\circ} 47.79^{\prime} \mathrm{E}$ in 2734 meters of water. The hole penetrated 885 meters into clayey mudstones of probable early Burdigalian age and had to be abandoned when the drill bit collapsed.

The drill site was chosen from an IFP seismic survey run in 1974. The profile shows a pinching out of the Messinian evaporites and the Plio-Quaternary of the deep basin toward the Menorca continental margin which causes outcrop of the pre-evaporitic layers. The main objectives of drilling this site were (a) to obtain information on age and nature of the pre-evaporitic layers for reconstruction of the structural evolution of the Algero-Provencal (Balearic) Basin, and (b) to establish any changes in environment before the Messinian salinity crisis in order to better establish the model of deposition for the evaporites.

The upper half of the hole was cored continuously, while its lower half, drilled through the evaporitic and pre-evaporitic sequence, was cored intermittently.

The section penetrated can be broadly subdivided into four stratigraphic units ranging in age from Quaternary to early Miocene.

Unit I consists of Quaternary and Pliocene nannofossil marls about 150 meters thick. The sediments are light olive-gray to light gray and are relatively soft. There are indications of several hiatuses in Pliocene sedimentation, and the lowest Pliocene sediments are definitely absent. This is in accordance with the seismic profiling data, which indicate that the thick Plio-
Quaternary sequence under the central Balearic abyssal plain pinches out towards the Menorca Rise, and is relatively thin and incomplete at this site. The PlioQuaternary sediments are entirely open marine. Benthic foraminifers indicate water depths in excess of 1500 meters.

The interstitial water shows an increase in salinity with depth caused by the migration of ions from the interstitial brines of evaporites (McDuff and Gieskes, this volume) as observed repeatedly in holes drilled during Leg 13 (Mediterranean) and Leg 23 (Red Sea). Unit II is an evaporite formation consisting mainly of gypsum and dolomitic marls. The age of this unit is N17 for the whole unit (Cita) or that part above the lowest gypsum (Bizon). The unit is approximately 50 meters thick and here represents only a pinch-out wedge of the Mediterranean Upper Evaporite formation on the margin of the Balearic abyssal plain. Also recovery was very poor. The three dominant lithologic types are: (1) white to dusky yellow-green, laminated and nodular gypsum, (2) greenish-gray, soft to stiff pyritiferous dolomitic marls, some of which are nannofossil-bearing with only traces of burrows or none at all. (3) varve-like dolomitic nannofossil marls.

The marls are of three main types: (1) marls barren of fossils (e.g., 8, CC) (2) marls yielding rare planktonic foraminifers but barren of nannofossils (e.g., 6, CC). (3) marls yielding planktonic microfossils and nannofossils and/or benthic foraminifers (e.g., 4-1, 128 $\mathrm{cm})$.

The planktonic and benthic foraminifers are almost invariably small or dwarf forms. All three foraminifer specialists agree (with perhaps somewhat different degrees of conviction and confidence) that the reduction in size was related to abnormal ecological conditions. The environment was stressed, but still permitted reproduction and survival of dwarf forms of some marine organisms. At times the conditions may have become so sterile that marls barren of fossils were deposited. At other times, the basin water was saturated with carbonates and with calcium sulfate, resulting in the formation of dolomite and gypsum. A tentative reconstruction of the lithology suggested three marl-gypsum cycles during the time represented by this incomplete section of the Mediterranean Evaporite. More cycles have been recognized at Site 374 where a more complete section is present (Garrison et al., this volume).

Unit II is separated from Unit III by a change in lithology, by a remarkable change in fauna, and by an unconformity. The latter is clearly shown on seismic profiles (Mauffret et al., this volume). The unconformity is placed at Sample 9-2, $45 \mathrm{~cm}$ or about 199.5 meters subbottom. For a detailed discussion of the placing of this unconformity (see Cita et al., this volume).

Above, the sediment is characterized by the very regular laminations of dolomitic nannofossil marls (varve sequence). The preservation of the varves signifies the absence of current and burrowing activities. Immediately below the hiatus, the sediments are mainly dark gray marl, with some pyrite-rich layers. 


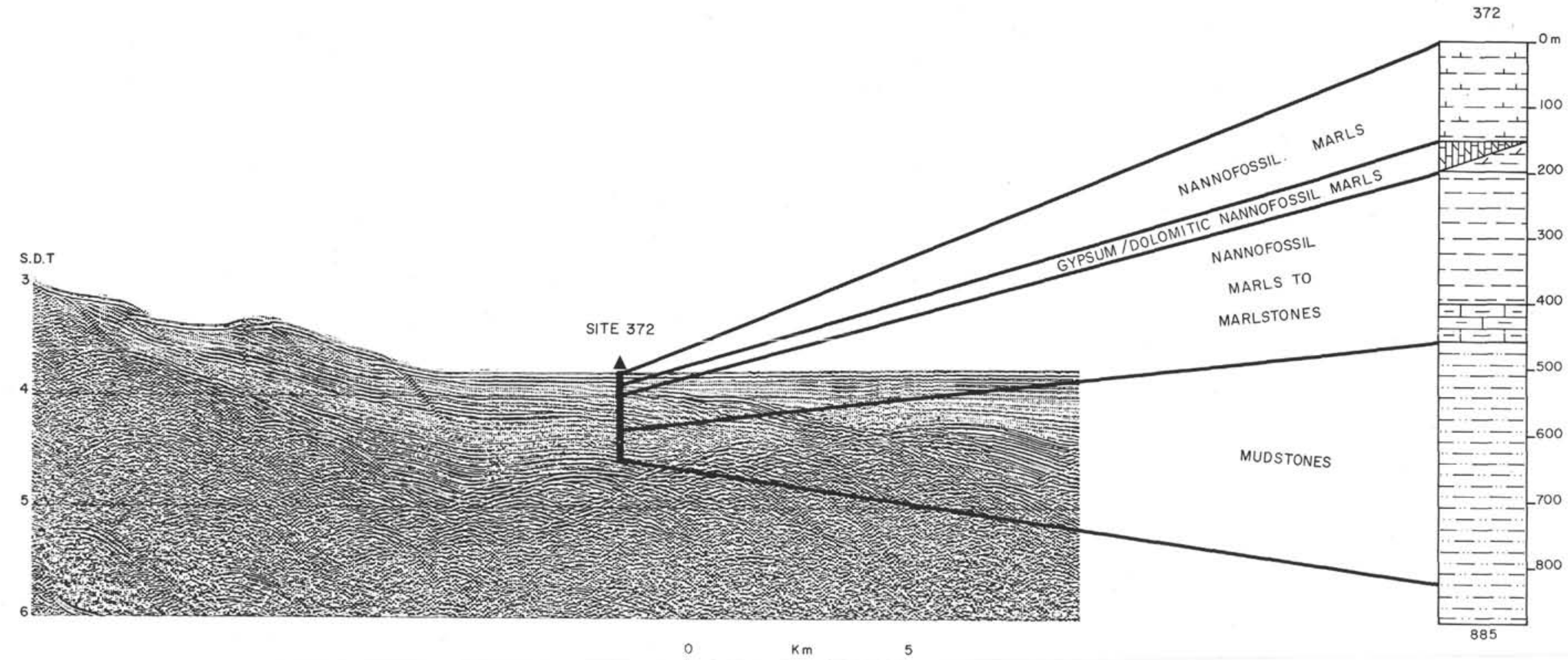

Figure 19. Correlation of the IFP profile 1204 with drilling results at Site 372. 
The existence of an appreciable benthic community was indicated by traces of bioturbation (e.g., Sample $9-2,58-95 \mathrm{~cm}$ ). Transient bottom-current circulation is suggested by fine cross-laminations (e.g., Sample 9-2, $47-50 \mathrm{~cm}$ ). The faunal difference across the contact is equally remarkable. These varves contain a planktonic foraminiferal assemblage of keeled globorotalids, nondiversified nannofossils, and a benthic fauna of Ammonia beccari tepida together with very small bolivinids (note also that the presence of a non-indigenous fauna is not excluded). The depositional environment was hypersaline, probably shallow lagoonal. A detailed discussion of the origin of these varves appears in Cita et al. (this volume).

In contrast to the varve sequence, sediments below contain a rich (or moderately abundant) and diversified normal marine planktonic and benthic foraminiferal fauna. The faunas seem to have been healthy and are devoid of dwarfed specimens. The sea depth was estimated as greater than 1500 meters from benthic foraminiferal assemblages, which differ little from those of the present-day Mediterranean, or from those in the Pliocene and Quaternary sediments.

Unit III consists of nannofossil marls to marlstones (Cores 9 through 33) and ranges in age from late Burdigalian to Serravallian (plus Tortonian according to Bizon). The sediments are stiff to hard, light bluishgray to greenish-gray. The marls are characterized by varying degrees of bioturbation. The uppermost interval between Cores 9 and 14 shows a general upward decrease in burrow traces. The conditions were normal marine throughout this stratigraphic interval. Planktonic and benthic foraminifers are common or abundant. Nannofossils are common and diversified. The marls were deposited at depths greater than 1500 meters according to analyses of benthic foraminiferal assemblages.

The absence of coarse turbidites in this unit suggests that the nearby Balearic Islands were either low-lying or completely submerged during middle Miocene time. Whether some of the marls are hemipelagic or represent distal turbidites is a question that is not resolved.

Unit IV consists mainly of mudstones of early Burdigalian age, and is 417 meters thick at the base of the drilled section. The mudstones are dark greenish and greenish-olive-gray and are rather hard. The unit was distinguished from Unit III because of its high clay content. The carbonate content, which ranges from $35 \%$ to $60 \%$ in Unit III, is about $15 \%$ to $30 \%$ in Unit IV. The presence of siliceous microfossils (Radiolaria) and opal-CT has been noted.

The planktonic and benthic foraminifers are few and are poorly preserved. The nannofossils are also less abundant and include considerable amounts of reworked species from Eocene to Cretaceous strata. Apart from the mudstones, graded beds (turbidites) were recognized in the lowest cores (44 to 46). Also present is a hard layer of sandy limestone $(>60 \%$ $\mathrm{CaCO}_{3}$ ) in Core 44. The mudstones and turbidites were deposited rapidly possibly at rates of as much as $30 \mathrm{~cm} / 10^{3} \mathrm{yr}$, and in water depths greater than 900 meters.
The presence of turbidites in the lower interval, beneath the 840-meter subbottom reflector, might suggest that the undrilled section above the basement (at about $1250 \mathrm{~m}$ subbottom) also includes turbidites deposited at a high rate of sedimentation. The earliest sediments would then probably be earliest Miocene or latest Oligocene in age.

The difference between Unit IV and Unit III is interpreted from both lithological and faunal evidence as evidence of a distinct decrease in detrital input and a suggestion of basin deepening during BurdigalianLanghian time. These changes might be related to the Burdigalian and middle Miocene transgressions of the western Mediterranean land sections. We also noted the presence of siliceous microfossils in Unit IV and their absence in Unit III, as well as differences in the nature of the planktonic foraminifer assemblages. We suspect that the faunal changes took places in response to a change in oceanographic circulation when the Mediterranean-Atlantic province became separated from the Indian Ocean by a land barrier (see Adams and Ager, 1967).

\section{Structural History of the Menorca Rise}

Hole 372 provides important information on the structural history of the Menorca margin-one of our prime objectives. It is possible now to summarize what could have been the stages in its development, using for comparison the evolutionary sequence of events established for the stable margins in different parts of the world. Our model postulates that the AlgeroProvencal Basin results from rifting, possibly initiated by drifting of microcontinents.

1) Initiation of rifting: extrapolation of the sedimentation rate curve would give an Oligocene or earliest Miocene age for the initiation of rifting.

2) Rifting phase: It is clearly shown on the seismic profiles that horst and graben tectonism was very active during the deposition (at a high sedimentation rate) of the Unit IV lower Burdigalian clayey mudstones.

3) Transgression: During late Burdigalian, Langhian, and Serravallian, sedimentation was no longer controlled by horst and graben tectonism. These formations stretch across the horst and graben structures, and they represent deposition at a decreased rate after the end of the rifting phase. The Burdigalian and Langhian transgressions have been known for some time from the study of western Mediterranean land sections.

Paleobathymetric estimates based on the analysis of benthic foraminiferal assemblages suggested that this part of the basin margin had a water depth of at least 900 meters as early as Burdigalian times. Also that water depths in excess of 1500 meters were reached during the late Burdigalian and have been maintained to the present day, except durirg the episodes of the Messinian salinity crisis. In addition to the initial subsidence associated with the rifting phase, the basin subsided due to mantle cooling and isostatic adjustment. Ryan (1976) postulated a subsidence history on the basis of a cooling model devised originally for 
ocean basins formed by sea-floor spreading. This model might not be exactly applicable to the Balearic Basin. The present high heat-flow values suggest that the mantle cooling may have started long after the birth of the basin. The deposition of thick salt accumulations in a pre-existing basin must also have induced isostatic subsidence. Finally, the question of isostatic changes associated with a desiccated and resubmerged deep basin has been examined by Le Pichon et al. (1971). The Plio-Quaternary subsidence of the Balearic Basin might be related not only to mantle cooling, but also the load of water flooding a desiccated deep basin (Hsü et al., 1973).

The Messinian evaporite deposition corresponds to an event completely different from the evaporite deposition commonly associated with the rifting phase of stable margins. On the Menorca Rise this type of evaporite deposit should be of Oligocene or earliest Miocene age. Its existence has not been verified, but is suggested by the downward increase of salinity of interstitial waters in lower Miocene sediments here (McDuff and Gieskes, this volume).

A significant conclusion reached by the shipboard party was that the Balearic Basin was already in existence prior to the Messinian salinity crisis. None of us hold the viewpoint that the Balearic Basin was a broad shelf sea of the Baltic type prior to the Messinian salinity crisis, nor do we advocate that the present Balearic Basin owed its origin to a Plio-Quaternary foundering (Hsü et al., this volume).

\section{Heat Flow}

Shipboard thermal conductivity data and four downhole temperature measurements were made between 105.0 and 155.0 meters subbottom in an offset hole $(372 \mathrm{~A})$ drilled at this site. They were used to calculate a highly reliable value of $2.46 \pm 0.16 \mathrm{cal} /$ $\mathrm{cm}^{2} \mathrm{sec}$ for heat flow through the sea floor. This value is in excellent agreement with the mean of 25 other western Mediterranean heat-flow values obtained using conventional oceanographic techniques which are generally high $\left(2.33 \pm 1.01 \mathrm{cal} / \mathrm{cm}^{2} \mathrm{sec}\right)$, thus confirming their geophysical significance (Erickson, 1970). The high heat-flow in the western Mediterranean supports geotectonic theories that the entire area is geologically young and was (or still is being) created as a result of thermally driven processes in the upper mantle. For additional details see (Erickson and Von Herzen, this volume).

\section{REFERENCES}

Adams and Ager, 1967. Aspects of Tethyan biogeography: Syst. Assoc. Publ. No. 7.

Biju Duval, B., Letouzey, J., Montadert, L., Courrier, P., Mugniot, J. F., and Sancho, J., 1974. Geology of the Mediterranean Sea Basins. In Burk, C .A. and Drake, C. L. (Eds.), Geology of continental margins: New York (Springer Verlag), p. 695-721.

Bizon, G., and Bizon J. J., 1972. Atlas des principaux foraminiferes planctoniques du Bassin mediterranéen (Oligocène á Quaternaire): Technip, Paris, p. 1-316.

Blow, W. A., 1969. Late middle Eocene to Recent planktonic foraminiferal biostratigraphy: Proc. First Intern. Conf.
Plankt. Microfossils, Geneva, 1967, v. 1, Leiden (Brill), p. 199-422.

Bolli, H. M., 1962. Globigerinopsis, a new genus of the foraminiferal family Globigerinidae: Ecolog. Geol. Helv., v. 55 , p. $281-284$.

1966. Zonation of Cretaceous to Pliocene marine sediments based on planktonic foraminifera: Asoc. Venez. Geol. Min. Petrol., Bol. Inform., v. 9, p. 3-32.

Ciaranfi, N. and Cita, M. B., 1972. Paleontological evidence of changes in the Pliocene climate. In Ryan, W. B. F., Hsü, K. J., et al., Initial Reports of the Deep Sea Drilling Project, Volume 13: Washington (U.S. Government Printing Office), p. 1387-1399.

Cita, M. B., 1973. The Pliocene record in deep-sea Mediterranean sediments. 1. Pliocene biostratigraphy and chronostratigraphy. In Ryan, W. B. F., Hsü, K. J., et al., Initial Reports of Deep Sea Drilling Project, Volume 13: Washington (U.S. Government Printing Office), p. 1343-1379.

1975. Planktonic foraminiferal biozonation of the Mediterranean Pliocene deep-sea record. A revision: Riv. Ital. Pal. Strat., v. 81, p. 527-544.

Cita, M. B. and Mazzola, G., 1970. Globigerinopsoides gen. n. from the Miocene of Algeria: Riv. Ital. Pal. Strat., v. 76, p. 465-476.

Erickson, A. J., 1970. The measurement and interpretation of heat flow in the Mediterranean and Black Seas, Ph.D. thesis, M.I.T., Cambridge, Massachusetts.

Giannelli, L. and Salvatorini, G., 1975. I foraminiferi planctonici dei sedimenti dell'arcipelago maltese. II Biostratigrafia di "Blue Clay," "'Greensand," e "Upper Coralline Limestone,”: Atti Soc. Tosc. Sci. Nat., v. 82, p. 1-24.

Hsü, K. J., Ryan, W. B. F., and Cita, M. B., 1973. Origin of the Mediterranean Evaporite. In Ryan, W. B. F., Hsü, K. J., et al., Initial Reports of the Deep Sea Drilling Project, Volume 13: (U.S. Government Printing Office), p. 12031231. Washington.

Le Pichon, X., Pautot, G., Auzende, J. N., and Oliver, J. L., 1971. La Mediterranee occidentale depuis l'oligocene, Schema d'evolution: Earth Planet. Sci. Lett., v. 13, p. 145152.

Mauffret, A., Fail, J. P., Montadert, L., Sancho, J., and Winnock, E., 1973. Northwestern Mediterranean sedimentary basin from seismic reflection profile: Am. Assoc. Petrol. Geol. Bull., v. 57, p. 2245-2262.

Ogniben, L., 1957. Petrographic della serie solifera Siciliana e considerazionio geologische relative: Mem. Descr. Carta, Geol. Italia, v. 33, p. 275.

Rouchy, M. J-M., 1976. Mise en évidence de nannoplancton calcaire dans certains types de gypse finement lité (balatino) du Miocène terminal de Sicile et conséquences sur la genèse des évaporites méditerranèenes de cet age: $\mathrm{C}$. R. Acad. Sci. Paris, v. 282, p. 13-16.

Ryan, W. B. F., 1976. Quantitative evaluation of the depth of the Western Mediterranean before, during and after the late Miocene Salinity crisis: Sedimentology, v. 23, p. 791813.

Ryan, W. B. F., Cita, M. B., Dreyfus Rawson, M., Burckle, L. H., and Saito, T. 1974. A paleomagnetic assignment of Neogene state boundaries and the development of isochronous datum planes between the Mediterranean, the Pacific and Indian Oceans in order to investigate the response of the World Ocean to the Mediterranean "Salinity Crisis". Riv. Ital. Pal. Strat., v. 80, p. 631-688.

Ryan, W. B. F., Hsü, K. J., et al., 1973. Initial Reports of the Deep Sea Drilling Project, Volume 13: Washington (U.S. Government Printing Office). Schreiber, C. G., Friedman, G. M., Decima, A., and Schreiber, E., in press. The depositional environments of the upper Miocene (Messinian) Evaporite deposits of the Sicilian Basin: Sedimentology. 


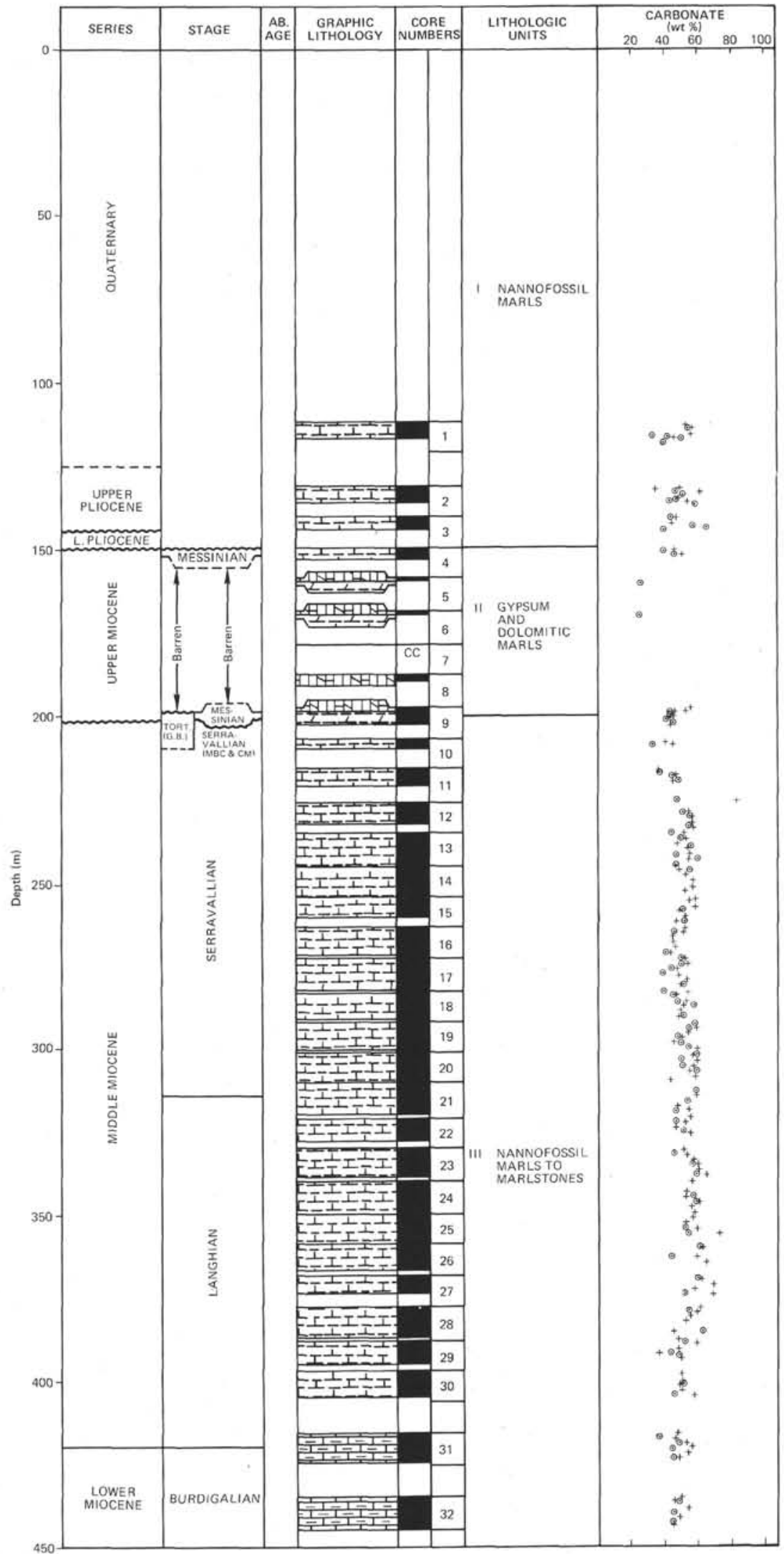




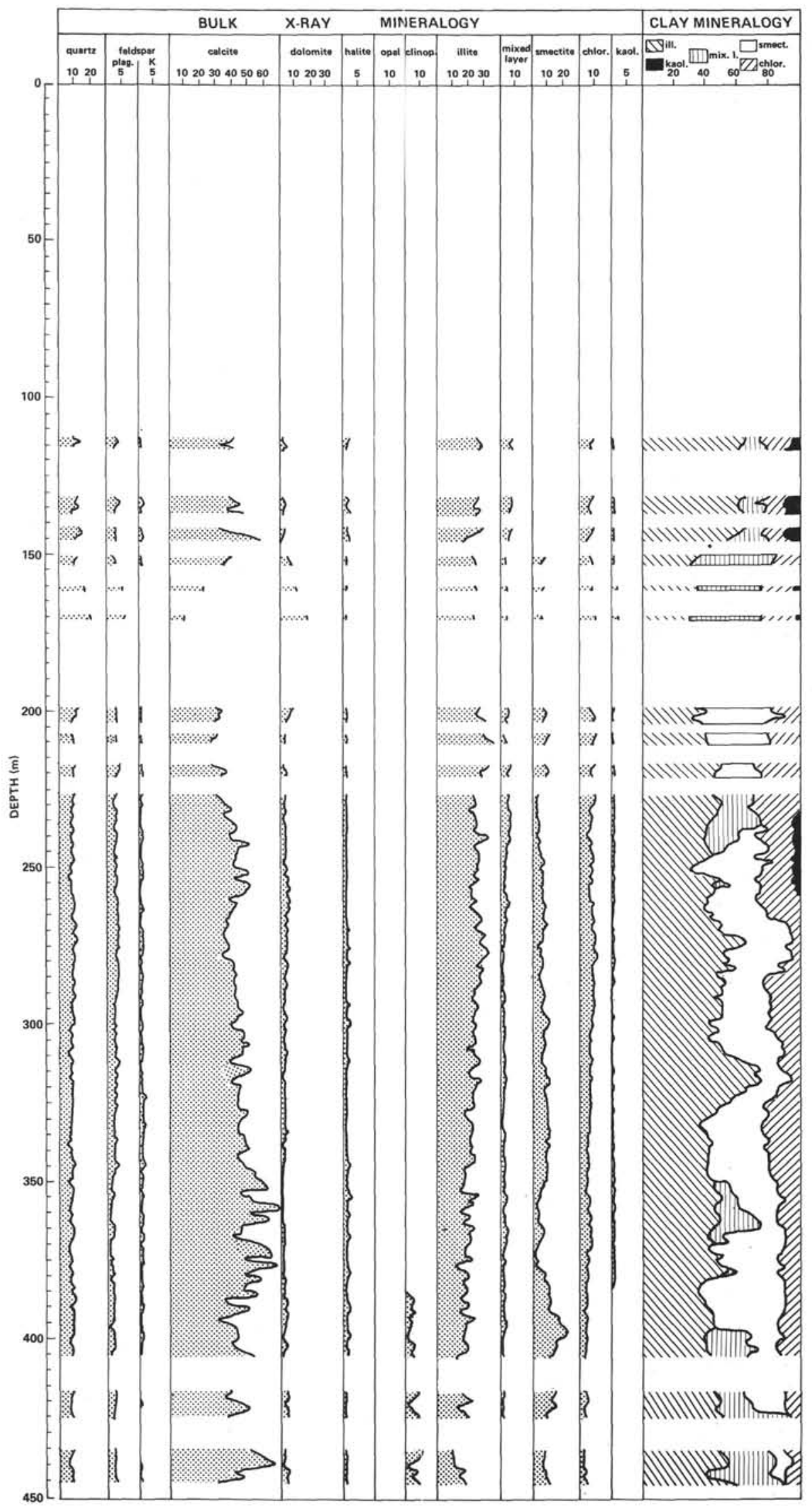




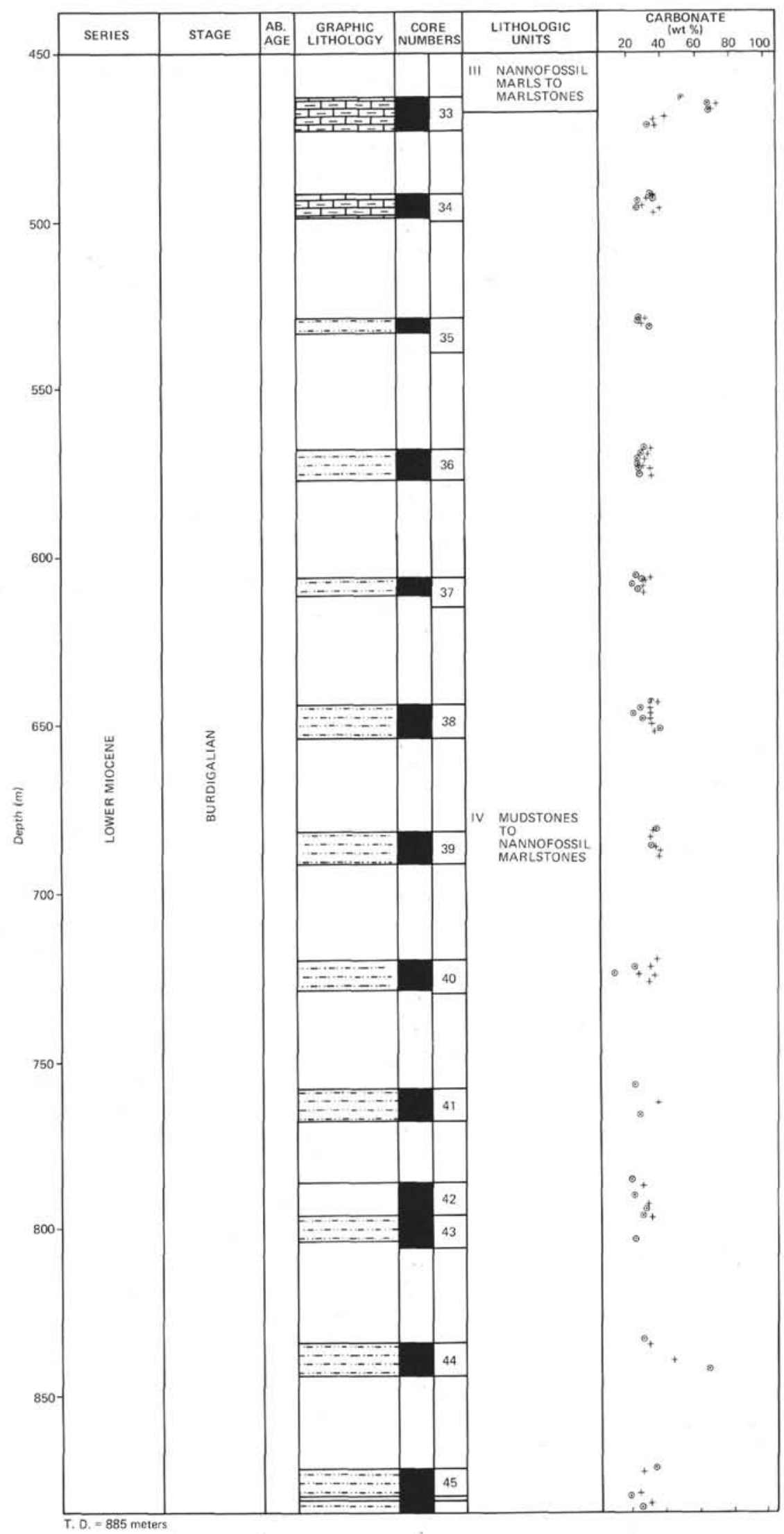




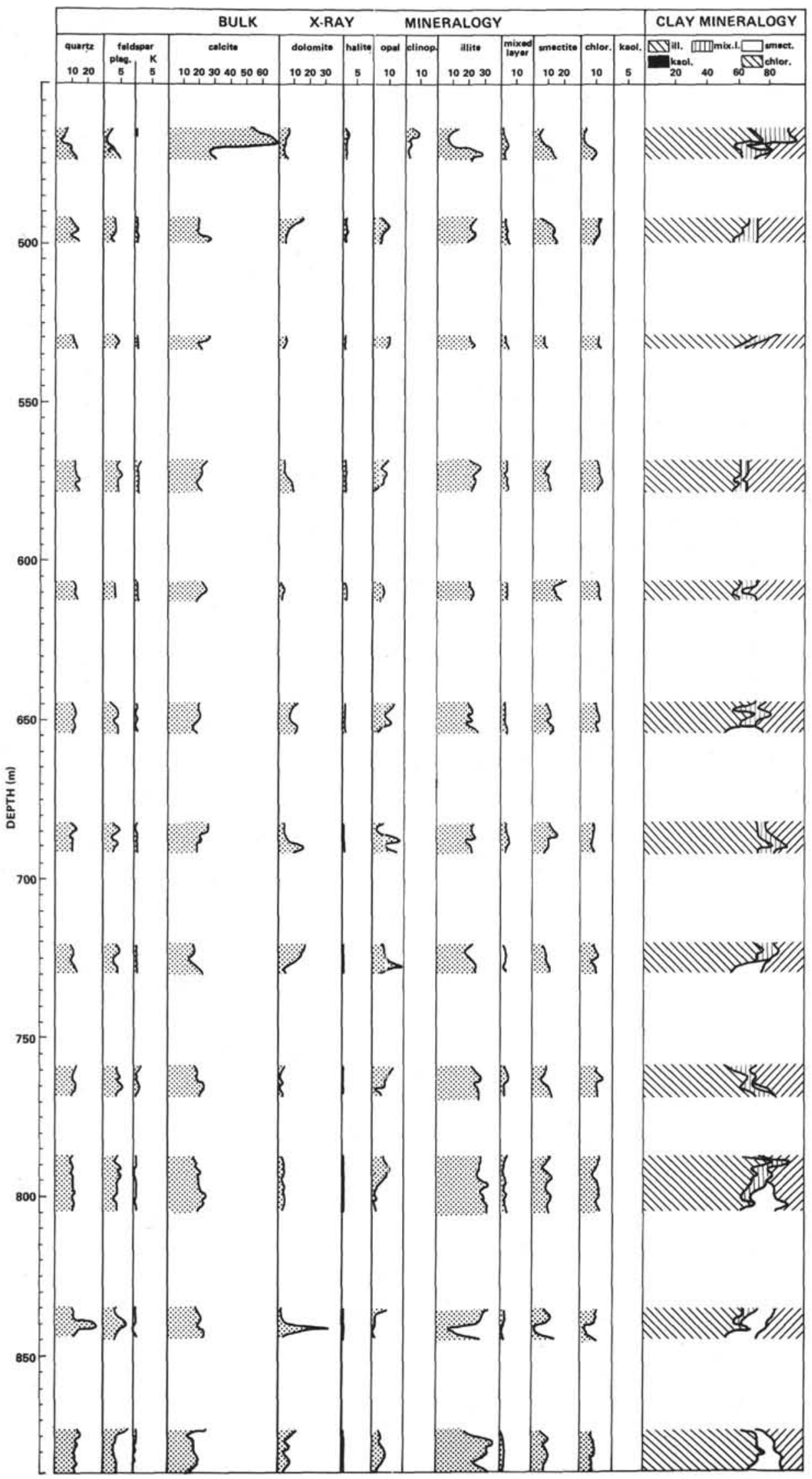




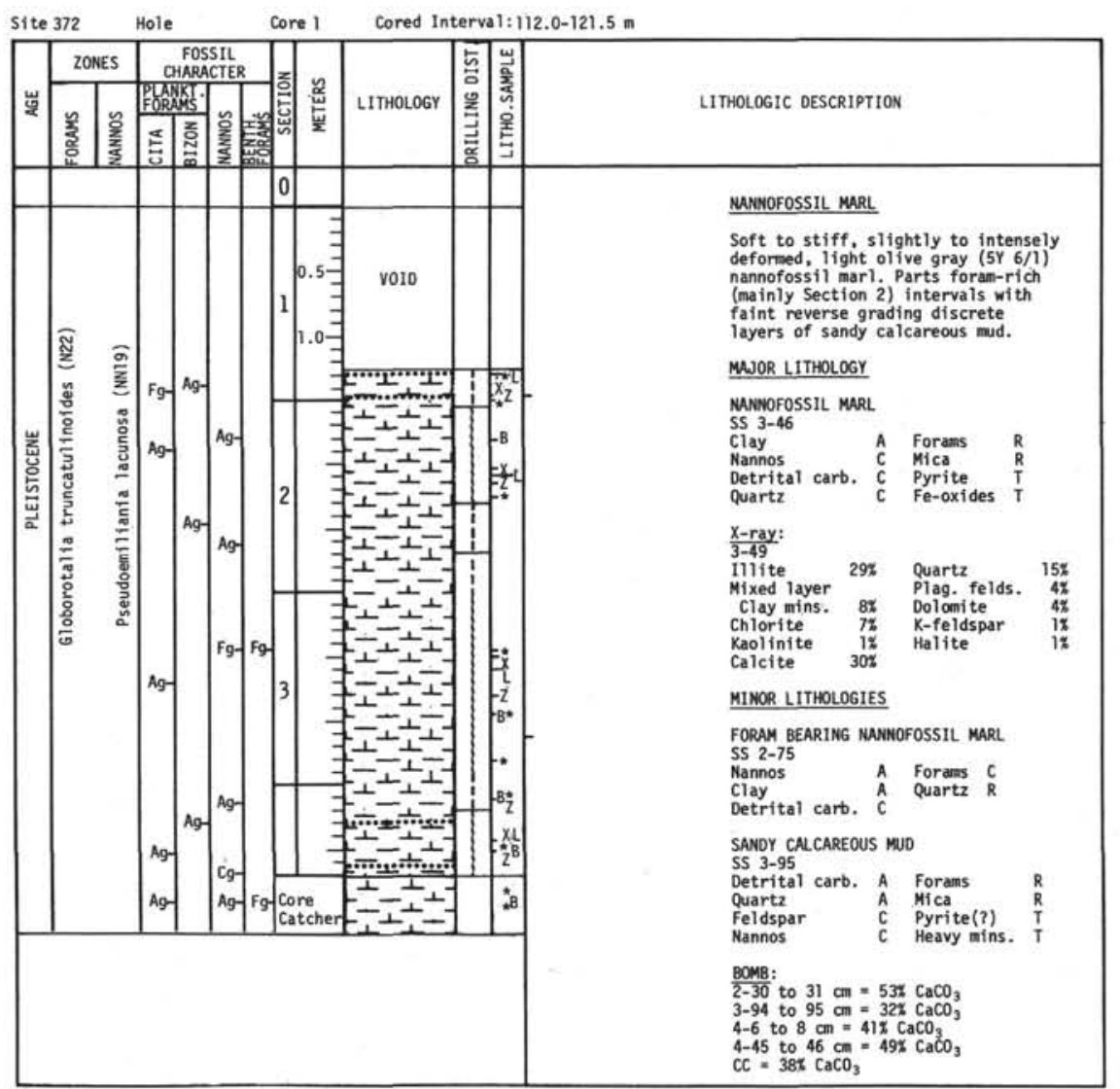

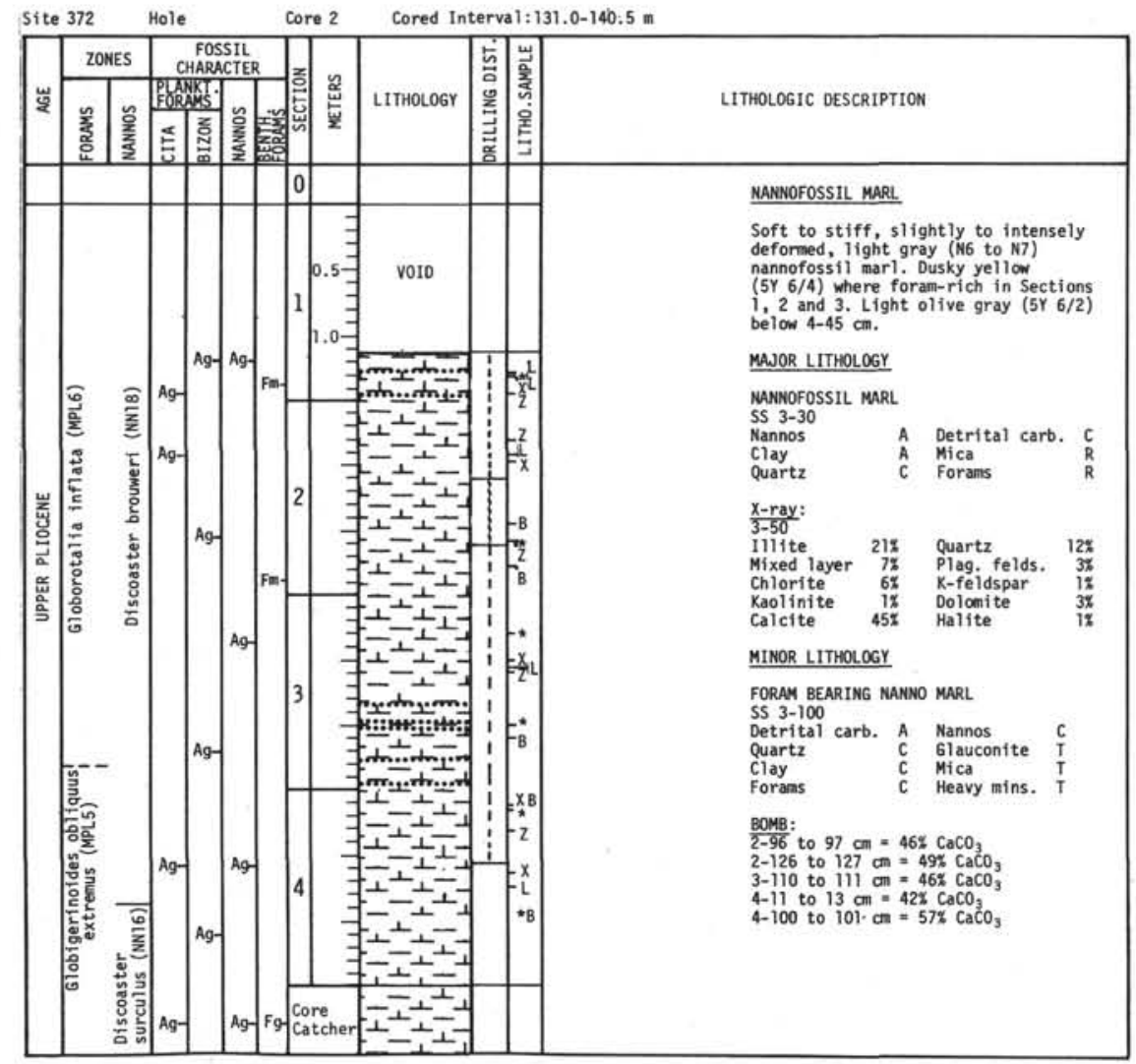




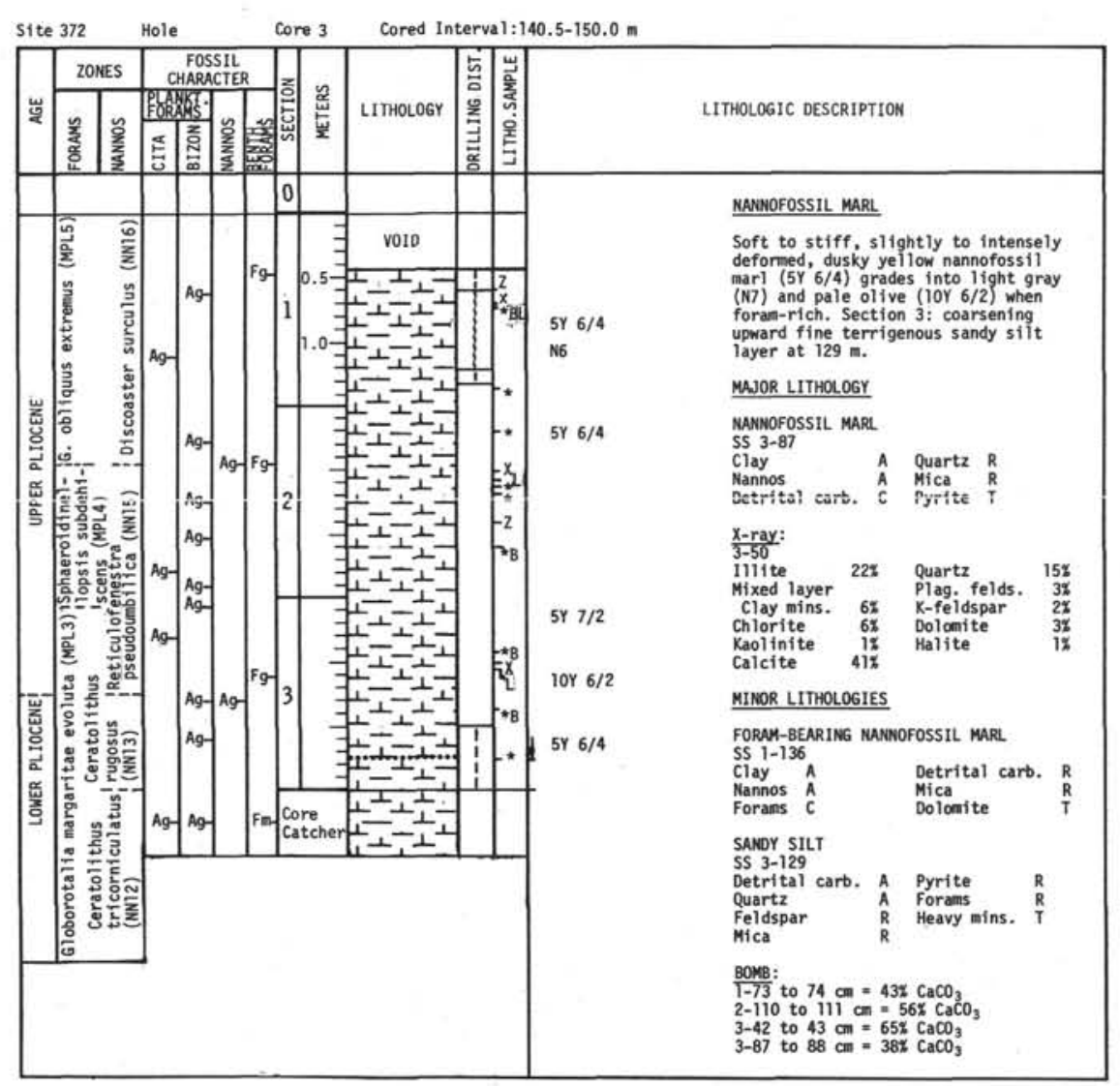

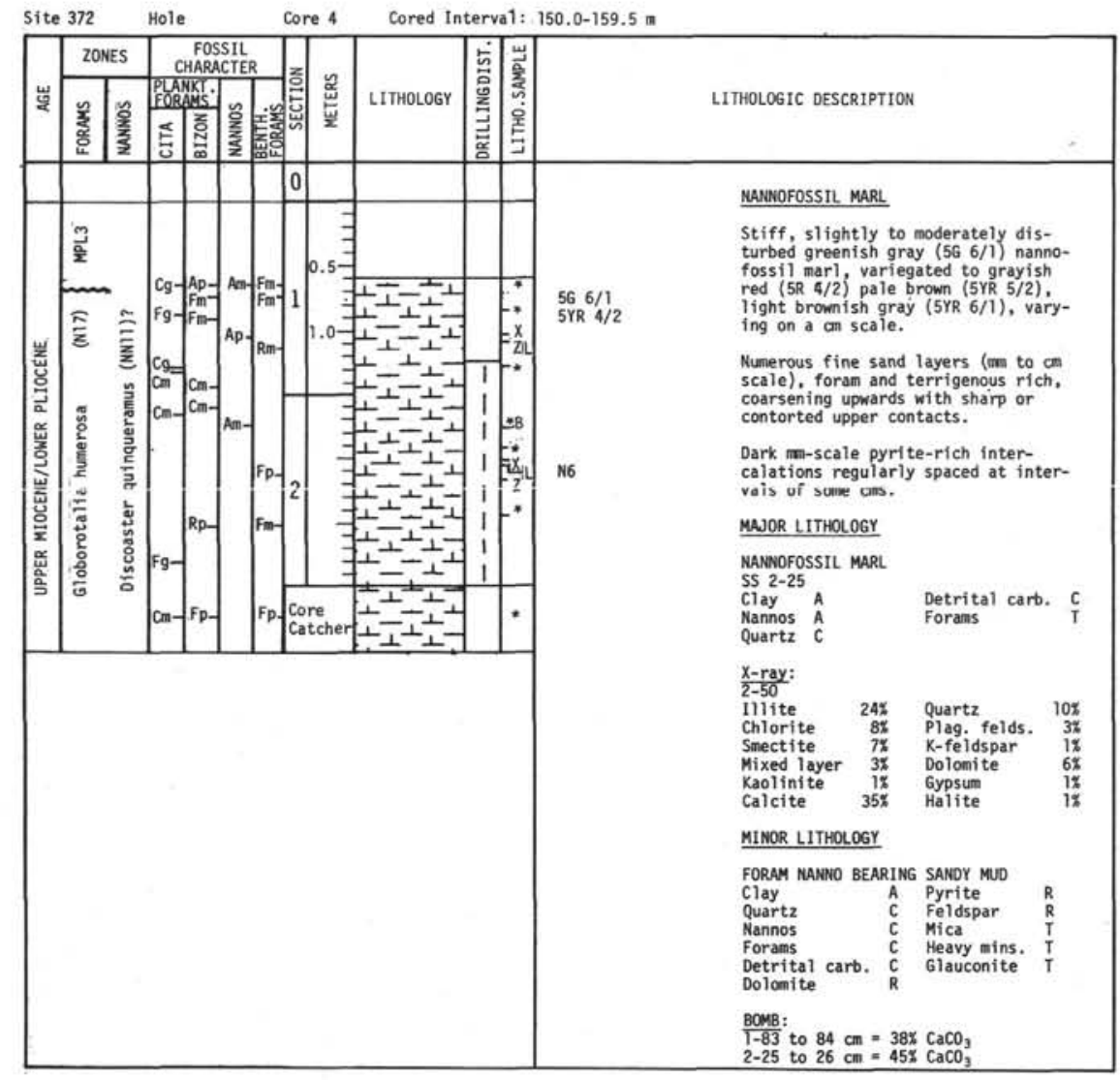




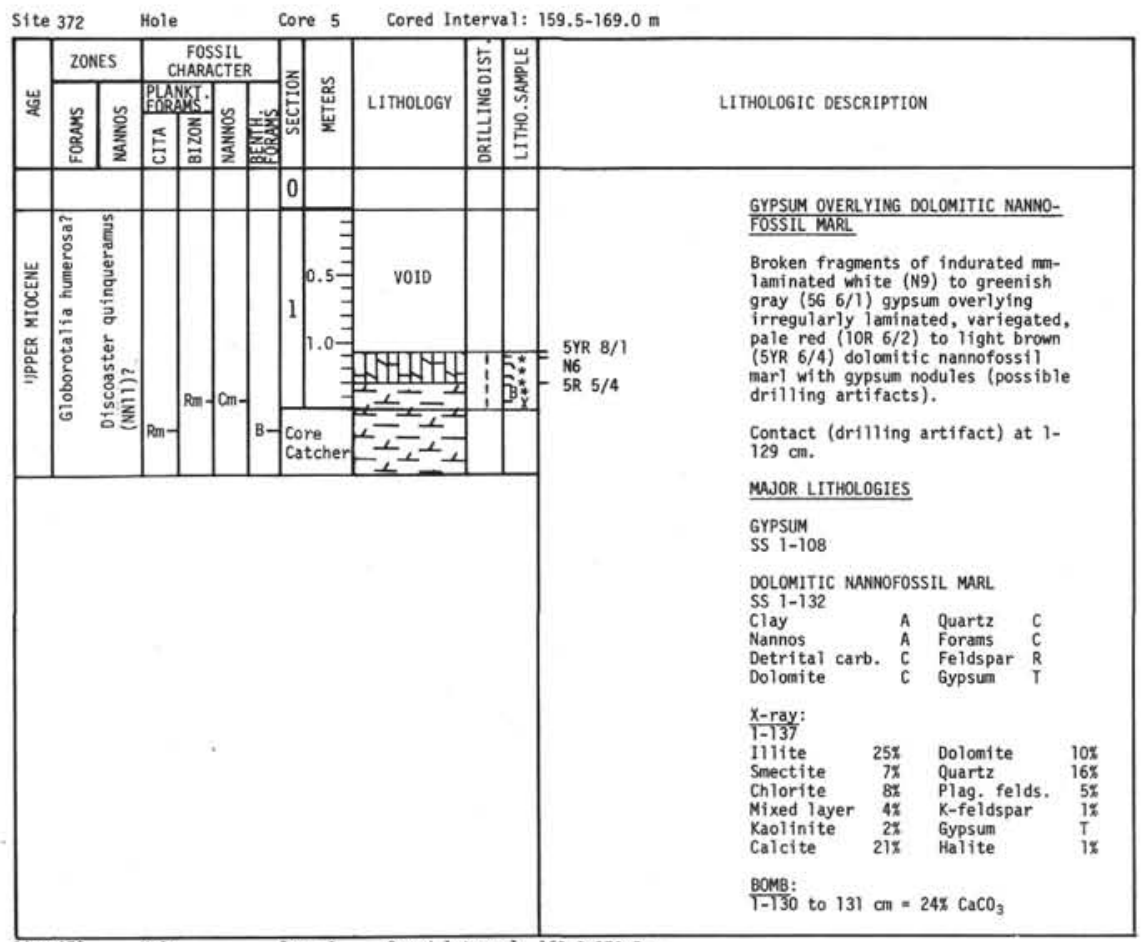

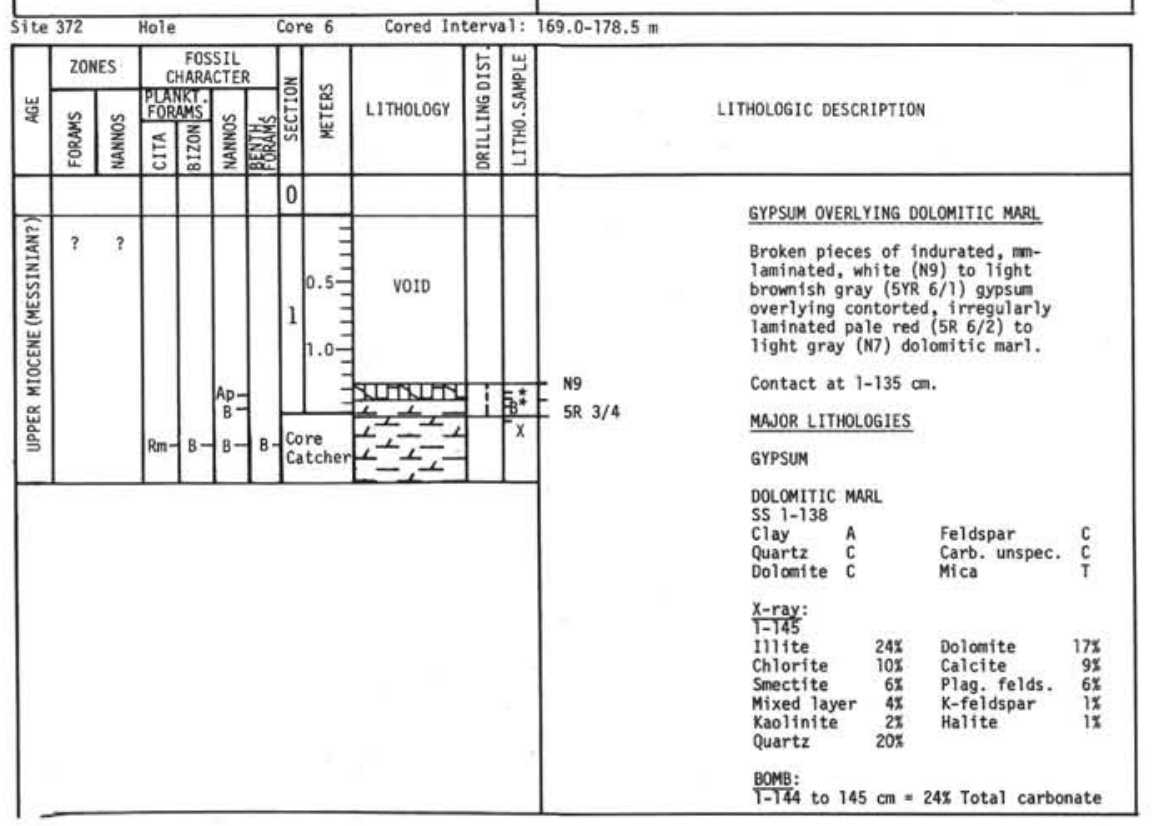
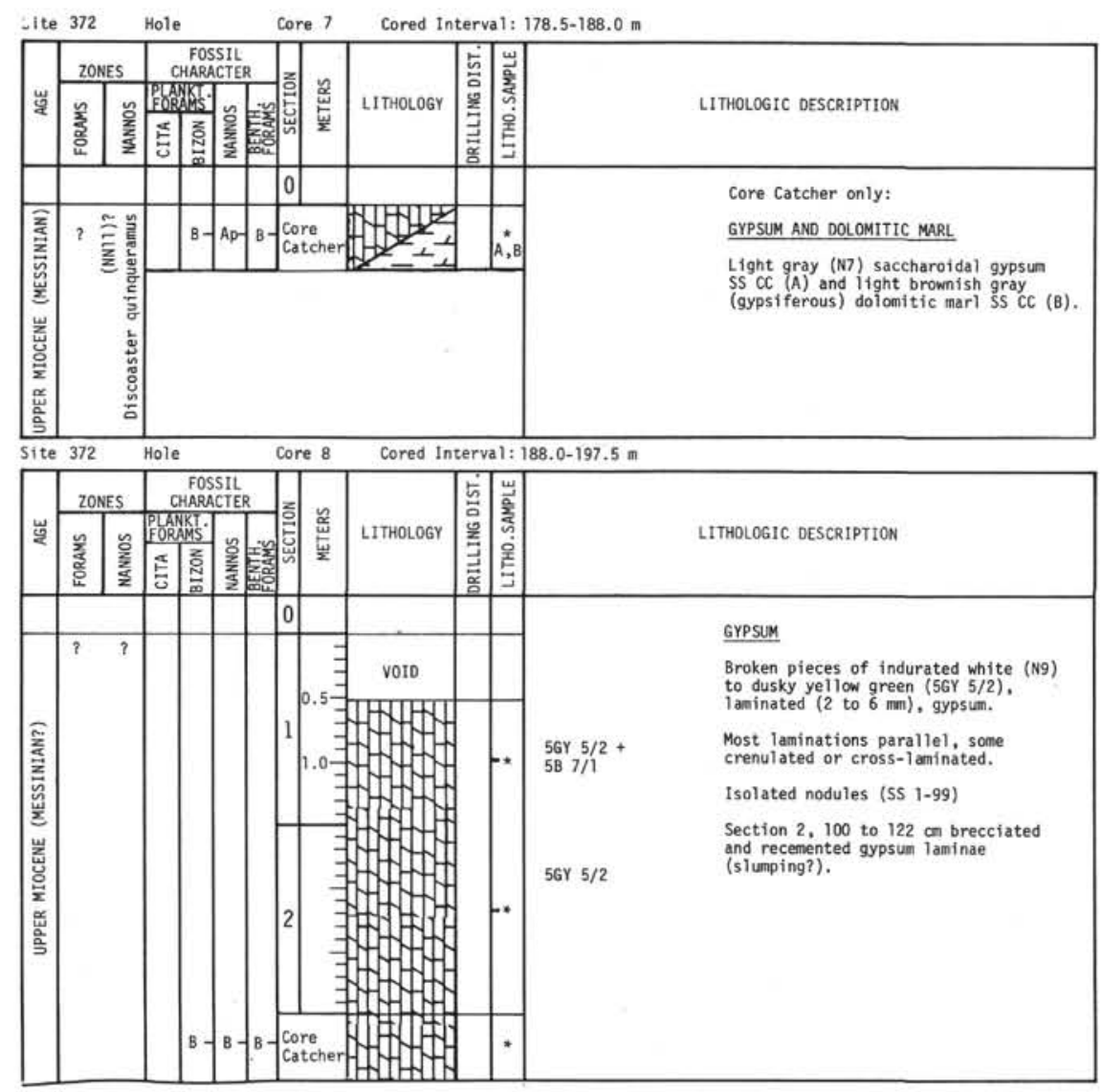


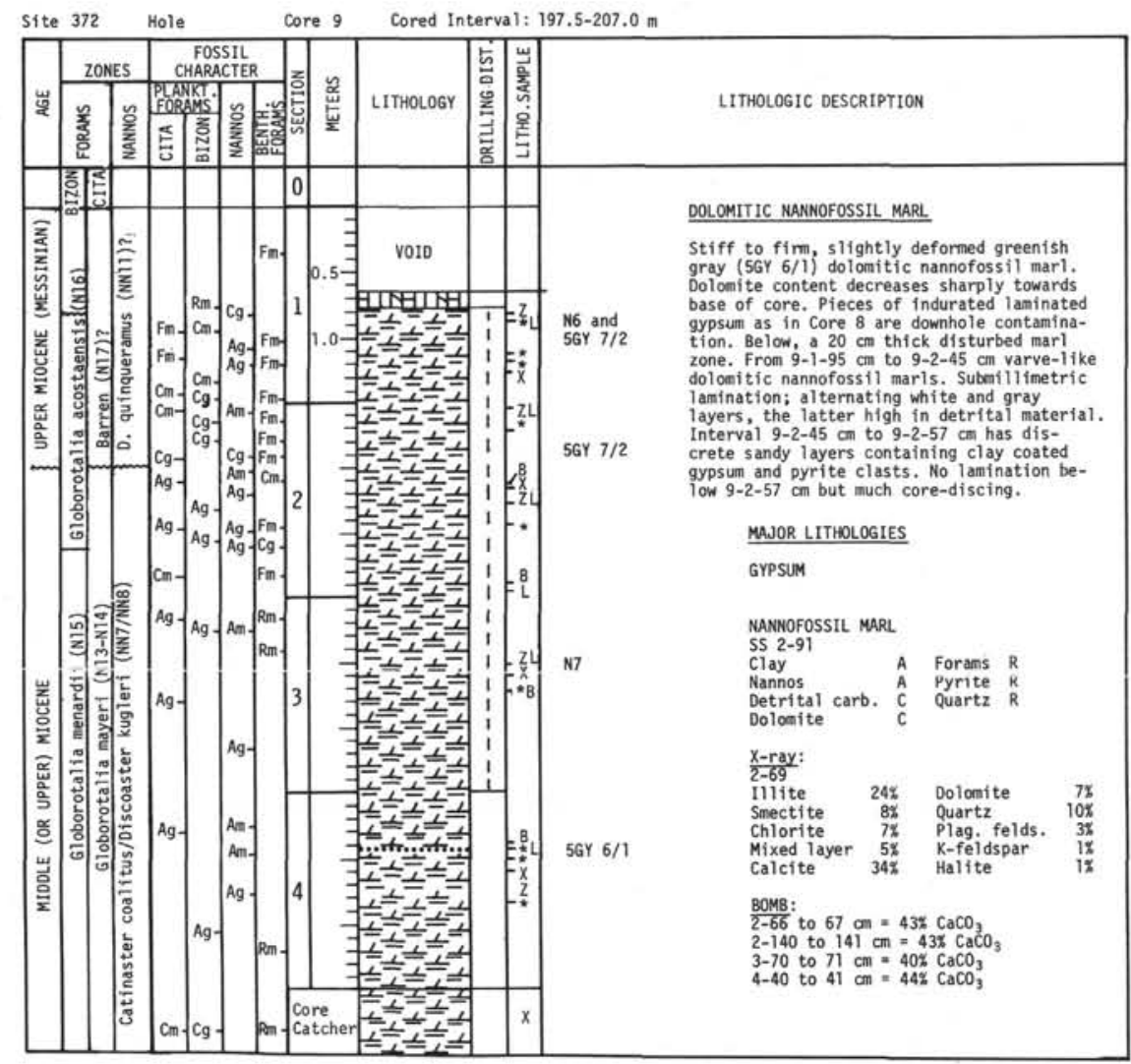

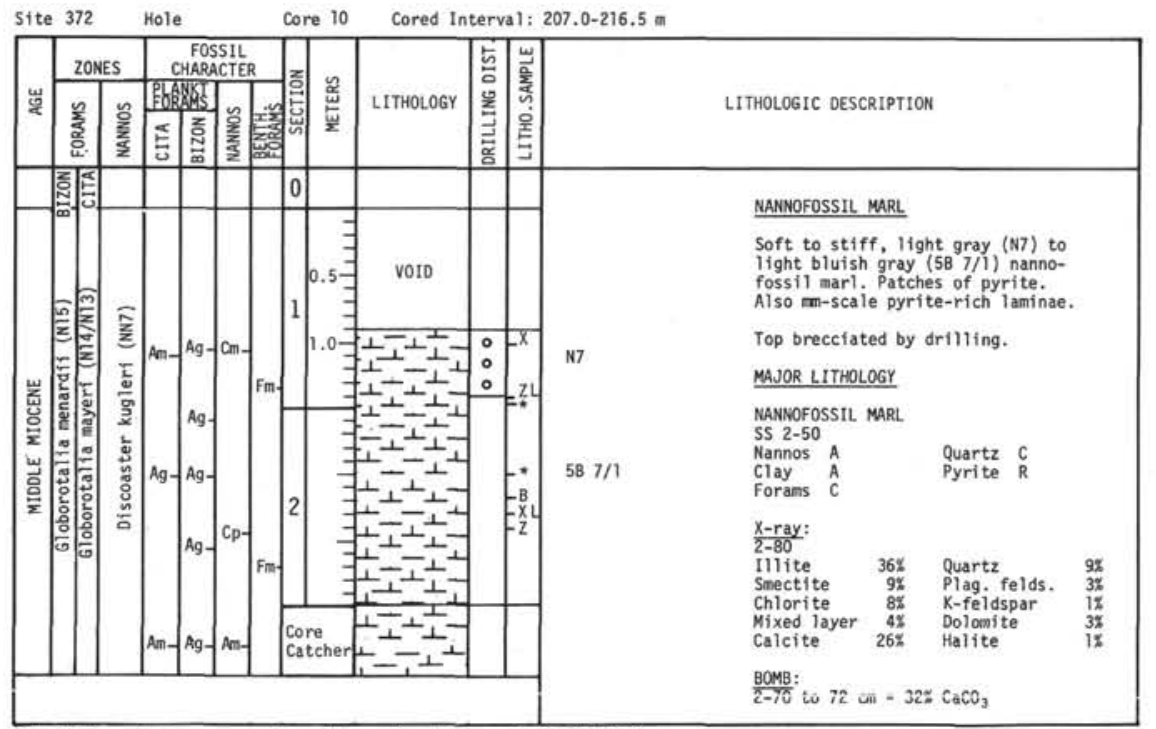

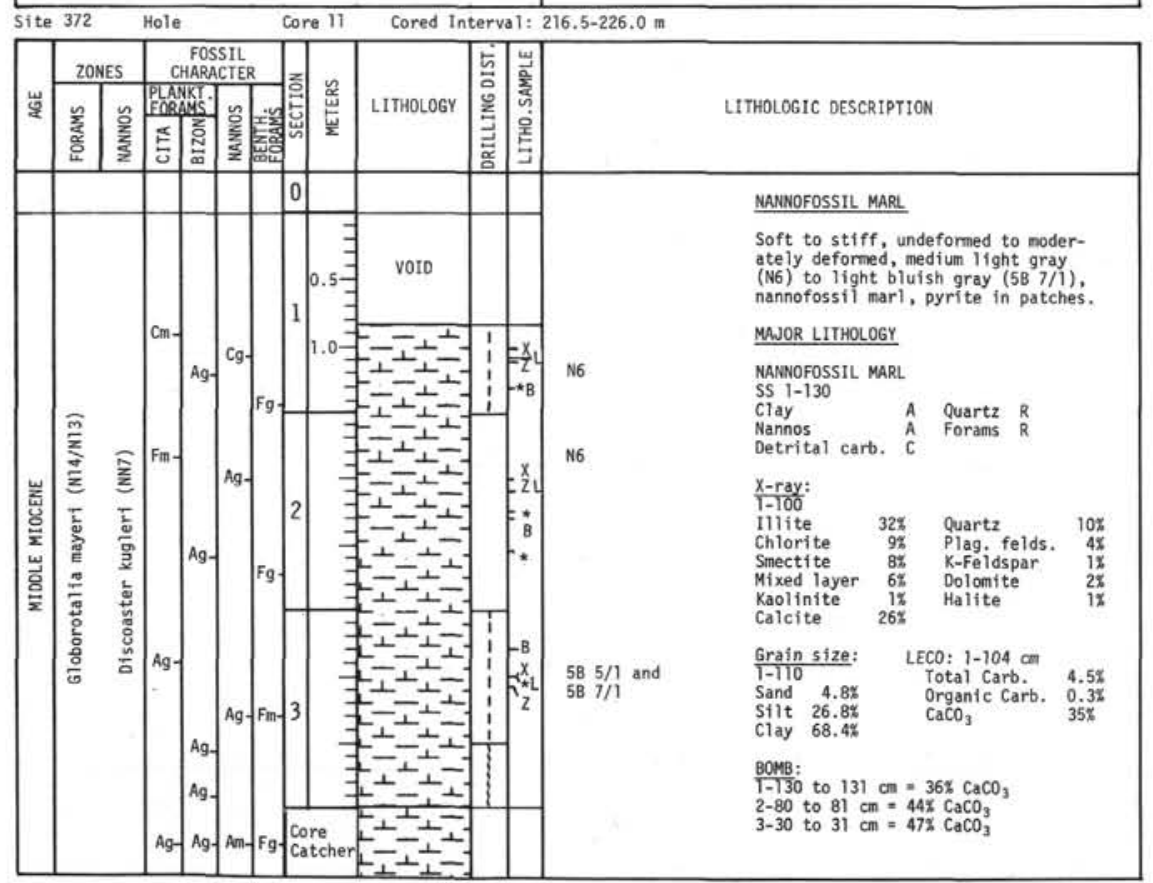



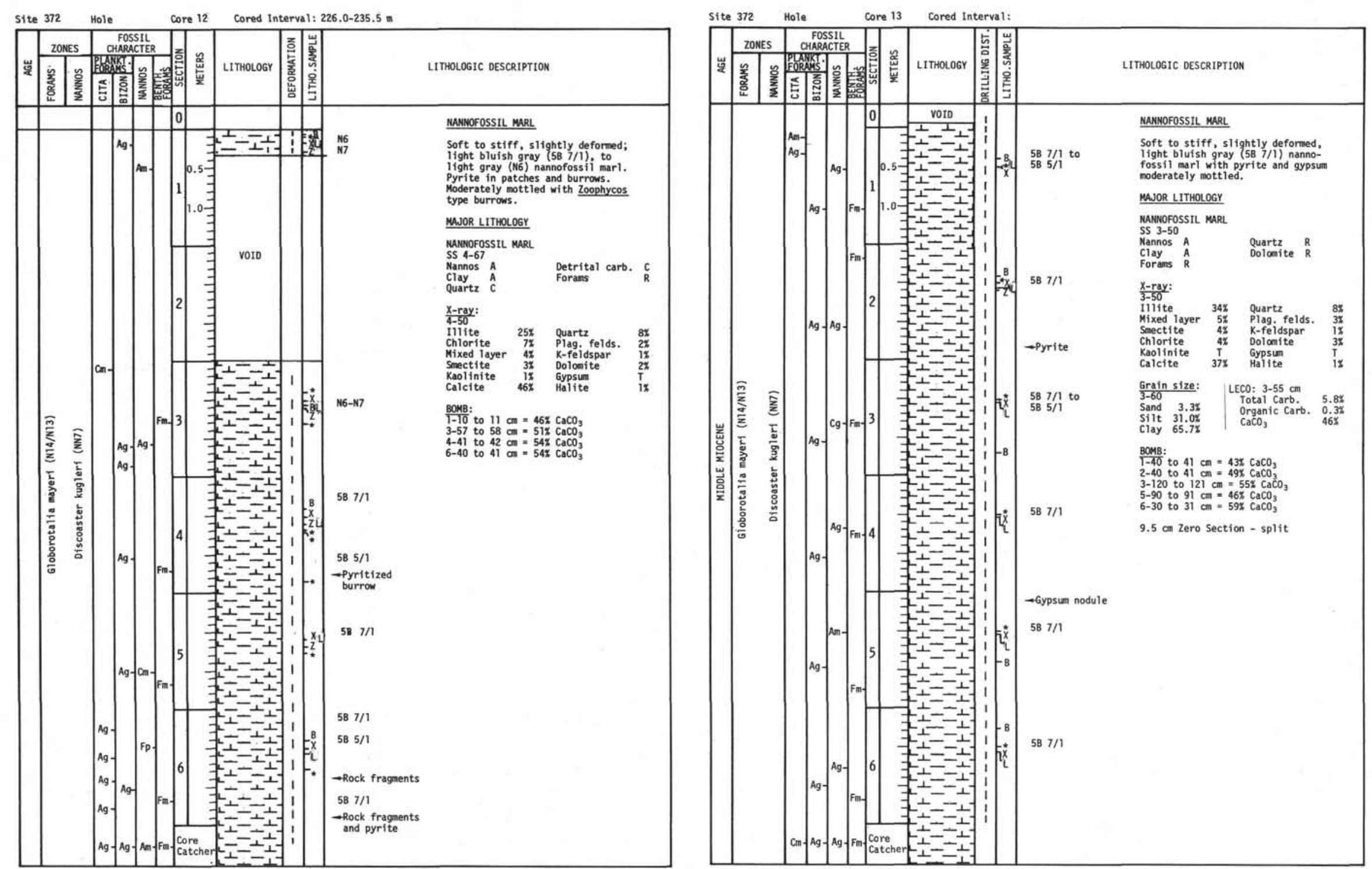

$\begin{array}{ll}\text { Nannos A } & \text { Detrital carb. } \\ \text { Clay } & \text { F } \\ \text { Clarams } & \end{array}$

$\frac{x-r a y}{4-50}$

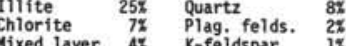

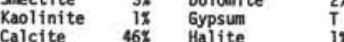

BOAB:

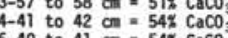

NAANOFOSSIL MARL

tiff, slightly deformed; 

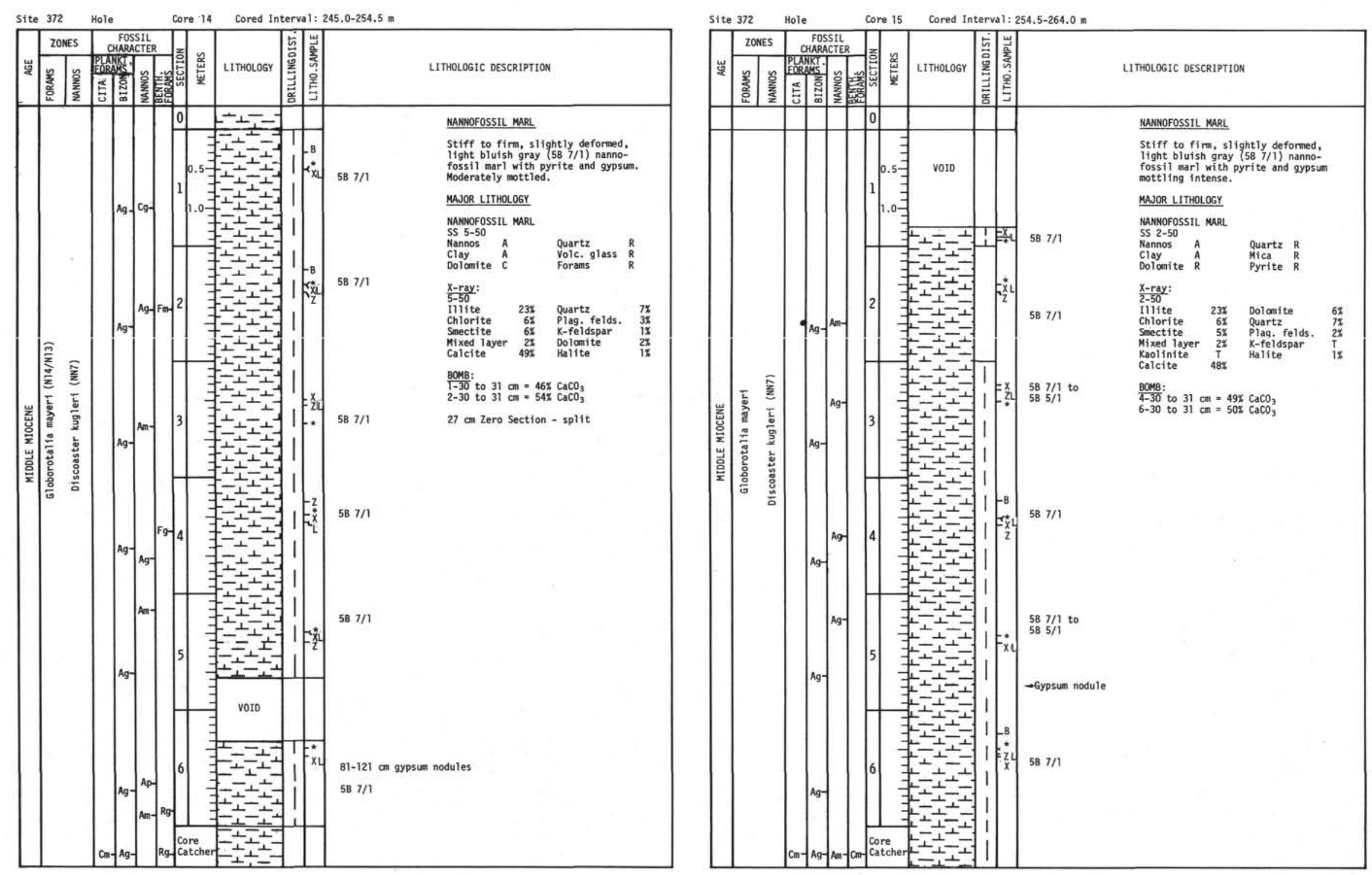

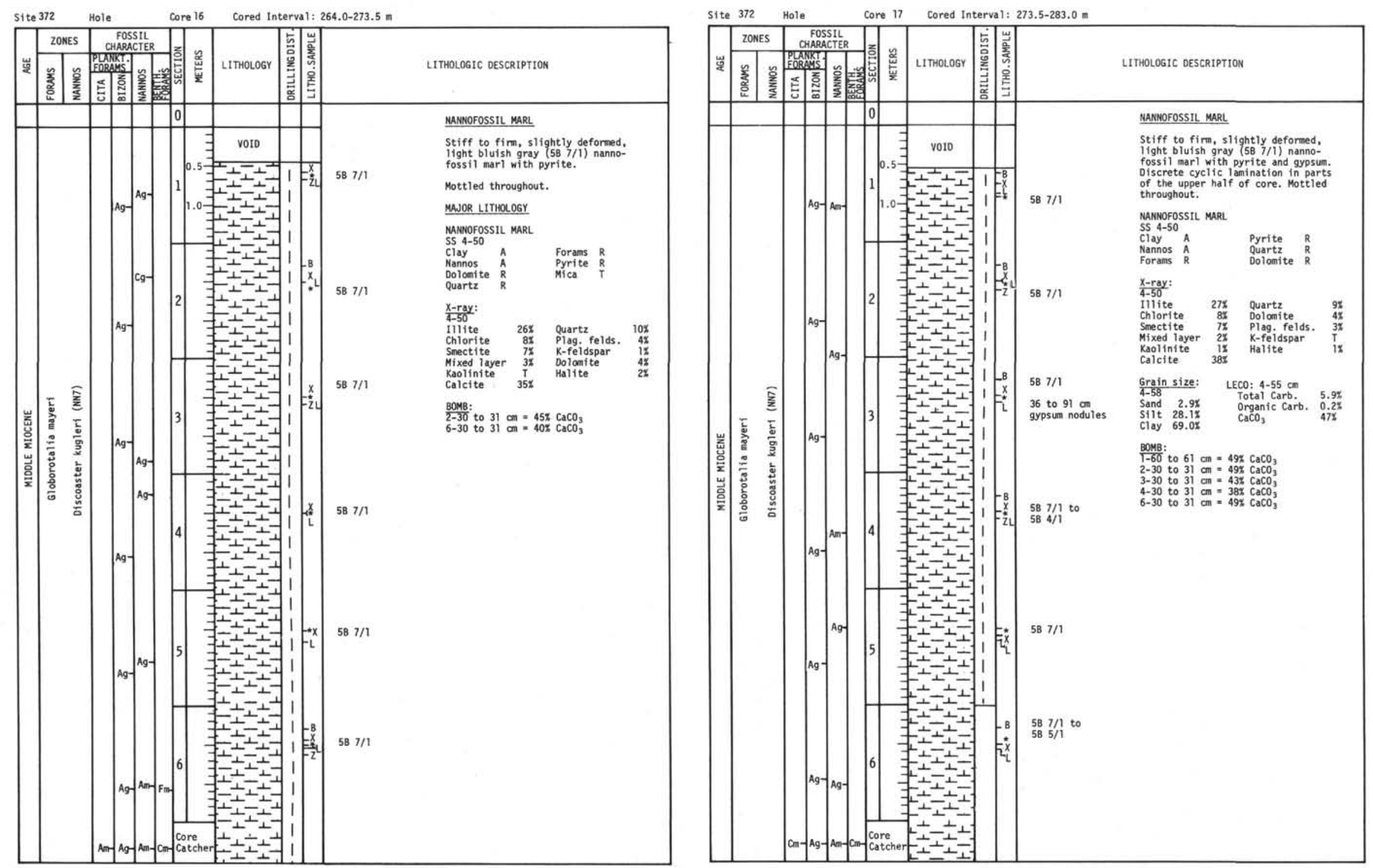

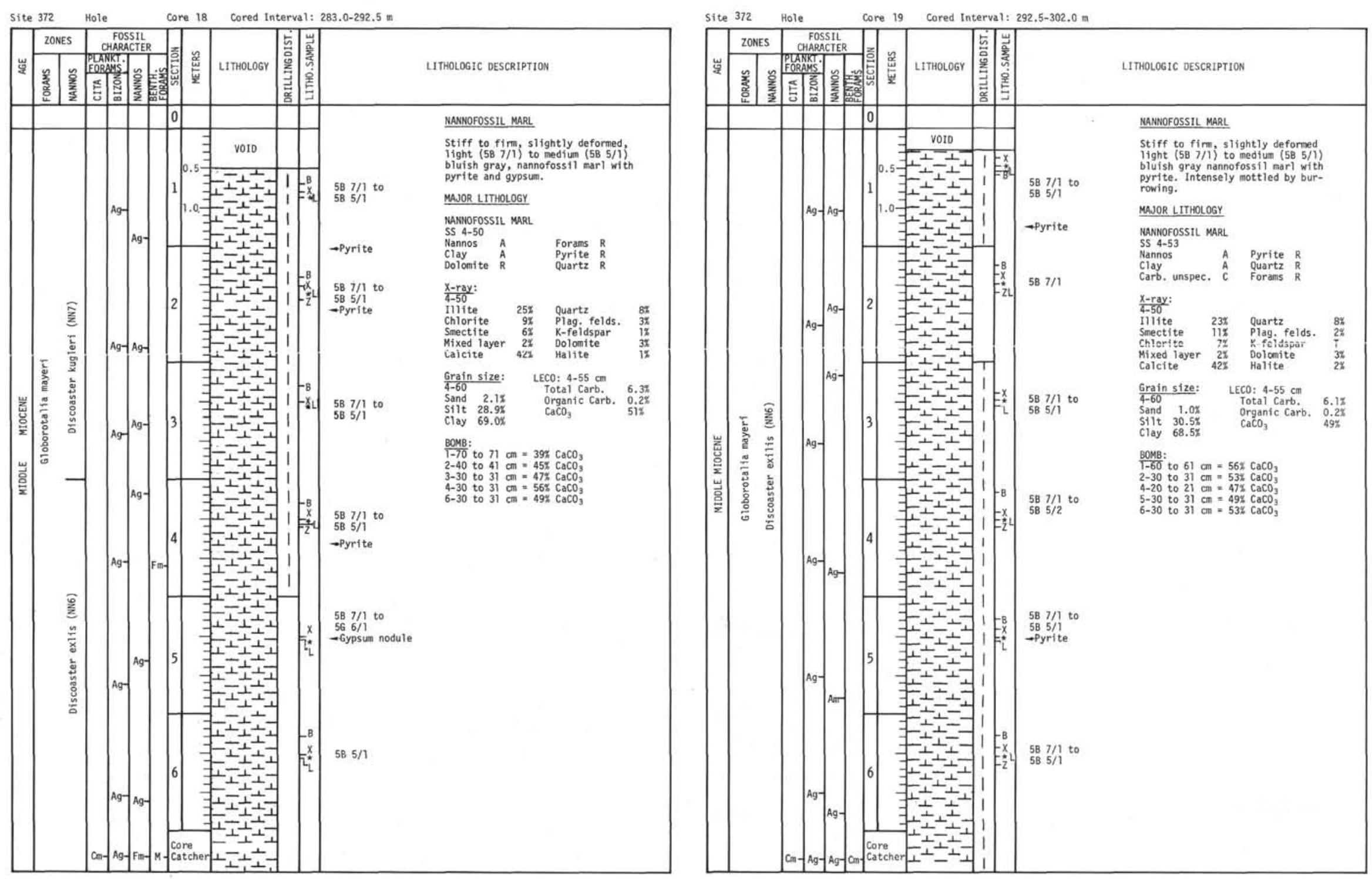
$\overline{8}$

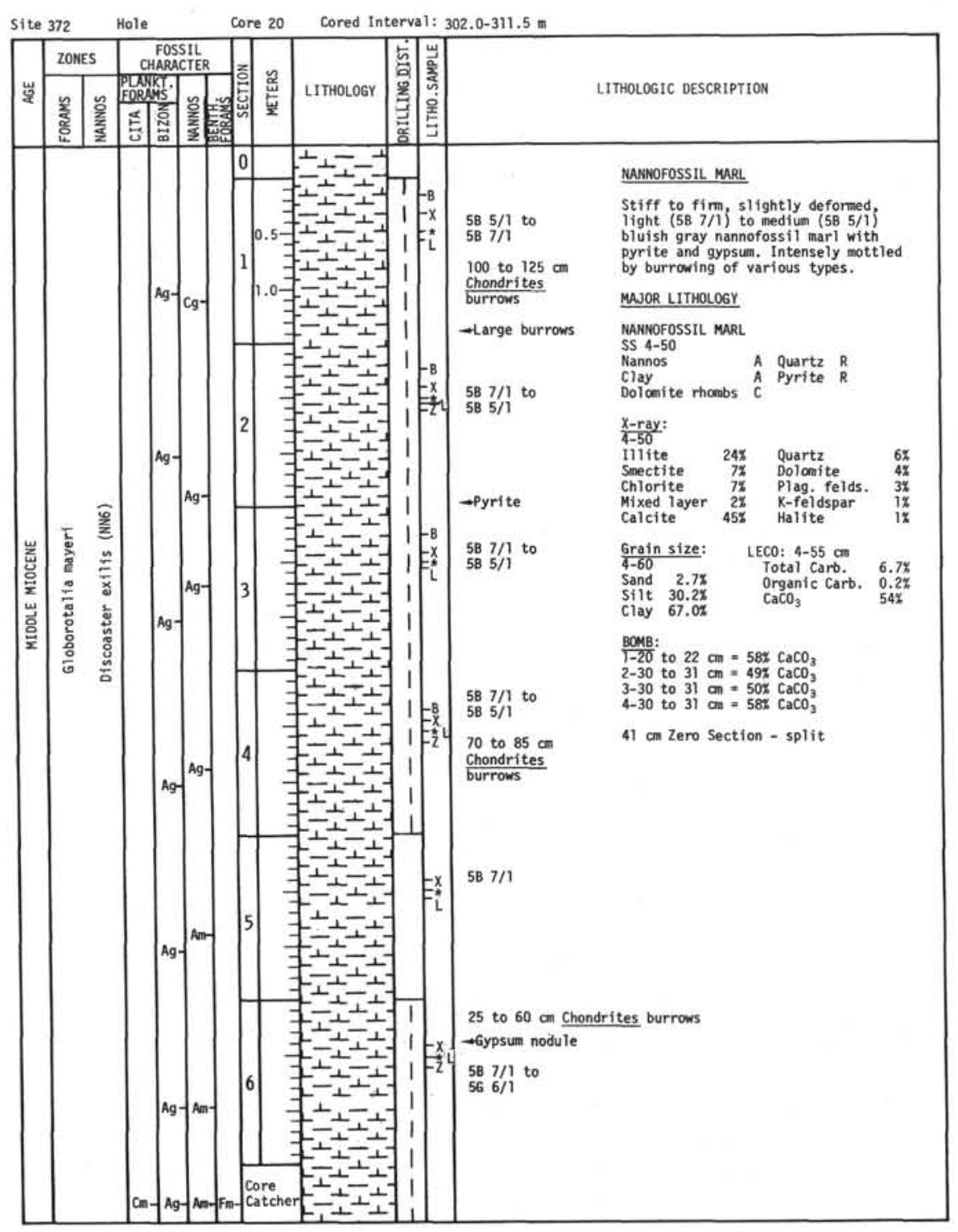

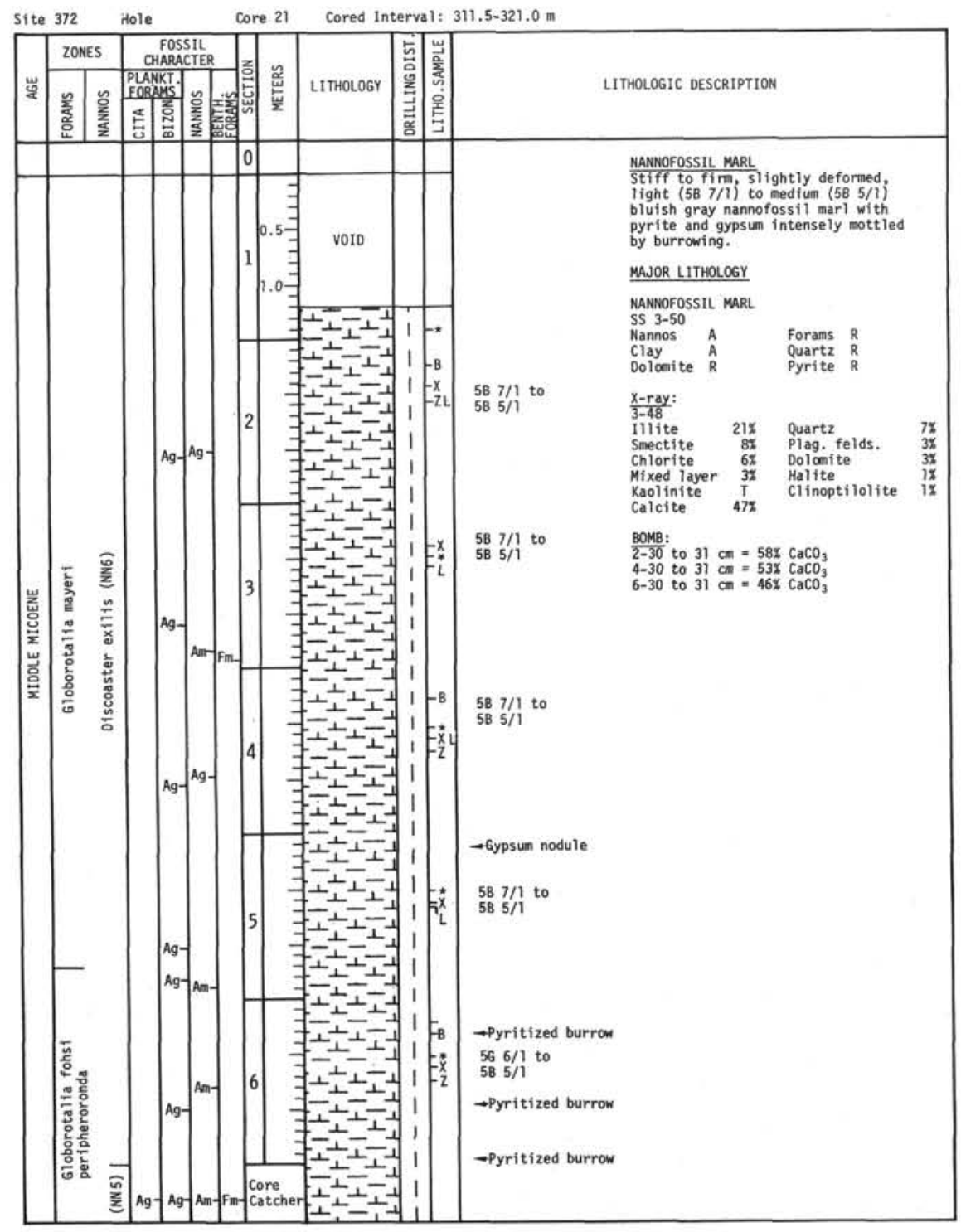



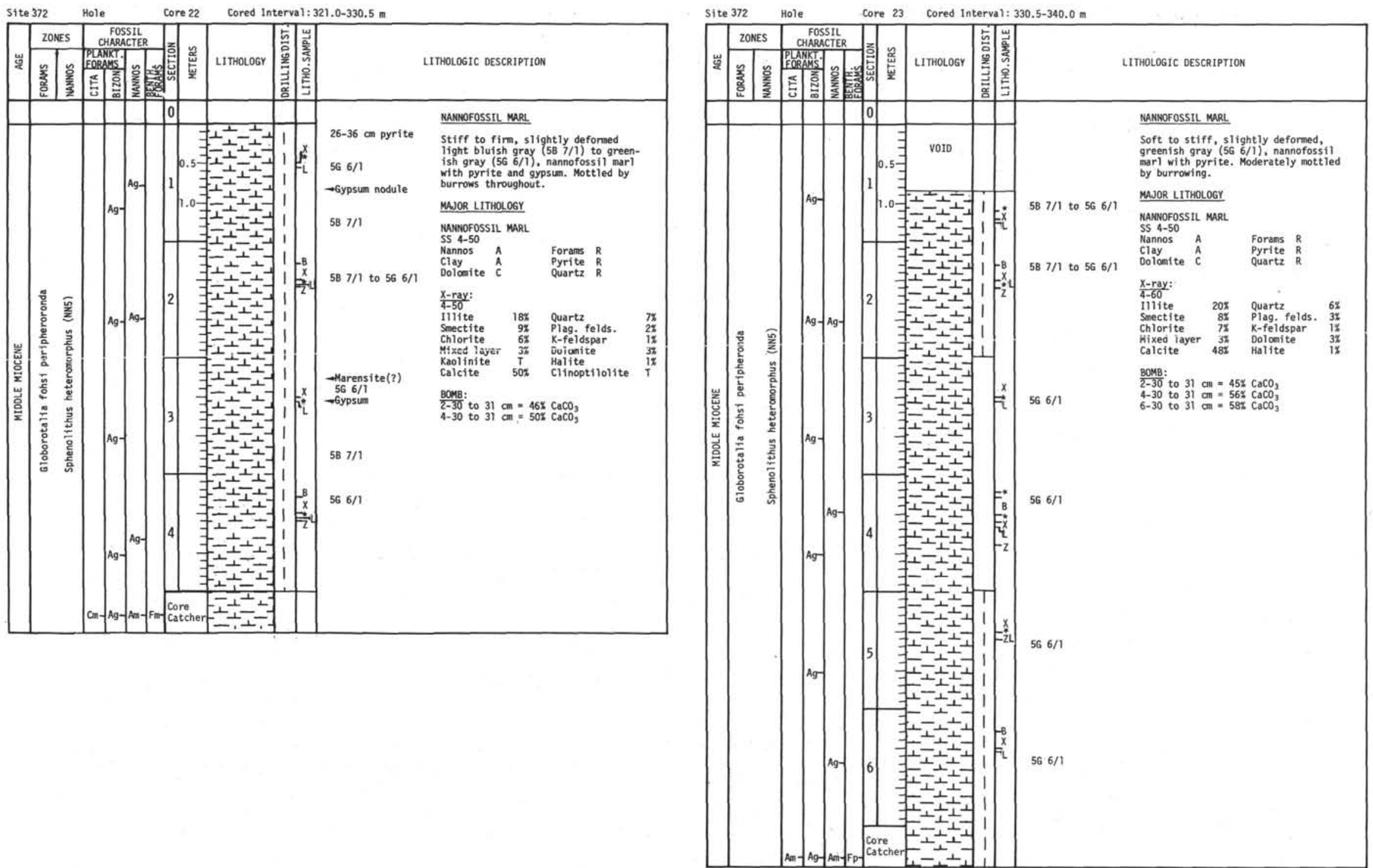

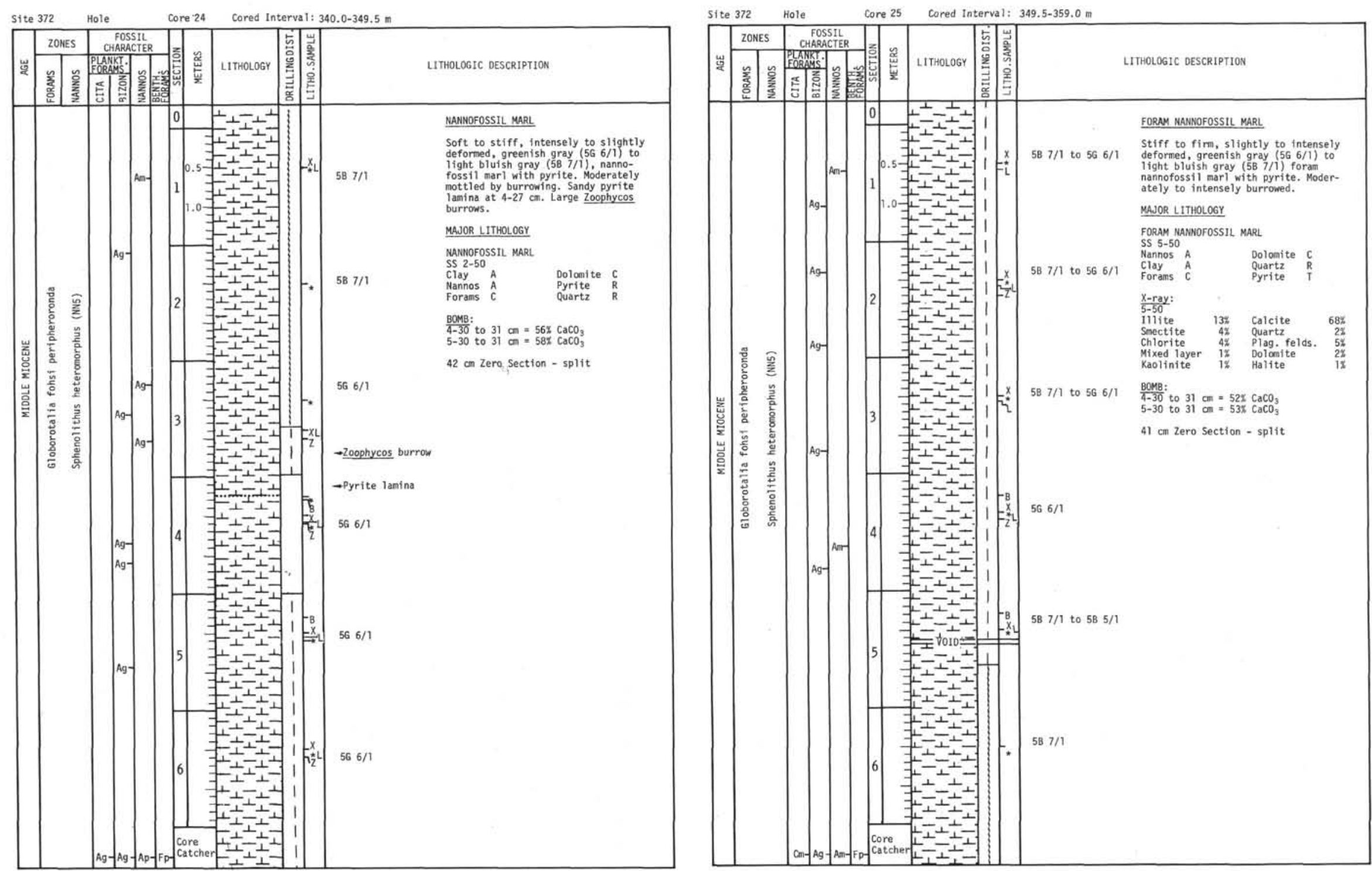


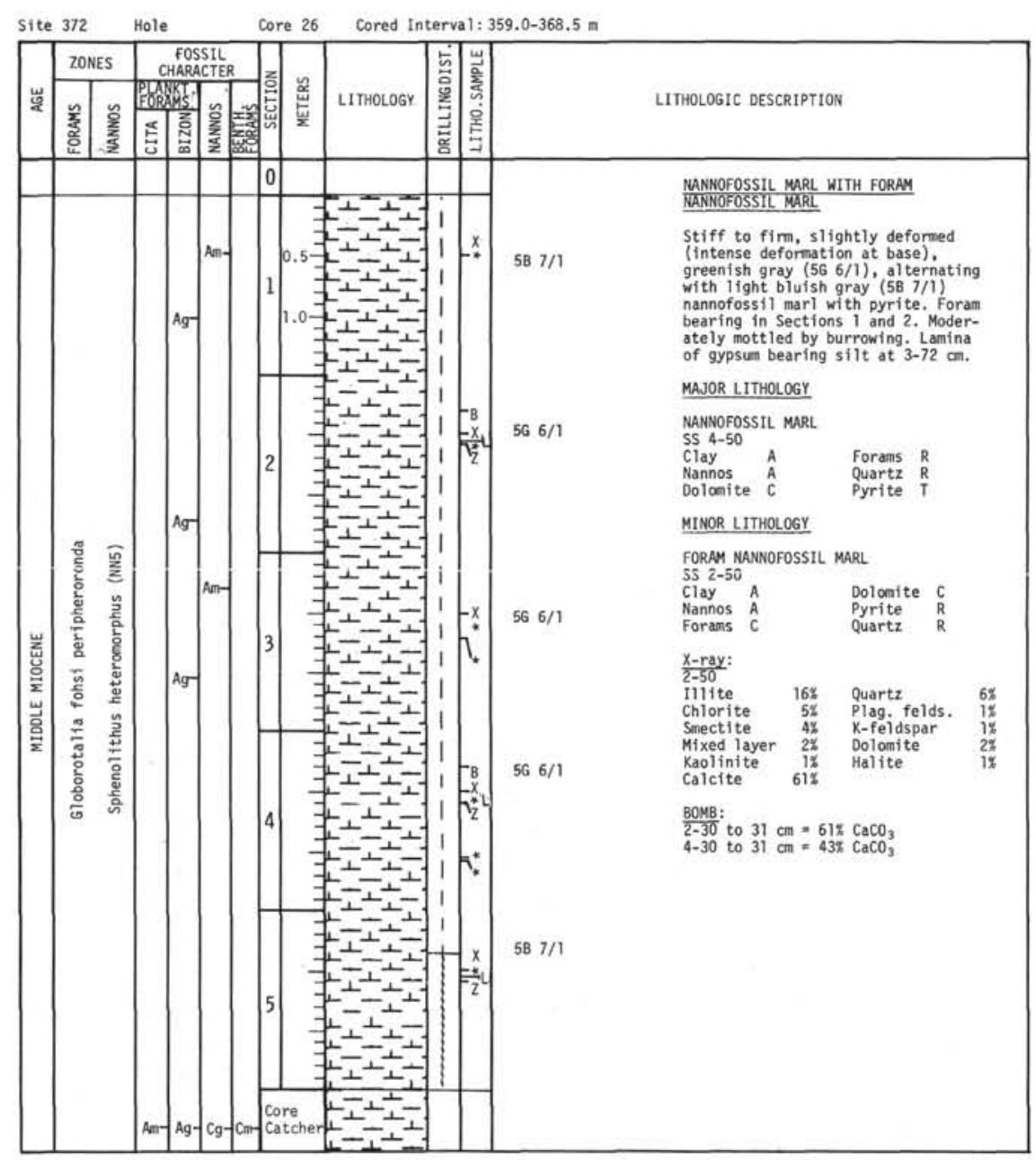

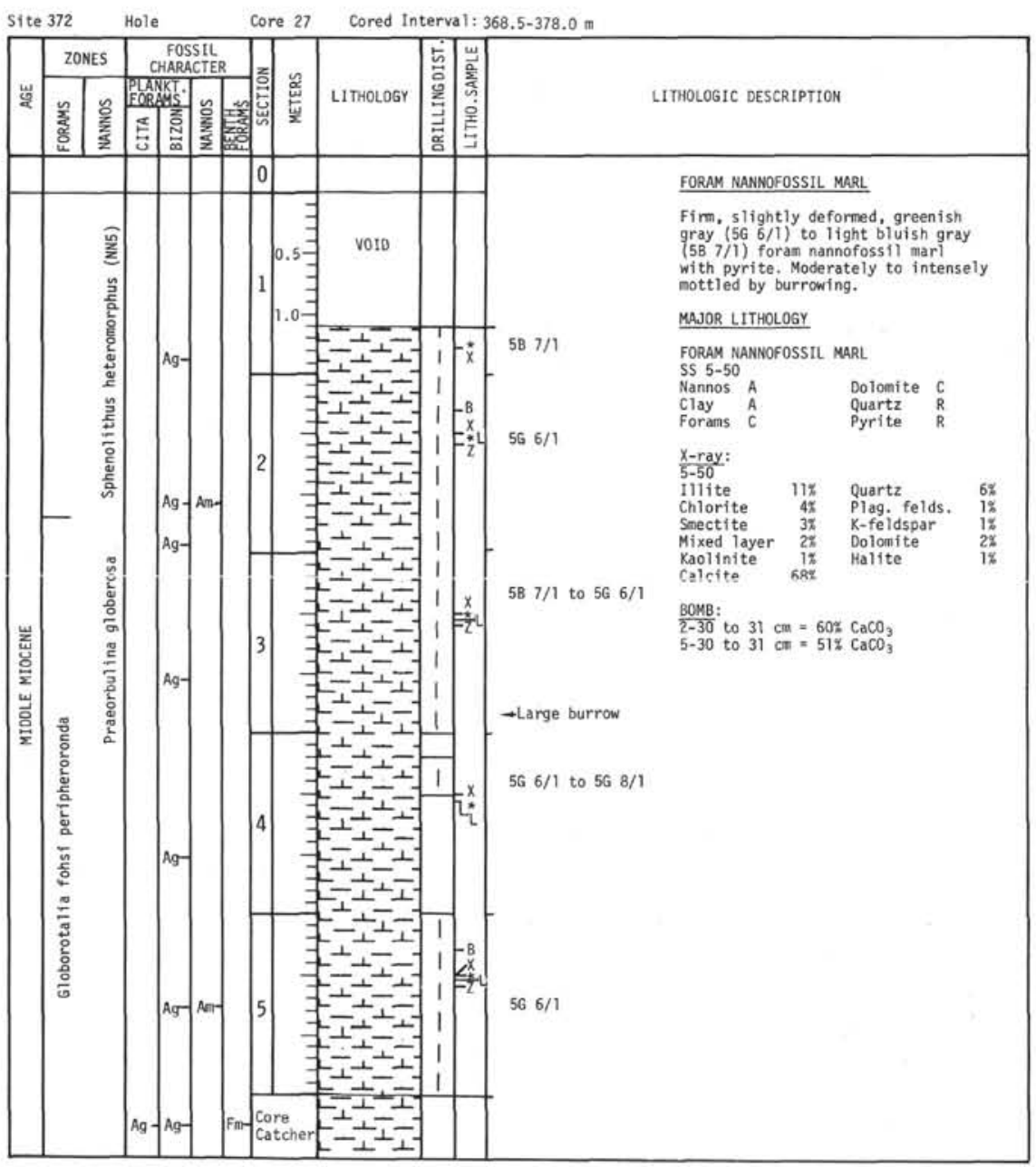




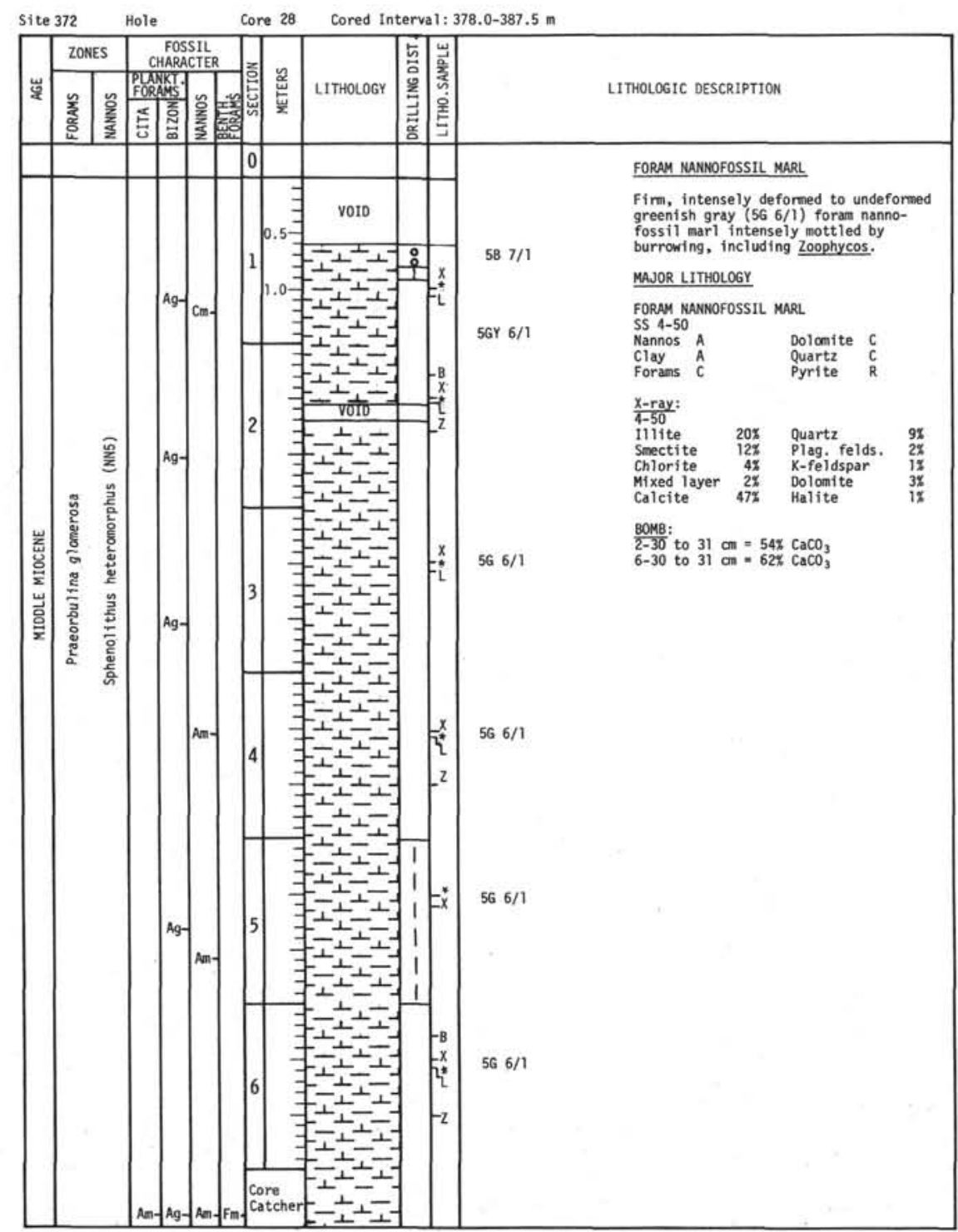

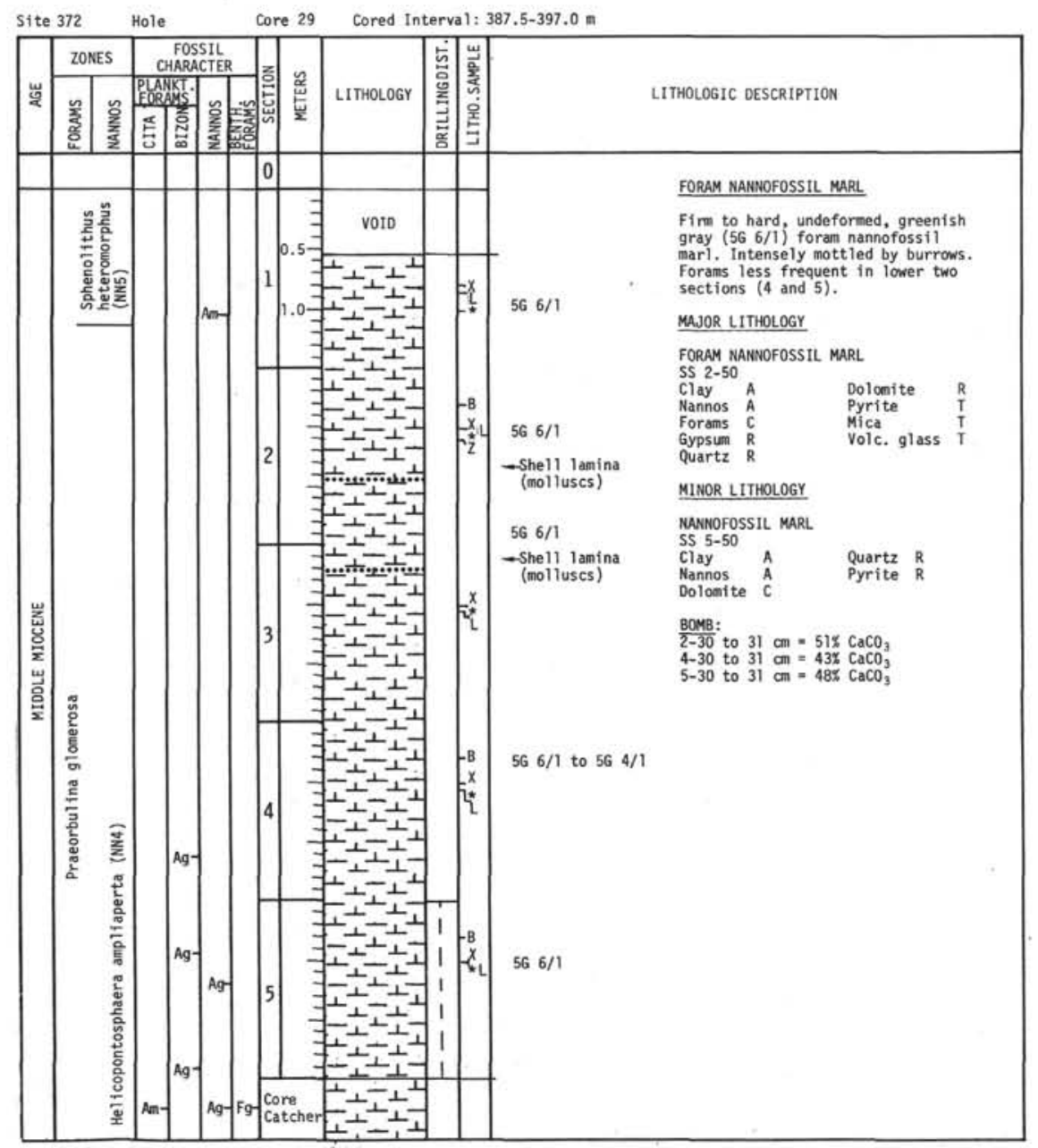



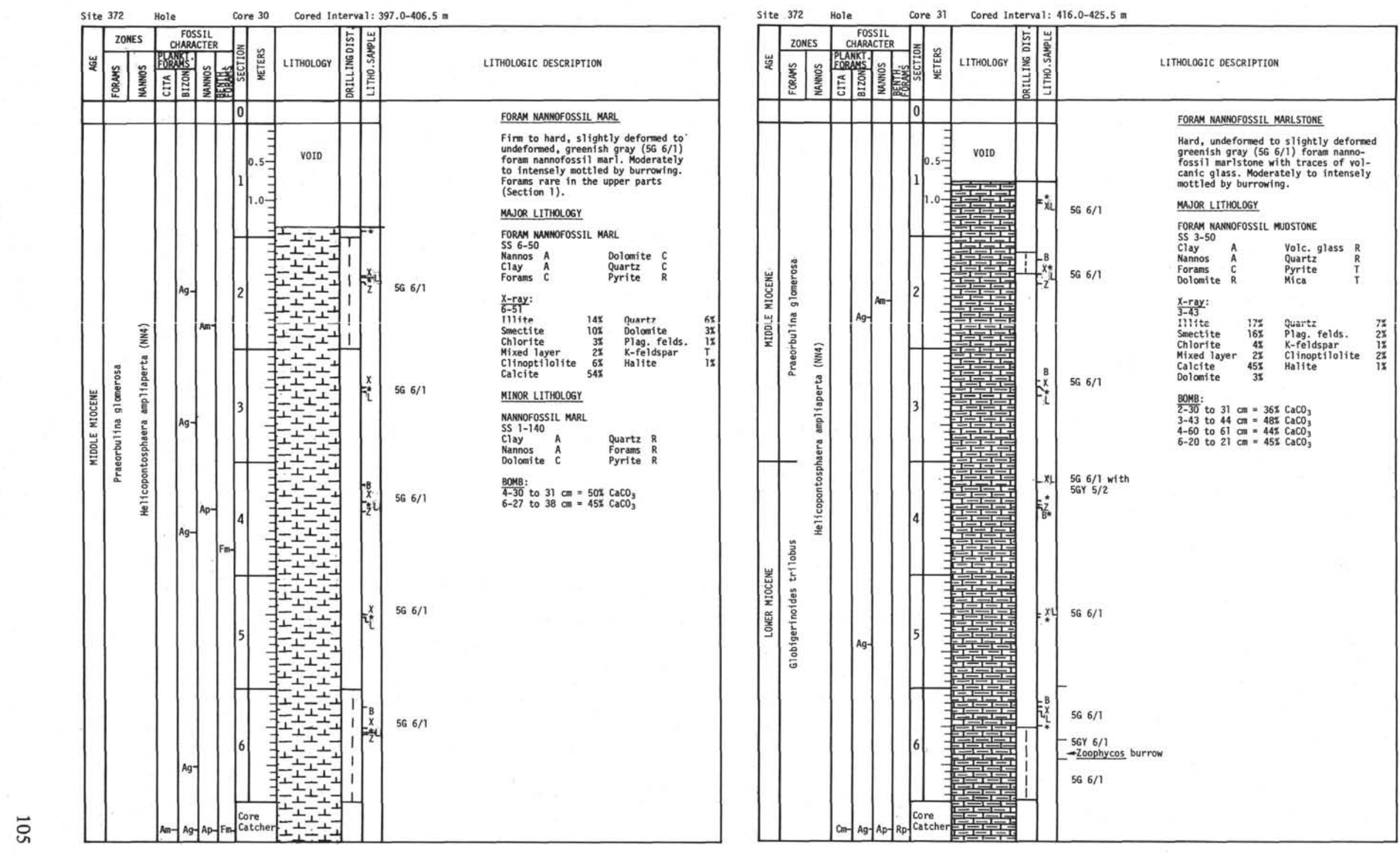


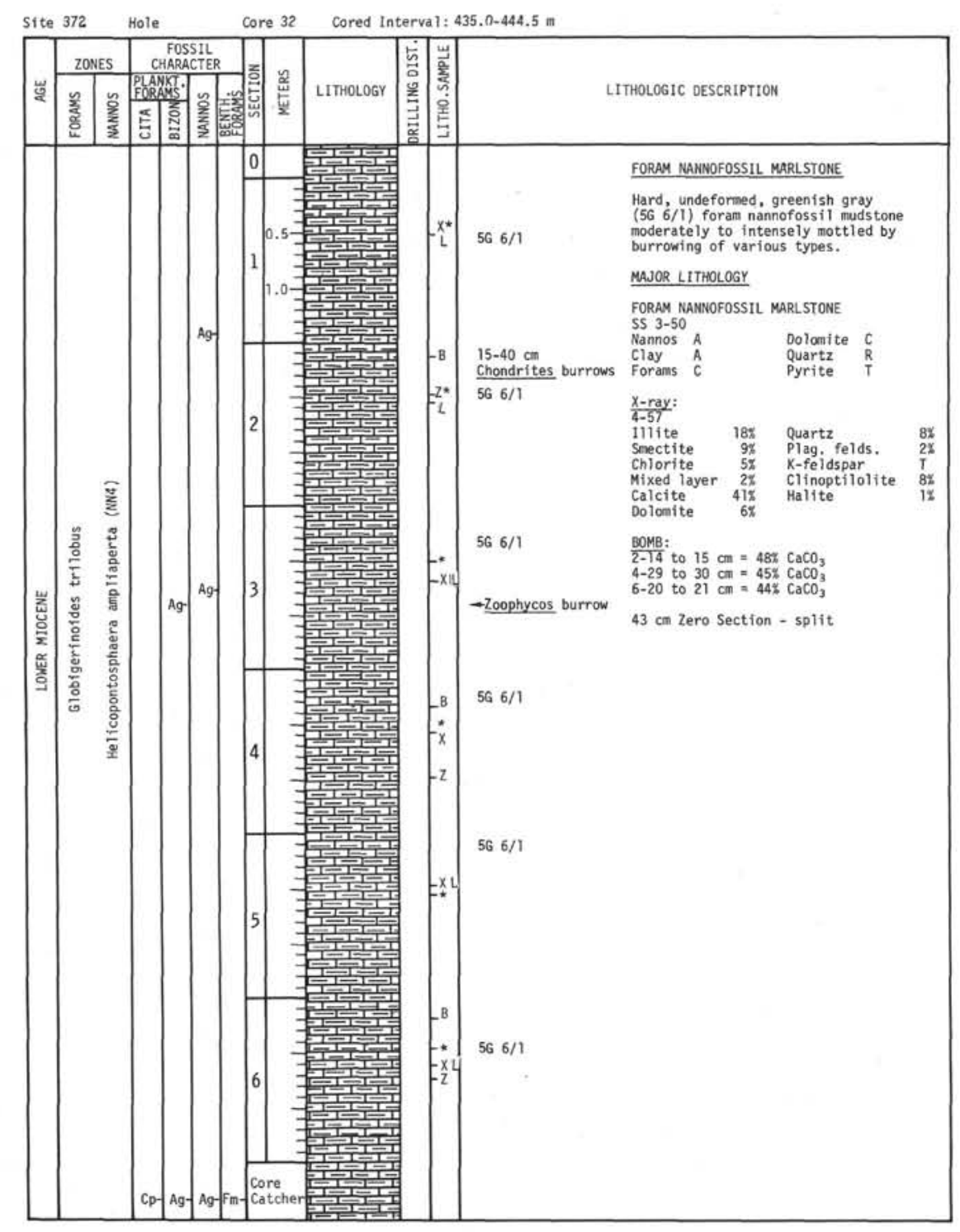

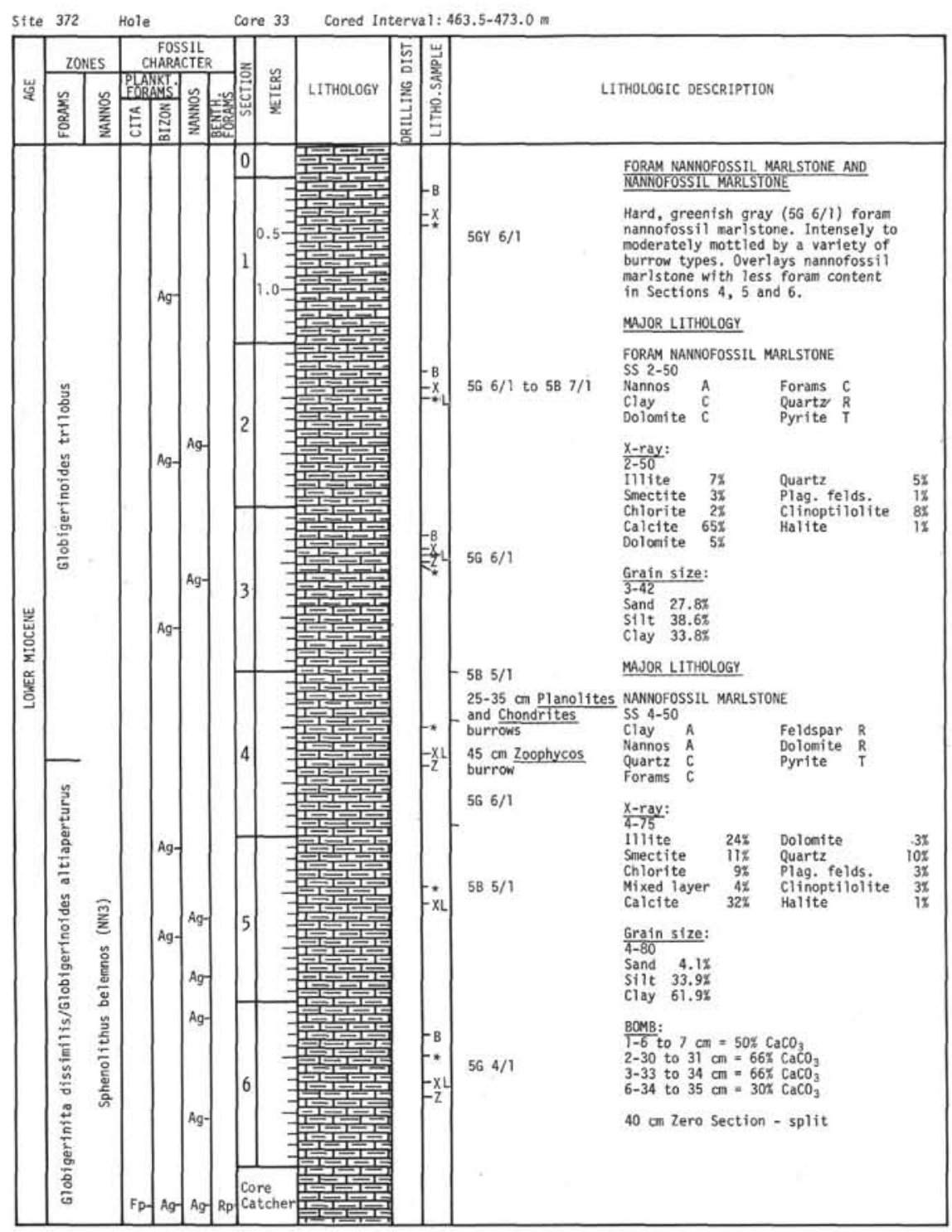




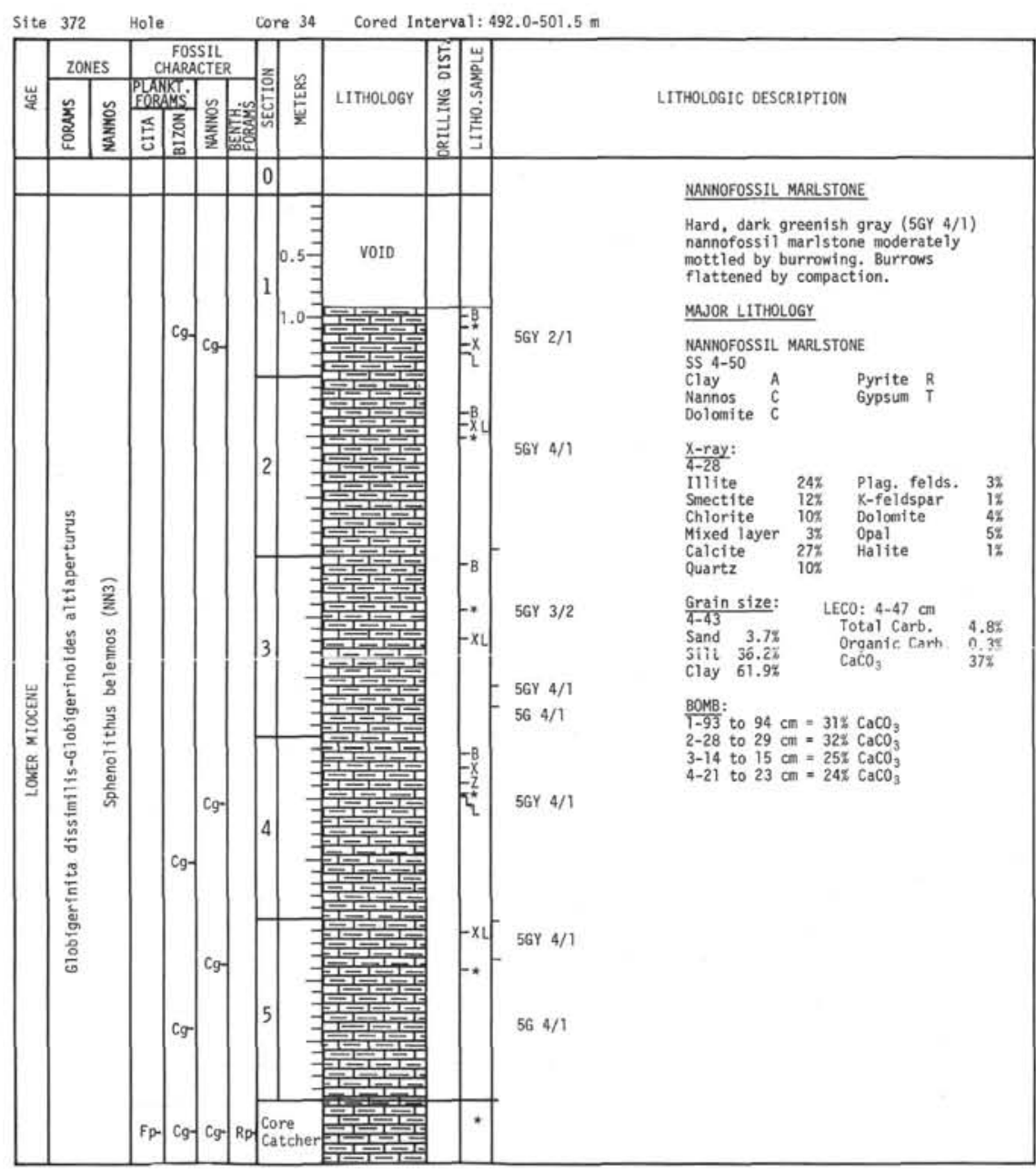

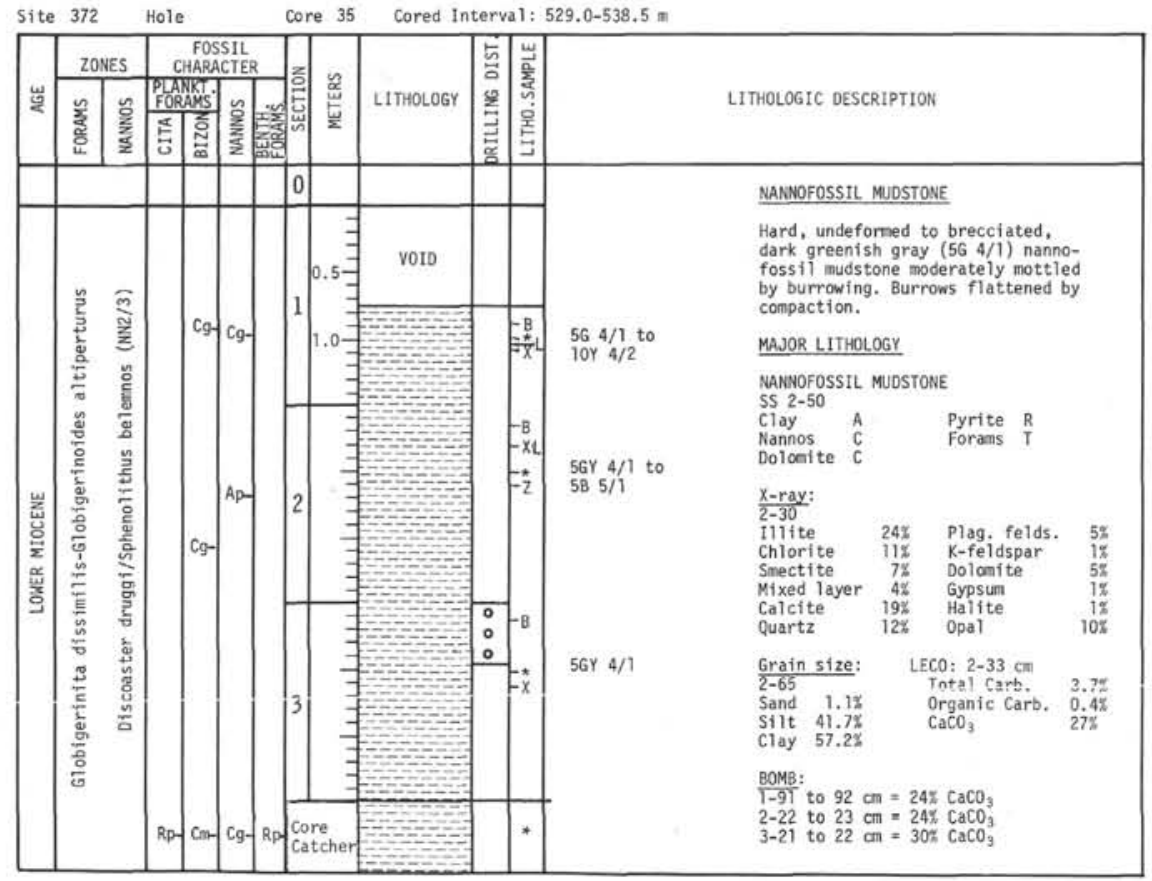




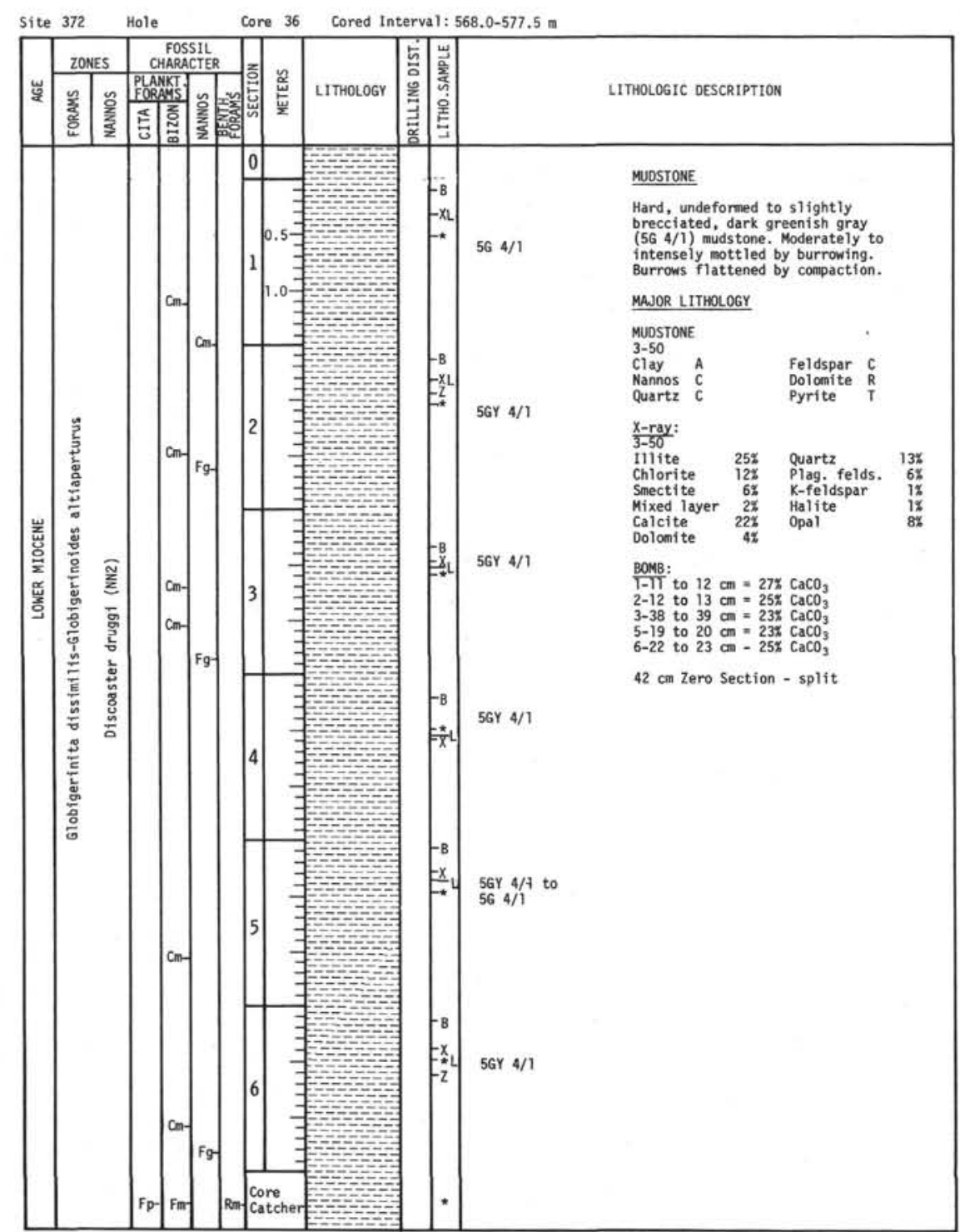

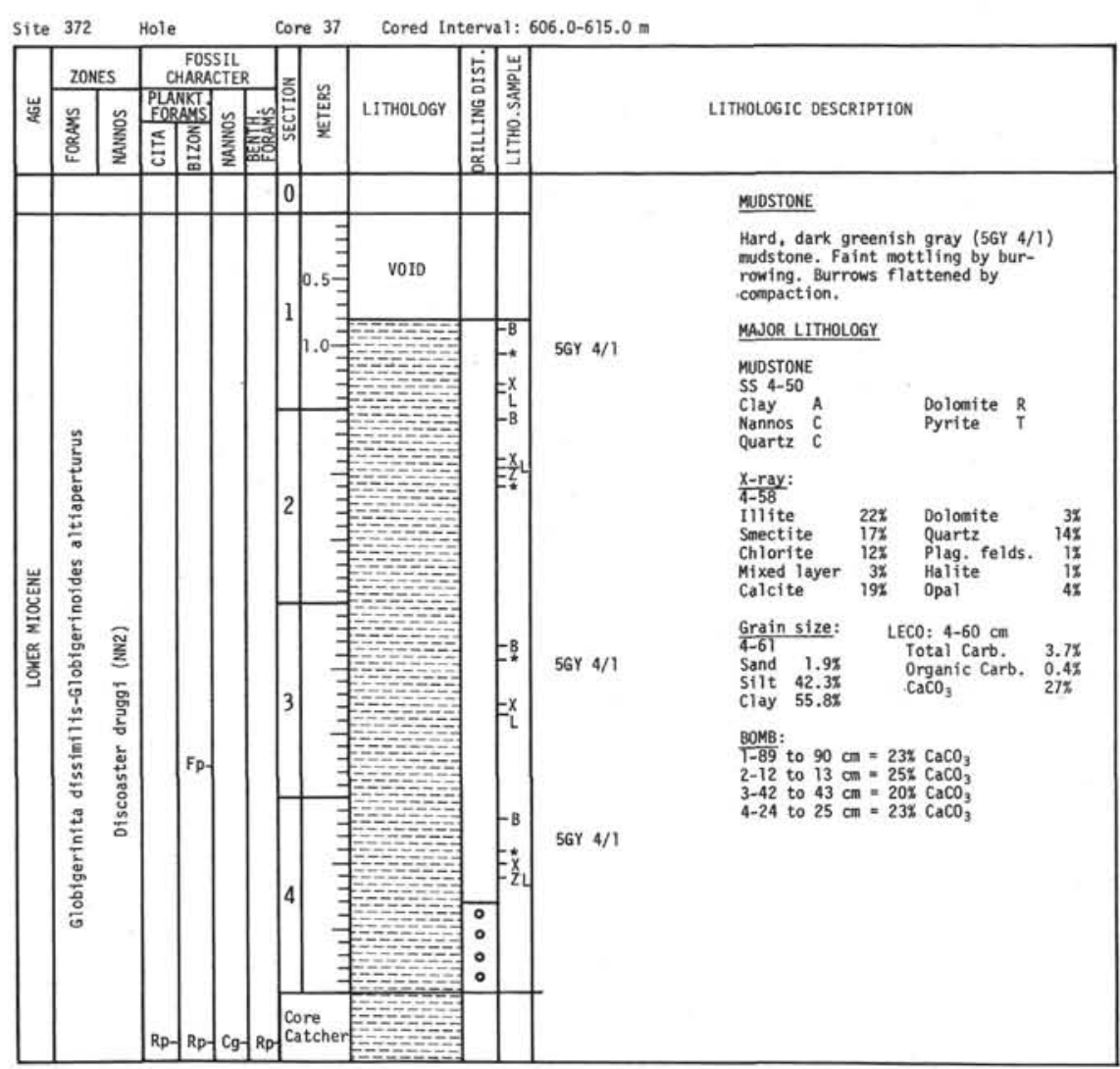



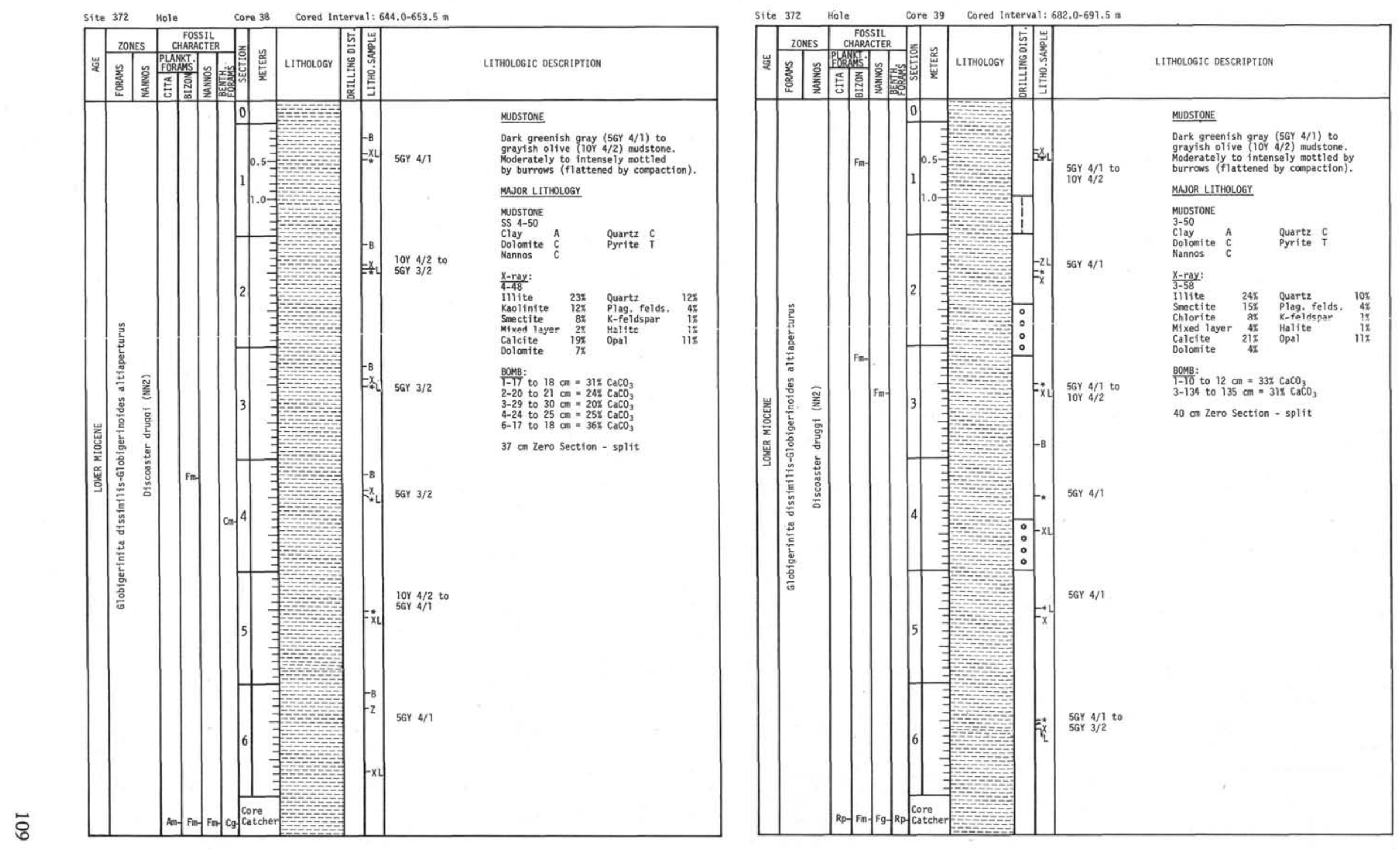

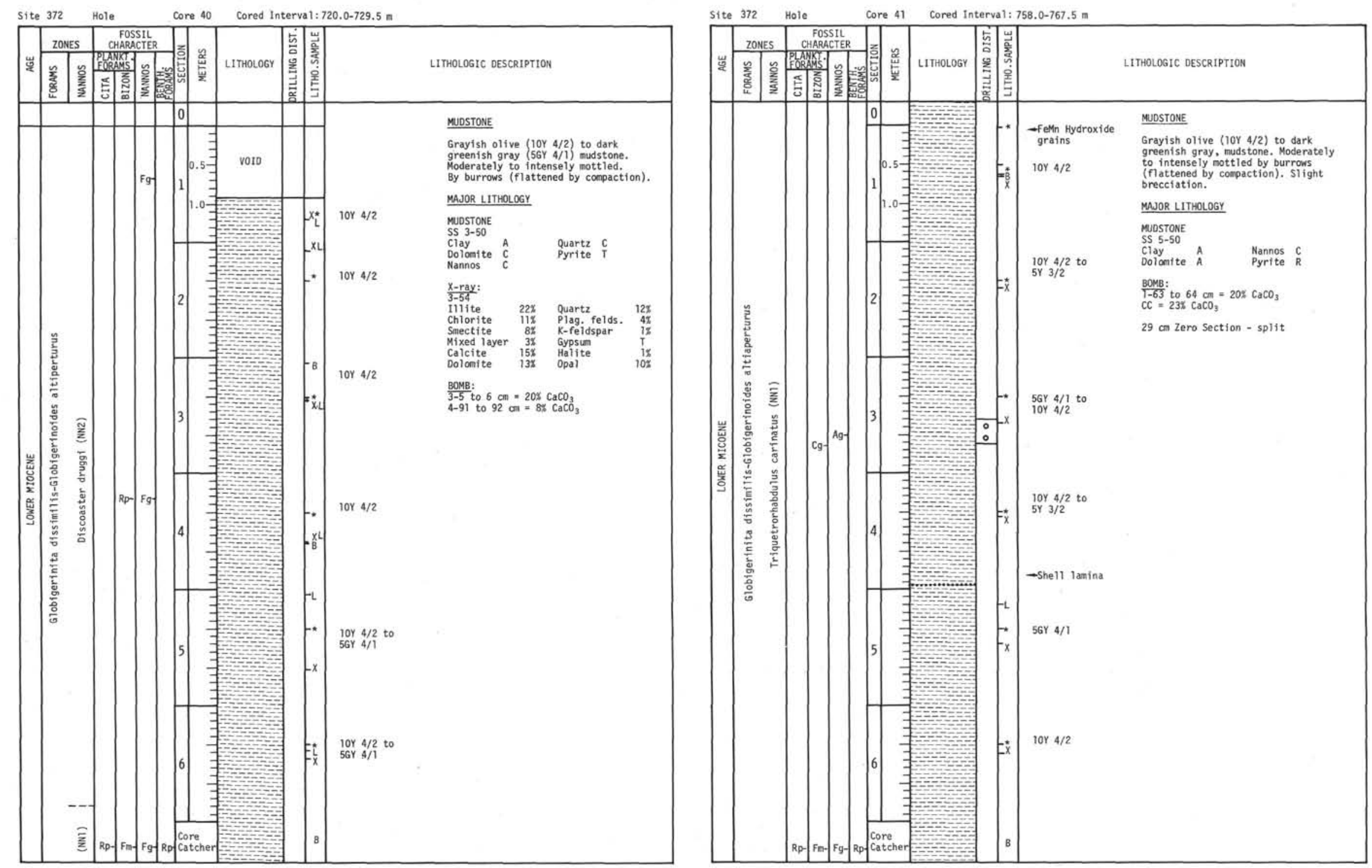

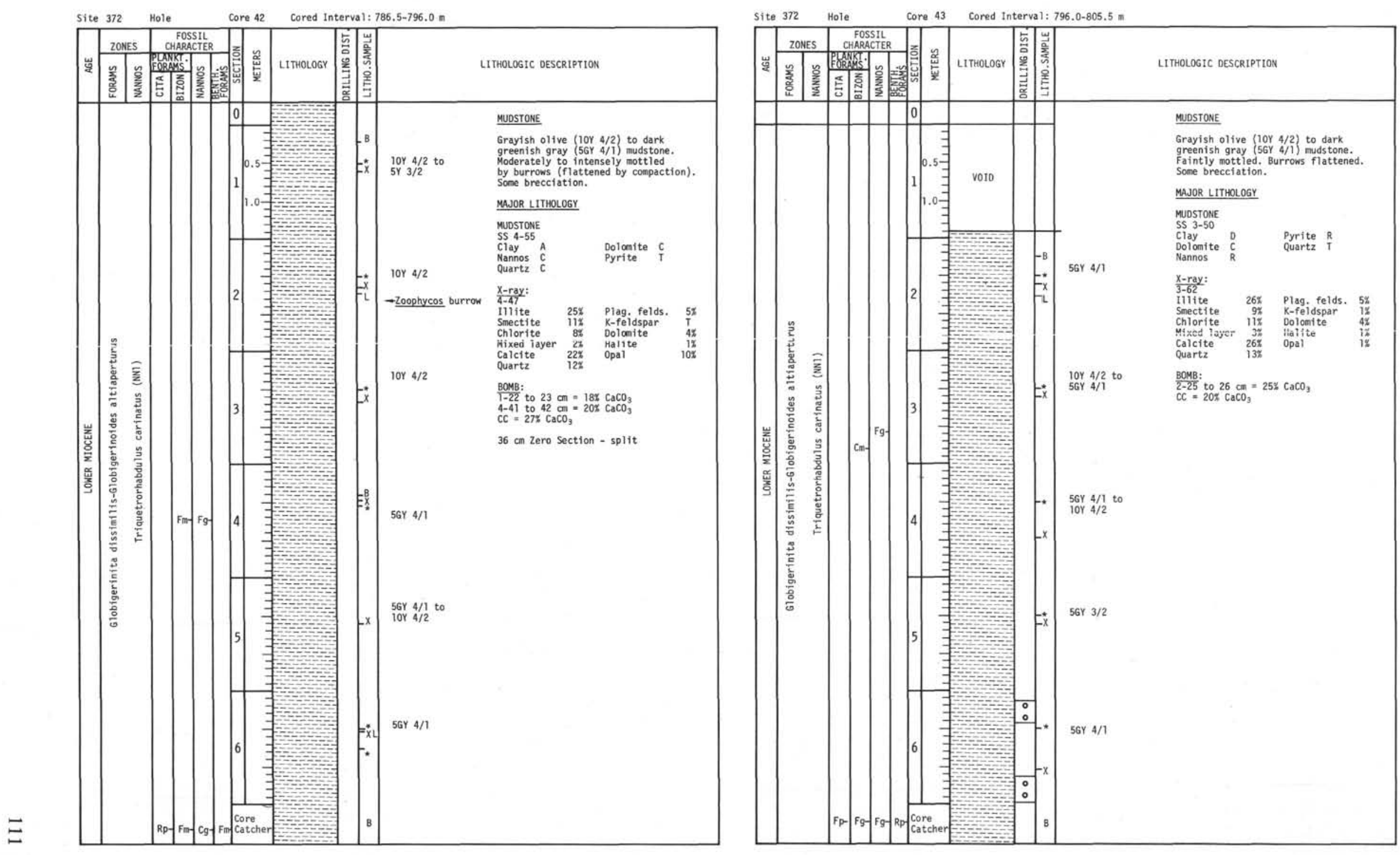

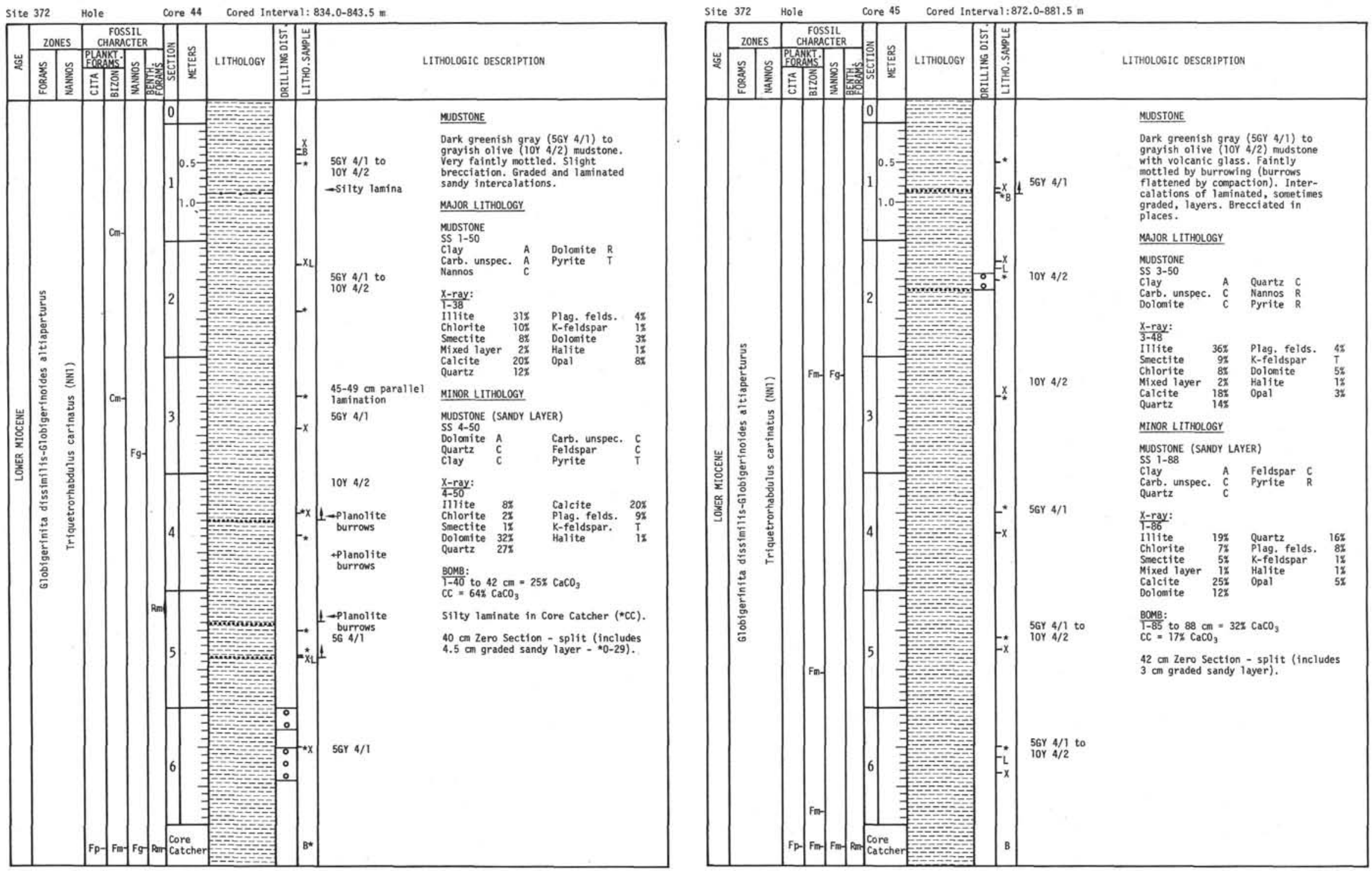


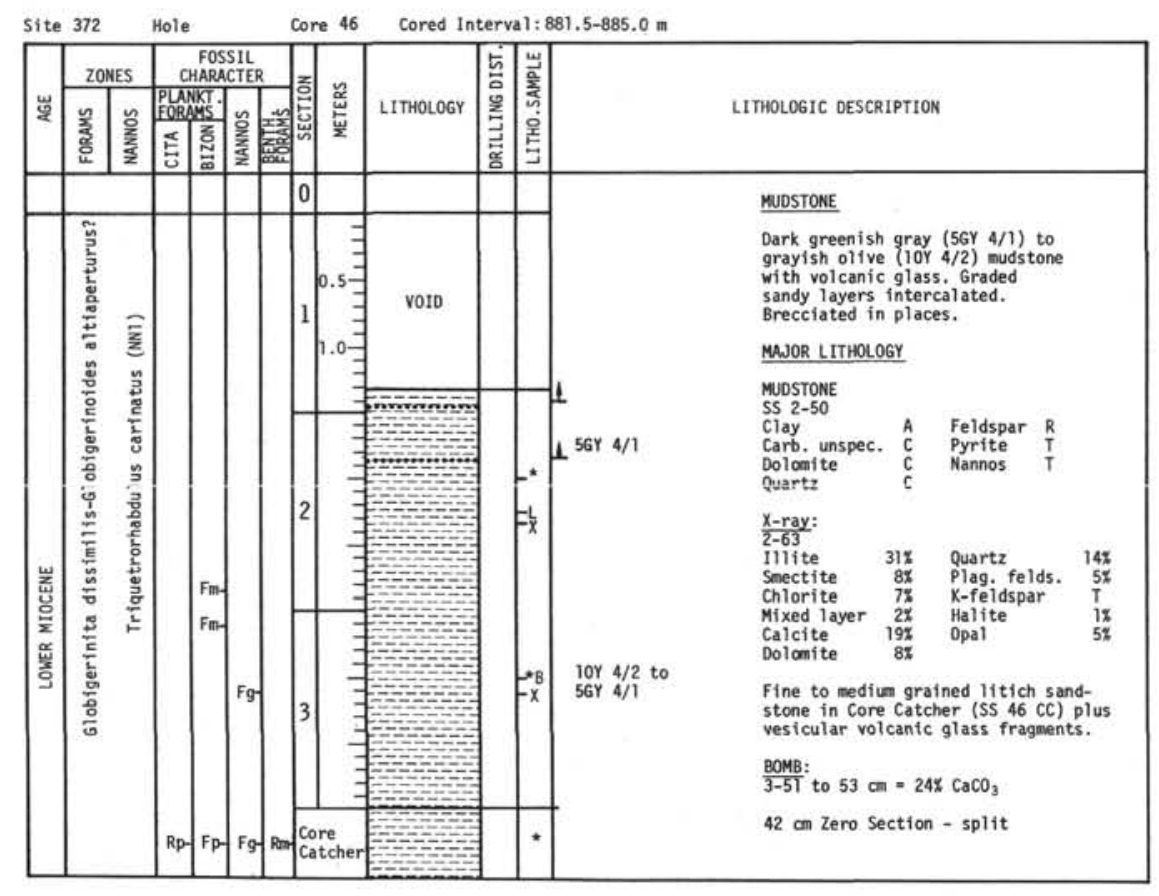


SITE 372: MENORCA RISE

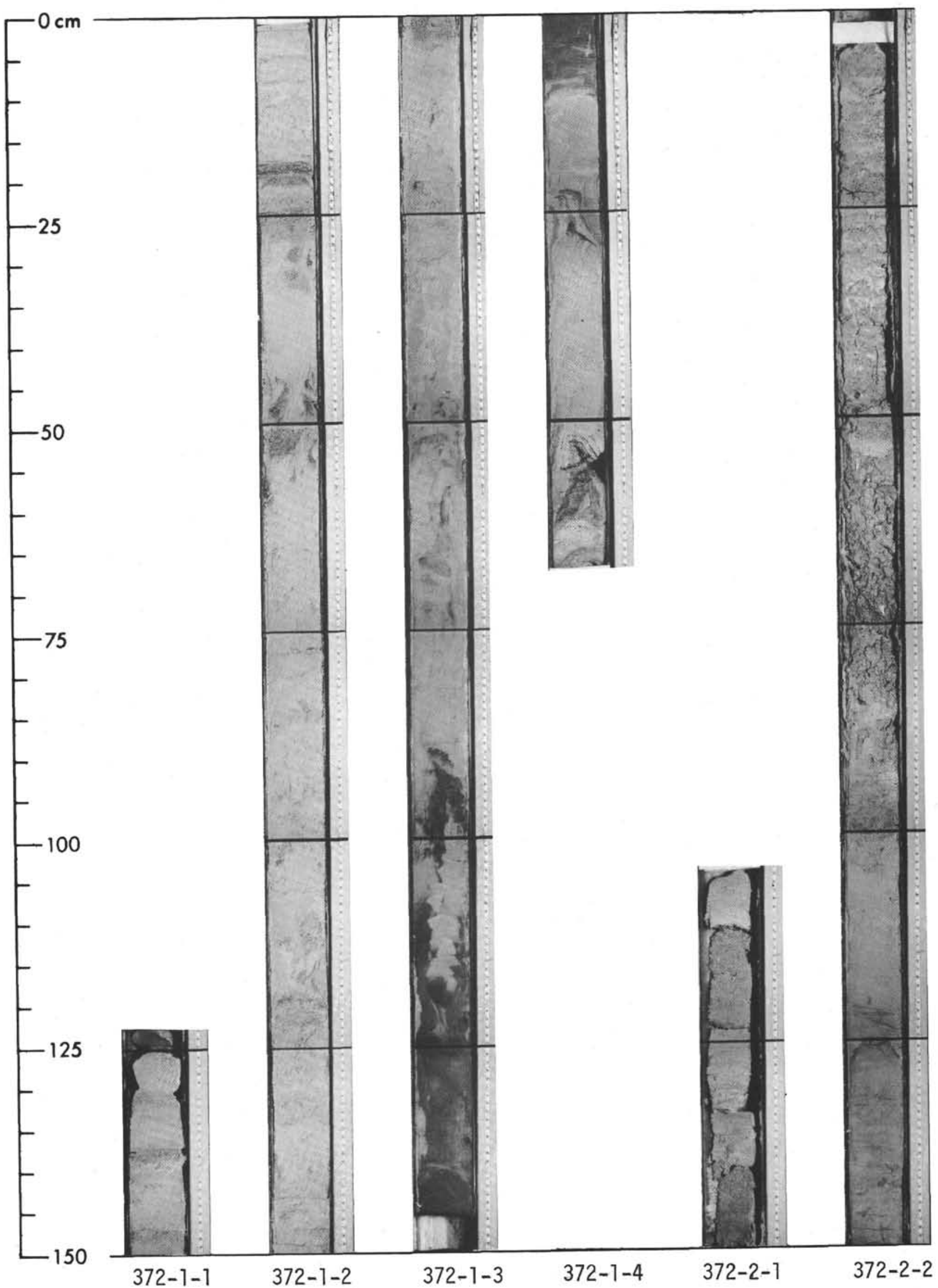


SITE 372: MENORCA RISE

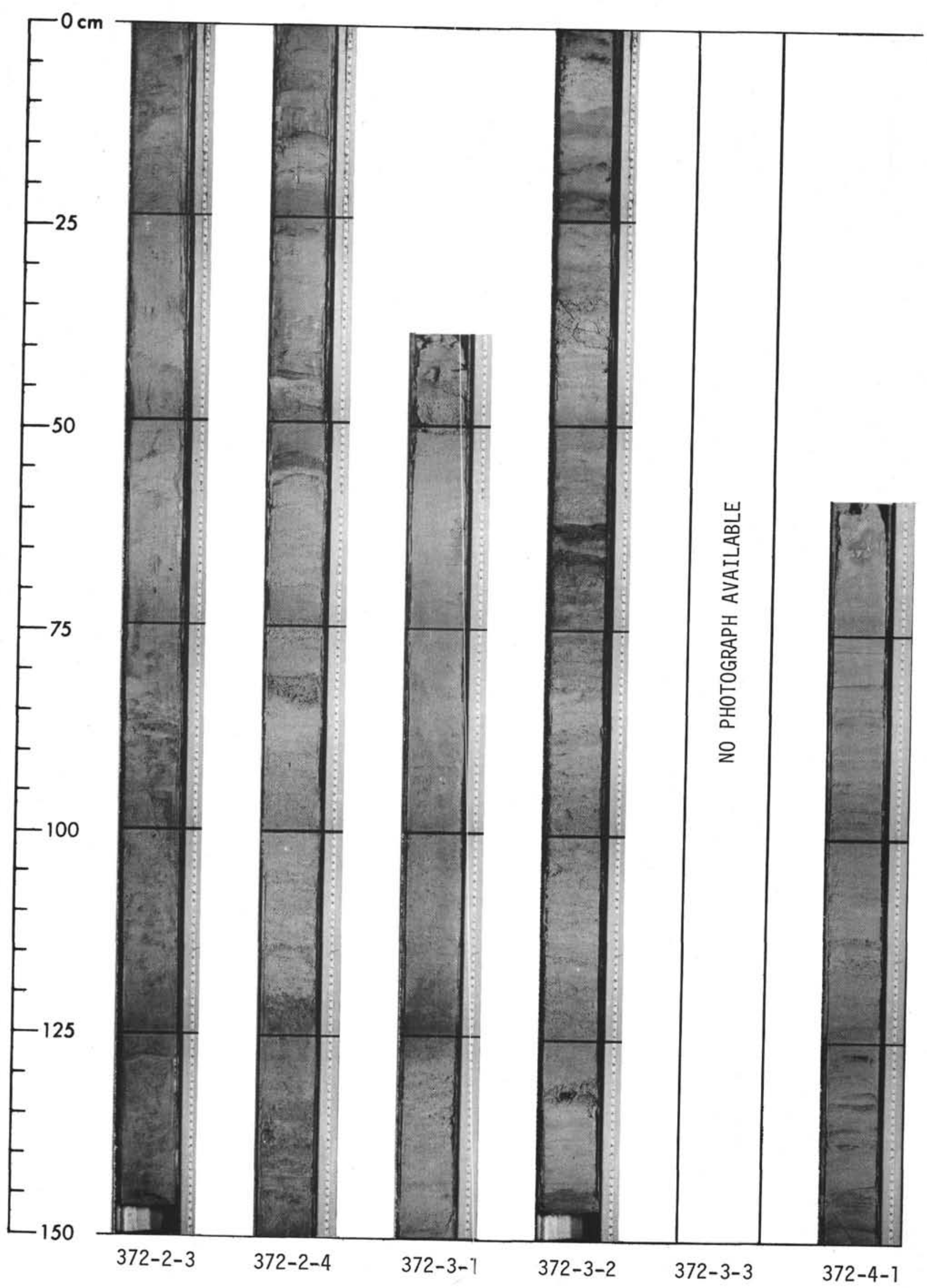


SITE 372: MENORCA RISE

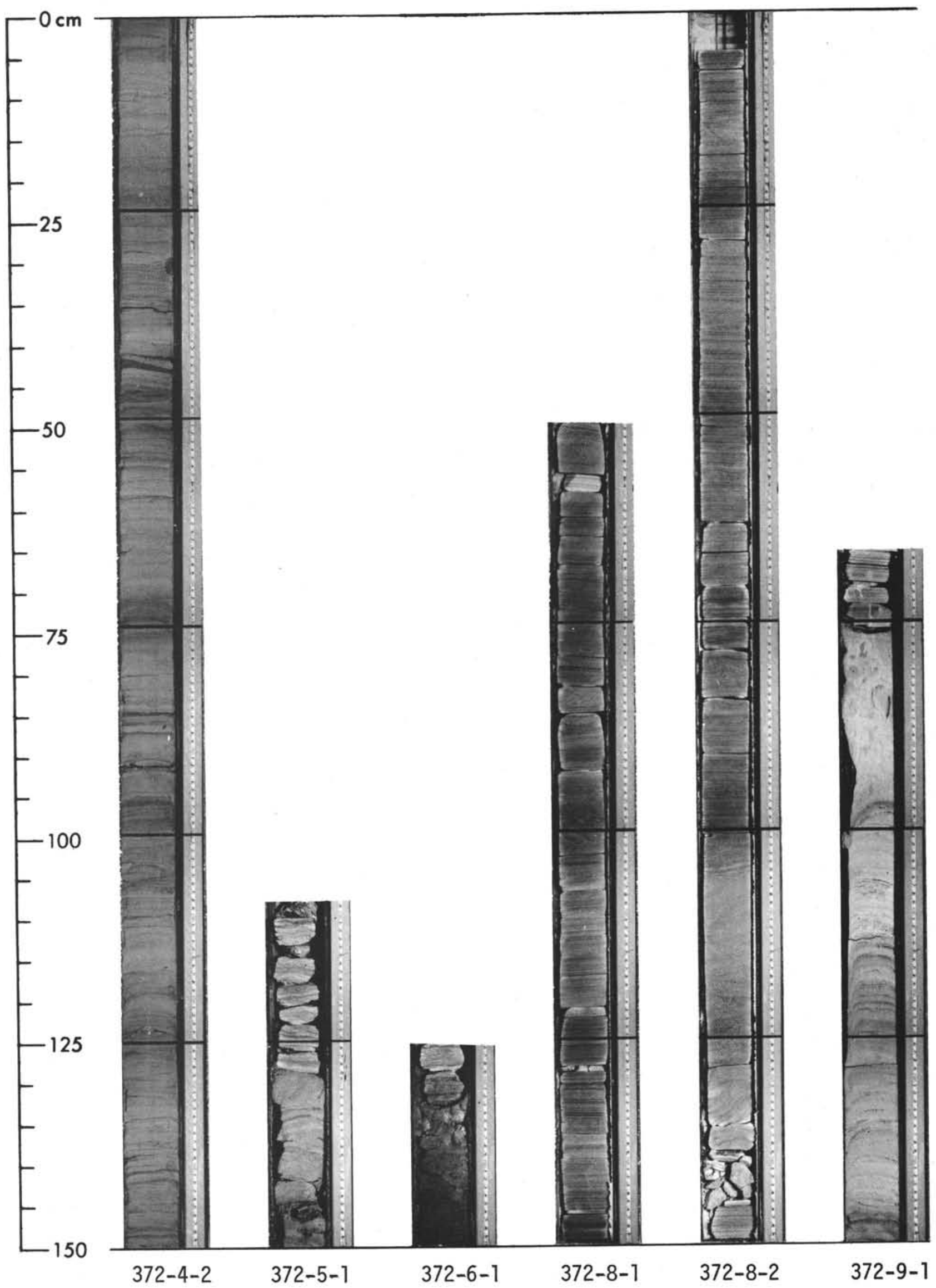




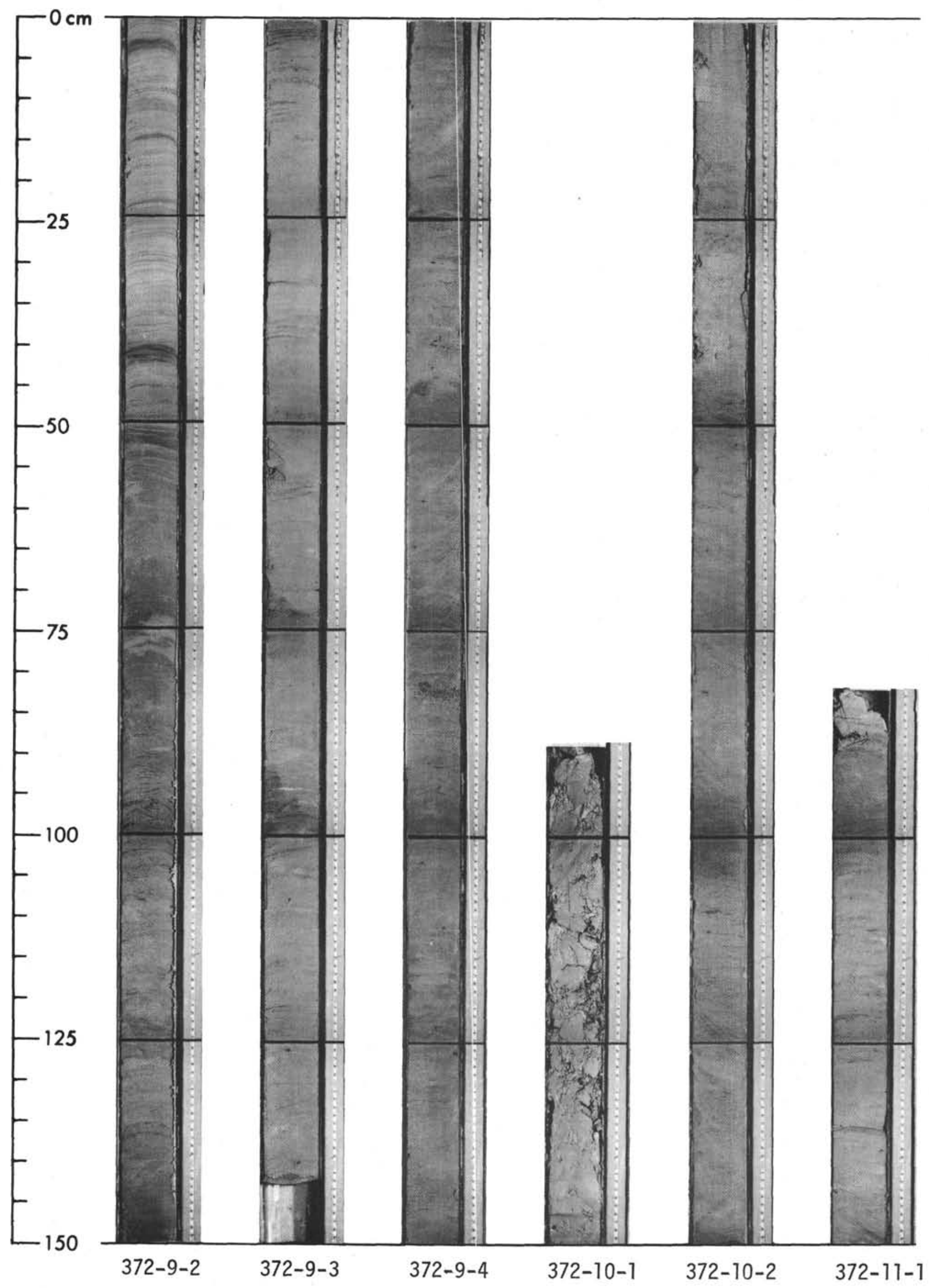




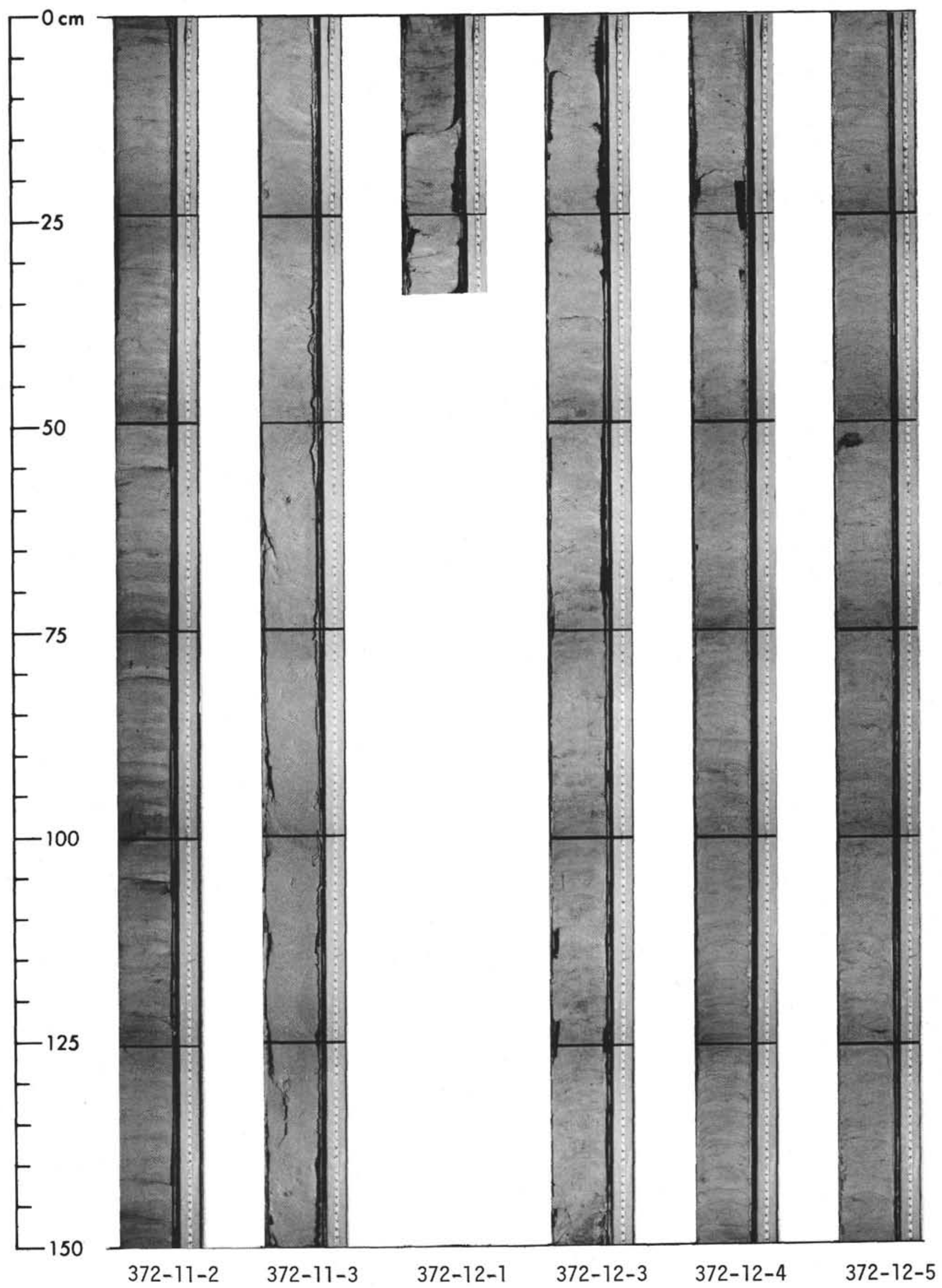




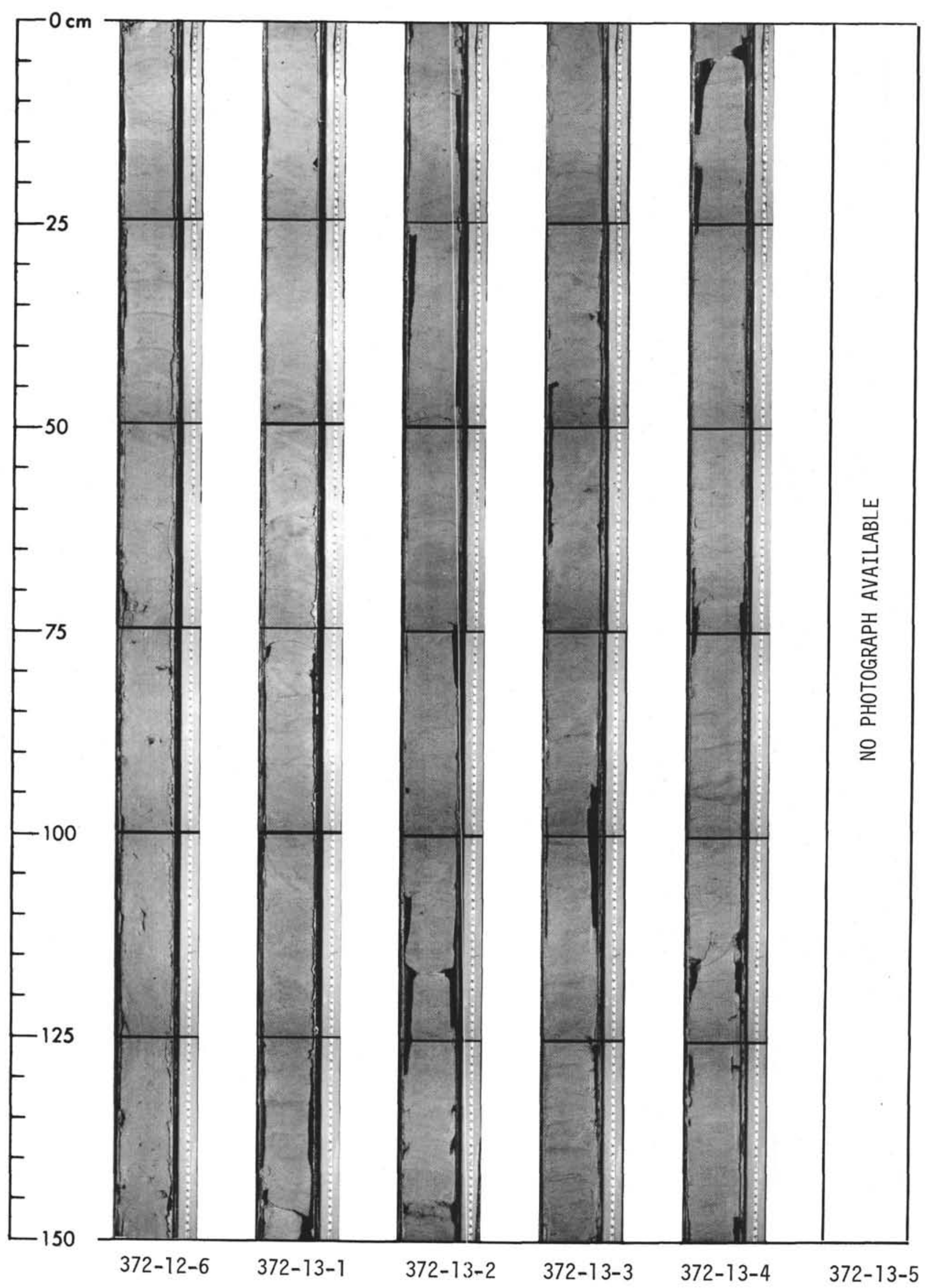




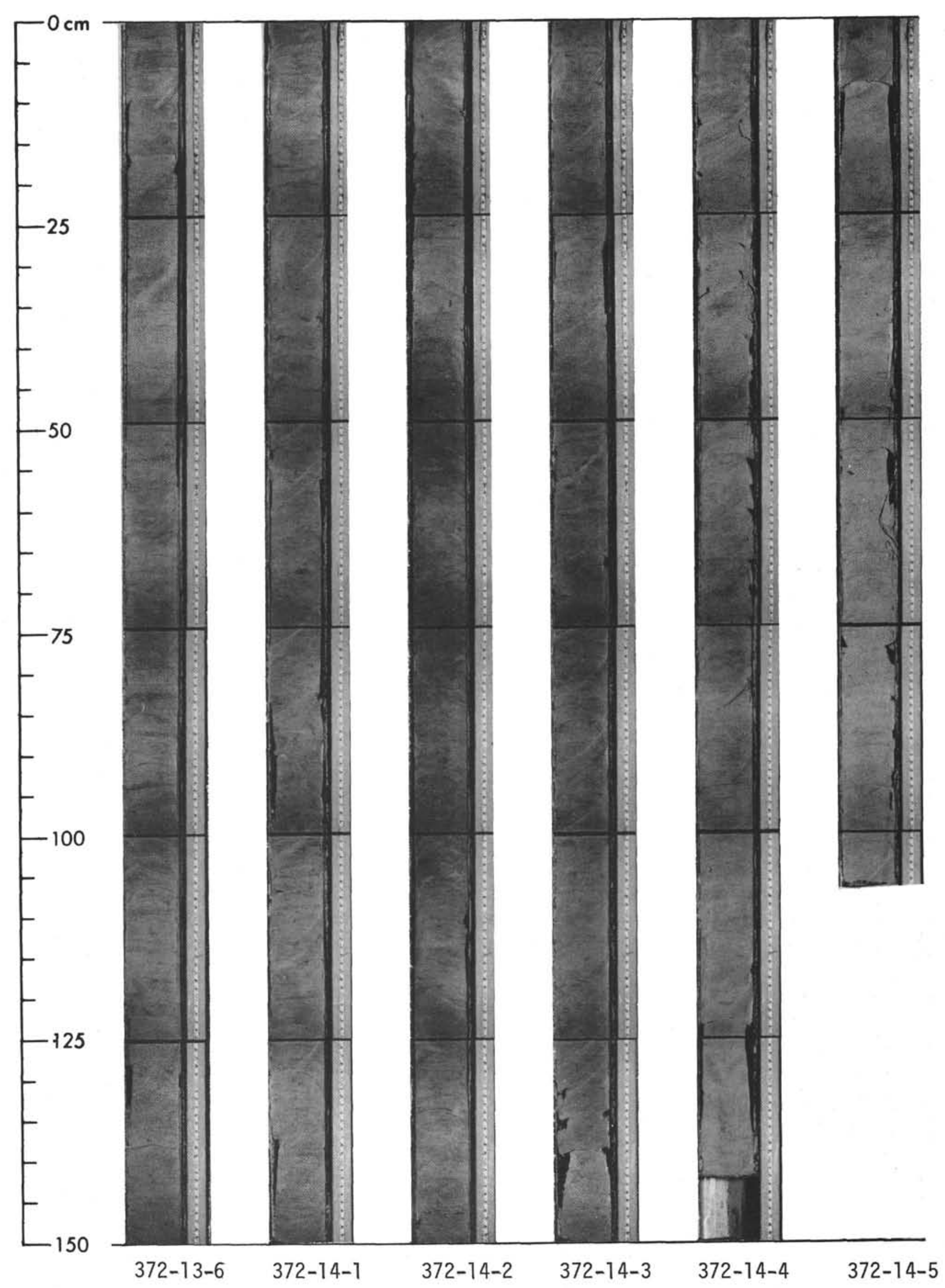




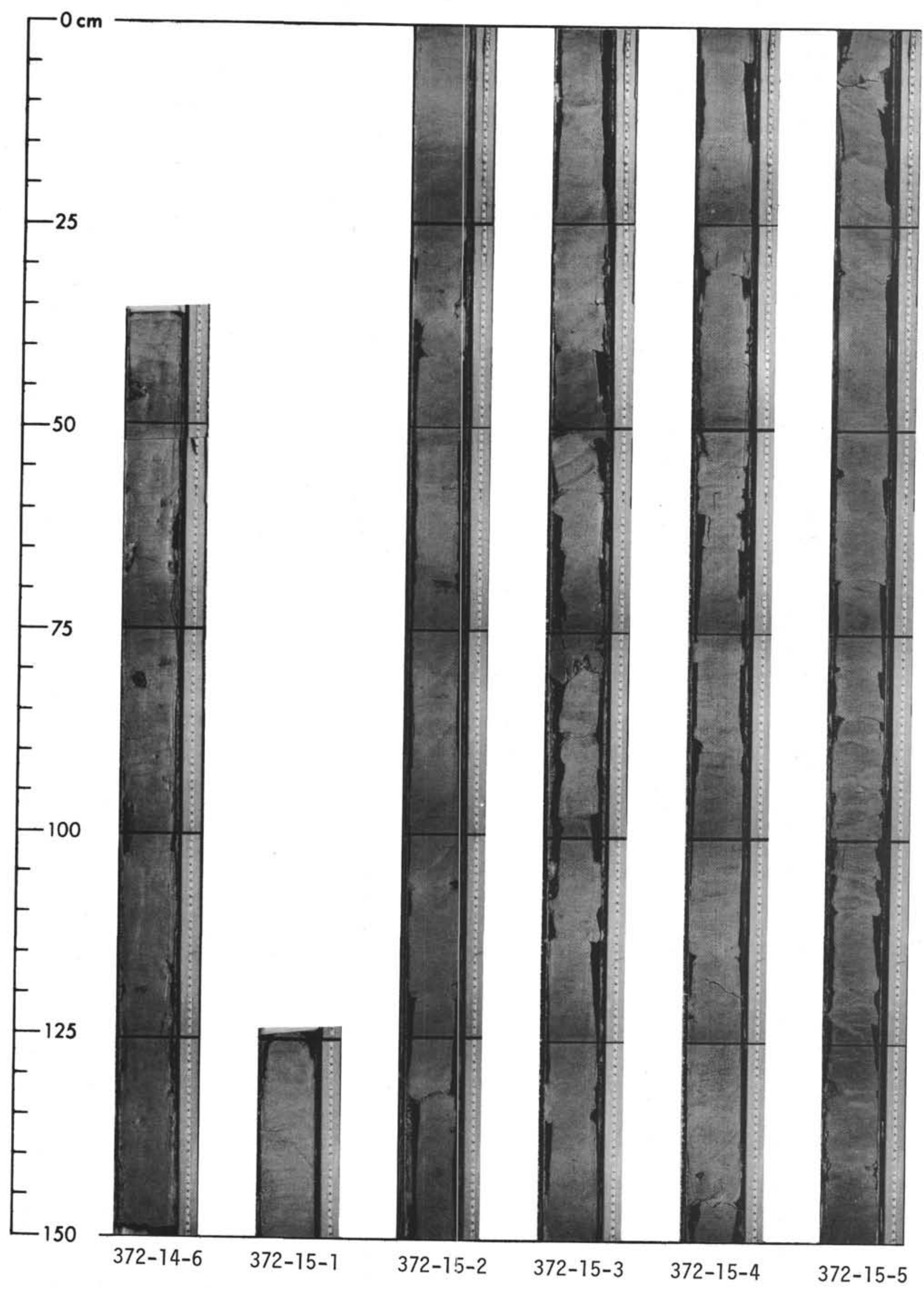




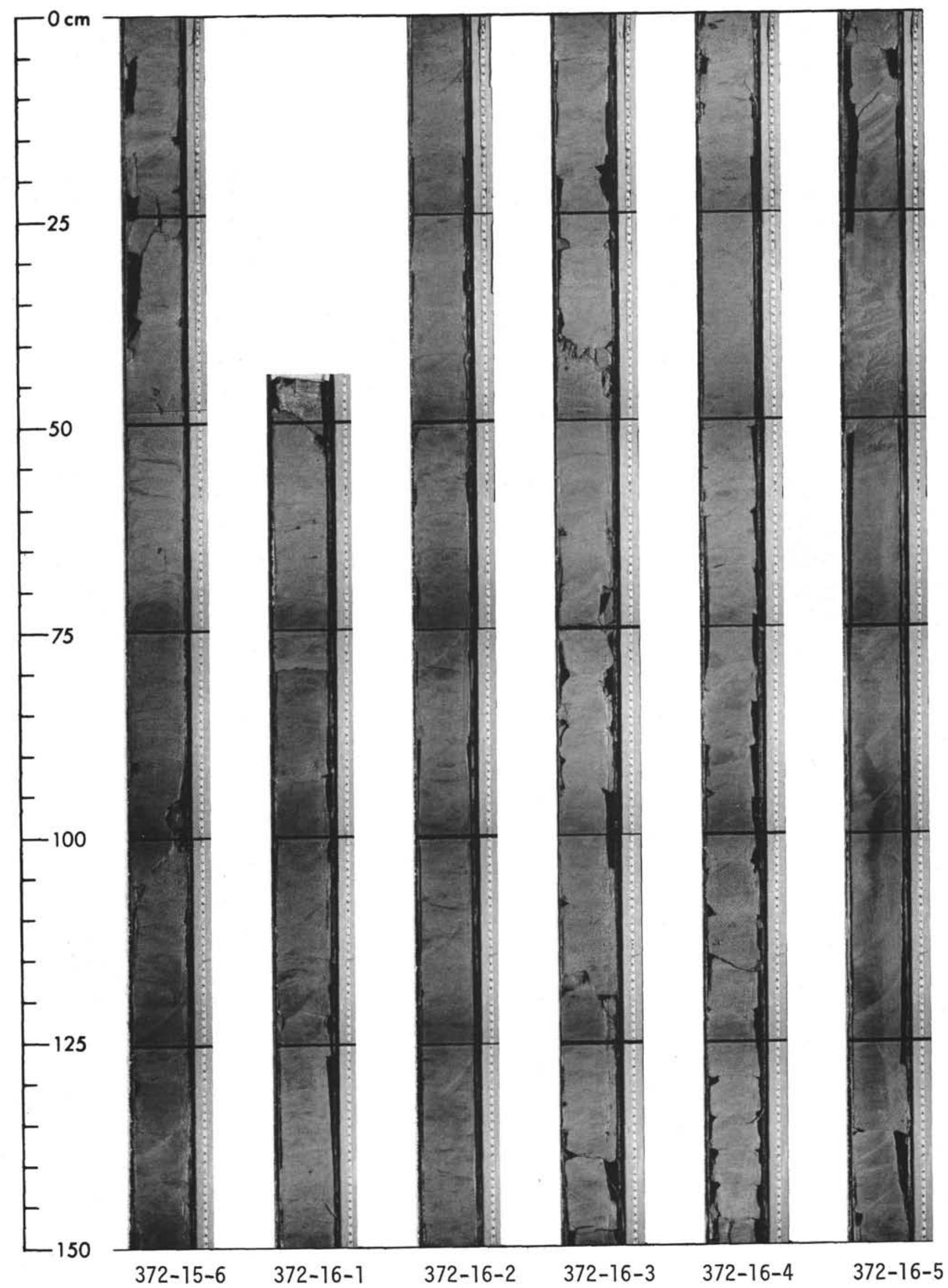




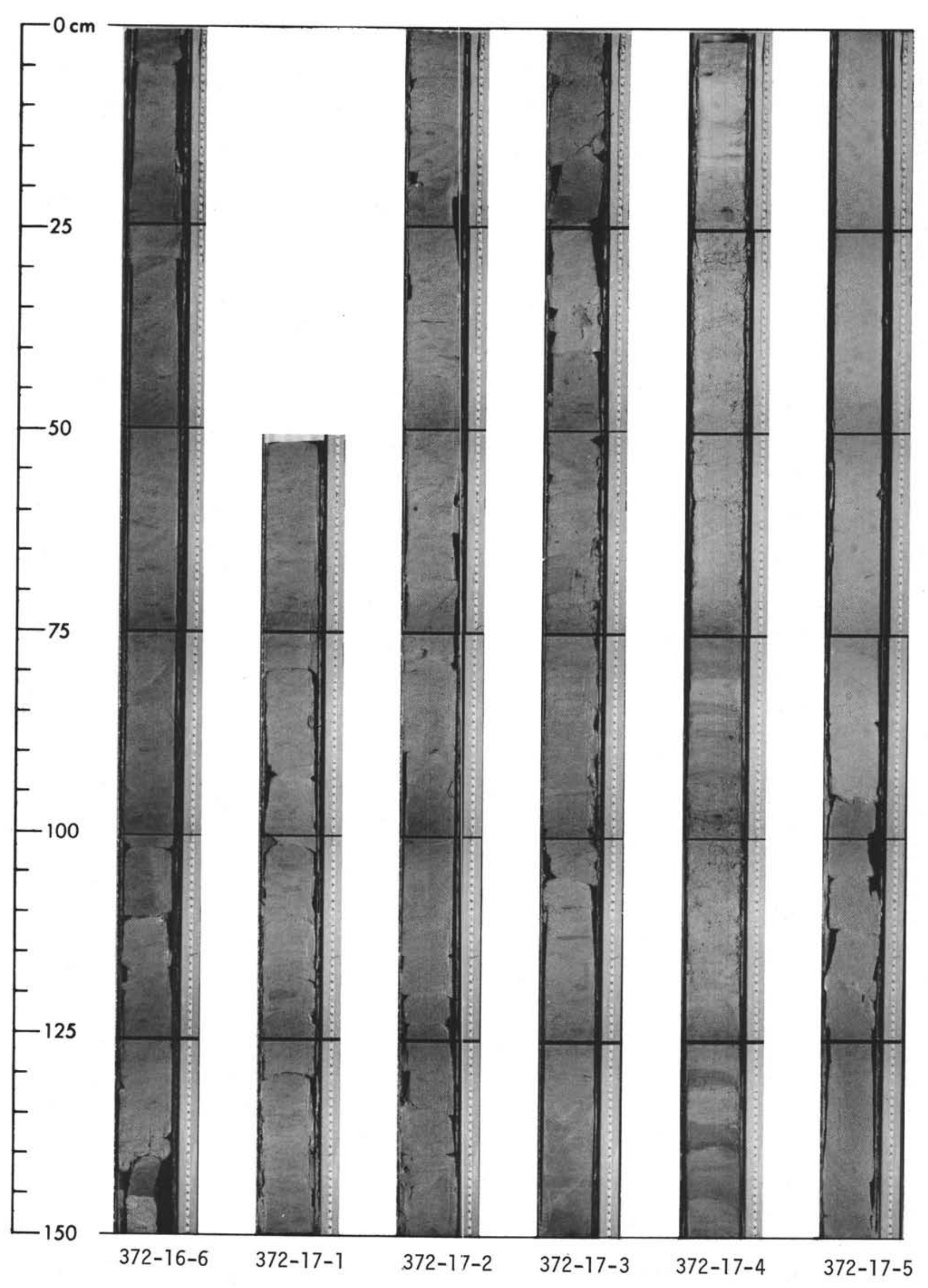




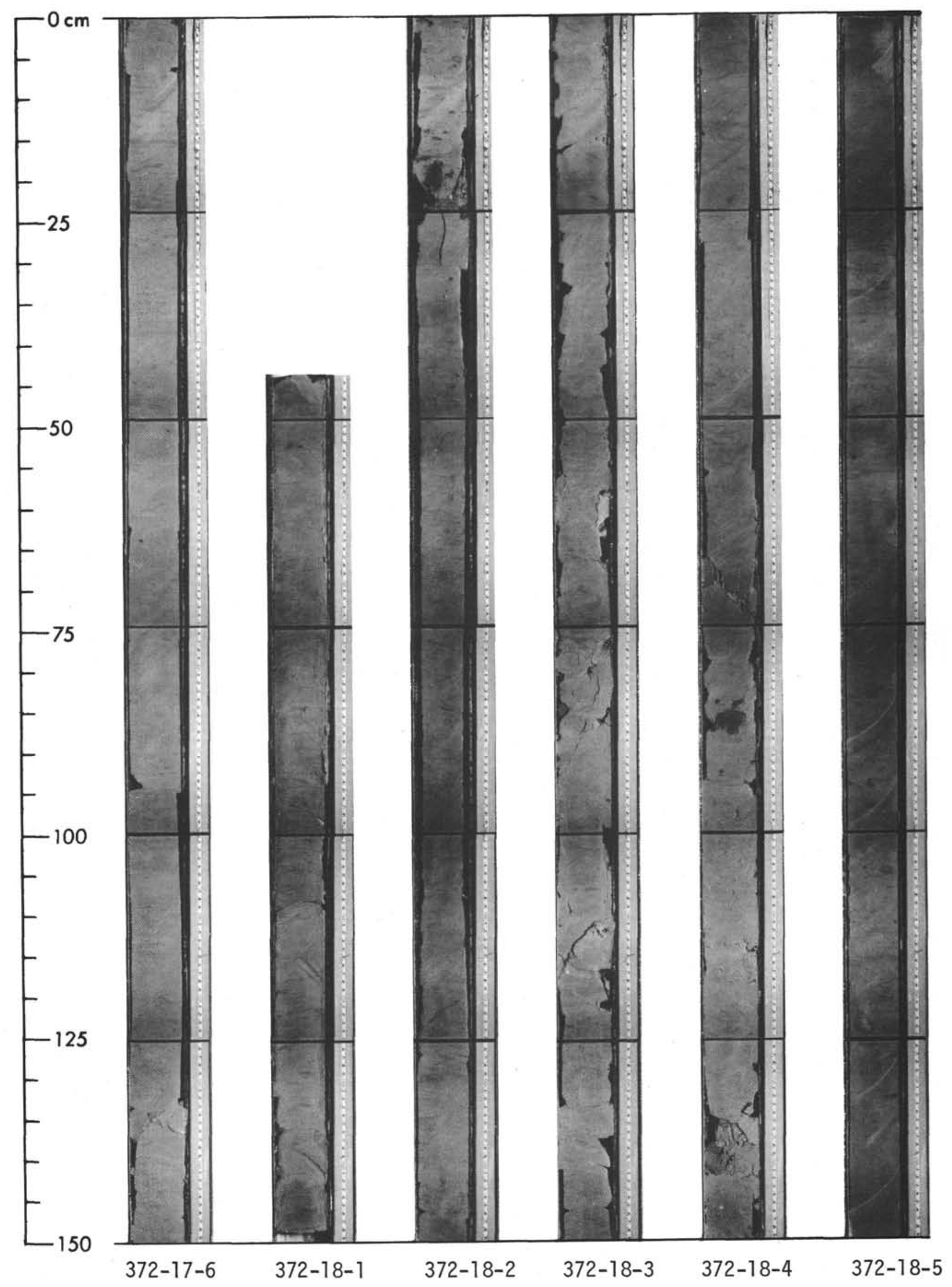




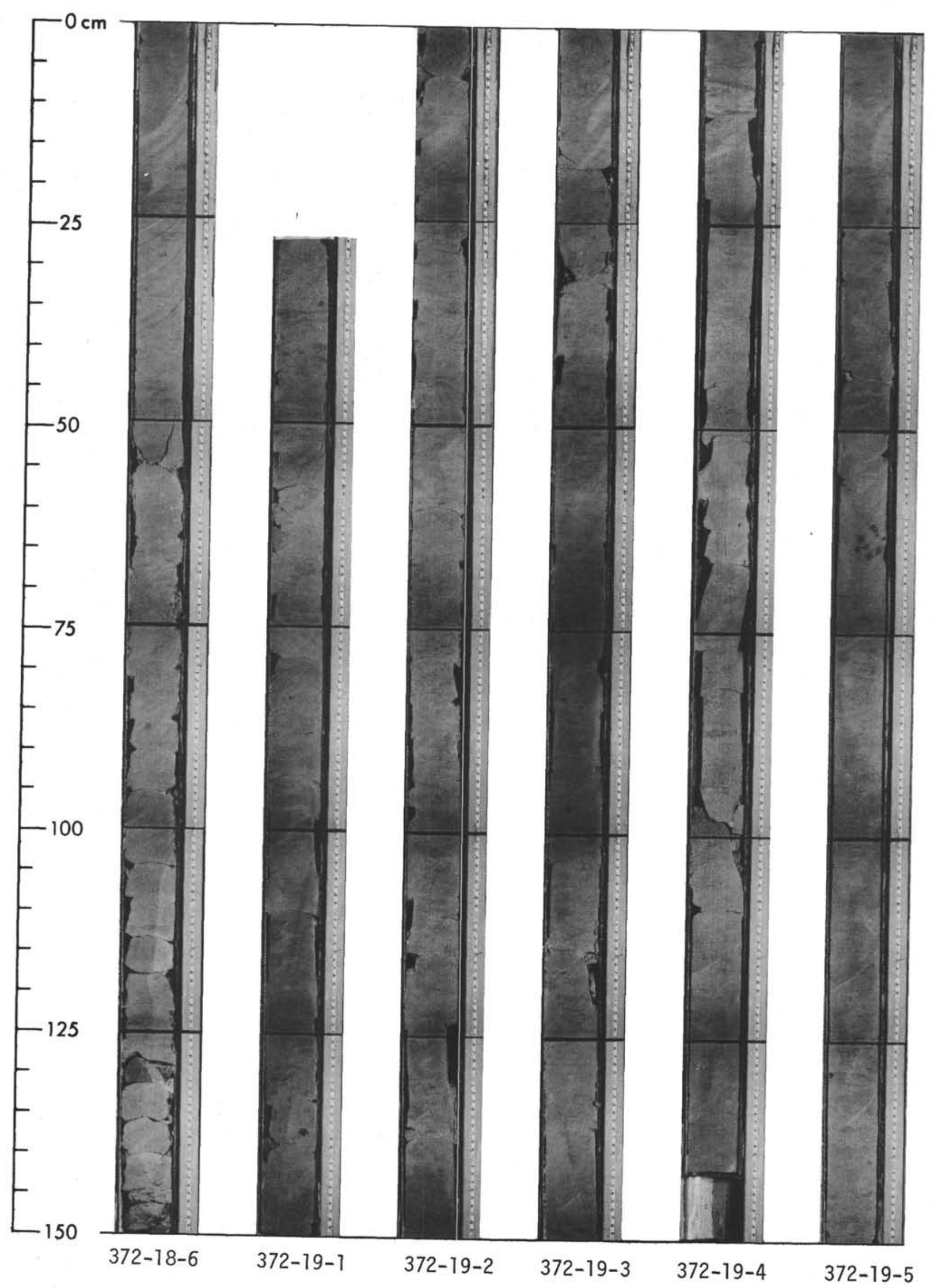


SITE 372: MENORCA RISE

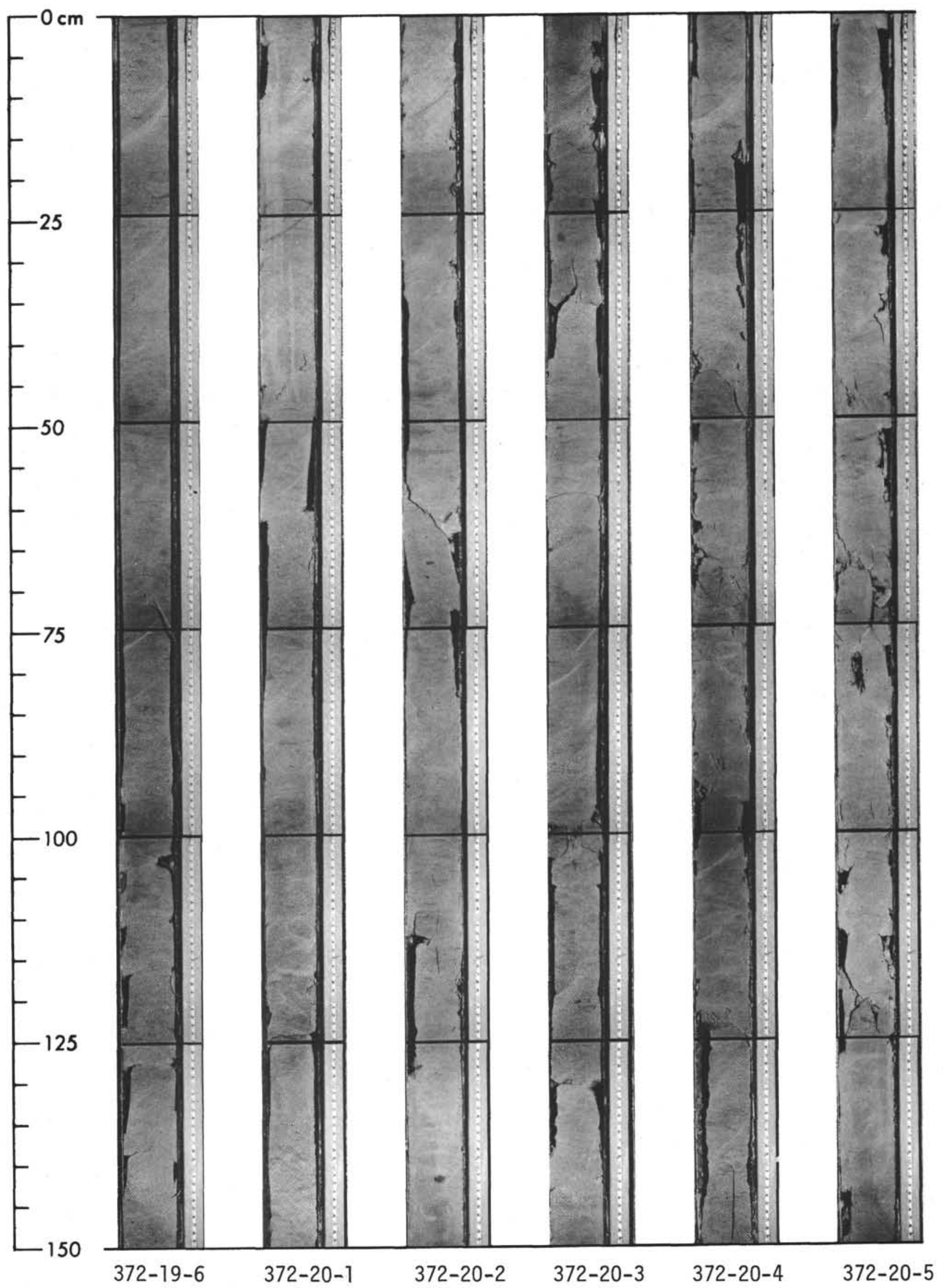


SITE 372: MENORCA RISE

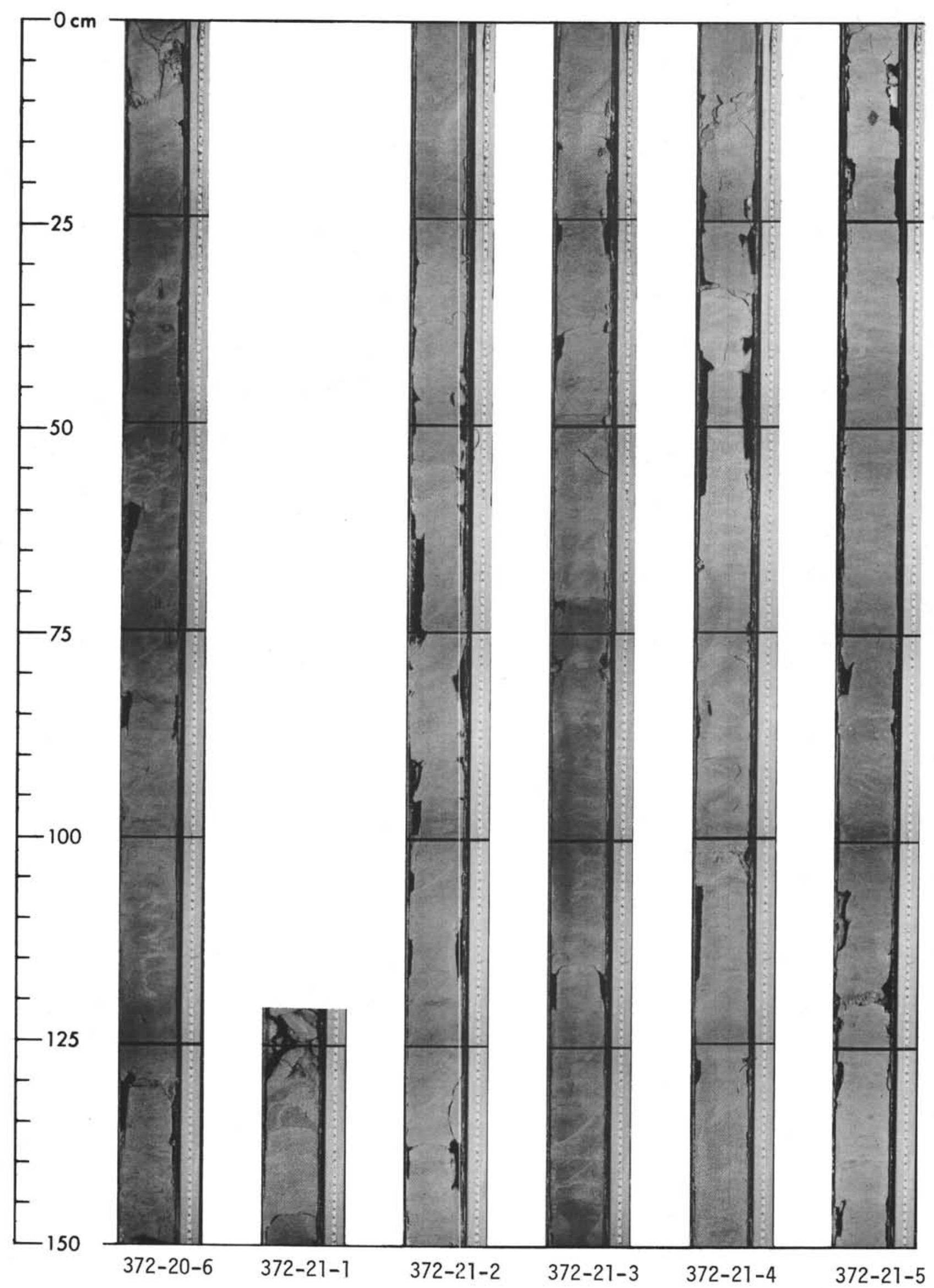




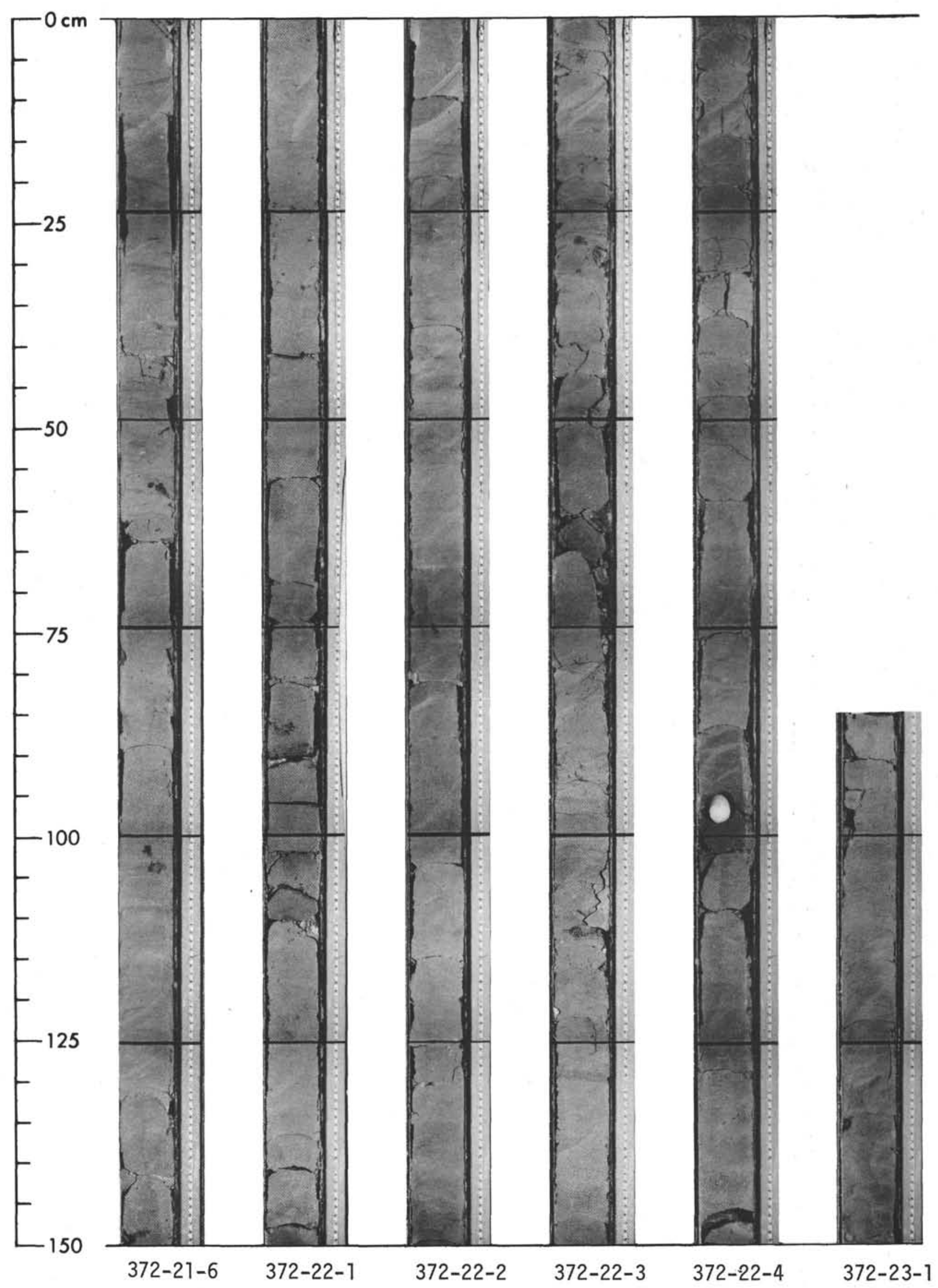




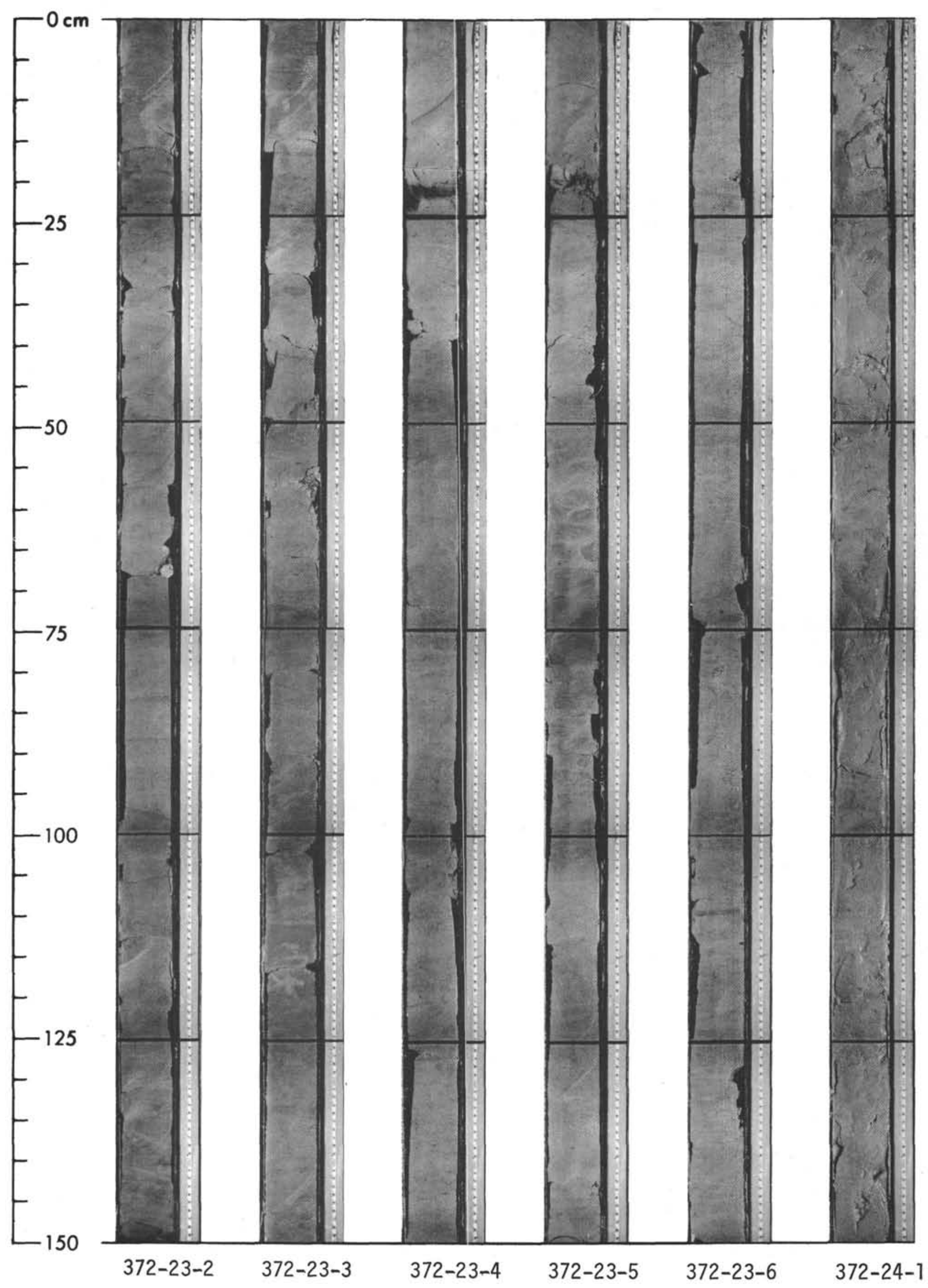




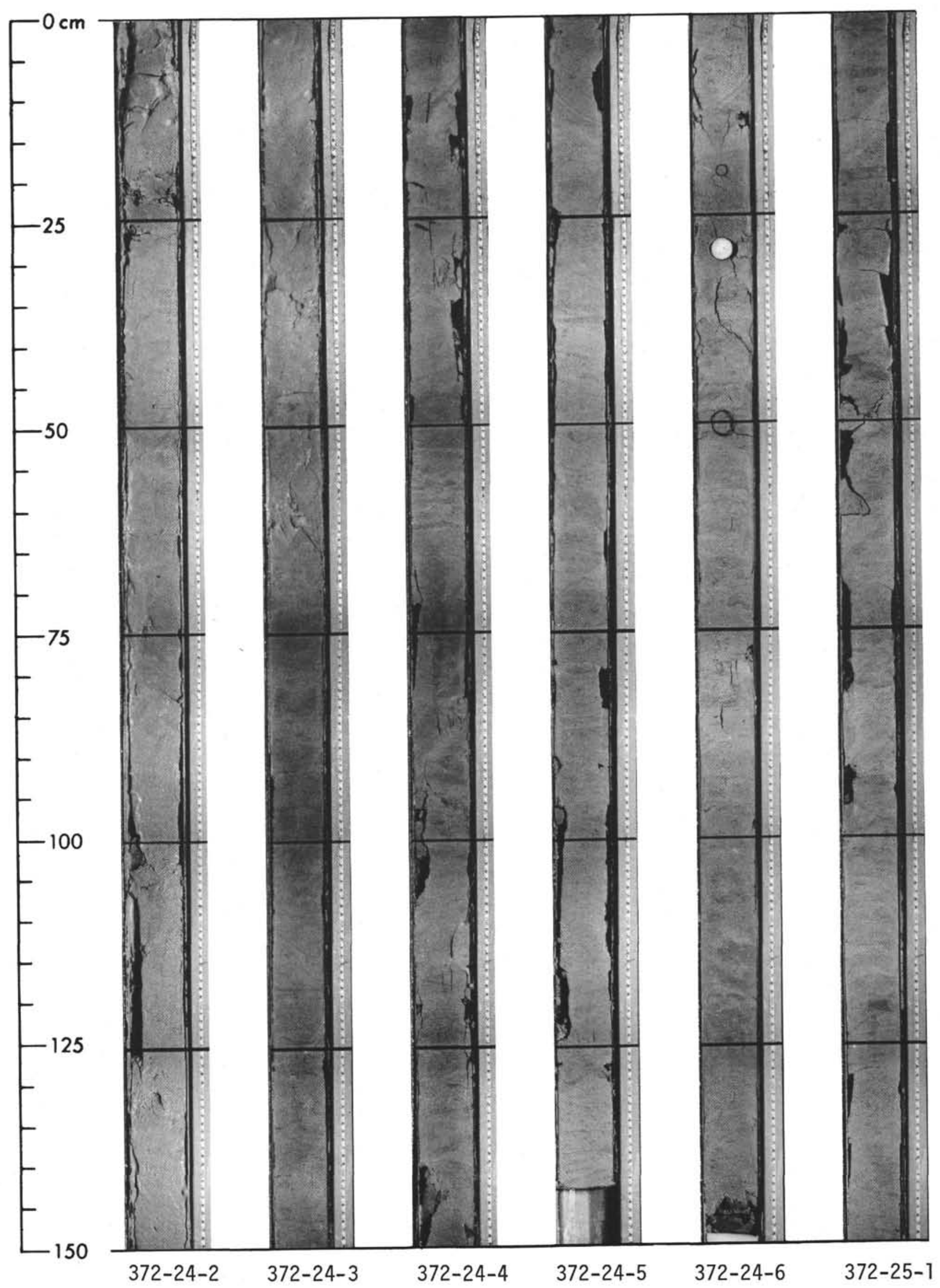




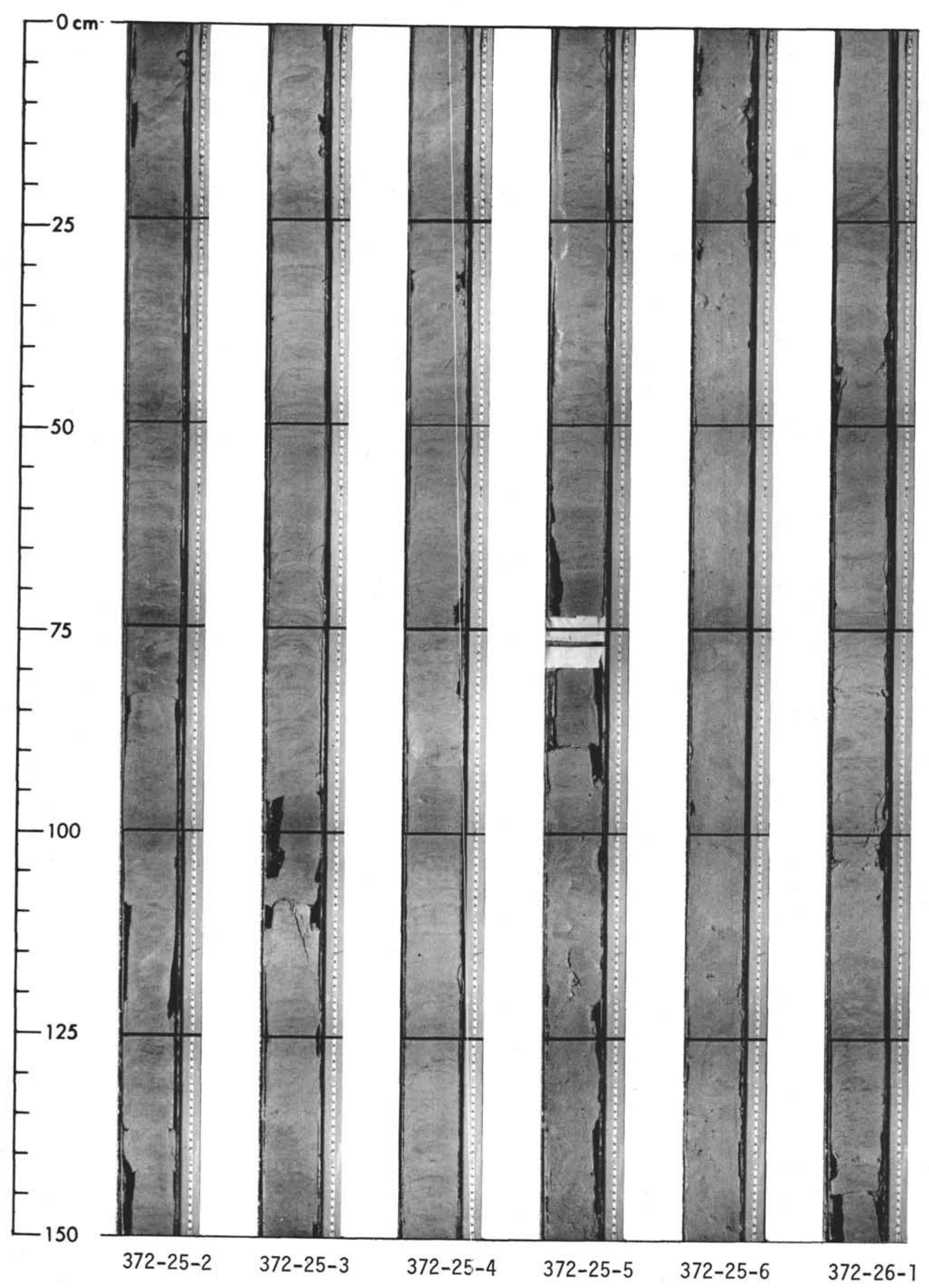




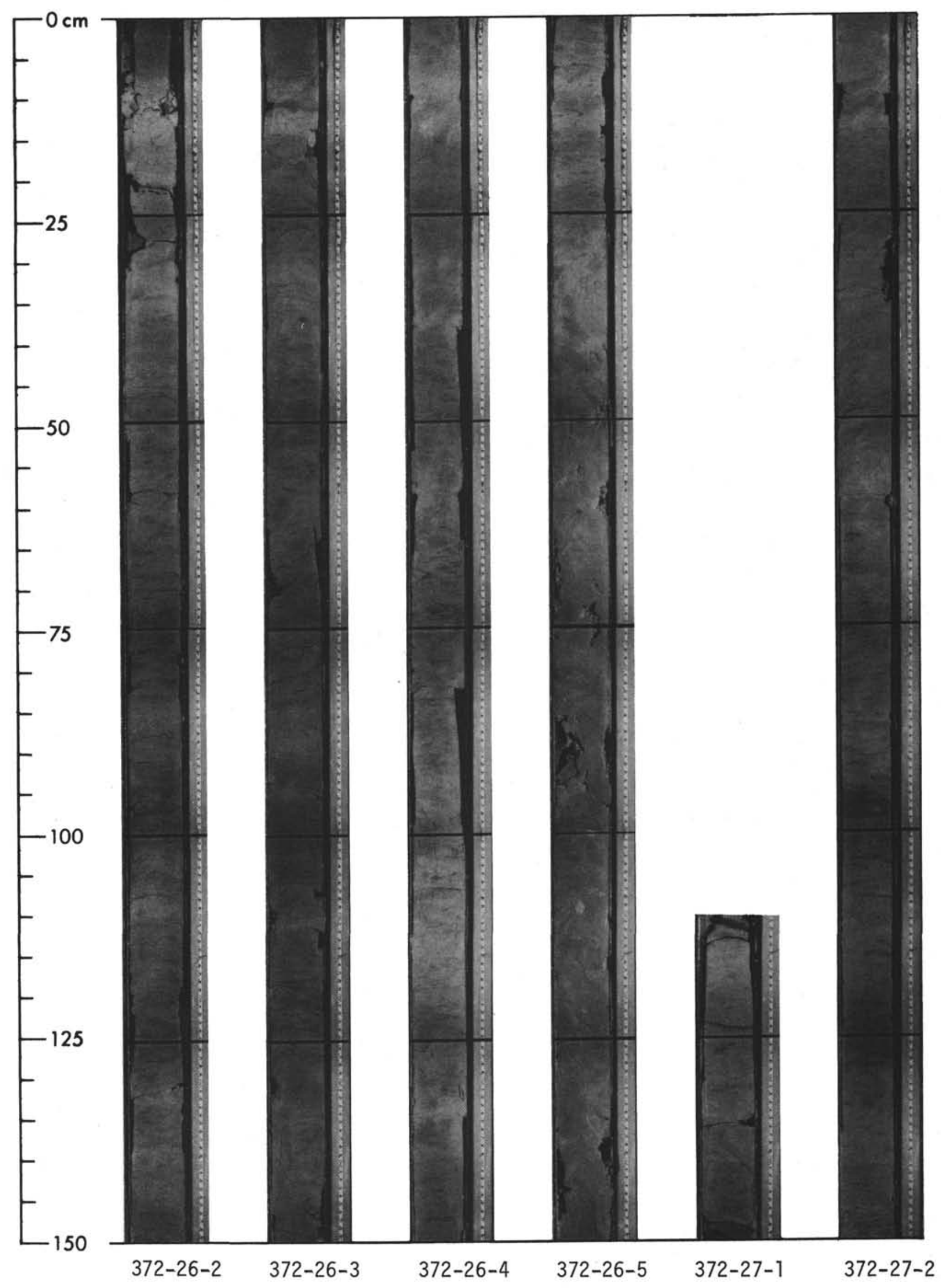




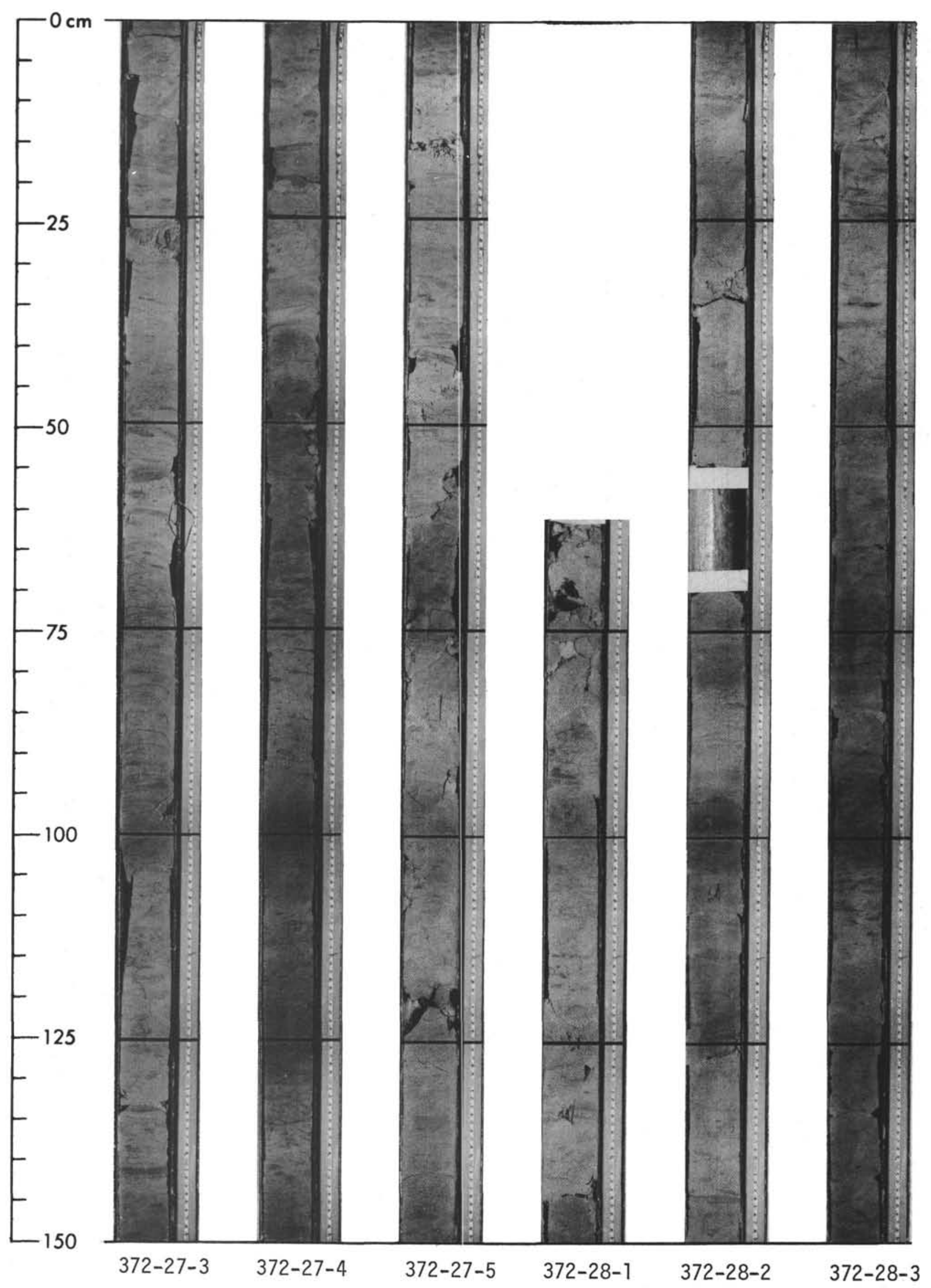




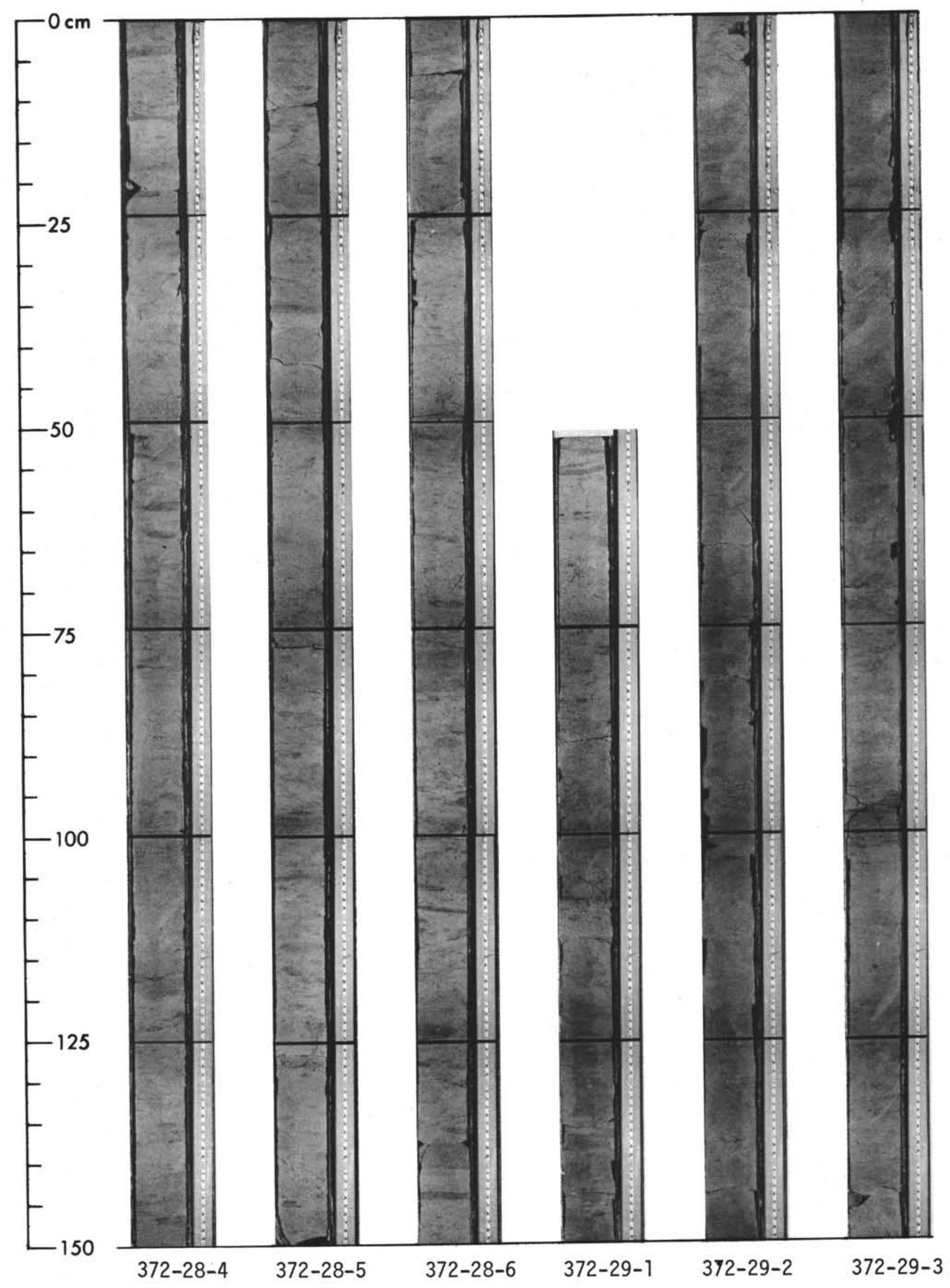




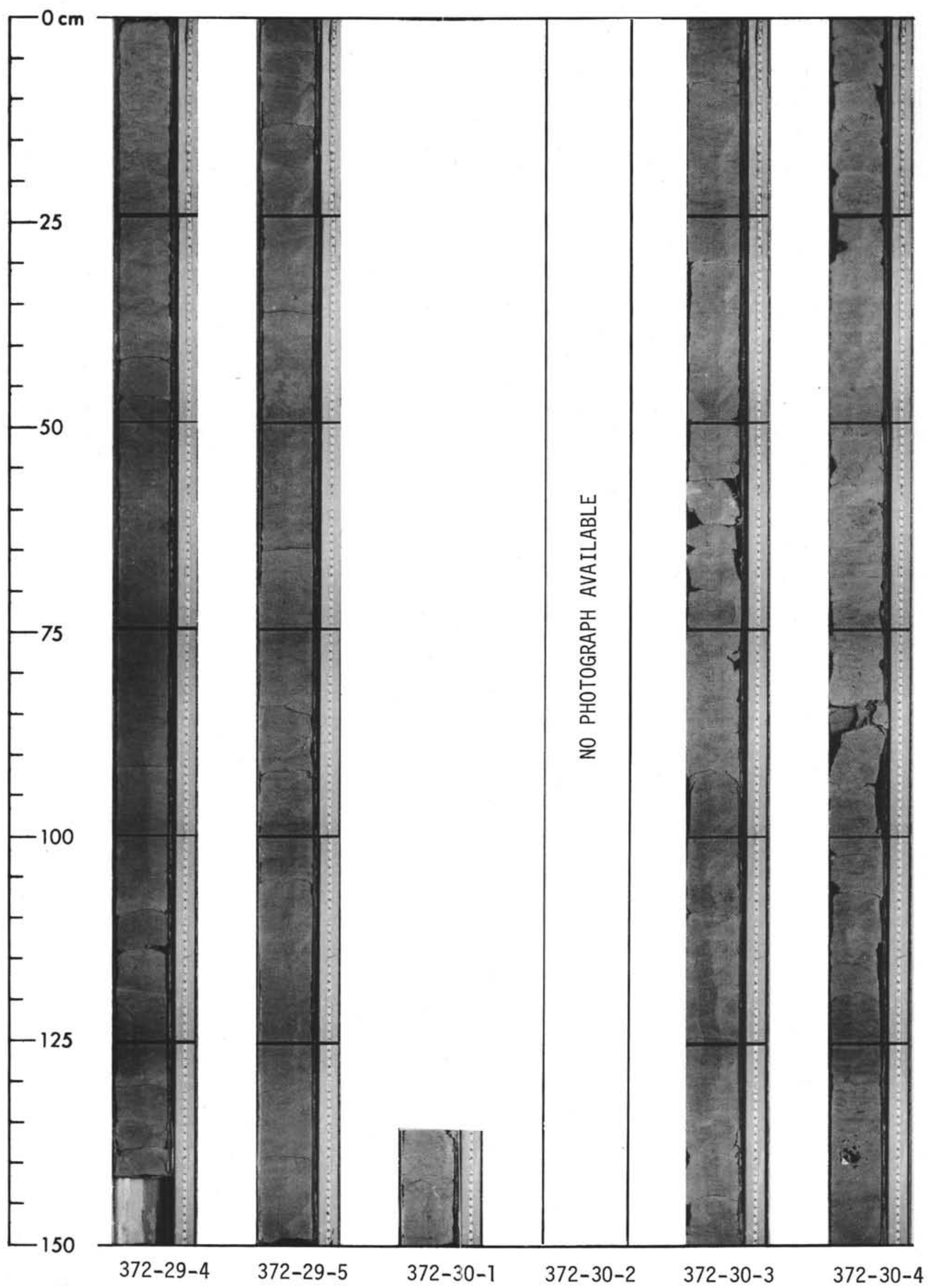




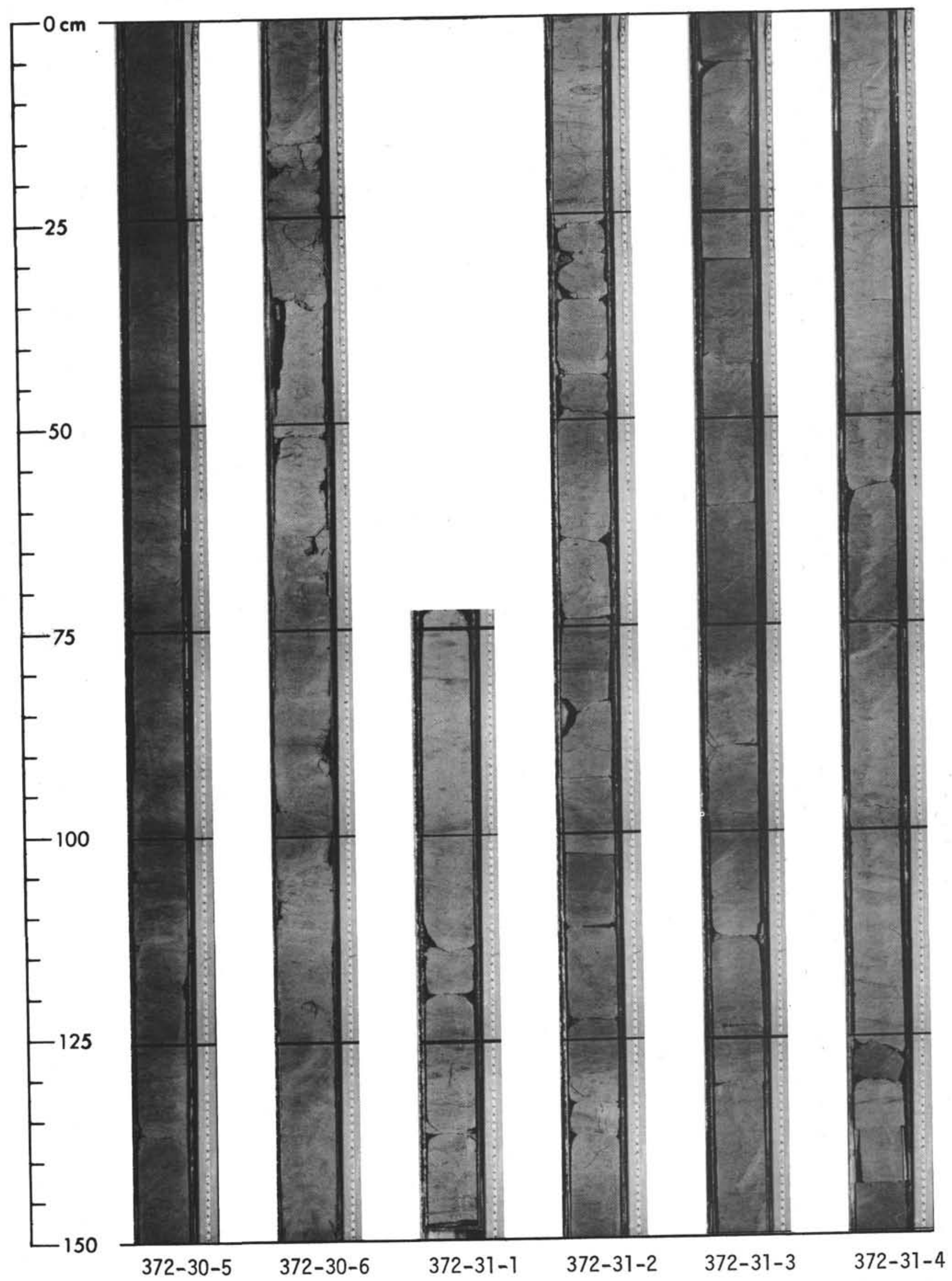




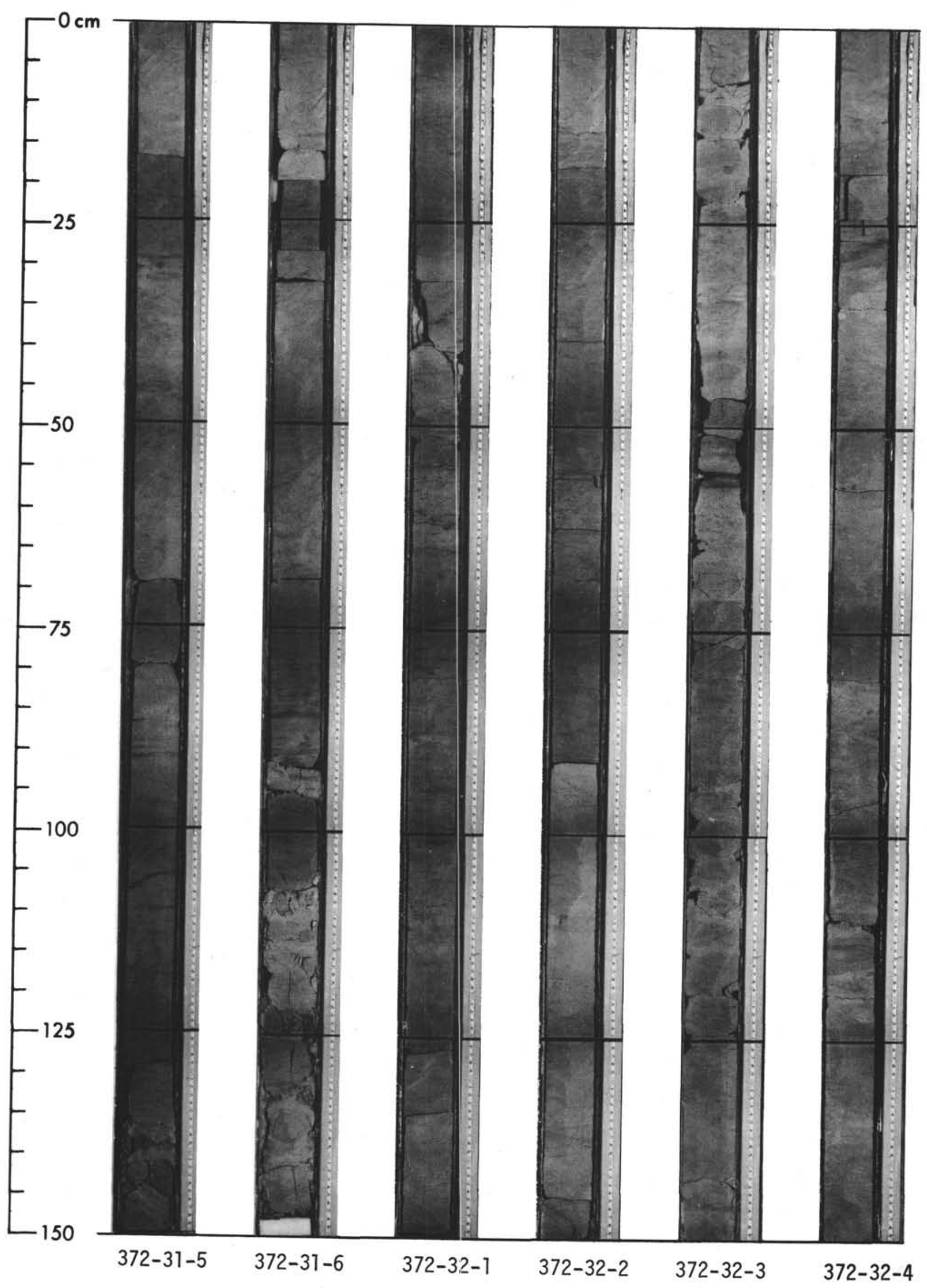


SITE 372: MENORCA RISE

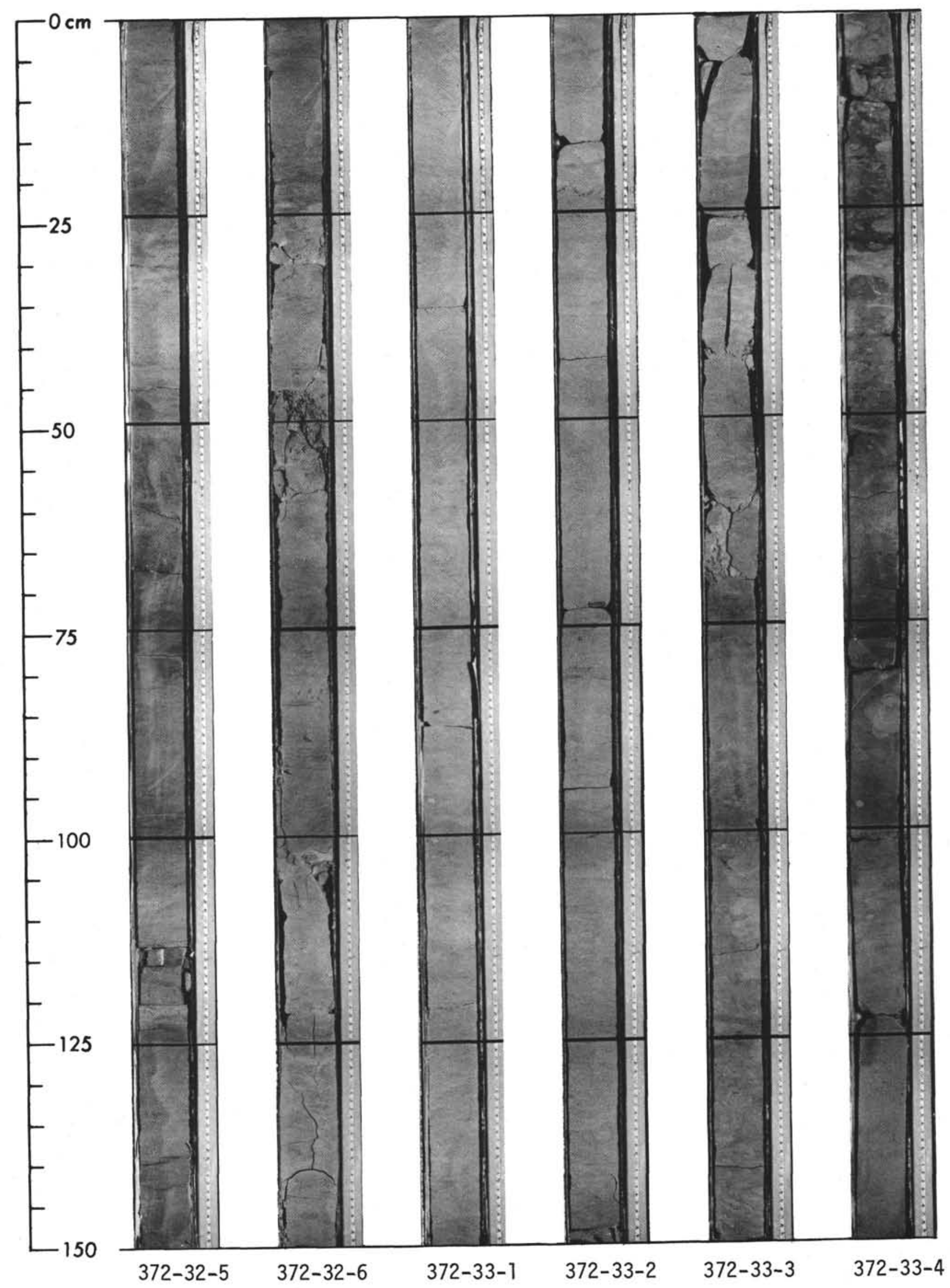




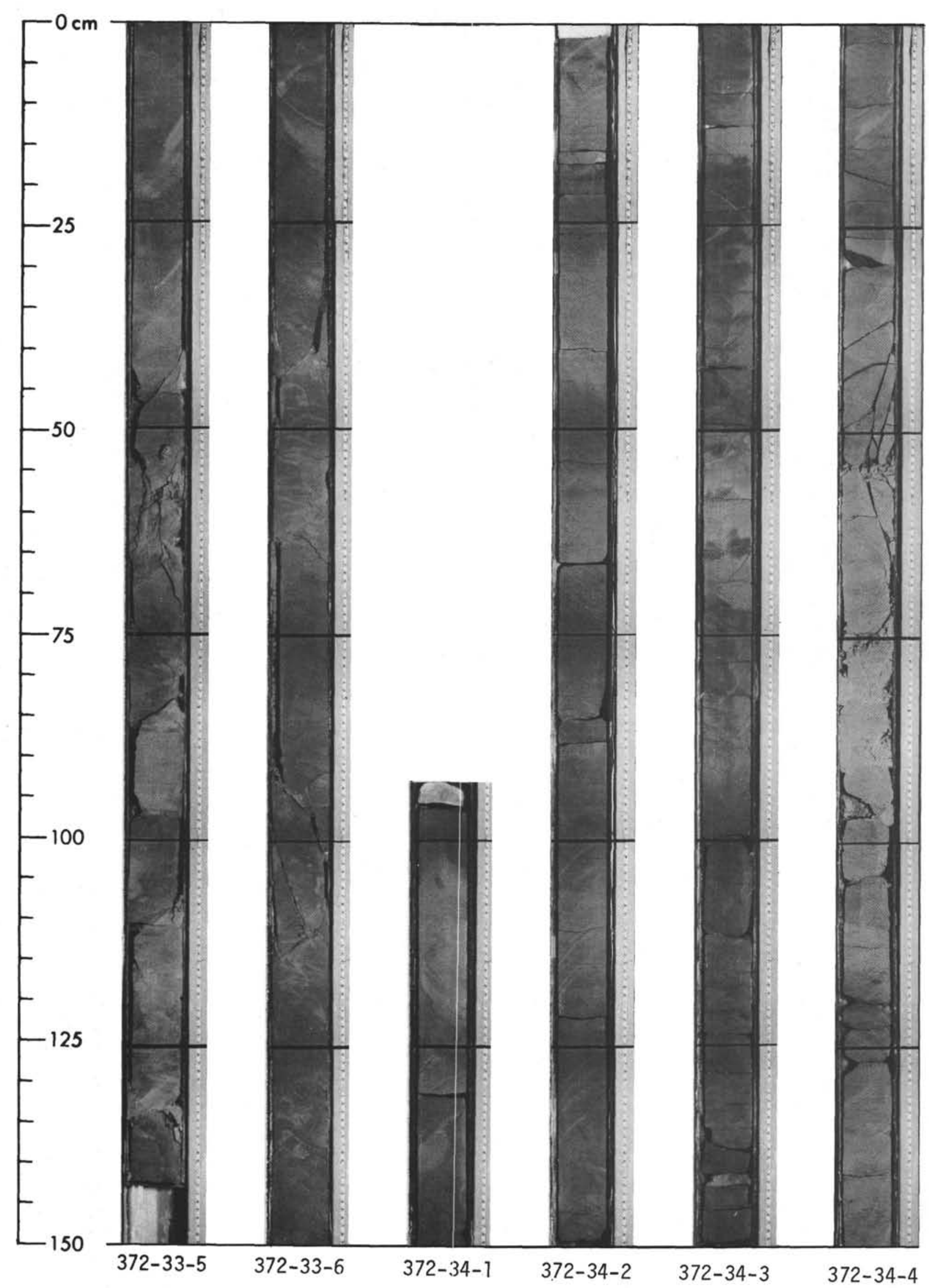


SITE 372: MENORCA RISE

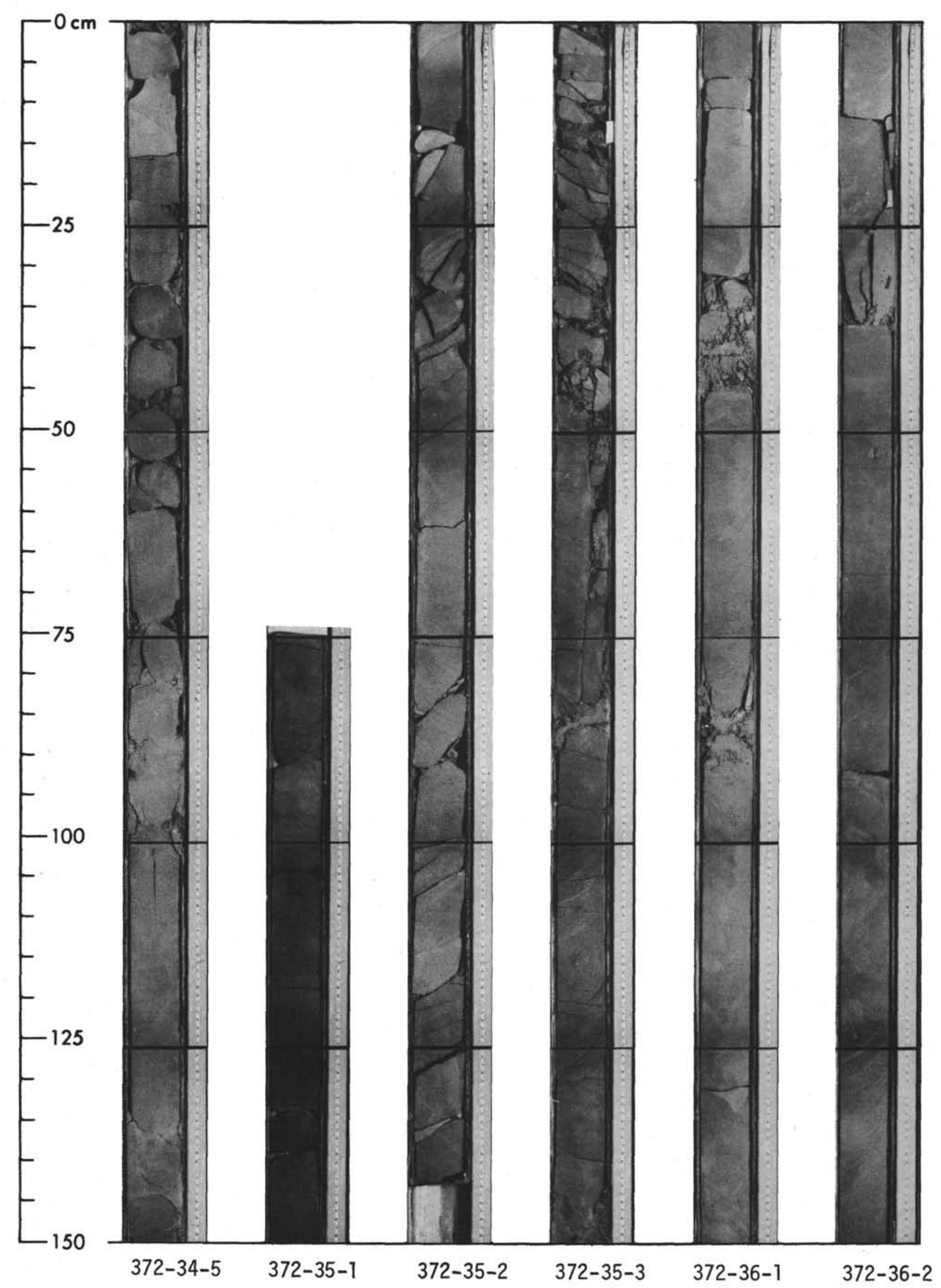




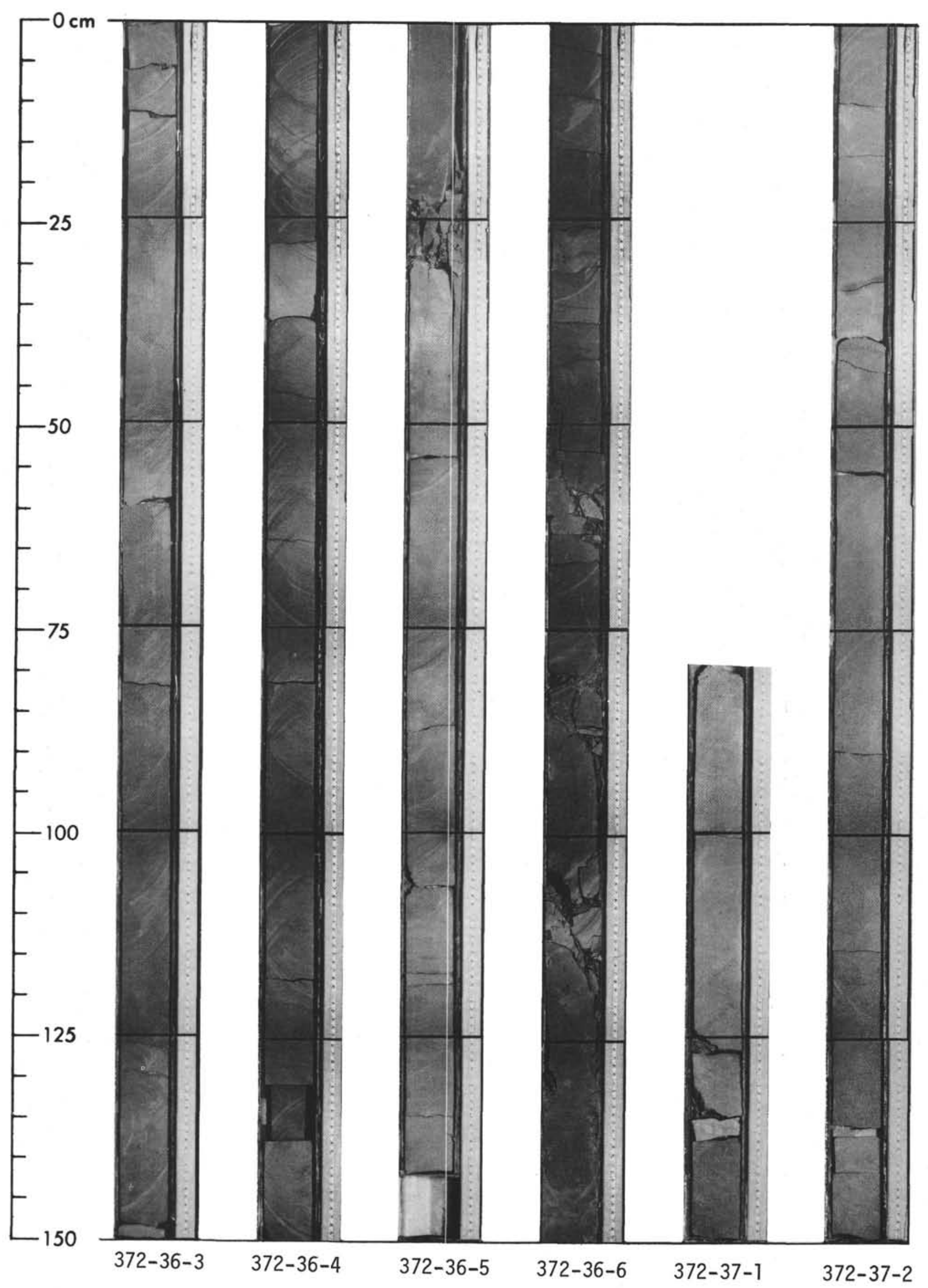




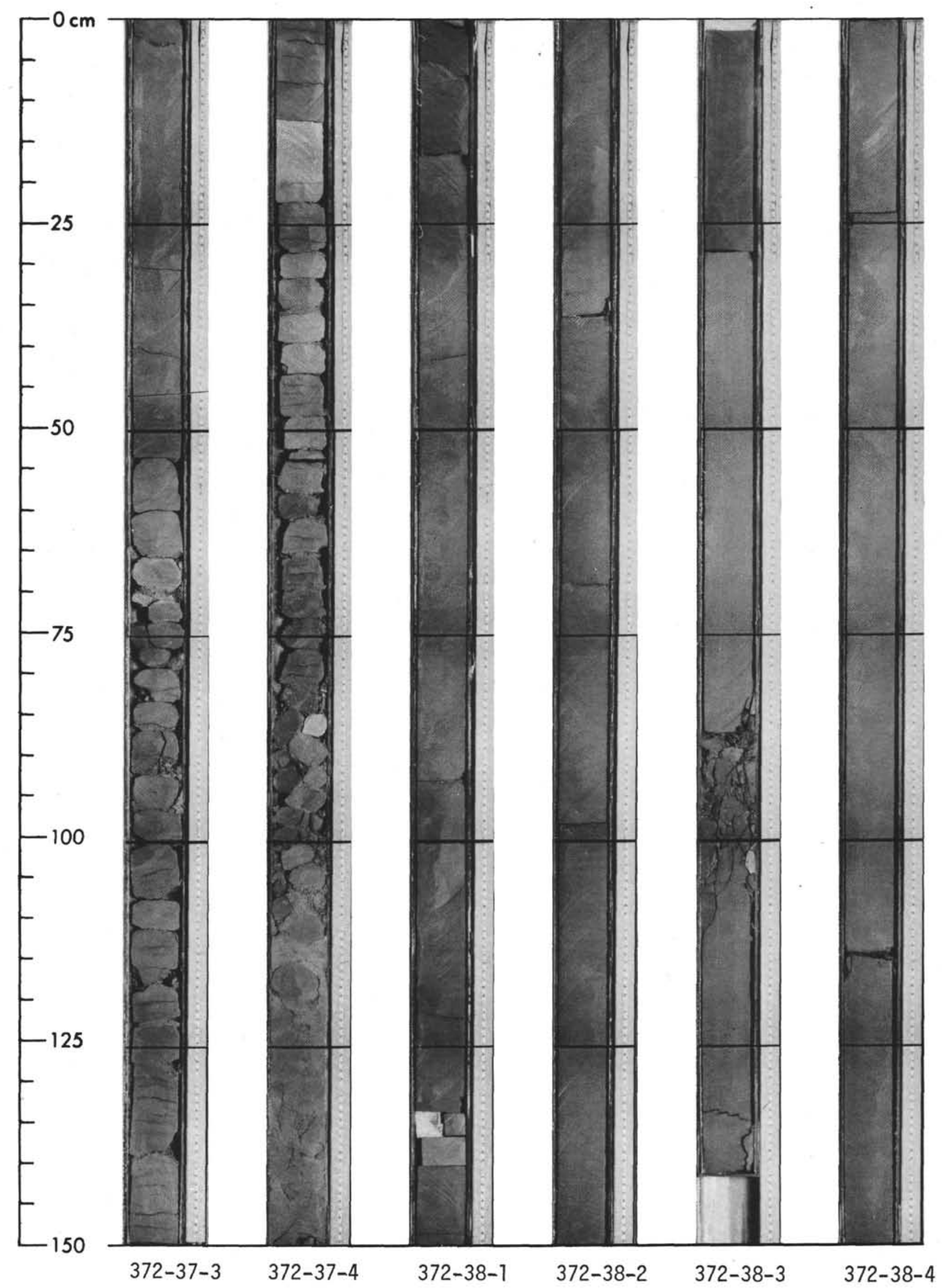




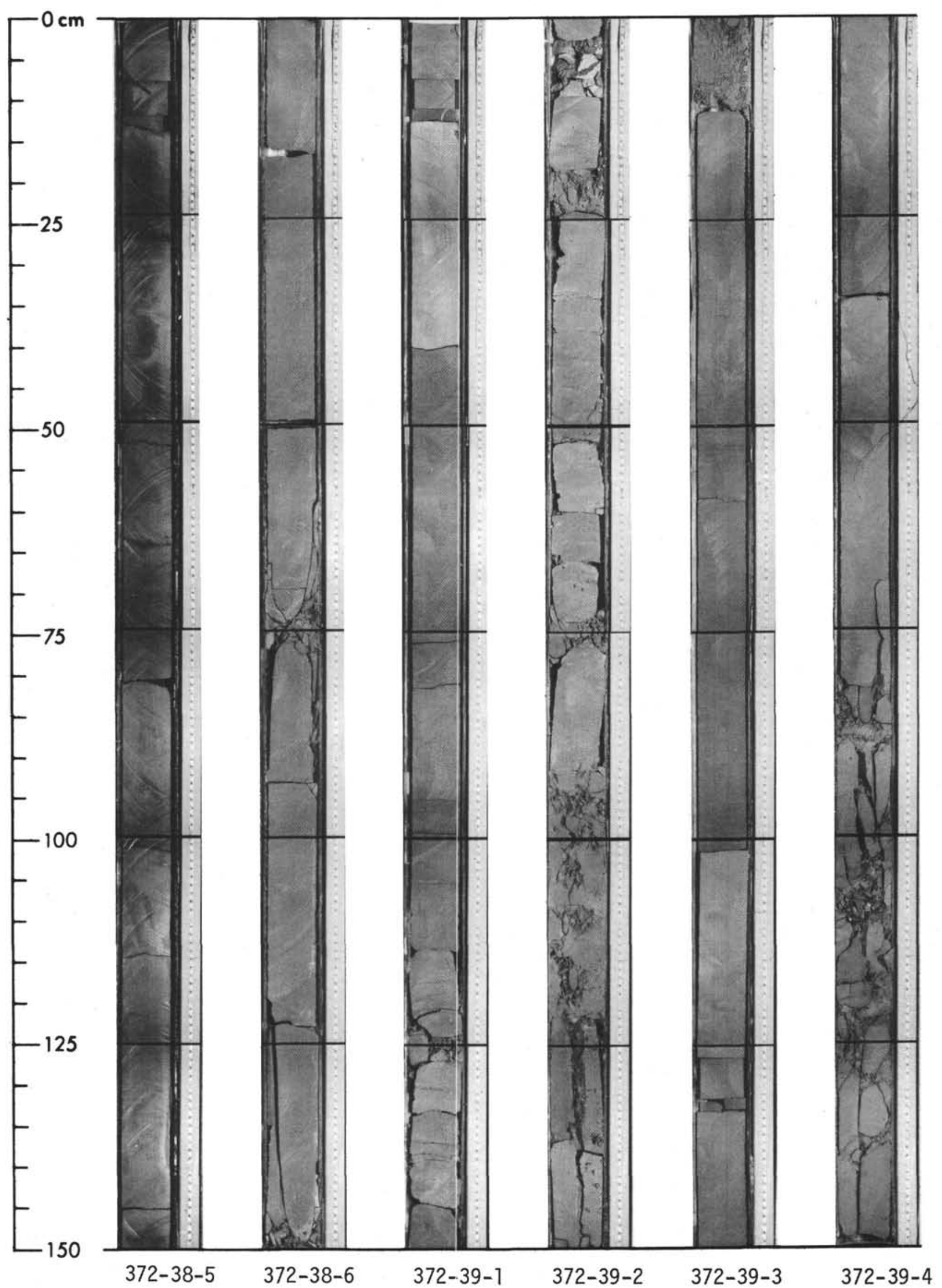




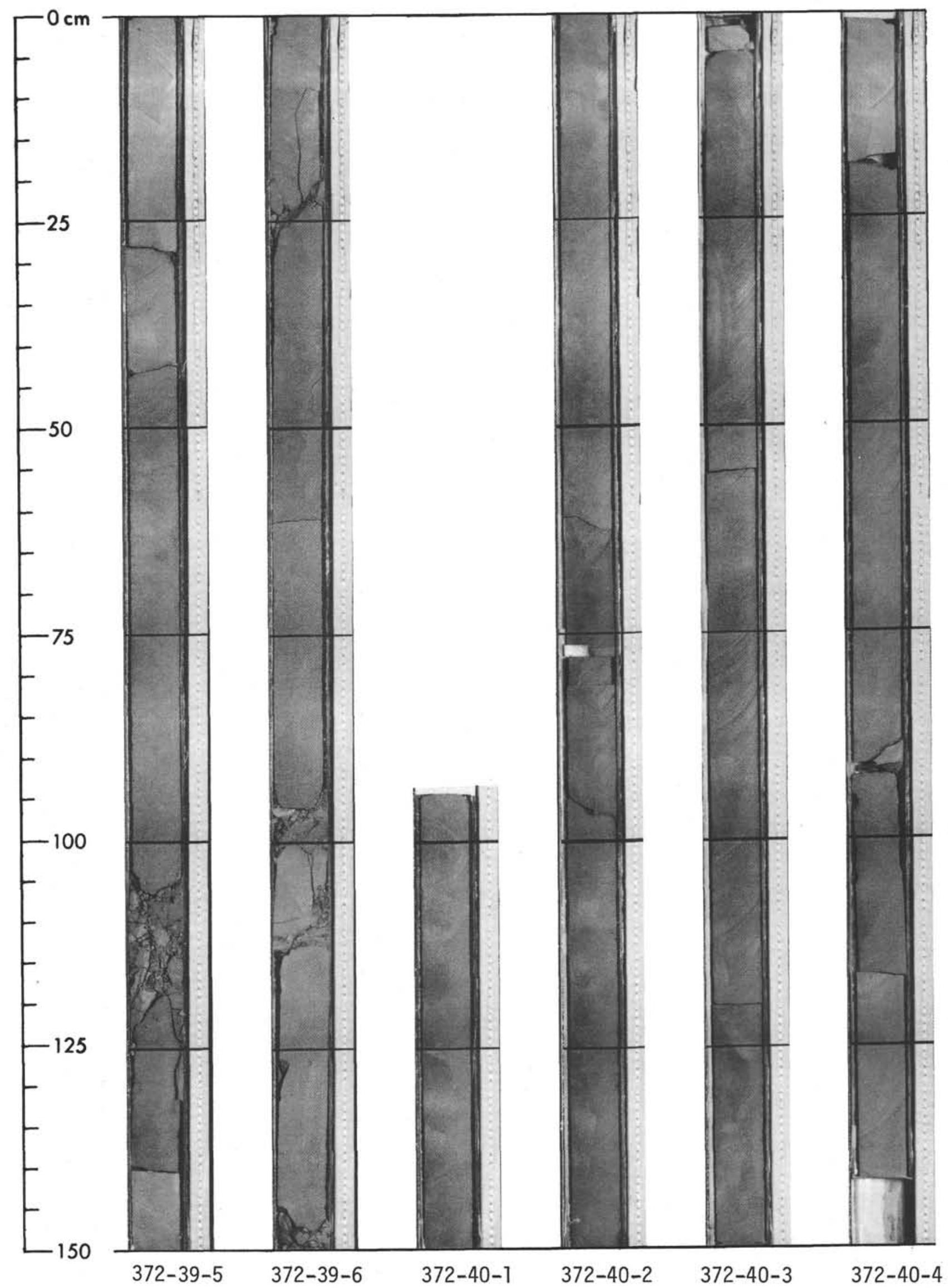




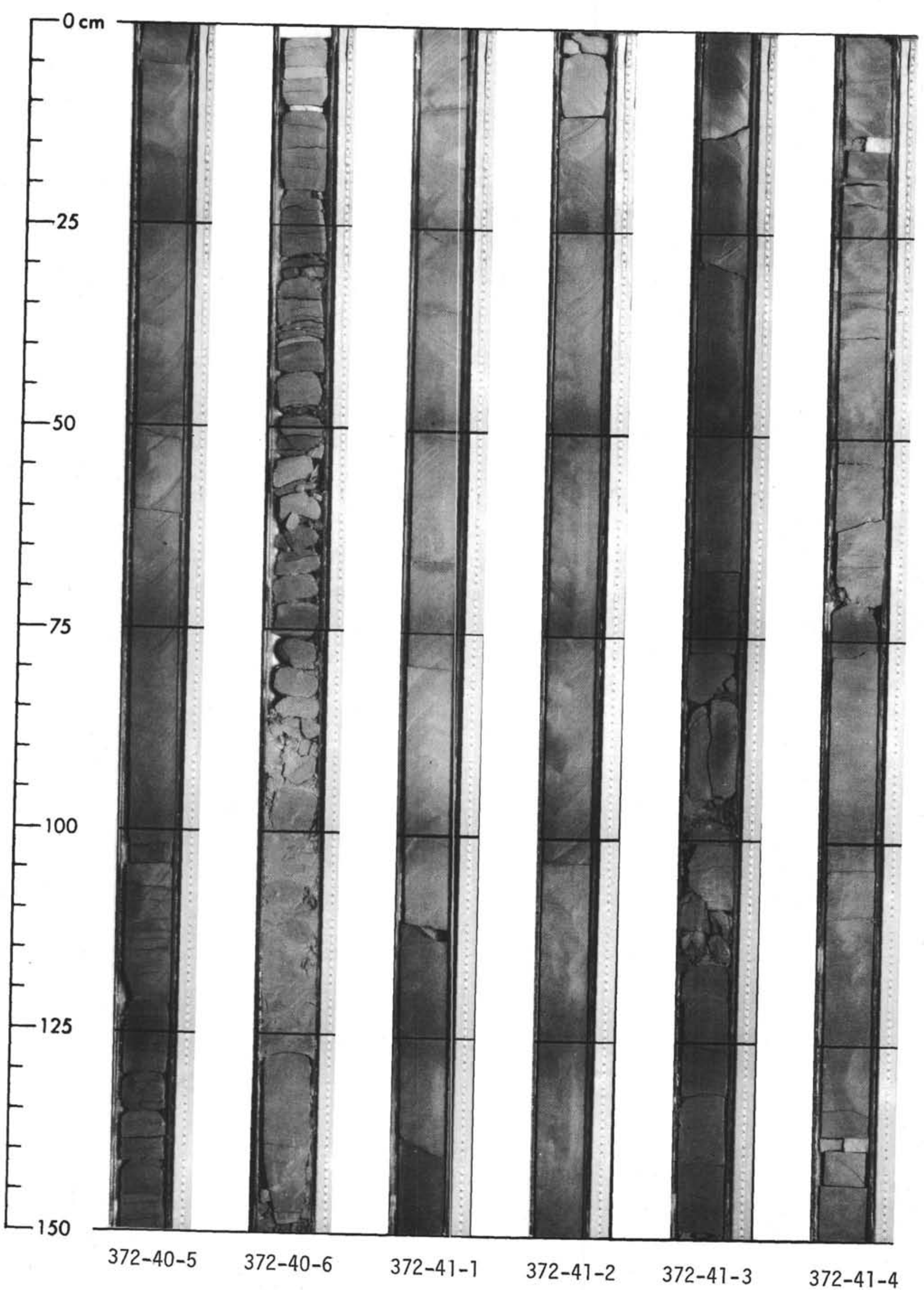




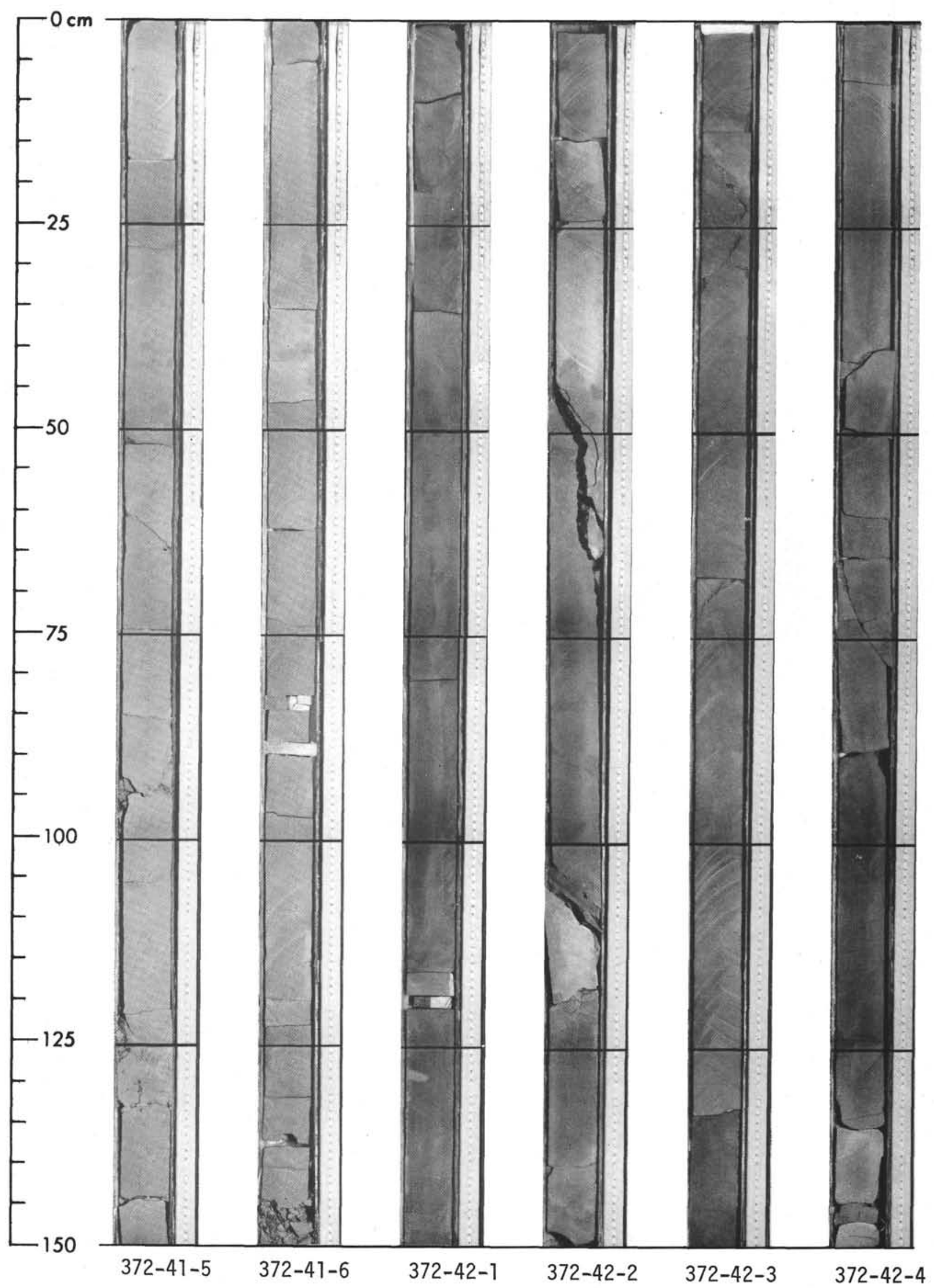


SITE 372: MENORCA RISE

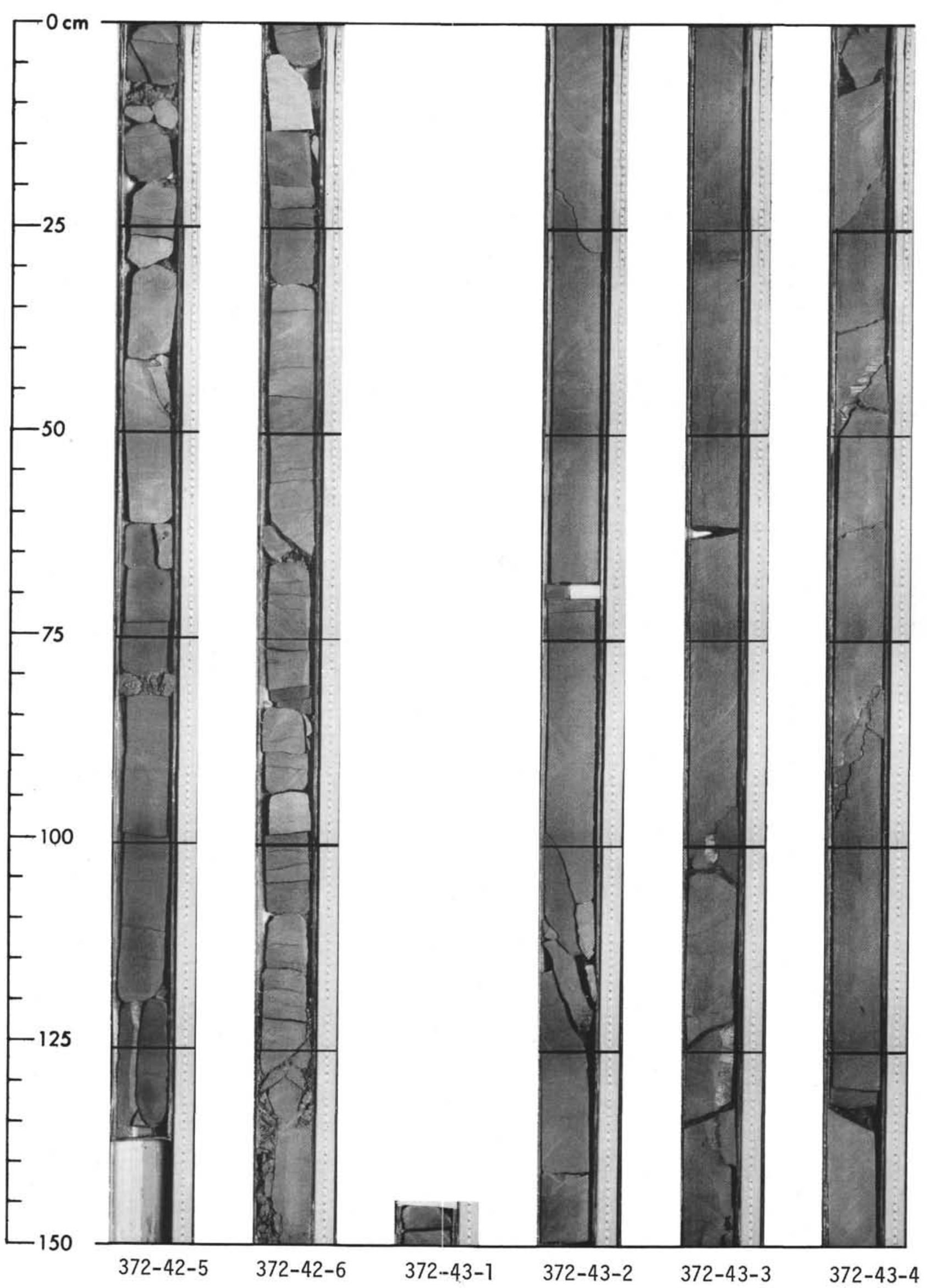




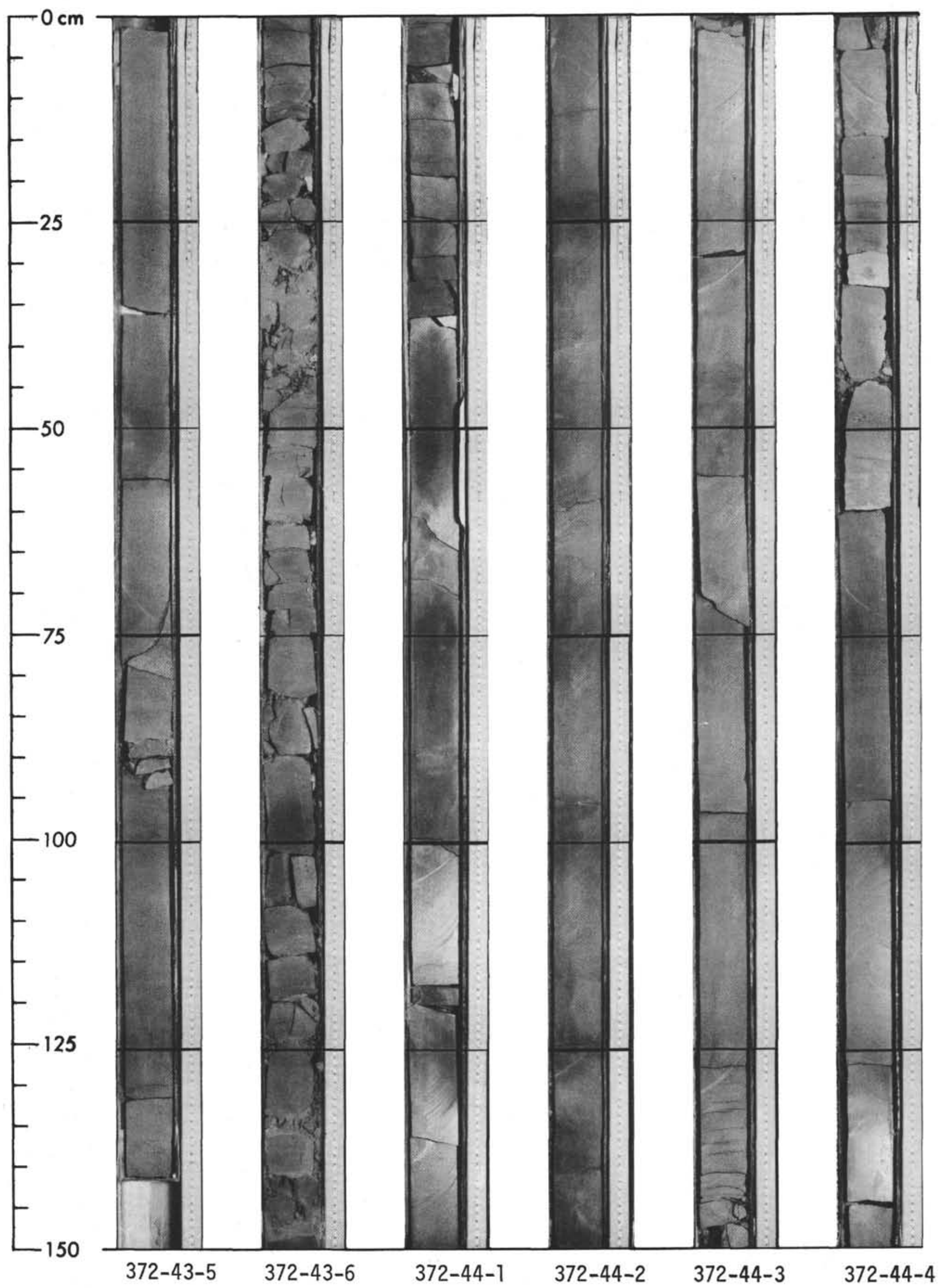




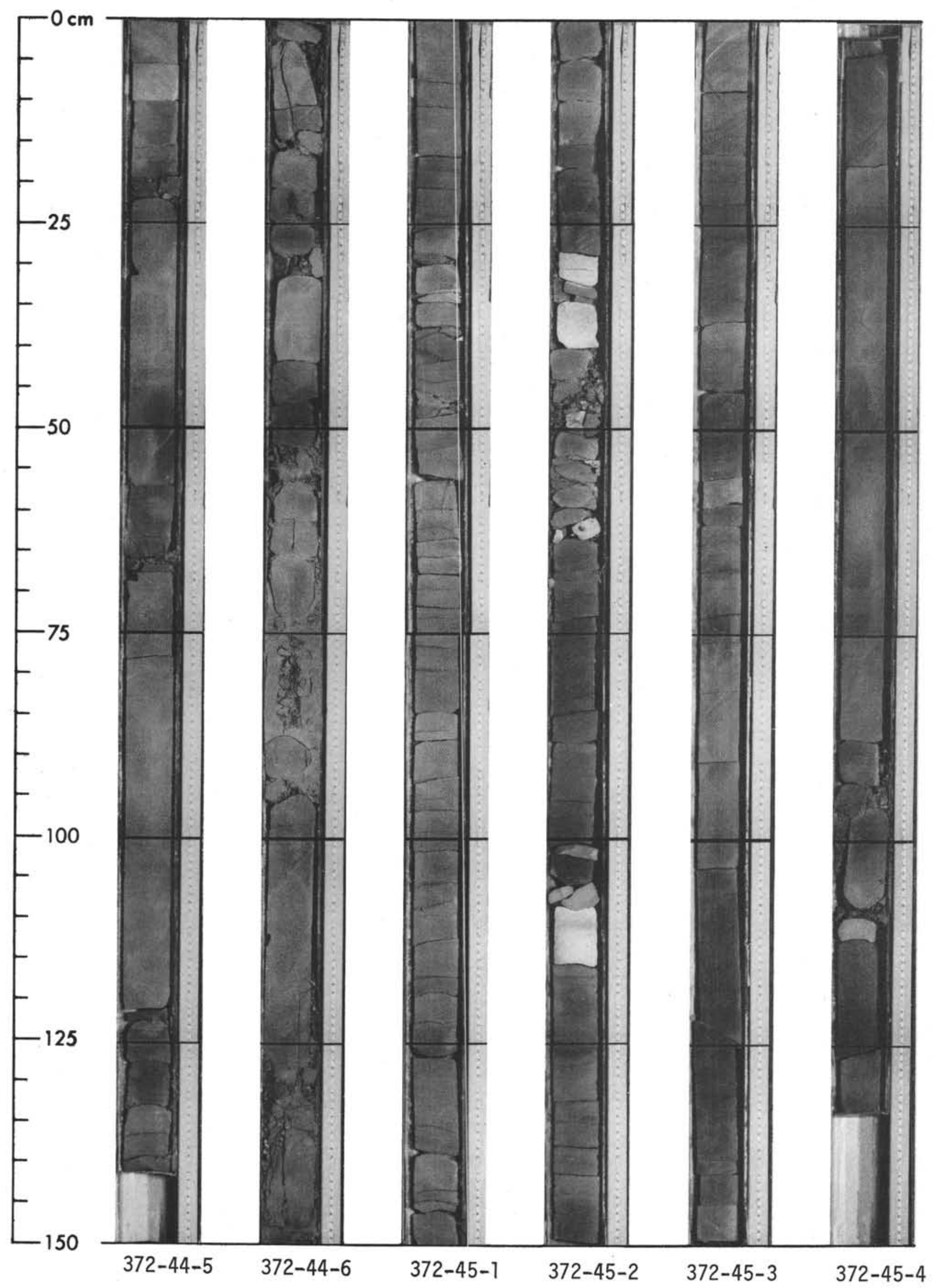




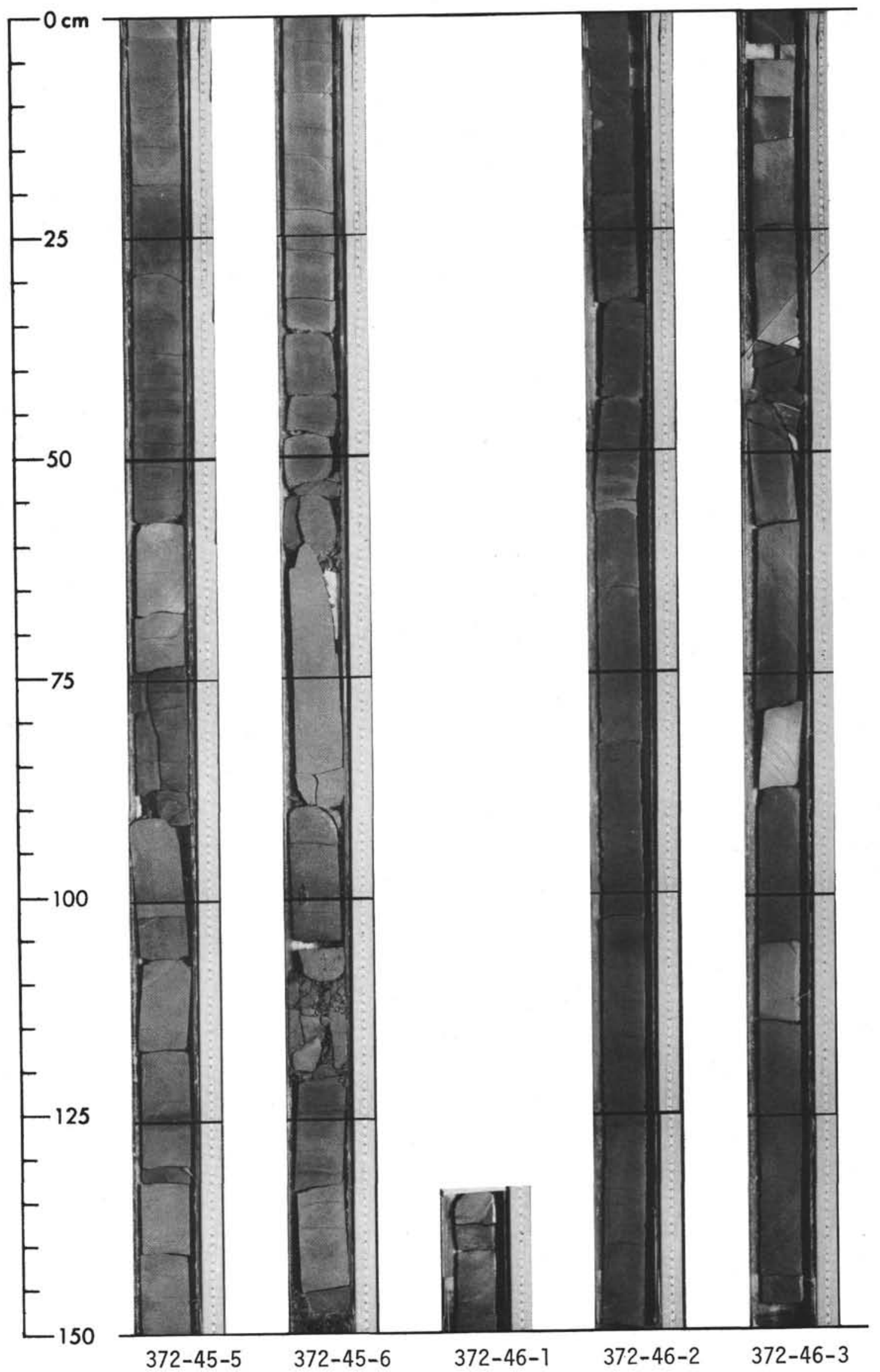

